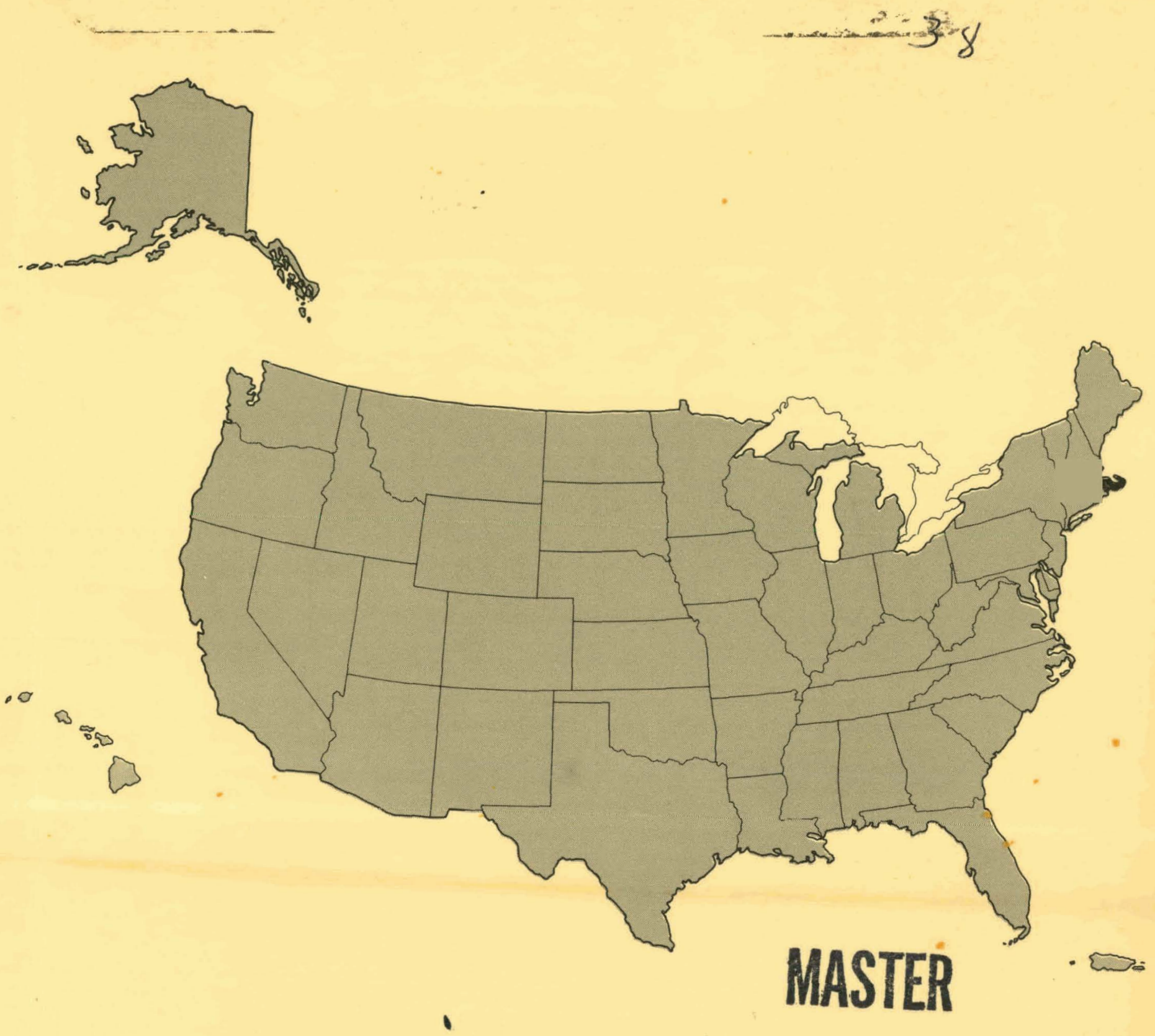

\title{
Massachusetts State Briefing Book for Low-Level Radioactive Waste Management
}




\section{DISCLAIMER}

This report was prepared as an account of work sponsored by an agency of the United States Government. Neither the United States Government nor any agency Thereof, nor any of their employees, makes any warranty, express or implied, or assumes any legal liability or responsibility for the accuracy, completeness, or usefulness of any information, apparatus, product, or process disclosed, or represents that its use would not infringe privately owned rights. Reference herein to any specific commercial product, process, or service by trade name, trademark, manufacturer, or otherwise does not necessarily constitute or imply its endorsement, recommendation, or favoring by the United States Government or any agency thereof. The views and opinions of authors expressed herein do not necessarily state or reflect those of the United States Government or any agency thereof. 


\section{DISCLAIMER}

Portions of this document may be illegible in electronic image products. Images are produced from the best available original document. 


\section{DOE/EN/O1570- T.38}

MASSACHUSETTS STATE BRIEFING BOOK FOR
LOW-LEVEL RADIOACTIVEFWASTE MANAGEMENT

DOE/ID/01570--T38

Prepared for

DE82 015249

EG\&G Idaho, Inc. under

Subcontract No. K-1959

Prepared by

Politech Corporation

2220 Austin National Bank Tower 515 Congress Avenue $\checkmark$ Austin, Texas 78701

This report was prepared as a summary of work sponsored by the United States Government. Neither the United States nor the United States Department of Energy, nor any of their employees, nor any of their contractors, subcontractors, or their employees, make any warranty, express or implied, or assumes any legal. liability or responsibility for the accuracy, completeness, or usefulness of any information, product, or process disclosed, or represents that its use would not infringe privately owned rights.

March 12, 1981

1צי.

\section{NOTICE}

PORTIONS OF THIS REPORT ARE IILLEGIBLE. IF

has been reproduced from the best availabla

copy to permit the broadest possible avail-

ability. 
CONTENTS

TITLE PAGE . . . . . . . . . . . . . . . . . . . i LIST OF MAPS . . . . . . . . . . . . . . . . . . . iv LIST OF FIGURES . . . . . . . . . . . . . . . . . v v LIST OF TABLES ....................... vi FOREWORD . . . . . . . . . . . . . . . . . . . . . vii

SECTION 1: INTRODUCTION .................. 1-1

SECTION 2: OVERVIEW OF LOW-LEVEL RADIOACTIVE WASTE

MANAGEMENT IN MASSACHUSETTS

Nuclear Regulatory Commission Licensees . . . . . 2-1

Current Disposal Practices . . . . . . . . 2-1

Regulatory Enforcement . . . . . . . . . . 2-2

SECTION 3: DEMOGRAPHY

3.1 Population and Location . . . . . . . 3-2

3.2 Government . . . . . . . . . . 3-11

3.3 Agriculture ................ 3-18

3.4 The Economy ............... 3-20

3.5 Health ................ . 3-32

3.6 Higher Education ............... 34

SECTION 4: GOVERNMENTAL AND PUBLIC ASPECTS

4.1 Major Political Parties ... . . . . . . 4-1

4.2 The Massachusetts Delegation ....... 4-1

4.3 State Government ........... 4-4

4.3a Executive Branch ........... 4-4

4.3b Legislative Branch ......... 4-12 
4.3c Judicial Branch .......... . 4-31

4.3d Relevant Statutes and Regulations ... 4-32

4.4 Federal Activities in the State of

Massachusetts . . . . . . . . 4-37

4.5 Iocal Government Authority ........ . 4-37

4.6 Citizen Action ............. 4-38

4.7 Printed Media............. 4-45

SECTION 5: SURVEY METHODOLOGY

Overview . . . . . . . . . . . 5-2

Exhibit I . . . . . . . . . . . . . 5-4

Exhibit II . . . . . . . . . . . . . 5-7

Exhibit III ................. . . 5-8

SECTION 6: MASSACHUSETTS RADIOACTIVE WASTE SURVEY

Use of Commercial Low-Level Waste Disposal

Facilities . . . . . . . . . . . . 6-1

Response to Survey . . . . . . . . . . 6-1

Origin and Distribution of Shipped Waste..... . 6-2

Volume of Shipped Waste ........... . 6-2

Activity of Shipped Waste .......... 6-3

Physical Characteristics of Shipped Waste ... . 6-3

APPENDICES :

A. RADIOACTIVE LICENSEES IN THE STATE OF MASSACHUSETTS

B. "LOW-LEVEL RADIOACTIVE WASTE MANAGEMENT IN MASSACHUSETTS." A REPORT TO THE GOVERNOR OF MASSACHUSETIS BY THE MASSACHUSETTS ADVISORY COUNCIL ON RADIATION PROTECTION.

C. REGULATIONS PERTAINING TO RADIOACTIVE WASTE MANAGFMENT IN : MASSACHUSETTS

D. ROSTER OF DAILY NEWSPAPERS IN MASSACHUSETTS 


\section{List of Maps}

Map

Page

3.1 Massachusetts' State Economic Areas (SEAs) ..... 3-3

3.2 Rates of Population Growth, 1970-78 ....... 3-13

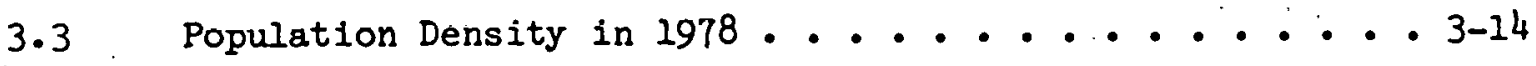

4.1 Massachusetts' Congressional Districts ....... 4-14 


\section{List of Figures}

Figure(s)

1.1

United States Low-Level Waste Commercial

Disposal ................. . 1-3

1.2 Volumes and Radioactivity of Low-Level Waste (U.S.). . 1-5

3.1-3.1.3 Population Bar Graphs, Massachusetts State

Economic Areas (1978) ......... 3-5 


\section{List of Tables}

Table(s)

$\underline{\text { Page }}$

1.1 Low-Level Waste Distribution by State, 1979 . . . 1-4

3.1 Demographic Growth and Density Information . . - 3-12

3.2 Government Employment and Payroll Data . . . . 3-16

3.3 Government Finance Data . . . . . . . . 3-17

3.4 Agricultural Data . . . . . . . . 3-19

3.5.1-3.5.3 Economic Data by SEA (1974 and 1978) . . . . 3-21

3.6 Change in Payrolls Between 1974-1978 . . . . 3-30

3.7 Health Information (1975) . . . . . 3-33

3.9 Information on Institutions of Higher

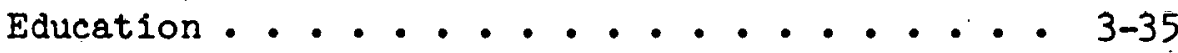

4.1 Legislative Information Services . . . . . 4-13.

6.1-6.11 Radioactive Waste Survey Summary Tables . . . . 6-4 
FOREWORD

The information contained in this state briefing book for lowlevel waste management was compiled from several sources. Information about the structure, organization, and jurisdiction of state and local governments; statutory and regulatory requirements; news media; and interested parties was obtained principally through on-site interviews with state officials and printed materials gathered during the state capitol visits.

In addition, other materials previously prepared for EG\&G Idaho, Inc. in support of the National Low-Level Radioactive Waste Management Program have been incorporated into this volume. Specifically, the project conducted for EG\&G is The 1979 State-by-State Assessment of LowLevel Radioactive Wastes Shipped to Commercial Burial Grounds, prepared by NUS Corporation. in November, 1980. Some materials and tables contained in this state handbook have been excerpted verbatim from that project. 
INTRODUCTION

The U.S. Department of Energy (DOE) is the lead federal agency in the area of commercial low-level radioactive waste management. The policy of state responsibility for commercial low-level waste disposal is not only DOE's policy, but is now formalized in federal law through the passage of the "Low-Level Radioactive Waste Policy Act," P.L. 96-573, in December, 1980. Several national groups and organizations, including the State Planning Council, the National Governors' Association, and the National Conference of State Legislatures, have endorsed this position on state responsibility as well as the concept that states be allowed to enter into regional compacts to meet their responsibilities for disposal of low-level wastes.

Radioactive wastes are produced whenever radioactive materials are processed or used. Few general statements can be made about the composition of these wastes since this depends on the source. A my riad of industrial, medical, and institutional activities generate low-level waste of various types. Wastes are characteristic of the process from which they originate and may occur in a gaseous, airborne particulate, liquid, or solid form.

Since low-level wastes contain less than 10 nanocuries per gram of transuranic (TRU) contaminants or may be totally free of the TRU contaminants, most require little or no shielding and have low, but potentially hazardous concentrations or quantities of radionuclides. The hazards posed by low-level wastes require that they be adequately isolated from direct routes of radiation exposure to humans (i.e., drinking water and $a i r$ ) as well as the indirect routes (i.e., plants and animals eaten). In the case of most low-level wastes, this can be accomplished by shallow land burial. 
To date, approximately 2.5 million cubic meters of low-level wastes have been disposed in this country by shallow land burial. As Figure 1.1 shows, $50 \%$ of this was generated by commercial power reactors with the other $50 \%$ by industrial, institutional and government sources. Moreover, of all the states, Massachusetts ranked sixth in the amount of low-level waste generated in 1979 (See Table 1.1). Current estimates by the U.S. Nuclear Regulatory Commission predict that the existing capacity of the three operating commercial disposal facilities--Beatty, Nevada; Hanford, Washington; and Barnwell, South Carolina--will be exhausted between 1984 and 1989 (Figure 1.2). The governors of Nevada, Washington, and South Carolina have clearly stated their positions that their states should not be asked to continue to act as the sole repositories for the nation's low-level waste. Moreover, they have suggested that additional disposal capacity be created through the construction of regional facilities.

This state briefing book has been prepared to assist the Department of Energy in its efforts to help states institute a workable waste management system. It is one of a series produced under contract with the Department of Energy, Office of Nuclear Waste Management, Idaho Operations Office, through contract with EG\&G Idaho, Inc., that will provide background information on waste management practices, state government structure and jurisdiction, relevant state statutes and regulatory programs, local government jurisdictions, nature and volume of low-level waste generation, interested groups and individuals, and state print and broadcast news media. 


\section{UNITED STATES}

Total Low-Level Radioactive Waste Disposed of at Commercial Facilities $79,914 \mathrm{~m}^{3}$

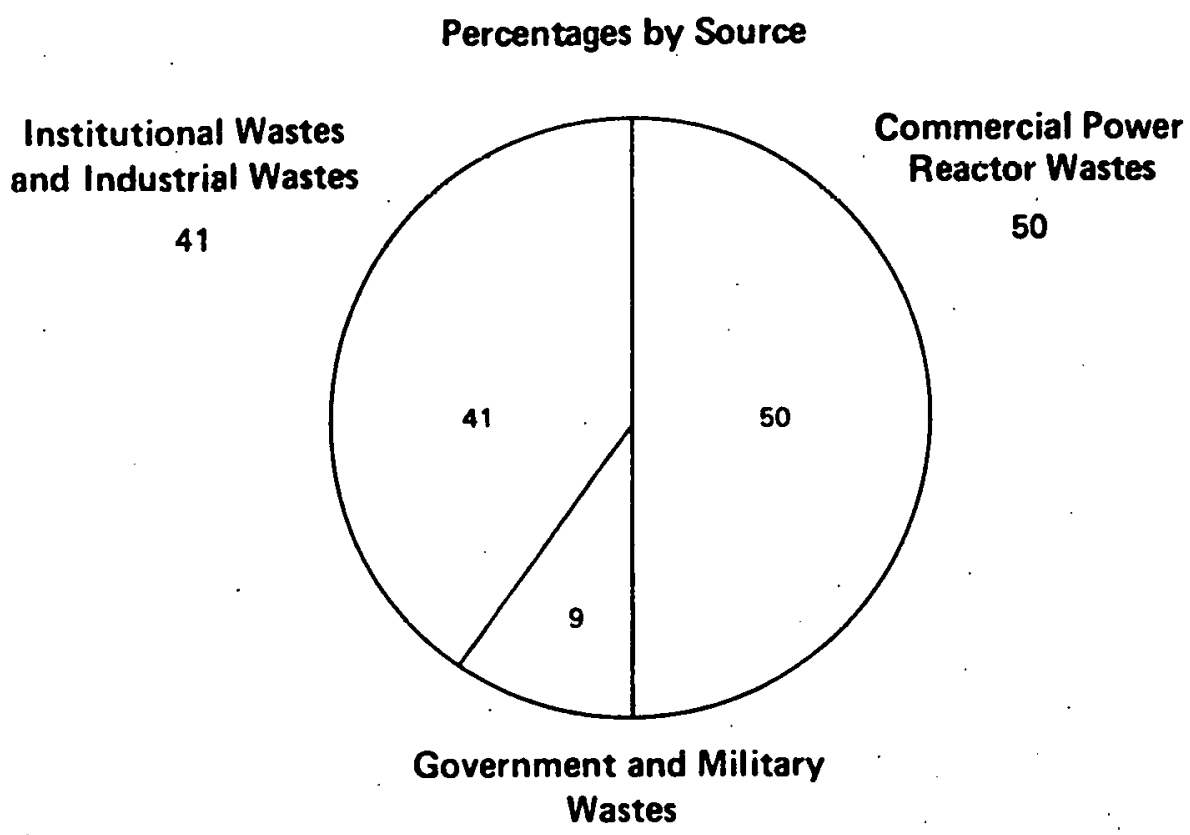

9

Commercial Power Reactor Wastes ${ }^{(a, b, c, d, e, f)}$

(Number of Installations 71 )

Volume, Radioactivity,

Waste Form

Cubic Meters

Curies

Typical Radionuclides

Spent resins, filter sludges, and evap.

15,791

40,711

orator bottoms

Dry compressible waste and contam.

21,345

6,992

inated equipment

Irradiated components

2,622

45,702

Total

39,768

93,405

${ }^{51} \mathrm{Cr}$

${ }^{54} \mathrm{Mn}$

${ }^{59} \mathrm{Fe}$

${ }^{58} \mathrm{Co}$

${ }^{60} \mathrm{Co}$

${ }^{65} \mathrm{Zn}$

${ }^{134} \mathrm{Cs}$

${ }^{136} \mathrm{Cs}$

${ }^{137} \mathrm{Cs}$

${ }^{140} \mathrm{Ba}$

${ }^{141} \mathrm{Ce}$

Fig̣ure 1.1

$1-3$ 
Waste Distribution by State, 1979

\begin{tabular}{|c|c|c|}
\hline State & $\begin{array}{c}\text { Volume, } \\
\mathrm{m}^{3}\end{array}$ & $\begin{array}{c}\text { Radioactivity, } \\
\text { curies }\end{array}$ \\
\hline Alabama & 3,672 & 9,543 \\
\hline Alaska & $<1$ & $<1$ \\
\hline Arizona & 54 & 61 \\
\hline Arkansas & 265 & 180 \\
\hline California & 4,342 & 83,281 \\
\hline Colorado & 225 & 25 \\
\hline Connecticut & 3,970 & 2,764 \\
\hline Delaware & 120 & $<1$ \\
\hline District of Columbia & 33 & 333 \\
\hline Florida & 2,592 & 88,345 \\
\hline Georgia & 1,261 & 820 \\
\hline Hawaii & 83 & 10 \\
\hline Idaho & 7 & 8 \\
\hline Illinois & 6,758 & 9,044 \\
\hline Indiana & 27 & 1 \\
\hline lowa & 961. & 1,271 \\
\hline Kansas & 10 & 3 \\
\hline Kentucky & 194 & 37 \\
\hline Louisiana & 19 & 1 \\
\hline Maine & 416 & 555 \\
\hline Maryland & 978 & 2,271 \\
\hline Massachusetts & 4,860 & 138,146 \\
\hline Michigan & 2,151 & 875 \\
\hline Minnesota & 1,461 & 13,315 \\
\hline Mississippi & 68 & 54 \\
\hline Missouri & 329 & 304 \\
\hline Montana & 3 & 32 \\
\hline Nebraska & 801 & 140 \\
\hline Nevada & 4 & 62 \\
\hline New Hampshire & 77 & 3 \\
\hline New Jersey & 3,008 & 7,450 \\
\hline New Mexico & 80 & 1 \\
\hline New York & 9,572 & 78,961 \\
\hline North Carolina & 5,304 & 4,504 \\
\hline North Dakota & 2 & $<1$ \\
\hline Ohio & 1,905 & 5,632 \\
\hline Oklahoma & 21 & 266 \\
\hline Oregon & 1,219 & 337 \\
\hline Pennsylvania & 6,825 & 2,567 \\
\hline Rhode Island & 463 & 1 \\
\hline South Carolina & 8,089 & 2,784 \\
\hline South Dakota & $<1$ & $<1$ \\
\hline Tennessee & 1,131 & 56 \\
\hline Texas & 543 & 410 \\
\hline Utah & 106 & 9 \\
\hline Vermont & 370 & 918 \\
\hline Virginia & 4,230 & 9,314 \\
\hline Washington & 779 & 278 \\
\hline West Virginia & 40 & 41 \\
\hline Wisconsin & 487 & 3,058 \\
\hline Wyoming & $<1$. & $<1$ \\
\hline Total United States & 79,914 & 477,440 \\
\hline
\end{tabular}

Table 1.1 


\title{
UNITED STATES
}

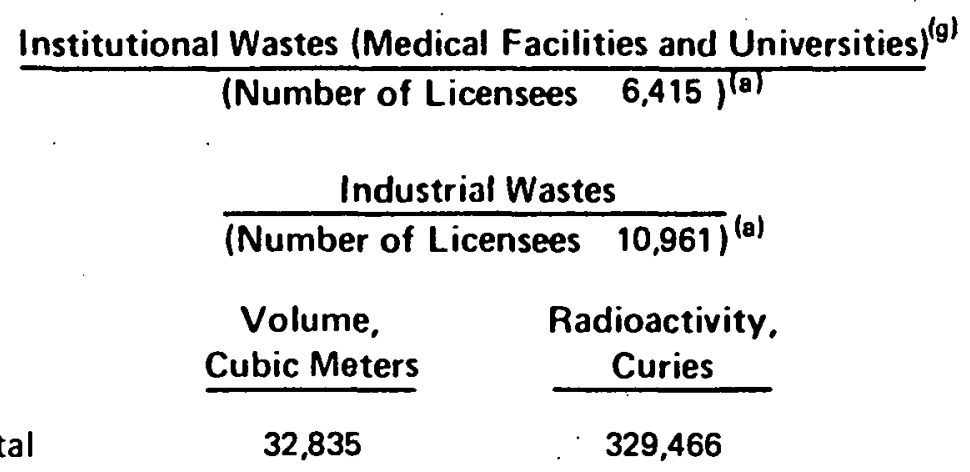

Estimated Total

32,835

329,466

Government and Military Wastes Disposed of at Commercial Sites ${ }^{(j)}$

(Number of Installations 21 )

Volume,

Cubic Meters

Radioactivity.

Total

Curies

Total

$$
7,311
$$

54,566

COMMENTS: By the best approximation available at the time of this report, the volume that could be attributed to the industrial category is 17,881 cubic meters and the volume that could be attributed to the institutional category is 14,954 cubic meters. No curie breakdown is possible from available sources of information.

\section{$\underline{\text { Total Volume and Radioactivity of Wastes Disposed of at Commercial Sites }}^{(\mathrm{h})}$}

\author{
Volume, Cubic Meters 79,914 \\ Radioactivity, Curies 477.437
}

\section{Percentages by Disposal Site}

Barnwell, 79; Richland, 13; Beatty, 8

Figure 1.2

$1-5$ 
2. OVERVIEW OF LOW-LEVEL RADIOACTIVE WASTE MANAGEMENT IN MASSACHUSETTS

Nuclear Regulatory Commission Licensees

There are approximately 410 Nuclear Regulatory Commission (NRC) licensees in Massachusetts producing an estimated 4,815 cubic meters of low-level radioactive waste annually. Massachusetts, ranking eighth in the nation in the generation of low-level waste, produces almost $50 \%$ of all radioactive waste generated in New England. As of December 31, 1980, the NRC had issued nine reactor licenses to eight licensees; there are five nuclear powered electric generating facilities in Massachusetts. There are 38 Special Nuclear Materials license holders in Massachusetts, 12 Source Materials license holders, and 360 Byproduct Materials licensees.

Current Disposal Practices

Reports to the U.S. Regulatory Commission indicate approximately $50 \%$ of the low-level waste generators in Massachusetts do not ship radioactive wastes. These generators isolate and store their wastes until the radioactive decay process renders the wastes innocuous, at which point the wastes may ve disposed of as ordinary refuse. All other low-level wastes are packaged in U.S. Department of Transportation (USDOT) approved containers, usually 55-gallon steel drums, and shipped to the commercial burial sites at either Hanford, Washington, or Barnwell, South Carolina. As of November, 1980, the unit cost of disposal for Massachusetts licensees ranged between $\$ 150$ and $\$ 250$ per 55-gallon drum. The distances separating Massachusetts and the disposal sites are great, approximately 3,000 miles and 1,000 miles respectively, and the increasing cost of motor fuel has increased the unit costs of disposal. 
Most low-level waste generators in Massachusetts do not ship wastes directly to the burial sites. Since most low-level waste is shipped to the burial sites by "exclusive use" tractor trailers, generators typically contract with a carrier who collects wastes from a number of generators and stores the waste as necessary until a full trailer-load is collected.

\section{Regulatory Enforcement}

The U.S. Atomic Energy Commission (AEC) was the first agency to develop regulations for the control of low-level radioactive wastes. The U.S. Energy Research and Development Agency, the U.S. Department of Energy, the U.S. Nuclear Regulatory Commission, the U.S. Environmental Protection Agency, and the U.S. Department of Transportation have all promulgated regulations affecting radioactive waste management. Under 1959 amendments to the Atomic Energy Act of 1954, states were granted the right to enter individual agreements with the AEC to assume licensing and regulatory authority over low-level nuclear wastes generated within their boundaries. States that did not enter into the agreement yield this authority to the Nuclear Regulatory Commission. Although Massachusetts is not an "agreement" state, the Massachusetts Department of Public Health has promulgated regulations to control hazards associated with radioactive materials and machines that emit ionizing radiation. The Department of Public Health's responsibility extends primarily to the small-volume generators of low-level waste, as in the fields of medicine and research.

The states of Nevada, South Carolina, and Washington have regulations covering packaging and shipping regulations of low-level wastes. Shipments of low-level wastes that are improperly packaged or are in violation of $\mathrm{NRC}$ rules may be rejected at the disposal site. 


\section{The Massachusetts Advisory Council on Radiation Protection}

The Massachusetts Advisory Council on Radiation Protection produced a report, Low-Level Radioactive Waste Management in Massachusetts, in November, 1980, at the request of Governor King (the full text of the report is Appendix A of this briefing book). The report concluded that Massachusetts cannot depend on Nevada, South Carolina, and Washington to accept Massachusetts' low-level wastes indefinitely. The report urged that Massachusetts initiate a low-level waste management program within the state. It suggested that it could be advantageous for Massachusetts to enter into a regional agreement with other states to share the "costs, facilities, and sites" associated with low-level radioactive waste management. 


\section{DEMOGRAPHY}

\section{Introduction}

This demographic analysis for Massachusetts is designed to ascertain and analyze various demographic factors, data and trends that could be related to the quantity, nature, and potential management options of low-level radioactive wastes within the State and its subunits.

State Economic Areas. Before addressing each part of the demographic analysis, note that interpretation will be provided for the State of Massachusetts but also for its subunits, namely, its State Economic Areas. State Economic Areas are often used in demographic investigations of the subunits of states because most states are heterogeneous in terms of urban-rural distributions, climate, industry, topography, population size and growth, and economic activity, and it is not feasible to investigate these phenomena strictly at the state level. It is necessary to reduce the the state's geography into smaller units of analysis, but not so small that their number becomes too cumbersome for analysis; this might be the case were one to disaggregate the state into counties. The State Economic Area is an appropriate unit for the subject in this study and is midway in size between the state and the county. In the next paragraph we provide more infurmation about this particular unit of analysis (See U.S. Bureau of the Census, 1972).

State Economic Areas. . Definition--State Economic Areas are relatively homogeneous subdivisions of a state, consisting of single counties or groups of counties which have similar economic and social characteristics. The boundaries of these areas have been drawn in such a way that each state is subdivided into relatively few parts, with each part having significant characteristics which distinguish it from adjoining areas. 
In the establishment of SEA's, factors in addition to industrial and commercial activities were taken into account. Demographic, climatic, physiographic, and cultural factors, as well as factors pertaining more directly to the production and exchange of agricultural and nonagricultural goods, were considered. The result is an intermediate area for study; smaller than a state, and larger than a county, with a homogeneous set of characteristics. Areas of this type are well adapted for use in a wide variety of studies in which state data are not sufficiently homogeneous or the quantity of county data presents real difficulty. Moreover, a standardized set of areas makes possible studies in widely different fields on a comparable area basis.

The State of Massachusetts is divided into eight State Economic Areas, two of which are nonmetropolitan: SEA 1: Berkshire-Monadnock; SEA 2: Cape Cod; the remaining six are metropolitan and are designated by letters instead of numbers; SEA A: Springfield-Chicopee-Holyoke Metropolitan Area; SEA B: Worcester Metro Area; SEA C: Boston-LowellLawrence-Haverhill Metropolitan Area; SEA D: Brockton Metropolitan Area; SEA E: Fall River-New Bedford Metropolitan Area; SEA F: Pittsfield Metropolitan Area. These State Economic Areas are outlined and displayed on Map 3.1.

\subsection{POPULATION AND LOCATION}

According to the 1980 U.S. Census of Population, the State of Massachusetts contained a population on April 1; 1980, of 5,737,037. In this section, we first describe the population of the State and its SEA's in terms of their age compositon in 1978, 1980, and 1990. The data for 1980 and 1990 are based on population projections, and the data for 1978 on population estimates developed by the Bureau of the Census.

Looking first at the descriptions of age for 1978, we have developed population bar graphs for the State and each SEA which graph 


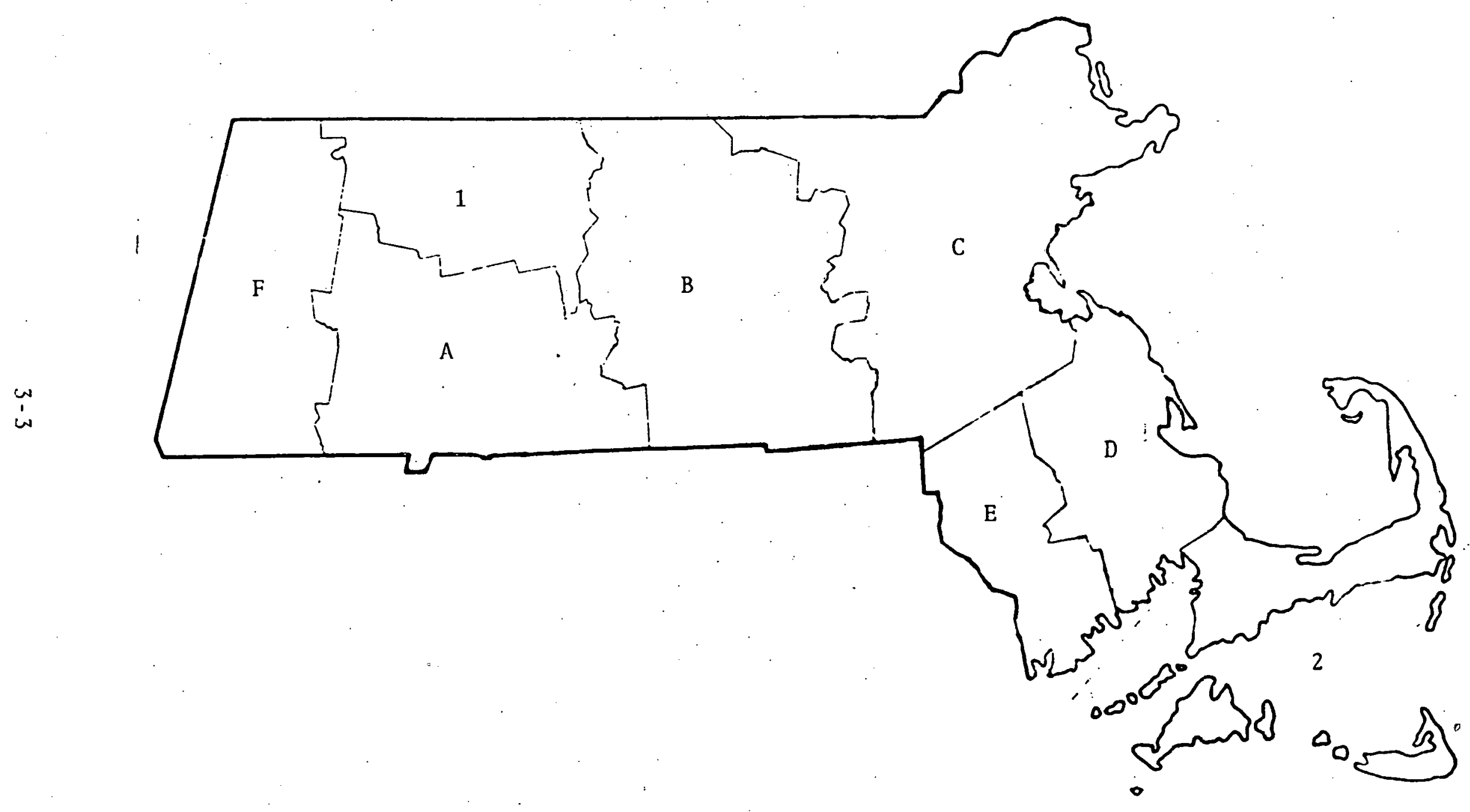

Map 3.1: Massachusetts State Economic Areas 
their age compositions. Figures 3.1.1 through 3.1.F are for the SEA's, and Figure 3.1.3 for the State as a whole.

These graphs suggest that the Cape Cod SEA (\#2) (see Figure 3.1.2) contains fewer young persons in contrast to old persons, whereas the six graphs for the metropolitan SEAs (Figures 3.1.A through 3.1.F) show an opposite interpretation.

The population projection data is presented in Table 3.1 for the SEAs and the state in 1980 and 1990. These projections are based on assumptions generally governing demographic conditions of fertility, mortality, and migration as they existed in the last half of the 1960's and the early 1970's. In some ways they therefore do not reflect exactly the demographic conditions in the State of Massachusetts during the 1970 's, especially with regard to migration. Since about the mid-1970's, many of the northeastern and north central states, including the state of Massachusetts, suffered population reductions due to net migration, and in some instances, have been losing more persons through net migration than they have gained.

At the time of this writing, the Bureau of the Census has only released the final 1980 population counts for states. Small area data, including those for counties which can then be aggregated into State Economic Areas, are not due for release until later, and the data will be total count data. We are able to compare the final 1980 count released for Massachusetts by the U.S. Bureau of the Census with that produced by our projection methodology for 1980 (see total number in Table 3.1). Clearly, our projected 1980 total for the State of Massachusetts of $6,585,566$ greatly overpredicts the census final count for April 1, 1980, of 5,737,037. Our projections on this basis are rather liberal in their attempt to identify the levels of the population in 1980 and 1990, and they should be reviewed with this in mind. 

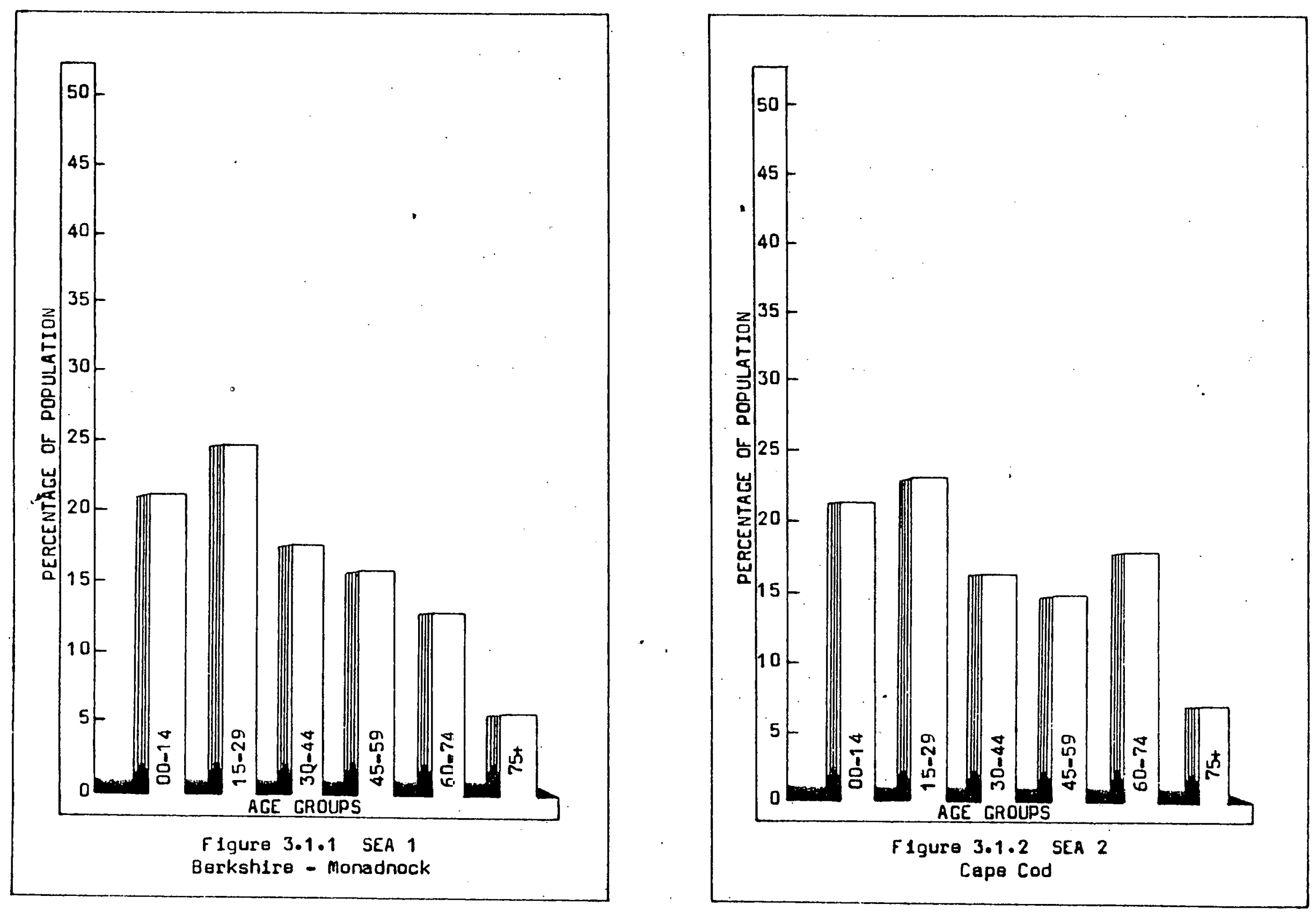

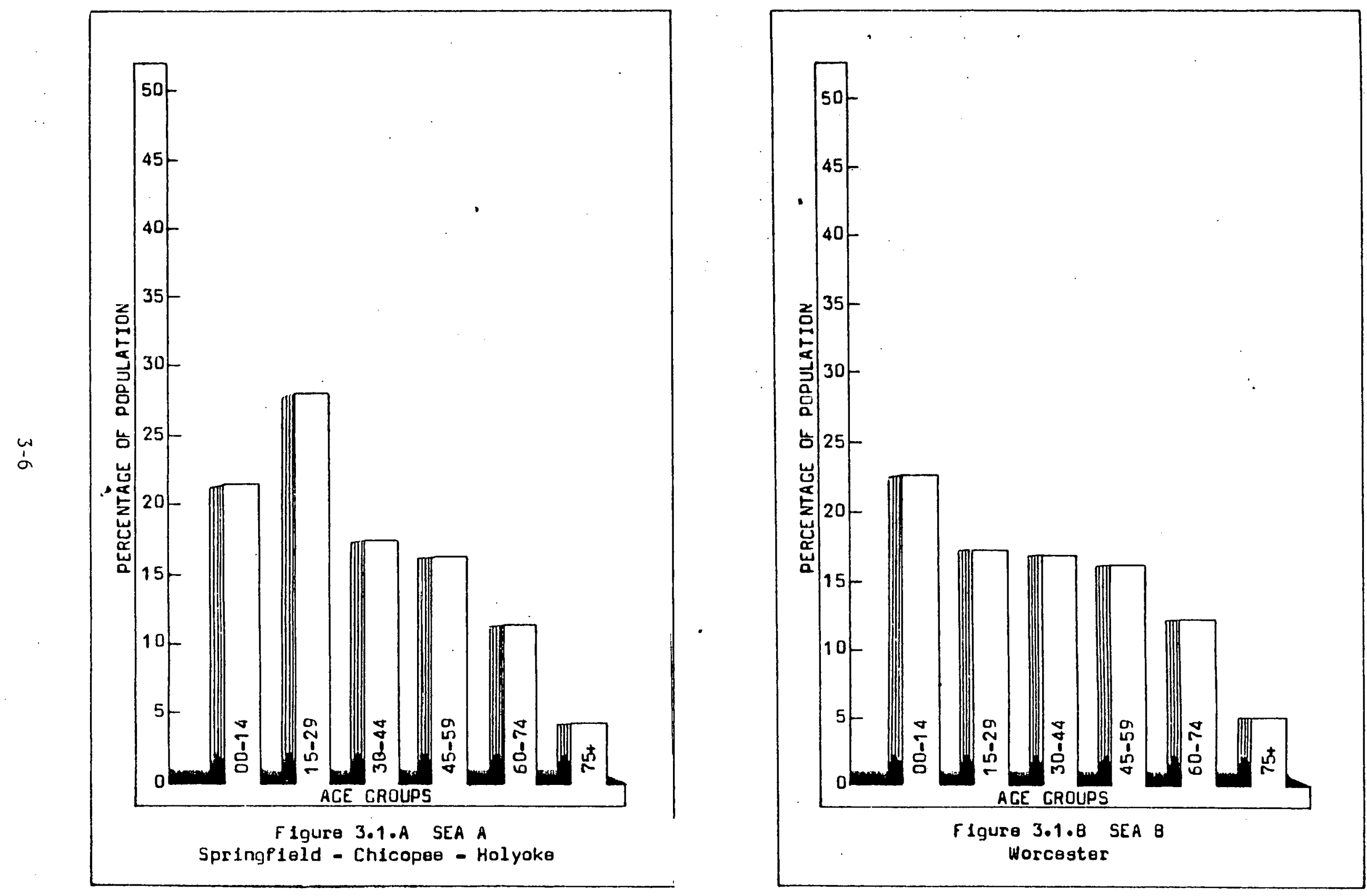

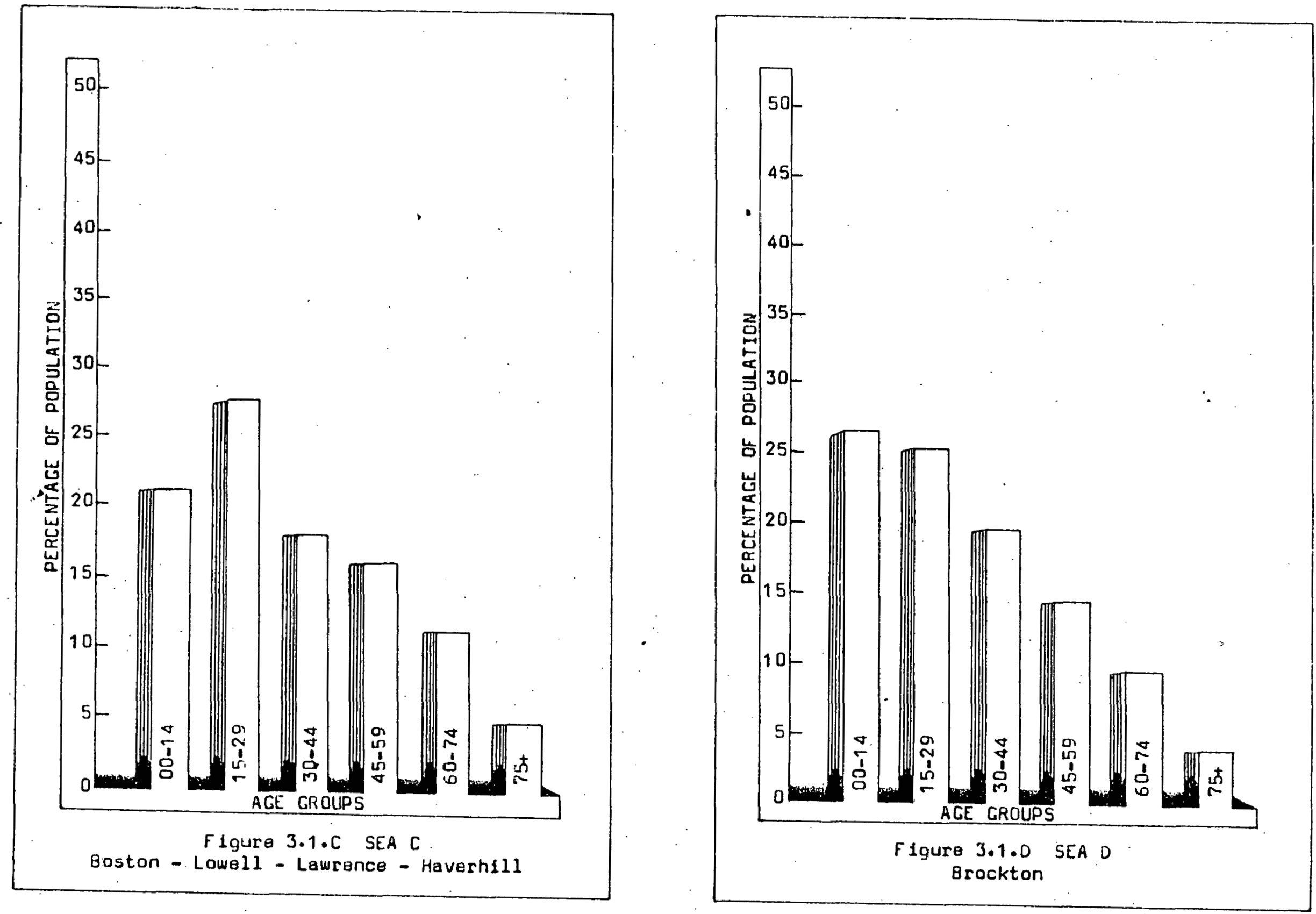

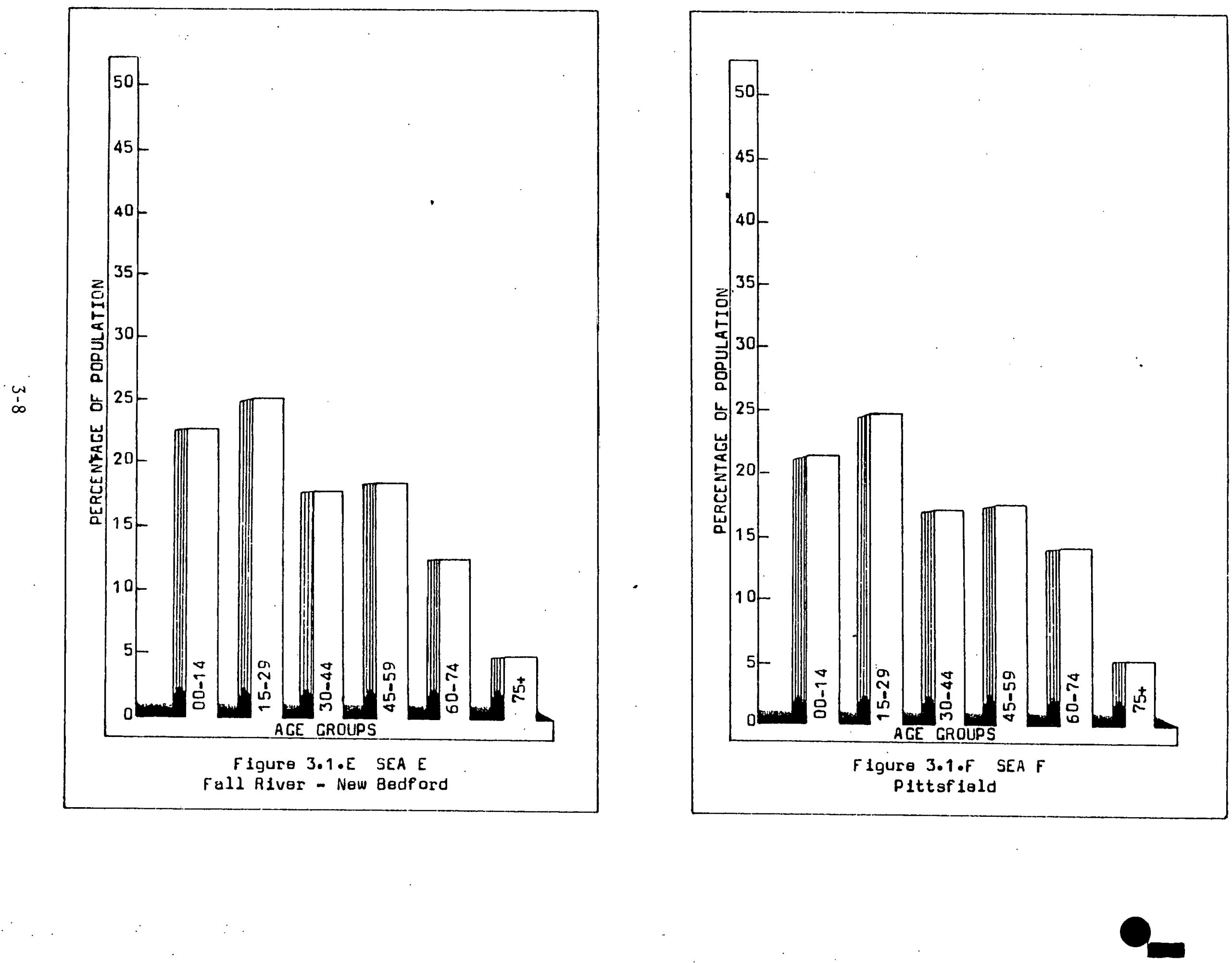


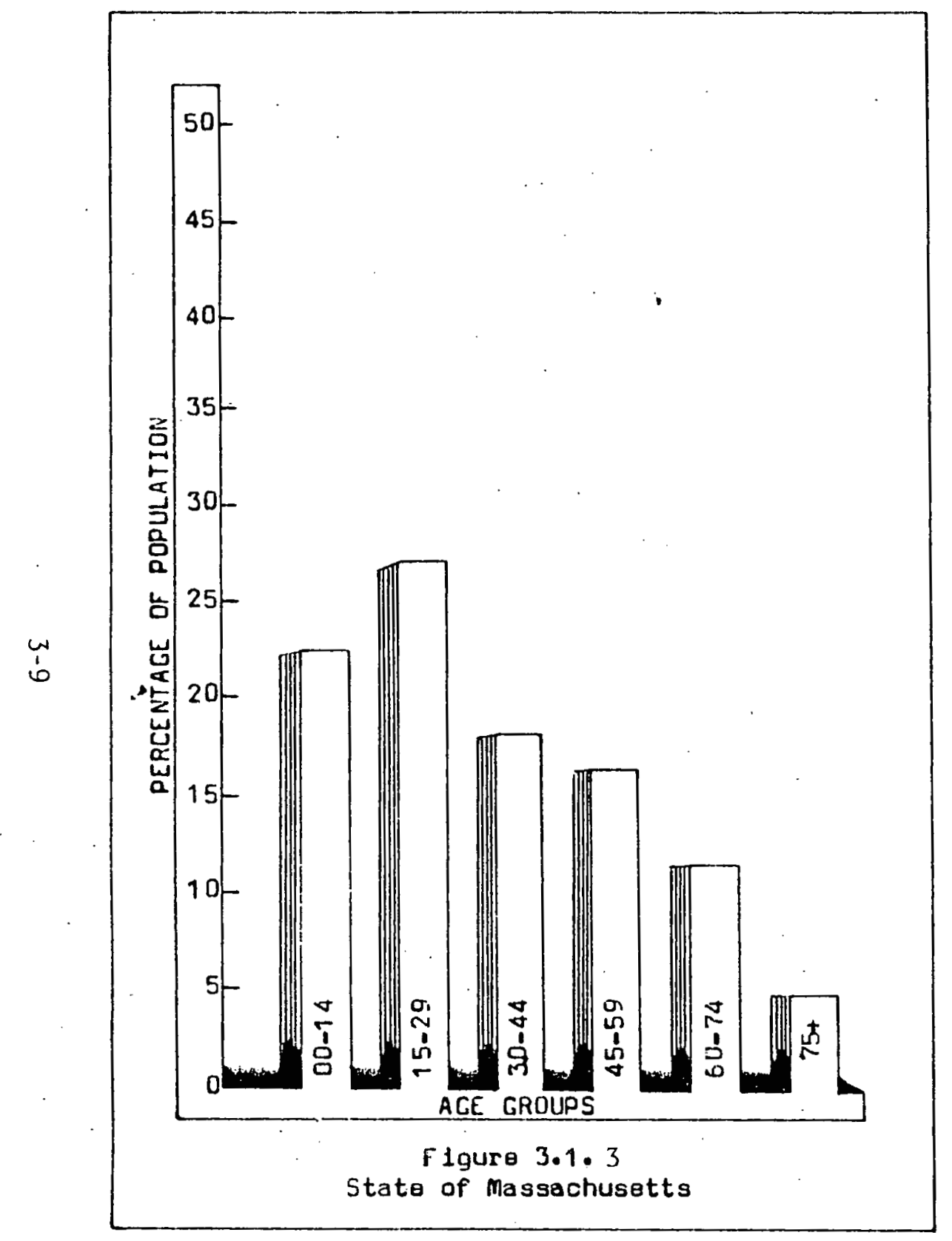


DEMOGRAPHIC GROWTH AND DENSITY INFORMATION FOR THE STATE OF MASSACHUSETTS AND ITS STATE ECONOMIC AREAS,

July 1, 1970 - July 1, 1978

AND POPULATION PROJECTIONS FOR 1980 AND 1990

\begin{tabular}{|c|c|c|c|c|c|c|}
\hline State & Economic Area & $\begin{array}{l}\text { Population } \\
\text { Growth Rate } \\
1970-78 \quad(\%)\end{array}$ & $\begin{array}{l}\text { Growth Rate } \\
\text { Due to Net } \\
\text { Migration } \\
1970-78(\%)\end{array}$ & $\begin{array}{l}\text { Population } \\
\text { Density per } \\
\text { Square Mile } \\
1978 \\
\end{array}$ & $\begin{array}{l}\text { Population } \\
\text { Projection } \\
1980\end{array}$ & $\begin{array}{l}\text { Population } \\
\text { Projection } \\
\quad 1990\end{array}$ \\
\hline SEA 2 & Cape Cod & 43.7 & 45.2 & 287. & 176,361 & 284,793 \\
\hline SEA B & Worcester Metro Area & 1.1 & -1.7 & 427 & 666,554 & 817,941 \\
\hline SEA C & $\begin{array}{l}\text { Boston-Lowell- } \\
\text { Lawrence-Haverhill } \\
\text { Metro Area }\end{array}$ & -1.9 & $-4 \cdot 3$ & 1872 & $3,617,785$ & $3,955,835$ \\
\hline SEA $F$ & Pittsfield Metro Area & -3.8 & -5.4 & 153 & 192,698 & 330,621 \\
\hline STATE & OF MASSACHUSETTS & 1.3 & -1.3 & 738 & $6,585,566$ & $8,077,745$ \\
\hline
\end{tabular}

SOURCE OF DATA: Data obtained for the counties of the state from U.S. Bureau of the Census, County and City Data Book, 1977, Washington, D.C. (magnetic tape version); and U.S. Bureau of the Census, "NCI County Population Estimates, 1970-78" (magnetic tape version). 
The SEA projections for 1980 and 1990 do suggest, however, that the main core of population in the State of Massachusetts will continue to be contained within SEA C: The Boston-Lowell-Lawrence-Haverhill State Economic Area. Despite the fact that the projected amounts are likely higher in 1980 than they are in reality, and higher for 1990 than they will be, they do indicate a continued presence of SEA C as the major population focal point in the State.

To this point we have restricted the demographic analysis of the population of the State of Massachusetts to matters largely involving total population size and age composition. We move now beyond these concerns to an examination of demographic growth and density for Massachusetts and its State Economic Areas. In Table 3.1, rates of population growth between 1970-78 are provided for the State and its State Economic Areas, along with growth rates due to net migration. Also presented in the table are data on population density (persons per square mile) and population projections for 1980 and 1990. A population with a positive rate of growth over an eight-year period, particularly one with a positive rate due to net migration, would imply increasing isotope use and therefore waste generation.

Of all the SEAs in the State, Boston is the most densely populated. Despite its negative rate of growth (both overall growth and growth due to net migration), this SEA remains as the major site of population concentration in the State of Masssachusetts.

Another way of viewing the demographic patterns and changes in Massachusetts and its State Economic Areas is through a series of maps. Two maps reflecting rates of overall population growth for the SEAs (Map 3.2), and patterns of population density for the State's SEAs (Map 3.3) according to three categories of density are presented also. 


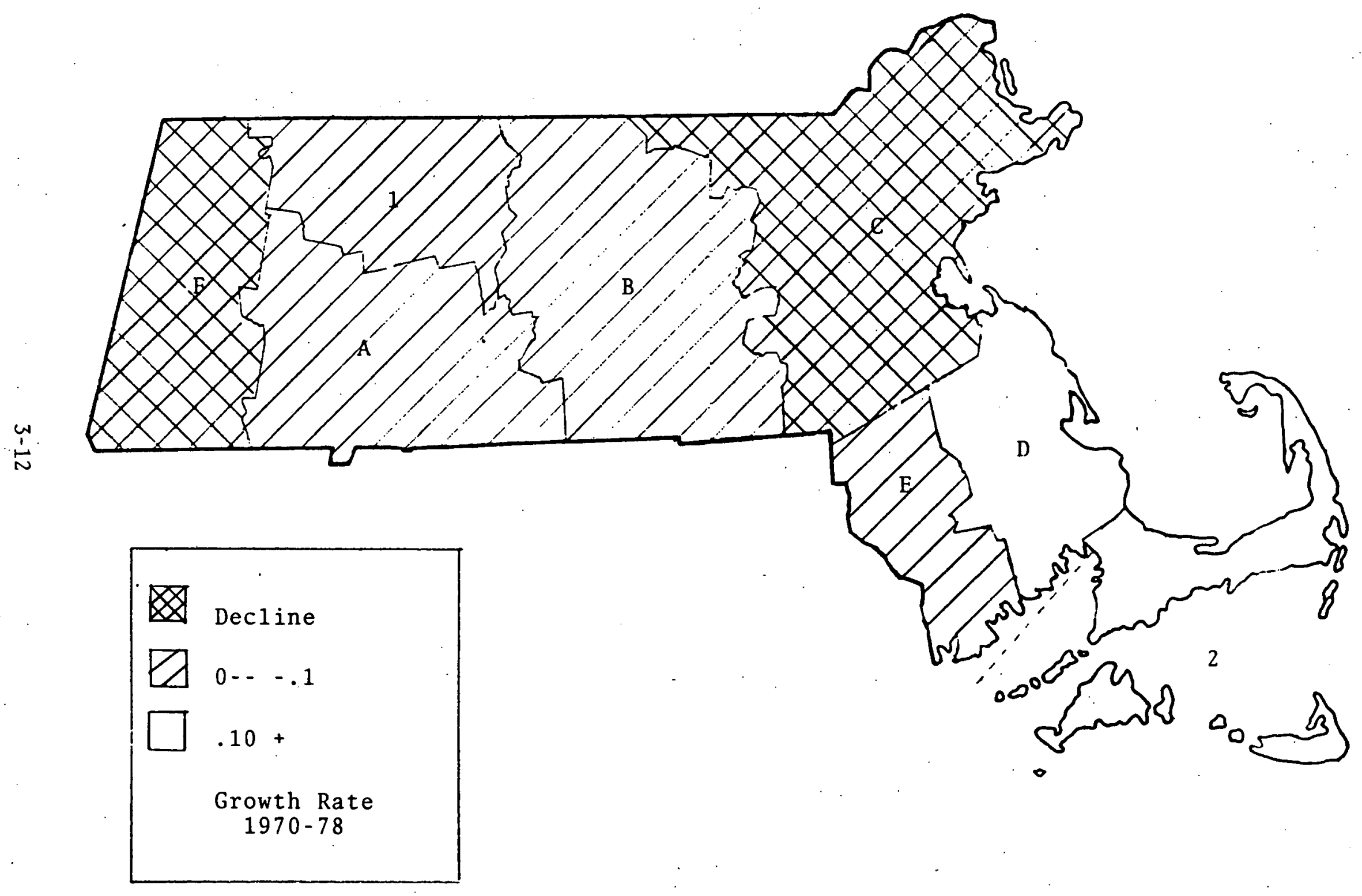

Map 3.2 Growth Rate 1970-78 


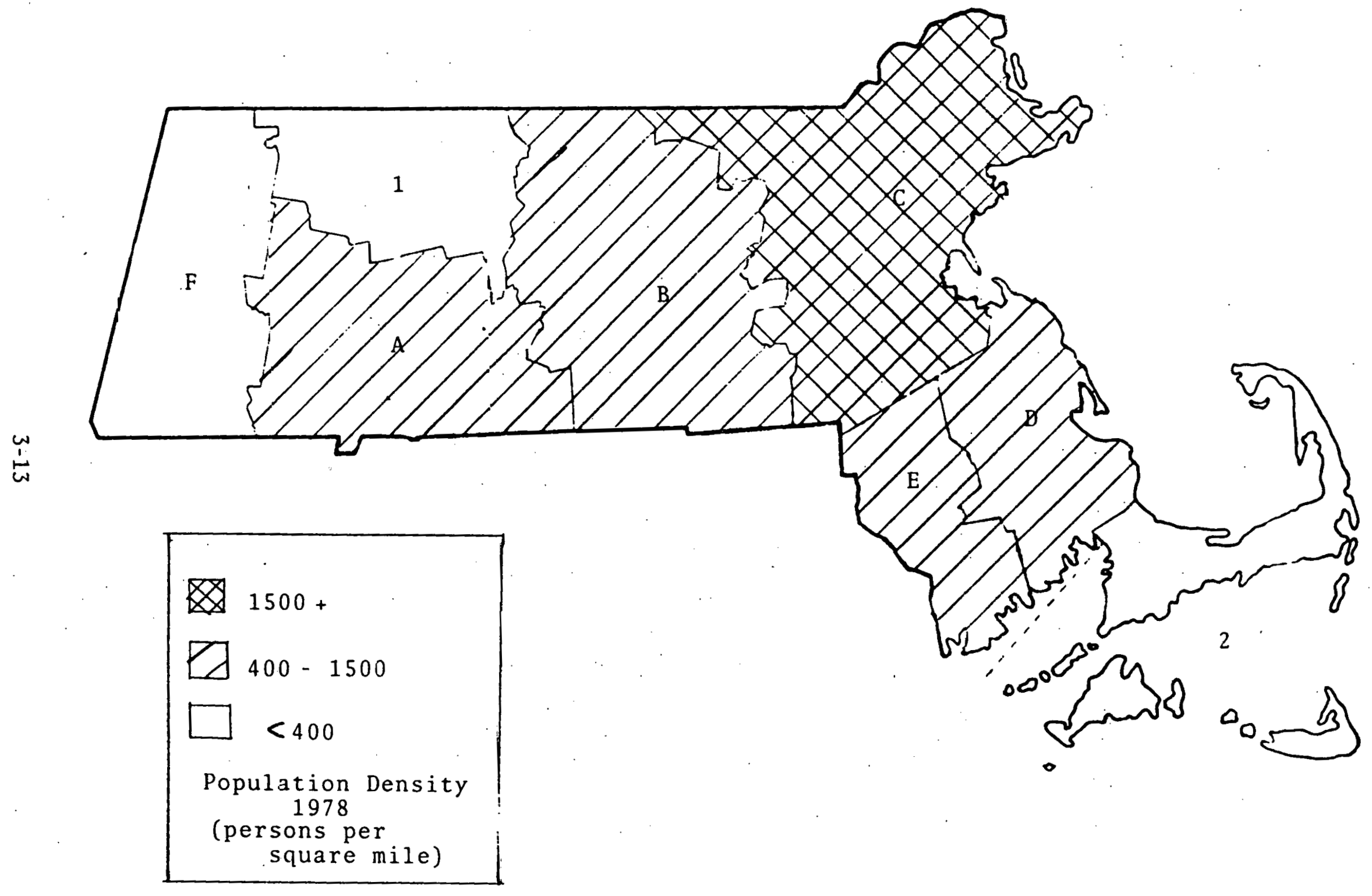

Map 3.3 Population Density, 1978 


\subsection{GOVERNMENT}

Demographic data on government employment and revenues in the State of Massachusetts and its State Economic Areas provide information on the scope of local, state, and federal government activity, and the extent to which they have changed in recent years.

Tables 3.2 and 3.3 present demographic data on government employment and revenues for Massachusetts and its State Economic Areas for 1972 and 1977. Data on government employment and payrolls are provided in Table 3.2. As expected, the SEA with the most government employees is SEA C: BostonLowell-Lawrence-Haverhill. The State of Massachusetts as a whole has the equivalent of 213,401 full-time employees in government, an increase of $13.2 \%$ over 1972 levels. Nearly $60 \%$ of the government employees in the State are located in Boston. The Boston SEA also has the most extensive government payroll in the State. And in terms of 1972 dollars, government payrolls in Boston increased by $22 \%$ between 1972 and 1977.

Table 3.3 presents general revenue data, total intergovernmental revenue data, and the amount of intergovernmental revenue from the federal government. These data are presented for both 1972 and 1977 , and they indicate that the Boston SEA has the greatest amount of general revenue in 1977 in the State: over 2.2 billion dollars. However, this amount constitutes a loss of 11.5 in terms of adjusted 1977 dollars. The State of Massachusetts had total revenue of over 4 billion dollars in 1977, an adjusted increase of $2 \%$ over 1972 revenues.

With respect to total intergovernmental revenue in 1977 , Boston again is the most prominent State Economic Area in Massachusetts. The State as a whole has nearly 1.8 billion dollars in intergovernmental revenue in 1977. Finally, in 1977, both the SEA of Boston-LowellLawrence-Haverhill and the State of Massachusetts received more than $32 \%$ of their intergovernmental revenue from the federal government. 
The government data provided in Tables 3.2 and 3.3 point again to the prominence of the Boston State Economic Area. The other SEAs in the State have relatively small shares of the government enterprise as measured by employment or revenue. Analyses of isotope utilization and waste generation must, by necessity, take this primary governmental influence into account.

\subsection{AGRICULTURE}

Demographic data on agriculture for the State of Massachusetts and its State Economic Areas indicate those areas within the State heavily engaged in agricultural activity. Data of this type could be influential in determining which areas within the State could be candidates for disposal sites for low-level radioactive waste products, and which areas should not.

Table 3.4 presents information for the State and its SEAs on the total amount of land in farms (expressed in thousands of acres) in 1974 and in 1978, and the percentage change between 1974 and 1978; the percent of all land devoted to farming in 1974 and 1978; and the simple difference between 1974 and 1978 percentages; and the average value of land and buildings per farm (in thousands of dollars) in 1974 and $19 \% 8$, and the chunge between 1974 and 1978 .

Acreage designated as "land in farms" consists primarily of agriculture land used for crops, pasture or grazing. It also includes weedland and wasteland not actually under cultivation nor used for pasture or grazing, provided it was part of the farm operator's total operation. Large acreages of woodland or watteland held for nonagricultural purposes were deleted from individual reports during the census processing operations. Except for open range and grazing land used under government permits, all grazing land was included as "land in farms" provided the place was part of a farm or ranch. 
TABLE 3.2

GOVERNMENT EMPLOYMENT AND PAYROLL DATA FOR THE STATE OF MASSACHUSETTS AND ITS STATE ECONOMIC AREAS 1972, 1977 and CHANGE BETWEEN 1972-77

\begin{tabular}{|c|c|c|c|c|c|c|c|}
\hline \multicolumn{2}{|c|}{ STATE ECONOMIC AREA } & $\underline{1972}$ & $\begin{array}{c}\text { TMENT EM } \\
1977 \\
\end{array}$ & $\begin{array}{l}\text { OYMENT } \\
\text { Change } \\
72-77(\%) \\
\end{array}$ & \multicolumn{2}{|c|}{$\begin{array}{cc}\text { GOVERNMENT PAYROLL } \\
\text { Oct. } & \text { Oct. } \\
1972 & 1977 \\
\end{array}$} & $\begin{array}{l}\text { (millions)** } \\
\text { Change } \\
72-77(\%) * * *\end{array}$ \\
\hline SEA 1: & Berkshire-Monadnock & 1705 & 2070 & 21.4 & 1.3 & 1.9 & 0 \\
\hline SEA 2: & Cape Cod & 4527 & 6071 & 34.1 & $3 \cdot 3$ & 6.2 & 33.0 \\
\hline SEA A: & $\begin{array}{l}\text { Springfield-Chicopee- } \\
\text { Holyoke Metro Area }\end{array}$ & 17481 & 20016 & 14.5 & 13.6 & 20.1 & 5.0 \\
\hline SEA B: & Worcester Metro Area & 18867 & 22890 & $21 \cdot 3$ & 14.5 & 23.6 & 15.0 \\
\hline SEA C: & $\begin{array}{l}\text { Boston-Lowell-Lawrence- } \\
\text { Haverhill Metro Area }\end{array}$ & 116871 & 127463 & 9.1 & 102.1 & 153.2 & 6.0 \\
\hline SEA D: & Brockton Metro Area & 11402 & 14465 & 26.9 & 8.9 & 15.4 & 22.0 \\
\hline SEA E: & $\begin{array}{l}\text { Fall River-New Bedford } \\
\text { Metro Area }\end{array}$ & 12992 & 15850 & 22.0 & $9 \cdot 9$ & 16.1 & 15.0 \\
\hline SEA F : & Pittsfield Metro Area & 4705 & 4376 & -7.0 & 3.7 & 4.7 & -10.8 \\
\hline STATE & F MASSACHUSETTS & 188550 & 213401 & 13.2 & 157.4 & 241.1 & 9.0 \\
\hline
\end{tabular}

*Government employment is expressed in terms of full-time equivalents.

* Local government payrolls are for the month of October of the particular year and are expressed in millions of dollars.

***The percent change in government payroll between 1972-77 was computed after converting the 1977 payroll dollars into their equivalent on the basis of 1972 dollars, hence introducing a control for inflation.

SOURCE OF DATA: Data for 1972 taken from U.S. Bureau of the Census, County and City Data Book, 1977, Washington D.C. (magnetic tape version); 1977 data taken from U.S. Bureau of the Census, Census of Governments, 1977 (machine readable data files). County data were aggregated into respective State Economic Areas. 
TABLE 3.3

GOVERNMENT FINANCE DATA FOR THE STATE OF MASSACHUSETTS AND ITS STATE ECONOMIC AREAS, 1972, 1977, and CHANGE BETWEEN · 1972-77

\begin{tabular}{|c|c|c|c|c|c|c|c|c|c|}
\hline \multirow{2}{*}{\multicolumn{2}{|c|}{ STATE ECONOMIC AREA }} & \multirow{2}{*}{$\begin{array}{l}\text { GENERAL } \\
1972\end{array}$} & \multirow{2}{*}{$\begin{array}{l}\text { REVENUE } \\
1977\end{array}$} & \multirow{2}{*}{$\begin{array}{l}\text { (millions)* } \\
\text { Change } \\
72-77(\%) * *\end{array}$} & \multicolumn{3}{|c|}{$\begin{array}{c}\text { TOTAL INTERGOVERNMENTAL } \\
\text { REVENUE (millions)*** } \\
\text { Change }\end{array}$} & \multicolumn{2}{|c|}{$\begin{array}{l}\text { INTERGOVERNMENTAI } \\
\text { REVENUE FROM FED. } \\
\text { GOVERNMENT }(\%)\end{array}$} \\
\hline & & & & & 1972 & 1977 & $72-77(\%)^{* *}$ & 1972 & 1977 \\
\hline SEA 1: & Berkshire-Monadnock & 26.2 & 43.6 & 18.0 & 8.1 & 16.3 & 90.0 & 8.3 & 29.5 \\
\hline SEA 2: & Cape Coc: & 62.4 & 131.8 & 50.0 & 9.7 & 32.1 & 135.1 & 22.4 & 23.8 \\
\hline SEA A: & $\begin{array}{l}\text { Springfield-Chicopee- } \\
\text { Holyoke Metro Arrea }\end{array}$ & 225.1 & 408.9 & 29.0 & 55.6 & 150.1 & 92.0 & 19.6 & 35.0 \\
\hline SEA B: & Worcester Metro Area & 286.1 & 454.1 & 13.0 & 72.1 & 159.4 & 57.0 & 22.2 & 23.0 \\
\hline SEA C: & $\begin{array}{l}\text { Boston-Lowell-Lawrence- } \\
\text { Haverhill Metro Area }\end{array}$ & 1814.6 & 2264.2 & $-11 \cdot 5$ & 387.6 & 1124.2 & 106.0 & 27.3 & 32.4 \\
\hline SEA D: & Brockton Metro Area & 170.2 & 317.5 & 32.0 & $37 \cdot 3$ & 107.7 & 104.8 & 7.6 & 31.9 \\
\hline SEA E & $\begin{array}{l}\text { Fall River-New Bedford } \\
\text { Metro Area }\end{array}$ & $177 \cdot 3$ & 342.1 & 37.0 & 50.9 & 143.6 & 100.0 & 18.2 & 42.7 \\
\hline SEA F & : Pittsfield Metro Area & 71.1 & 104.7 & 4.0 & 17.5 & 35.7 & 45.0 & 10.2 & 18.8 \\
\hline STATE & OF MASSACHUSETTS & 2832.9 & 4066.9 & 2.0 & 636.8 & 1769.1 & 97.0 & 23.4 & 32.1 \\
\hline
\end{tabular}

* General revenue data are exclusive of interlocal revenue and are for the fiscal year which closed at various dates for each government during the 12 months ending June 30 of the particular year.

* The percent change in revenue between 1972-77. was computed after converting the 1977 dollars into their equivalent on the basis of 1972 dollars, hence introducing a control for inflation.

***Intergovernmental revenue data are exclusive of interlocal revenue.

SOURCE OF DATA: Data for 1972 taken from U.S. Bureau of the Census, County and City Data Book, 1977 ,

Washington, D.C. (magnetic tape version); 1977 data taken from U.S. Bureal of the Census, Census of Governments, 1977 (machine readable data files). County data were aggregated into respective State. Economic Areas. 
The State Economic Area in the State with the greatest number of acres devoted to farming in 1978 was Worcester with 130,000 acres, a reduction of 1,000 acres (or $0.8 \%$ ) from its 1974 level. The Cape Cod SEA had the fewest acres devoted to farming in 1978. Finally, regarding the total amount of land in the area devoted to farming, Brockton SEA had the highest percentage in 1978 with $2 \%$ of its land devoted to agriculture. As expected, of all the SEAs in the State, Cape Cod had the smallest portion of its land devoted to this pursuit.

Of the various State Economic Areas in the State of Massachusetts, the SEA of Boston had the highest average value of land and building per farm in 1978; after adjusting for inflation, this 1978 value represents an increase of more than $5 \%$ over the average value in 1974. The Pittsfield SEA was second. The Pittsfield figure for 1978 amounts to a $13.6 \%$ reduction compared to its 1974 value. The average value of land and buildings per farm in the State of Massachusetts in 1978 was $\$ 170,000$, an adjusted decrease of $7.8 \%$ compared to its 1974 value.

\subsection{TIIR ECONOMY}

This section provides a description of the economy and distribution of activities in Massachusetts and in its State Economic Areas in 1974 and in 1978. To accomplish this goal we take each State Economic Area for each of two time periods (1974 and 1978) and present detailed economic information on employment and annual payrolls for each of. nine industrial categories. Specifically, we provide the following information for each SEA (and then for the State as a whole) in 1974 and in 1978, by each of the nine industry categories: the number of employees for the week including March 12; and the annual payroll for the year (expressed in $\$ 1,000$ s).

The above data are taken from statistics provided in the County Business Patterns, a data source developed and published through the 
TABLE 3.4

DATA ON FARM POPULATION FOR THE STATE OF MASSACHUSETTS AND ITS STATE ECONOMIC AREAS, 1974,1978 \& CHANGE 1974-78

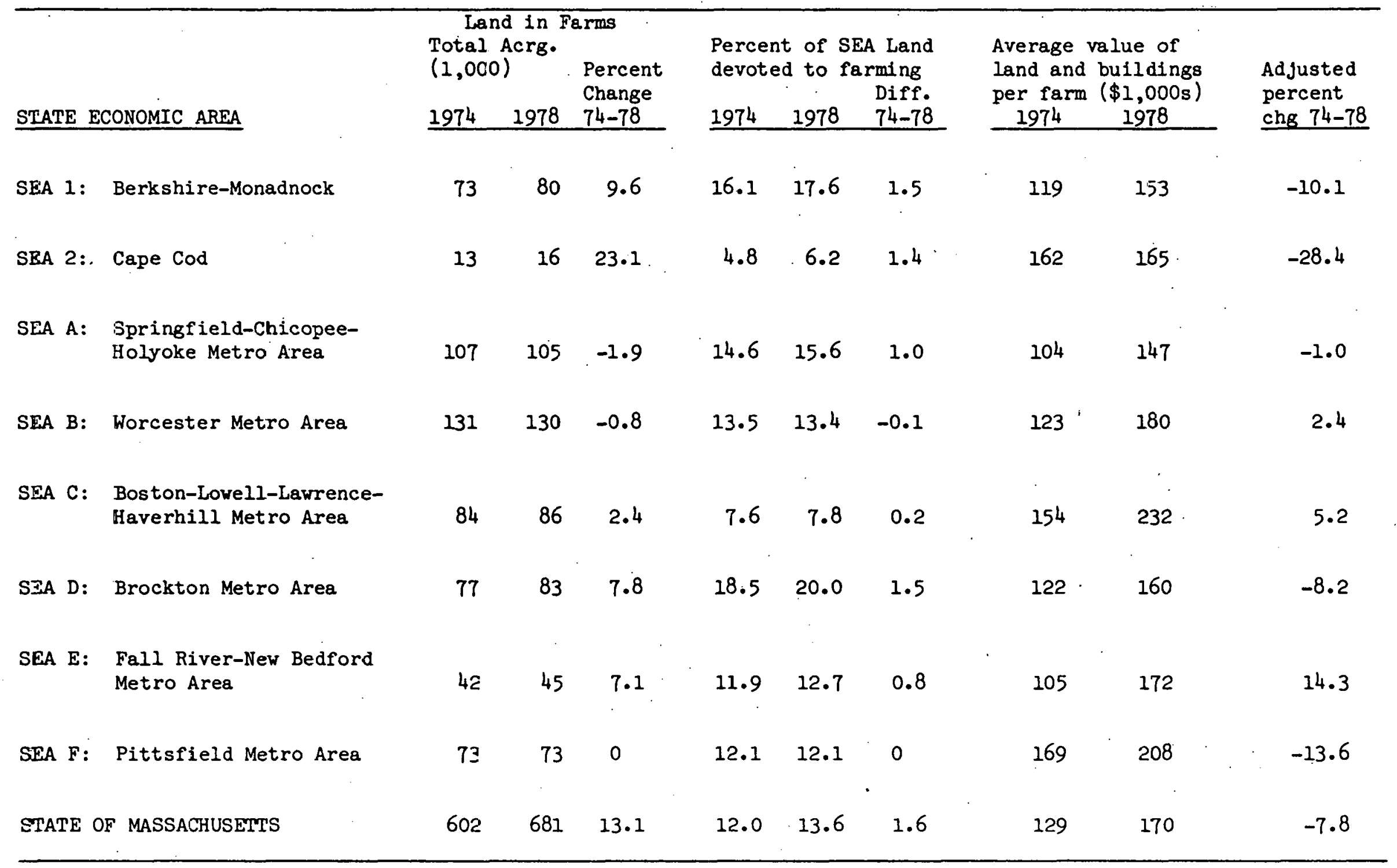

SOURCE OF DATA: Data for 1974 taken from U.S. Bureau of the Census, County and City Data Book, 1977, Washington, D.C. (magnetic tape version); 1978 data taken from U.S. Bureau of the Census, Census of Agriculture, 1978. (machine readable data files). County data were aggregated into respective State Economic Areas. 
U.S. Bureau of the Census which provides characteristics annually on the economic activity of all counties in the United States. The data reported represent general employment covered by the Federal Insurance Contributions Act.

Tables 3.5.1 through 3.5.F present the above economic data for each of the State Economic Areas for 1974 and 1978, with Table 3.5.3 providing the same information for the State of Massachusetts. Finally, Table 3.6 provides summary change data between 1974-78 for the economic payrolls of each SEA and the state in each of the nine industry categories, after adjusting for inflation.

The State of Massachusetts as a whole may be characterized mainly by manufacturing with services being of secondary importance. In 1978 manufacturing payrolls in the State amounted to over 9 billion dollars, with services totaling over 5.3 billion. The differential between the two industries with regard to the number of employees, however, is not as striking: there are nearly 651,000 manufacturing employees and almost 568,000 services employees (see Table 3.5.3). In Massachusetts, manufacturing payrolis increased by $2 \%$ and the services payrolls by $16 \%$ between $1974-7.8$ (Table 3.6 ).

Looking next at Table 3.5.1 for SEA 1 (Berkshire-Monadnock), in 1974, the manufacturing industry provides the major economic base for the SEA. There were over 6,000 manufacturing employees with an annual payroll of over 60 million dollars. In 1978, the data show the same type of industrial concentration and distributions. Finally, Table 3.6 shows that SEA 1 actually experienced a slight reduction in its manufacturing payrolls between 1974-78; after adjusting for inflation its 1978 payrolls were only 96\% of its 1974 payrolls. There were increases, however, in some of the other industrial activities in this SEA. For example, the 1978 payroll in finance, insurance and real estate reflected a 52\% increase in 1974 payrolls. An inspection of the ratios in Table 3.6 provides an informative summary of the economic conditions between 1974-78 in all SEAs and in the State. 
TABLE 3.5 .1

ECONOMIC DATA*FOR STATE ECONOMIC AREA 1: Berkshire-Monadnock, Massachusetts, 1974 and 1978 .

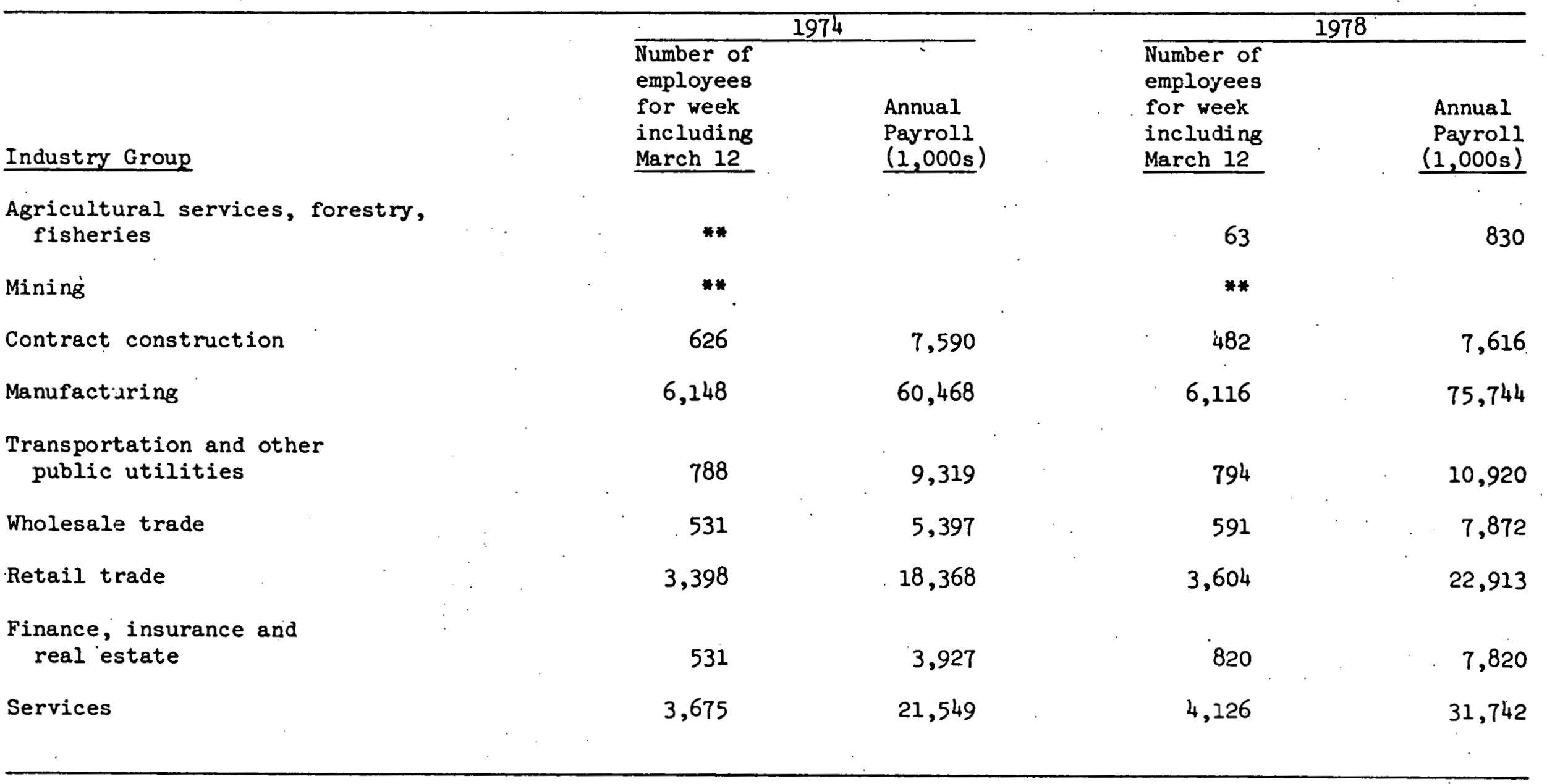

*Excludes government employees, railroad employees, self-employed persons.

**Data suppressed to preserve confidentiality.

SOURCE OF DATA: U.S. Bureau of the Census, County Business Patterns, 1974 and 1978 (machine readable data files). County data were aggregated into State Economic"Area data. 
TABLE 3.5 .2

ECONOMIC DATA*FOR STATE ECONOMIC AREA 2: Cape Cod, Massachusetts, 1974 and 1978

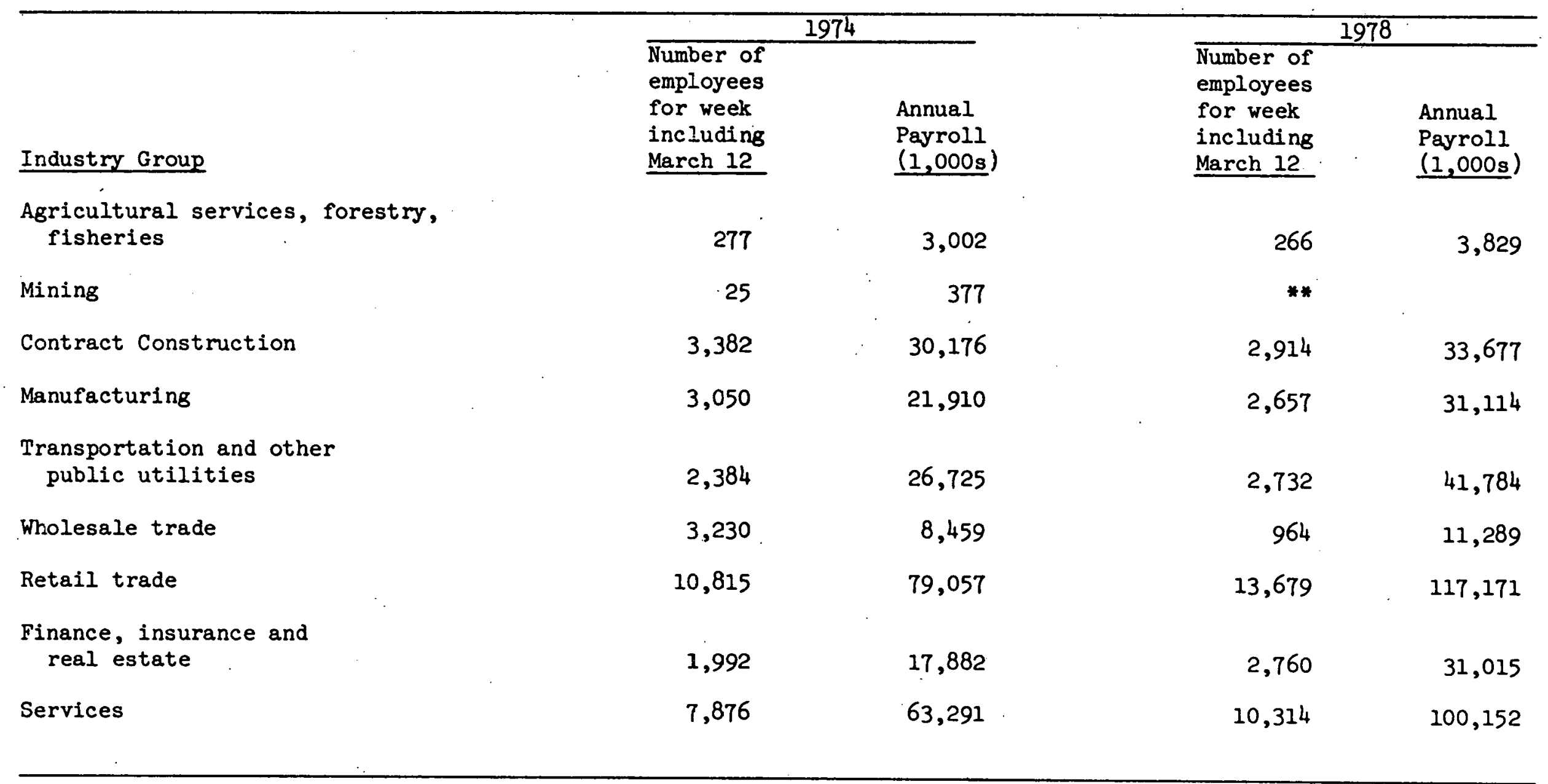

\footnotetext{
*Excludes government employees, railroad employees, self-employed persons.

SOURCE OF DATA: U.S. Bureau of the Census, County Business Patterns, 1974 and 1978 (machine readable data files). County data were aggregated into State Economic Area data.
} 
TABLE $3 \cdot 5 \cdot A$

ICONOMIC DATA*FOR STATE ECONOMIC AREA A: Springfield-Chicopee-Holyoke, Massachusetts, 1974 and 1978

\begin{tabular}{|c|c|c|c|c|}
\hline & \multicolumn{2}{|c|}{1974} & \multicolumn{2}{|c|}{1978} \\
\hline Industry Group & $\begin{array}{l}\text { Number of } \\
\text { employees } \\
\text { for week } \\
\text { including } \\
\text { March } 12 \\
\end{array}$ & $\begin{array}{l}\text { Annual } \\
\text { Payroll } \\
(1,000 s)\end{array}$ & $\begin{array}{l}\text { Number of } \\
\text { Employees } \\
\text { for week } \\
\text { including } \\
\text { March } 12 \\
\end{array}$ & $\begin{array}{l}\text { Annual } \\
\text { Payroll } \\
(1,000 s)\end{array}$ \\
\hline $\begin{array}{l}\text { Agricultural services, forestry, } \\
\text { fisheries }\end{array}$ & 189 & 1,531 & 404 & 3,782 \\
\hline Mining & ** & & 124 & 2,056 \\
\hline Contract construction & 6,588 & 85,554 & 5,036 & $80 ; 321$ \\
\hline Manufacturing & 66,465 & 652,742 & 66,794 & 869,054 \\
\hline $\begin{array}{l}\text { Transportation and other } \\
\text { public utilities }\end{array}$ & 8,528 & 91,211 & 8,695 & 122,983 \\
\hline Wholesale trade & 9,915 & 101,713 & 9,919 & 134,408 \\
\hline Retail trade & 45,070 & 211,871 & 39,879 & 259,914 \\
\hline $\begin{array}{l}\text { Finance, insurance and } \\
\text { real estate }\end{array}$ & 12,811 & 104,741 & 16,408 & 246,636 \\
\hline Services & 39,690 & 255,211 & 47,457 & 367,617 \\
\hline
\end{tabular}

*Excludes government employees, railroad employees; self-employed persons.

**Data suppressed to preserve confidentiality.

SOURCE OF DATA: U.S. Bureau of the Census, County Business Patterns, 1974 and 1978 (machine readable data files). County data were aggr $=g a t e d$ into State Economic Area data. 
ECONOMIC DATA*FOR STATE ECONOMIC AREA B: Worcester, Massachusetts, 1974 and 1978

\begin{tabular}{|c|c|c|c|c|}
\hline & \multicolumn{2}{|c|}{1974} & \multicolumn{2}{|c|}{1978} \\
\hline Industry Group & $\begin{array}{l}\text { Numjer of } \\
\text { employees } \\
\text { for week } \\
\text { including } \\
\text { March } 12 \\
\end{array}$ & $\begin{array}{l}\text { Annual } \\
\text { Payroll } \\
(1,000 s)\end{array}$ & $\begin{array}{l}\text { Number of } \\
\text { employees } \\
\text { for week } \\
\text { including } \\
\text { March } 12 \\
\end{array}$ & $\begin{array}{l}\text { Annual } \\
\text { Payroll } \\
1,000 \text { s) }\end{array}$ \\
\hline $\begin{array}{l}\text { Agricultural services, forestry, } \\
\text { fisheries }\end{array}$ & $* *$ & & 351 & 4,141 \\
\hline Mining & ** & & 44 & 761 \\
\hline Contract construction & $=0,705$ & 143,643 & 8,340 & 140,830 \\
\hline Manufacturing & 99,295 & 968,299 & 93,034 & $1,239,604$ \\
\hline $\begin{array}{l}\text { Transportation and other } \\
\text { public utilities }\end{array}$ & 8,056 & 85,930 & 8,559 & 118,647 \\
\hline Wholesale trade & 10,462 & 118,565 & 11,870 & 156,954 \\
\hline Retail trade & 38,756 & 205,037 & 41,588 & 267,300 \\
\hline $\begin{array}{l}\text { Finance, insurance and } \\
\text { real estate }\end{array}$ & 8,992 & 79,901 & 9,761 & 107,309 \\
\hline Services & $\equiv 7,137$ & 236,815 & 48,788 & 362,207 \\
\hline
\end{tabular}

*Excludes government employees, railroad employees, self-employed persons.

**Data suppressed to preserve confidentiality.

SOURCE OF DATA: U.S. Bureau of the Census, County Eusiness Patterns, 1974 and 1978 (machine readable data files). County data were aggregated Into State Economic Area data. 


\section{TABLE $3.5 . \mathrm{C}$}

ECONOMIC DATA*FOR STATE ECONOMIC AREA C: Boston-Lowell-Lawrence-Haverhill, Massachusetts, 1974 and 1978

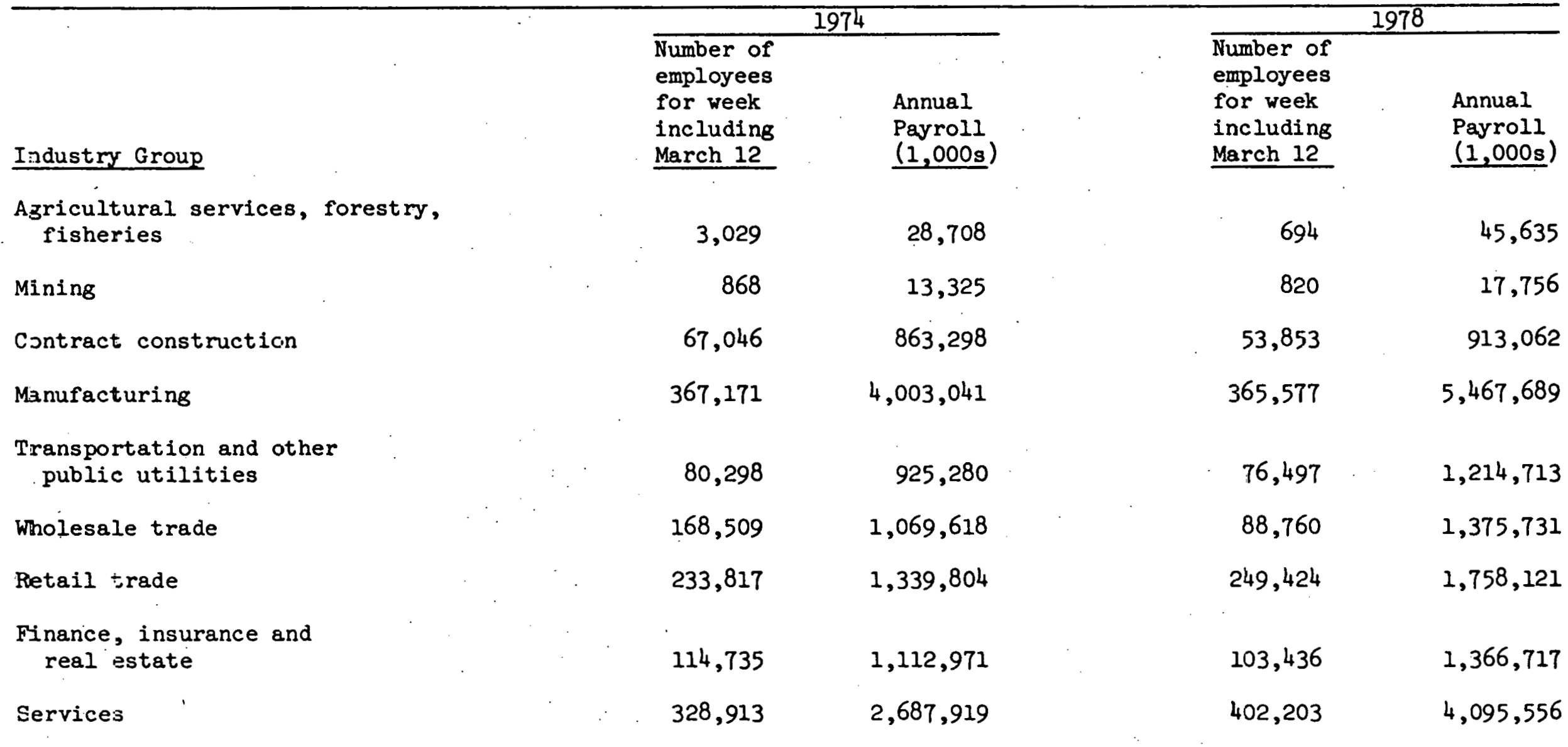

\footnotetext{
*Excludes government employees, railroad employees, self-employed persons.
}

SOURCE JF DATA: U.S. Bureau of the Census, County Business Patterns, 1974 and 1978 (machine readable data files). County data were aggregated into State Economic Area data. 
TABLE 3.5.D

ECONOMIC DATA*FOR STATE ECONOMIC AREA D: Brockton, Massachusetts, 1974 and 1978.

\begin{tabular}{|c|c|c|c|c|}
\hline \multirow[b]{2}{*}{ Industry Group } & \multicolumn{2}{|c|}{1974} & \multicolumn{2}{|c|}{1978} \\
\hline & $\begin{array}{l}\text { Number of } \\
\text { employees } \\
\text { for week } \\
\text { including } \\
\text { March } 12 \\
\end{array}$ & $\begin{array}{l}\text { Annual } \\
\text { Payroll } \\
(1,000 s)\end{array}$ & $\begin{array}{l}\text { Number of } \\
\text { employees } \\
\text { for week } \\
\text { including } \\
\text { March } 12 \\
\end{array}$ & $\begin{array}{l}\text { Annual } \\
\text { Payroll } \\
(1,000 s)\end{array}$ \\
\hline $\begin{array}{l}\text { Agricultural services, forestry, } \\
\text { fisheries }\end{array}$ & 288 & 2,609 & 331 & 3,900 \\
\hline $\begin{array}{l}\text { Mining } \\
\text { Contract construction }\end{array}$ & $\begin{array}{r}34 \\
3,305\end{array}$ & $\begin{array}{r}489 \\
34,760\end{array}$ & $\begin{array}{r}77 \\
2,822\end{array}$ & $\begin{array}{r}240 \\
42,527\end{array}$ \\
\hline Manufacturing & 20,959 & 185,745 & 20,166 & 232,920 \\
\hline $\begin{array}{l}\text { Transportation and other } \\
\text { public utilities }\end{array}$ & 5,533 & 57,126 & 5,475 & 79,016 \\
\hline Wholesale trade & 3,326 & 37,459 & 4,287 & 58,756 \\
\hline Retail trade & 24,096 & 130,156 & 25,961 & 177,889 \\
\hline $\begin{array}{l}\text { Finance, insurance and } \\
\text { real estate }\end{array}$ & 3,162 & 25,704 & 3,774 & 40,357 \\
\hline Services & 13,092 & 87,048 & 16,647 & 140,541 \\
\hline
\end{tabular}

*Excludes government employees, railroad employees, self-employed persons.

SOURCE OF DATA: U.S. Bureau of the Census, County Business Patterns, 1974 and 1978 (machine readable data files). County data were aggregated into State Economic Area data. 
TABLE $3 \cdot 5 \cdot E$

ECONOMIC DA'TA*FOR STATE ECONOMIC AREA E: Fall River-New Bedford, Massachusetts, 1974 ard 1978

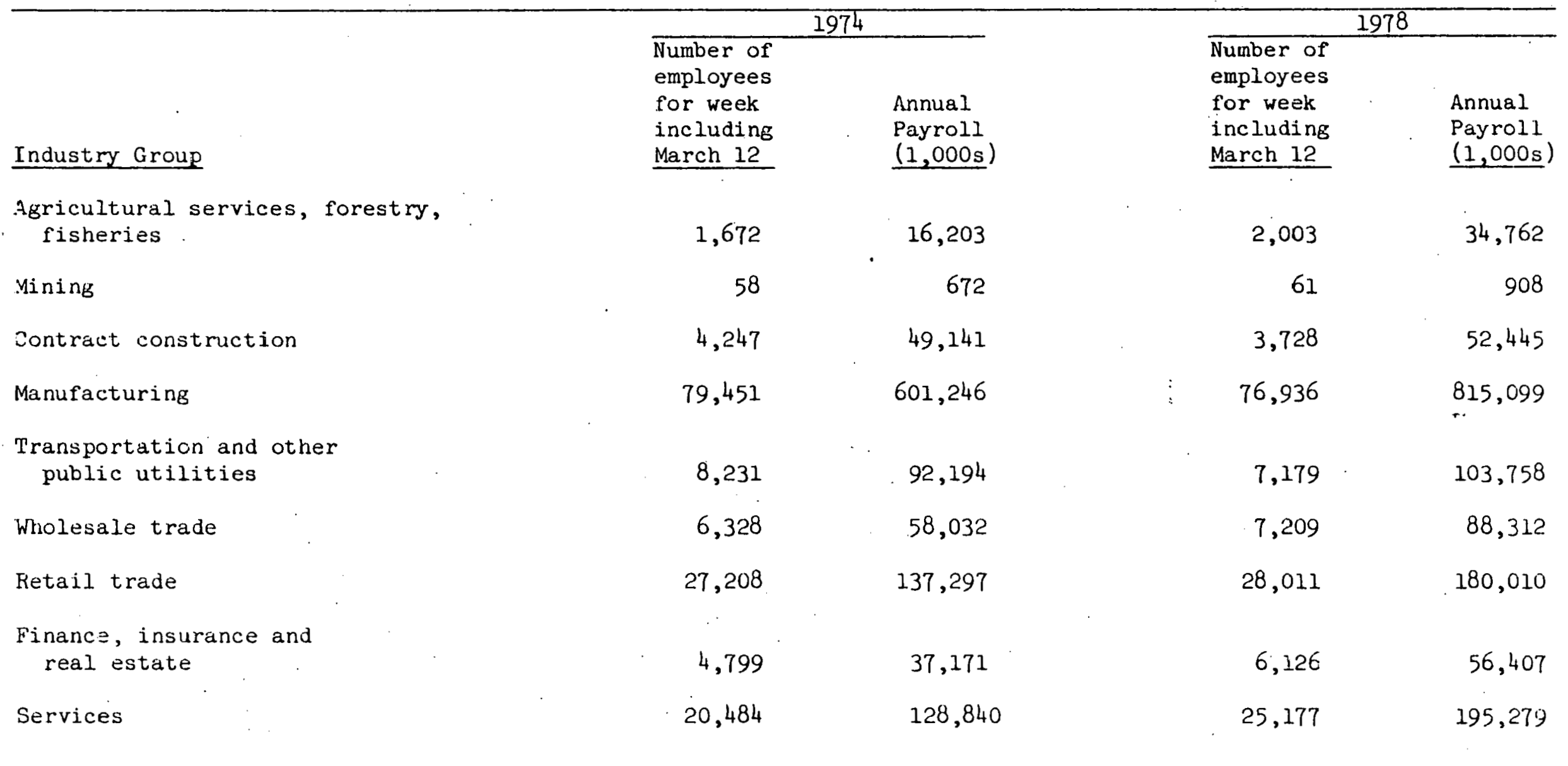

${ }^{*}$ Excludes government employees, railroad employees, self-employed persons.

SOURCE OF DATA: U.S. Bureau of the Census, County Business Patterns; 1974 and 1978 (machine readable data files). County data were a\&gregated into State Economic Area data. 
TABLE $3.5 . \dot{F}$

ECONOMIC DATA*FOR STATE ECONOMIC AREA F: Pittsfield, Massachusetts, 1974 and 1978.

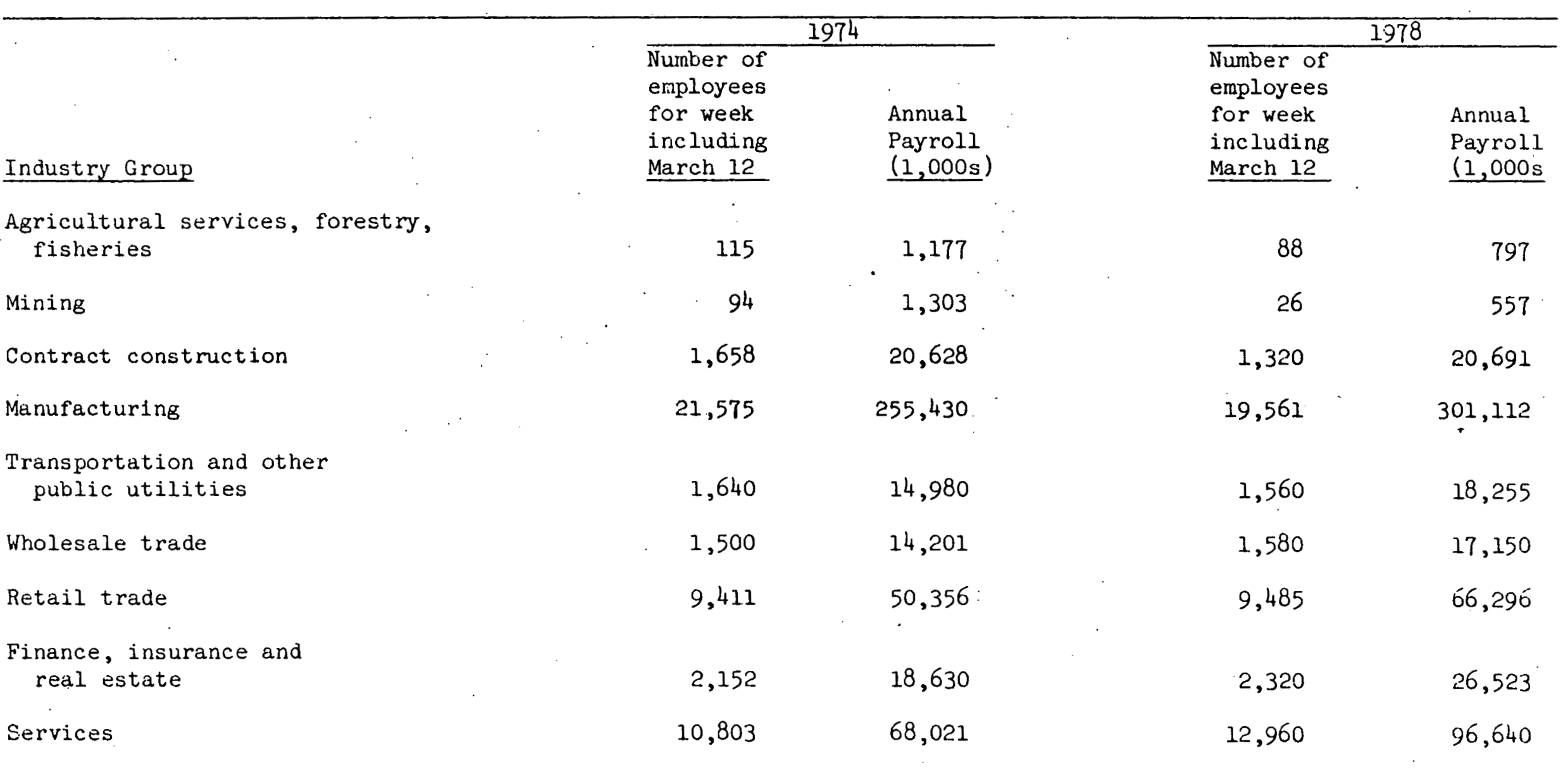

*Excludes government employees, railroad employees, self-employed persons.

SOURCE OF DATA: U.S. Bureau of the Census, County Business Patterns, 1974 and 1978 (machine readable data files). County data were aggregated into State Economic Area data. 
TABLE $3 \cdot 5 \cdot 3$

ECONOMIC DATA ${ }^{*}$ FOR STATE OF NASSACHUSETTS, 1974 and 1978

\begin{tabular}{|c|c|c|c|c|}
\hline \multirow[b]{2}{*}{ Industry Group } & \multicolumn{2}{|c|}{1974} & \multicolumn{2}{|c|}{1978} \\
\hline & $\begin{array}{l}\text { Number of } \\
\text { employees } \\
\text { for week } \\
\text { including } \\
\text { March } 12 \\
\end{array}$ & $\begin{array}{l}\text { Annual. } \\
\text { Payroll } \\
(1,000 \mathrm{~s})\end{array}$ & $\begin{array}{l}\text { Number of } \\
\text { employees } \\
\text { for week } \\
\text { including } \\
\text { March } 12 \\
\end{array}$ & $\begin{array}{l}\text { Annual } \\
\text { Payroll } \\
(1,000 s)\end{array}$ \\
\hline $\begin{array}{l}\text { Agricultural services, forestry, } \\
\text { fisheries }\end{array}$ & 6,088 & 57,402 & 7,231 & 98,154 \\
\hline M:ning & ** & - & 1,183 & 23,907 \\
\hline Contract construction & 97,557 & $1,234,791$ & 78,539 & $1,291,910$ \\
\hline Manufacturing & 664,848 & $6,757,311$ & 650,841 & $9,032,336$ \\
\hline $\begin{array}{l}\text { Transportation and other } \\
\text { public utilities }\end{array}$ & 115,804 & $1,306,893$ & 111,491 & $1,710,076$ \\
\hline Wrolesale trade & 121,119 & 1,$413 ; 449$ & 125,180 & $1,850,620$ \\
\hline Retail trade & 392,590 & $2,171,991$ & 411,631 & $2,850,042$ \\
\hline $\begin{array}{l}\text { Finance, insurance and } \\
\text { real estate }\end{array}$ & 149,237 & $1,401,380$ & 145,405 & $1,833,779$ \\
\hline Services & 461,687 & $3,548,822$ & 567,672 & $5,389,888$ \\
\hline
\end{tabular}

*Excludes government employees, railroad employees, self-employed persons.

**Data not given for State because of suppression for confidentiality in some state Economic Areas.

SOURCE OF DATA: U.S. Bureau of the Census, County Business Patterns, 1974 and 1978 (machine readable data files). County data were aggregated into State Economic. Area data. 
CHANGE IN ECONOMIC PAYROLLS* BE'WEEN 1974 AND 1978 (IN CONSTANT DOLLARS).FOR THE STATE OF MASSACHUSETTS AND ITS STATE ECONOMIC AREAS, BY EACH OF NINE INDUSTRIAL CATBGORIES

\begin{tabular}{|c|c|c|c|c|c|c|c|c|c|}
\hline \multirow[b]{2}{*}{ INDUSTRY } & \multirow[b]{2}{*}{ STATE } & \multicolumn{8}{|c|}{ STATE ECONOMIC AREAS } \\
\hline & & SEA I & SEA 2 & SEA A & SEA B & SEA C & SEA D & SEA E & SEA $F$ \\
\hline $\begin{array}{l}\text { Agricultural services, forestry, } \\
\text { fisheries }\end{array}$ & 1.31 & ** & .97 & 1.88 & ** & 1.21 & 1.14 & 1.64 & .52 \\
\hline Mining & ** & ** & ** & ** & ** & 1.02 & .37 & 1.03 & .33 \\
\hline Contract construction & .80 & .77 & .85 & .72 & .75 & .81 & .93 & .81 & .77 \\
\hline Manufacturing & 1.02 & .96 & 1.08 & 1.02 & .98 & 1.04 & .96 & 1.03 & .90 \\
\hline $\begin{array}{l}\text { Transportation and other } \\
\text { fublic utilities }\end{array}$ & 1.00 & .89 & 1.19 & 1.03 & 1.05 & 1.00 & 1.06 & .86 & .93 \\
\hline Wholesale trade & 1.00 & 1.11 & 1.02 & 1.01 & 1.01 & .98 & 1.20 & 1.16 & $\cdot 92$ \\
\hline Retail trade & 1.00 & .95 & 1.13 & .94 & 1.00 & 1.00 & 1.04 & 1.00 & 1.00 \\
\hline $\begin{array}{l}\text { Finance, insurance and } \\
\text { real estate }\end{array}$ & 1.03 & 1.52 & 1.32 & 1.80 & 1.03 & .94 & 1.20 & 1.16 & 1.09 \\
\hline Services & 1.16 & 1.12 & 1.21 & 1.10 & 1.17 & 1.16 & 1.23 & 1.16 & 1.08 \\
\hline
\end{tabular}

${ }^{*}$ Excludes government employees, railroad employees, self-employed persons. Size class $1-4$ includes establishments having payroll but no employees during mid-March pay period.

SOURCE OF DATA: U.S. Bureau of the Census, County Business Patterns, 1978, (machine readable data files). County data were aggregated into State Economic Area data. 
Summarizing the other SEAs, we observe that the major economic activity in SEA 2 (Cape Cod) is retail trade, although services is a close second (see Table 3.6.2); both economic activities experienced an increase in payrolls between 1974-78 (Table 3.6). SEA A (Springfield) is mainly characterized by manufacturing (Table 3.5.A) and the payroll situation in the SEA increased by only 2\% between 1974-78 (Table 3.6). State Economic Area B (Worcester) is also characterized by a heavy manufacturing base (Table 3.5.B), with a slight reduction in manufacturing payroll between 1974-78 (Table 3.6). The Boston State Economic Area (SEA C) is mainly manufacturing and services (Table 3.5.C); its 1978 payroll in manufacturing amounted to almost 5.5 billion dollars, whereas its services payroll in the same year was just under 4.1 billion dollars. The Boston manufacturing payroll constituted over $60 \%$ of the manufacturing payroll in the State as a whole, whereas the Boston services payroll was almost $76 \%$ of that of the State. There was a slight gain in manufacturing payrolis in Boston between 1974-78, and a marked gain (16\%) in services during the same interval (Table 3.6). As expected, Boston remains the focal point of the economic structure in Massachusetts.

The Brockton State Economic Area (SEA D) is mainly a manufacturing center, with retail trade activities following closely (Table 3.5.D); its payrolls in these two industries declined slightly in mafacturing and increased slightly in retail between 1974-78 (Table 3.6): State Economic Area E (Fall River) is minly manufacturing (Table 3.5.E), with a modest gain in manufacturing payroll (about 3\%) between 1974-78 (Table 3.6). Finally, the Pittsfield SEA (SEA F) is like most of the other SEAs of the State; it emphasizes manufacturing (Tables 3.5.F); its manufacturing payrolls, however, declined by about $10 \%$ between 1974-78 (Table 3.6). 


\subsection{HEALTH}

This section presents and analyzes selected health information for the State of Massachusetts and its State Economic Areas. Table 3.7 provides the following 1975 data: number of hospitals, number of hospital beds; hospital beds per 10,000 population; and physicians per 100,000 population. The data on hospitals and beds have been collected by the American Hospital Association for all hospitals accepted for registration by the Association. The data on physicians are collected by the American Medical Association and refer to professionally active non-Federal physicians. The data presented in this section suggest that in terms of absolute numbers of hospitals and hospital beds, the Boston SEA is at the front. The distributions of hospital beds and physicians calculated on a per population basis, however, are even more than the absolute counts. The Boston SEA is the major site for radionuclide use in a hospital/medical context.

\subsection{HIGHER EDUCATION}

Colleges and universities are major users of radionuclides. Table 3.8 provides baseline information on higher education in the State of Massachusetts and its State Economic Areas for the academic years 1974-75 and 1978-79. In the year ending in 1975, there were 122 colleges and universities in the State of Massachusetts with a student enrollment over 377,000. Four years later, the number of institutions had declined to 119 , but the student enrollment increased to slightly more than 378,000 .

The geographical distribution of institutions of higher education and their respective enrollments in the state are uneven, with more than $60 \%$ of the institutions in 1979 located in the Boston-LowellLawrence-Haverhill State Economic Area (SEA C). Some of the major 
HEAITH INFORMATION FOR THE STATE OF MASSACHUSETTS AND ITS STATE ECONOMIC AREAS, 1975

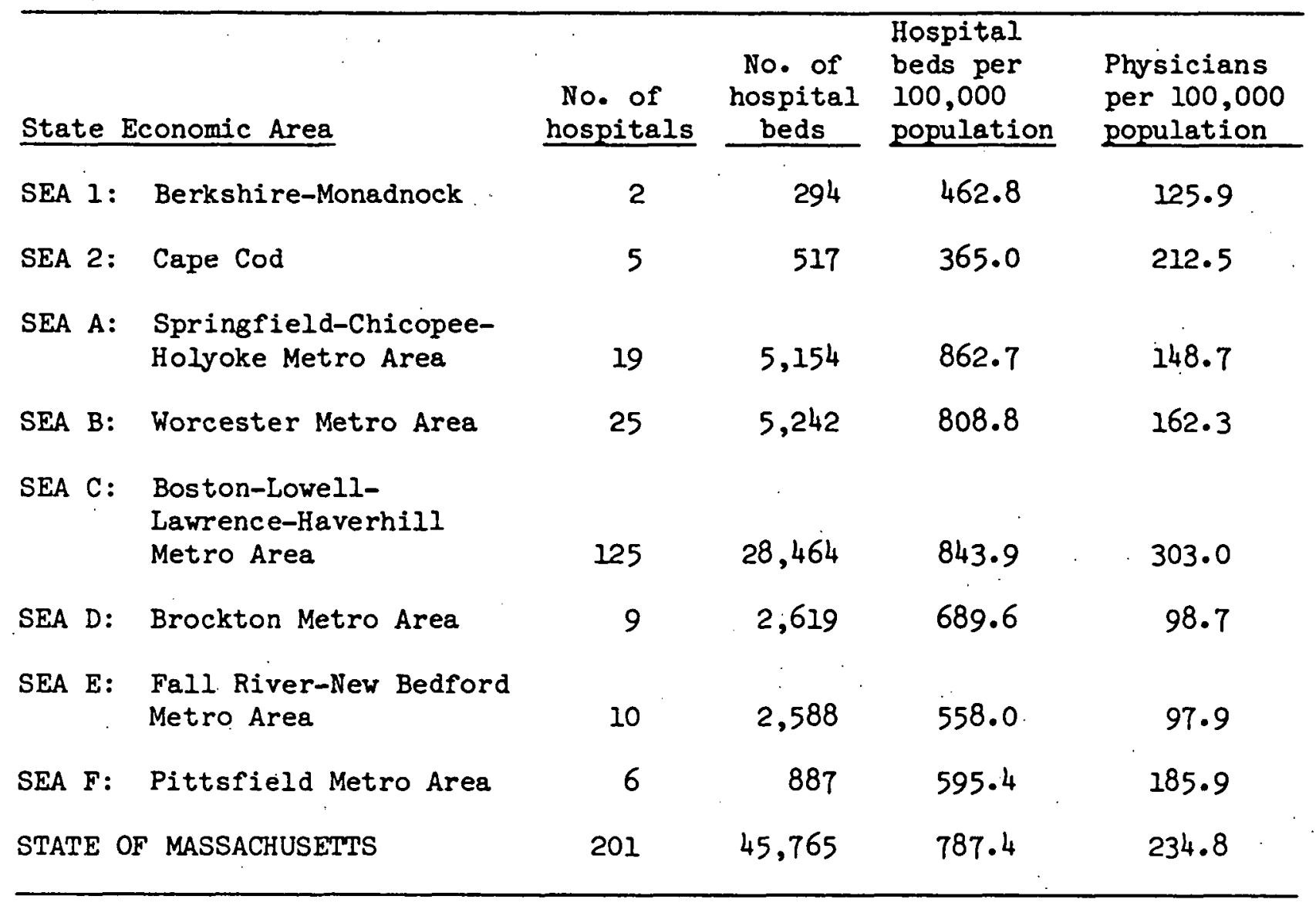

SOURCE OF DATA: Data obtained for the counties of the state from U.S. Bureau of the Census, County and City Data Book, 1977, Washington, D.C. (magnetic tape version). County data were aggregated into the respective State Economic Areas. 
universities located in this SEA are Harvard, Boston College, Boston University, and MIT. This SEA also contained more than $65 \%$ of the higher education enrollment of the state in 1979. The only other two SEAs in the State with comparable institutional or enrollment densities in 1979 are the Worcester State Economic Area (SEA B) with over 14\% of the institutions of higher education, and the Springfield-ChicopeeHolyoke State Economic Area (SEA A) with over $15 \%$ of the student enrollments. Consideration of isotope utilization and disposal, however, should focus primarily on the Boston SEA, and secondarily on the Springfield and Worcester SEAs. Clearly the Boston SEA contains the bulk of the institutions and student enrollment in the state of Massachusetts. 


\section{GOVERNMENTAL AND PUBLIC ASPECTS}

This section describes the structure and furisdiction of the Massachusetts state government. Key state government officials, the Massachusetts' delegation to Congress, and state statutes and regulations relevant to radioactive waste management are identified and briefly summarized. A discussion of print media and public action organizations is also included.

\subsection{MAJOR POLITICAL PARTIES}

The majority party in Massachusetts politics is the Democratic party. Both U.S. Senators from Massachusetts are Democrats, and of the 12 Massachusetts Congressional Representatives, ten are Democrats. The membership of the Massachusetts General Court (the state legislature) is also predominantly Democratic.

\subsection{THE MASSACHUSETTS DELEGATION}

The Massachusetts U.S. Senators and Representatives are:

\section{Senators:}

Edward M. Kennedy (D)

2241 Dirksen Senate Office Building

Washington, D.C. 20510

202-224-4543

Paul E. Tsongas (D)

342 Russell Senate Office Building

Washington, D.C. 20510

202-224-2742
Mr. Kennedy began service in 1962; he is a member of the Jolnt Economic, the Judiciary, and the Labor and Human Resources Committies.

Mr. Tsongas began service in 1979; he is a member of the Energy and Natural Resources and the Foreign Relations Committees. 
Representatives:

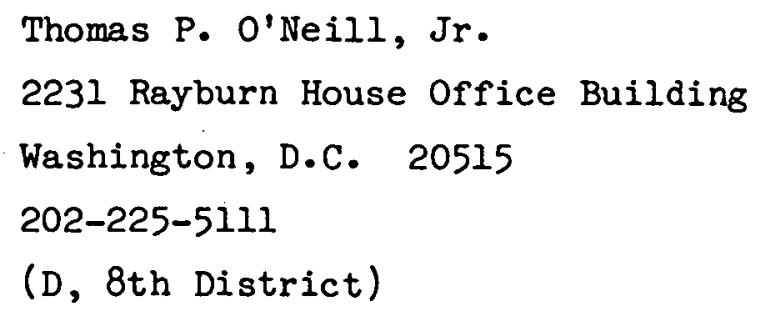

Silvio 0. Conte

2300 Rayburn House Office Building Washington, D.C. 20515

20.2-225-5335

( $R$, lst District)

Brian Donnelly

1021 Longworth House Office Building Washington, D.C. 20515

202-225-3215

(D, 1lth District)

Joseph D. Early

1032 Longworth House Office Building

Washington, D.C. 20515

202-225-6101

(D, 3rd District)
Mr. O'Neill began service in 1953 and was elected as the Speaker of the House in 1977. The speaker of the House does not serve on any legislative committees.

Mr. Boland began service in 1953; he is Chairman of thè Select Committee on Intelligence and Chairman of the HUD-Independent Agencies Subcommittee under the Appropriations Committee.

Mr. Conte began service in 1959; he is the Ranking Minority Member of the Appropriations Committee and a member of the Small Business Committee.

Mr. Donnelly began service in 1979; he is a member of the Merchant Marine and Fisheries, and the Public Works and Transportation Committees.

Mr. Early began service in 1975; he is a member of the Appropriations Committee. 
Barney Frank

2452 Rayburn House Office Building

Washington, D.C. 20515

202-225-5931

(D, 4th District)

Margaret Heckler

2312 Rayburn House Office Building

Washington, D.C. 20515

202-225-4335

( $R$, loth District)

Edward J. Markey

213 Cannon House Office Building

Washington, D.C. 20515

202-225-2836

(D, 7th District)

Nicholas Mavroules

1204 Longworth House Office Building

Washington, D.C. 20515

202-225-8020

(D, 6th District)

Joe Moakley

221 Cannon House Office Building

Washington, D.C. 20515

202-225-8273

(D, 9th District)
Mr. Frank was elected on

November 4, 1980; he is a member of the Judiciary, and the Banking, Finance and Urban Affairs Committees. Mr. Frank is also on the Select Committee on Aging.

Ms. Heckler began service in 1967; she is a member of the Agriculture, the Joint Economic, and the Veteran's Affairs Committees.

Mr. Markey began service in 1976; he is a member of the Interior and Insular Affairs, and the Interstate and Foreign Commerce Committees.

Mr. Mavroules began service in 1979; he is a member of the Armed Services, and the Science and Technology Committee.

Mr. Moakley began service in 1973; he is a member of the Rules Committee. 
James M. Shannon

226 Cannon House Office Building

Washington, D.C. 20515

202-225-3411

(D, 5th District)

Gerry E. Studds

1501 Longworth House Office Building

Washington, D.C. 20515

202-225-3111

(D, 12th District)
Mr. Shannon began service in 1979; he is a member of the Ways and Means Committee.

Mr. Studds began service

in 1973; he is a member of the Forelgn Affairs, and the Merchant Marine and Fisheries Committee. Mr. Studds is Chairman of the Coast Guard and Navigation Subcommittee.

\subsection{STATE GOVERNMENT}

The Massachusetts state government is comprised of Executive and Legislative branches and the Judiciary. This section describes the structure and jurisdiction of the Massachusetts state government and identifies major state officials.

\section{3a. EXECUTIVE BRANCH}

The executive branch of the State of Massachusetts consists of 14 constitutional officers and over 500 departments, boards, and commissions. The Constitutional Officers are the Governor, Lieutenant Governor, Attorney General, Treasurer and Receiver-General, Auditor of the Commonwealth, Secretary of the Commonwealth, and the eight members of the Governor's Council.

Massachusetts is not an NRC agreement state. Most state authority governing the installation, usage, handling, transportation and storage of sources of radiation has been concentrated within the Radiation Control Section of the Department of Public Health. 


\section{Office of the Governor}

The Governor is the "supreme executive magistrate" of the Commonwealth of Massachusetts. He is elected to a four-year term. Presently, the Governor of Massachusetts is Edward J. King, a Democrat from Winthrop. Governor King was elected to office in November, 1978. Before becoming Governor, he served as President of the New England Council and as Comptroller, Secretary-Treasurer, and Executive Director of the Massachusetts Port Authority. The Governor appoints the heads of various departments and members of boards and commissions, prepares and submits the state budget to the General Court, vetoes bills, and initiates legislation. The Governor is Commander-in-Chief of the Massachusetts National Guard and President of the Governor's Executive Council. He is also empowered to submit executive branch reorganization plans to the General Court. If the reorganization plan is not disapproved by the General Court within sixty days after its submission, it has the force of law.

The Governor's address and his principal staff members are:

Governor Edward J. King

State House, Room 360

Boston, Massachusetts 02133

$617-727-3600$

Chief Secretary:

Legislative Aide:

Legal Aide:

Communications and Press:

Scheduling:

Appointments :

Special Advisor:

Correspondence:
Paul Buzzi

Jack McAlynn

Neil Lynch

Ron Brinn

Patricia Connelly

Jeanne Marie Boylan

Eric Jostrum

Mary Ellen Fitzpatrick 
Governor's Cabinet. The Governor's Cabinet was created by the General Court in 1971. The Secretaries are appointed by and directly accountable to the Governor for the administration of the departments and agencies under their jurisdictions. Each Secretary has the authority to review and act on financial and budgetary matters concerning the programs that they administer. Pertinent Cabinet Secretaries are:

John A. Bewick

Secretary of Environmental Affairs 100 Cambridge Street, 20th Floor Boston, MA 02202

617-727-9800

Joseph Fitzpatrick

Secretary of Energy Resources

73 Tremont Street, Room 700

Boston, MA 02108

617-727-4732
Charles Mahoney

Secretary of Human Services

State House, Room 109

Boston, MA 02133

617-727-8065

George A. Luciano

Secretary of Public Safety

1010 Commonwealth Avenue

Boston, MA 02215

$617-566-4500$

Barry Locke

Secretary of Transportation and Construction

One Ashburton Place, 16th Floor

Boston, MA 02108

Governor's Executive Council. The Governor's Executive Council is comprised of eight elected members, the Lieutenant Governor, and the Governor. The Governor, who is the presiding officer, has no rote.

The Council may be contacted at: ,

State House, Room 184

Boston, MA 02133

617-727-2795. 
The members of the Governor's Executive Council are:

Governor

Lieutenant Governor

Executive Council Members:
Edward J. King

Thomas P. O'Neill, III

\author{
Honorable John Britland \\ Honorable George F. Cronin, Jr. \\ Honorable Herbert L. Connelly \\ Honorable Peter L. Eleey \\ Honorable John F. Markey \\ Honorable Joseph A. Longone \\ Honorable Leo J. Turo \\ Honorable Edward M. O'Brien
}

Office of Federal-State Relations. This of fice monitors actions of the federal government that may directly affect Massachusetts. The Office of Federal-State Relations provides a mechanism to promote the interests of the Commonwealth by influencing the direction of proposed federal legislation, policy, and agency regulations. It seeks to obtain federal funds and works directly with state agencies to assist them in their relationships with the federal government. This is in the Office of the Governor.

Office of Federal-State Relations

State House, Room 259

Boston, MA 02133

617-727-7289 


\section{Executive Agencies}

\section{Executive Office of Environmental Affairs}

The Executive Office of Environmental Affairs was established to "serve as the principal agency...f for the protection and improvement of the quality of the environment of the Commonwealth and the resources which together constitute it, and the improvement of the public's opportunity to enjoy and exist healthily in that environment, by controlling the manmade despoilation of such resources and directing growth and development along planned lines which preserve for all time an ecologically sound and aesthetically pleasing balance of naturally-occurring resources."

The Office administers coastal zone management conservation services, environmental impact review, and law enforcement. The office has five departments: Department of Environmental Quality Engineering; Department of Environmental Management; Department of Food and Agriculture; Department of Fisheries, Wildlife, and Recreation Vehicles; and Department of Metropolitan District Commission. The Secretary of the Office of Environmental Affairs is:

John A. Bewick

100 Cambridge Street

Boston, Massachusetts 02202

$617-727-9800$

Department of Environmental Quality Engineering. The Department of Environmental Quality Engineering administers those regulatory programs for air, water, solid waste, and land use controls. The Department also performs regulatory functions designed to protect public health 
and provides technical advice to local communities and agencies. The Commissioner is:

Dr. Anthony Cortese

100 Cambridge Street, 20th Floor

Boston, MA 02202

$617-727-2690$

Division of Water Pollution Control. Contained within the Department of Environmental Quality Engineering is the Division of Water Pollution Control. The division establishes programs for the prevention, control, and abatement of water pollution. It is responsible for approving plans for the construction of waste disposal facilities and for inspecting existing facilities. The Director is:

Thomas McMahon

110 Tremont Street, 3rd Floor

Boston, MA 02108

$617-727-3855$

Division of Hazardous Waste. Also contained within the Department of Environmental Quality Engineering is the Division of Hazardous Waste. This division has the responsibility for developing criteria, standards, and requirements for handling hazardous wastes. The Division's authority encompasses the identification, treatment, storage, transportation, use and disposal of hazardous wastes. It monitors the impact of such materials and licenses collectors, haulers, and disposers of hazardous wastes. The Director is:

William Cass

600 Washington Street

Boston, MA 02111

617-727-0776 
Department of Public Health. The Department of Public Health is responsible for providing direct health services, maintaining surveillance over the health of the citizens of Massachusetts, and regulating health care facilities, consumer products, and food and drug processing. The Commissioner of the Department of Public Health is:

Alfred Frechette

600 Washington Street

Boston, MA 02111

$617-727-2700$

Environmental Health Division. Contained within the Department of Public Health is the Environmental Health Division. The Division contains six sections: Lead Poisoning, Radiation, Food and Drug, Sanitary Code, Fluoridation, Safe Drinking Water, and Hazardous Waste Control. The Director is:

Gerald S. Parker

600 Washington Street, Room 770

Boston, MA 02111

$617-727-2660$

Radiation Control Section--Contained within the Environmental Health Division is the Radiation Control Section. Most authority within the executive branch governing the installation, usage, handling, transportation, and storage of sources of radiation is in the Radiation Control Section. All X-ray units in Massachusetts must be inspected by and registered with this office. The Director is:

Robert M. Hallisey

600 Washington Street, Room 770

Boston, MA 02111

$617-727-6214$ 
Advisory Council on Radiation Protection. The Advisory Council on Radiation Protection consists of the Commissioner of Public Health, Commissioner of Labor and Industries, Commissioner of Public Safety, Commissioner of Administration, Personnel Administrator, Director of Civil Defense, and six persons appointed by the Governor. The Council meets at least twice yearly. It makes recommendations to the Governor, General Court, and various departments concerning ionizing radiation. The Council submitted to Governor King a report entitled: Low-Level Radioactive Waste Management in Massachusetts in November, 1980. A copy of the report is contained in Appendix A of this handbook. The Advisory Council on Radiation Protection may be contacted through Mr. Robert Hallisey of the Radiation Control Section. The members of the Council are:

$\begin{array}{lc}\text { Constantine J. Maletskos, Chairman } & \text { Frank Archibald } \\ \text { Colburn Street } & \text { Department of Labor } \\ \text { Gloucester, MA } 01930 & \text { and Industries }\end{array}$

$617-283-2339$

Manson Benédict

Massachusetts Institute of Technology

Paul Cahill

Civil Defense Agency

Edward Hanley

Executive Office of Administration and Finance

James R. N1chols

Nichols and Pratt
Patrick Scavotto

West Roxbury, MA

Carlisle Smith

Department of Public Safety

John Marchant

Division of Personnel Administration 
State Geologist. The State Geologist is responsible for providing state agencies with information and advice on matters relating to groundwater, exploration of coal resources and offshore oil, soil formation, and mineral resources. The State Geologist is:

Joseph A. Sinnoter

1-11 Winter Street

Boston, MA

$617-727-4796$

4.3b. LEGISLATIVE BRANCH

The official name of the Massachusetts Legislature is the General Court. The General Court consists of a Senate, which has 50 members, and a House of Representatives, which has 160 members. All legislators are elected to two-year terms. The General Court convenes annually on the first Wednesday in January and adjourns when both houses agree and request the Governor and the Governor's Council to adjourn the session. The General Court is empowered to enact laws, administer oaths of office, levy an income tax, charter cities, and authorize the state to obtain land.

Table 4.1 provides a list of legislative information sources, and Map 4.1 illustrates the Massachusetts Congressional Districts .

\section{Senate}

The membership of the Massachusetts Senate consists of 31 Democrats, 7 Republicans, 1 Independent and 1 vacancy. A roster of Senate members, including their political affiliations, hometowns, and State House phone numbers, is on pages $4-23$ and $4-24$. 
TABLE 1. LEGISLATIVE INFORMATION SERVICES

Type of Information

General information

Information pertaining to

the previous years' legis-

lative activity and laws

Information on pending

legislation

Information on bills

pending before the Governor

To obtain copies of bills

To obtain copies of laws
Source

Central Exchange

State House

News Service

Senate Clerk's Office

House Clerk's Office

Governor's Office

Legislative Document

Room

State House Bookstore
$727-2416$

Phone Number

(617) $727-2121$

$727-2476$

$727-2356$

$727-3600$

$727-2349$

$727-2834$ 


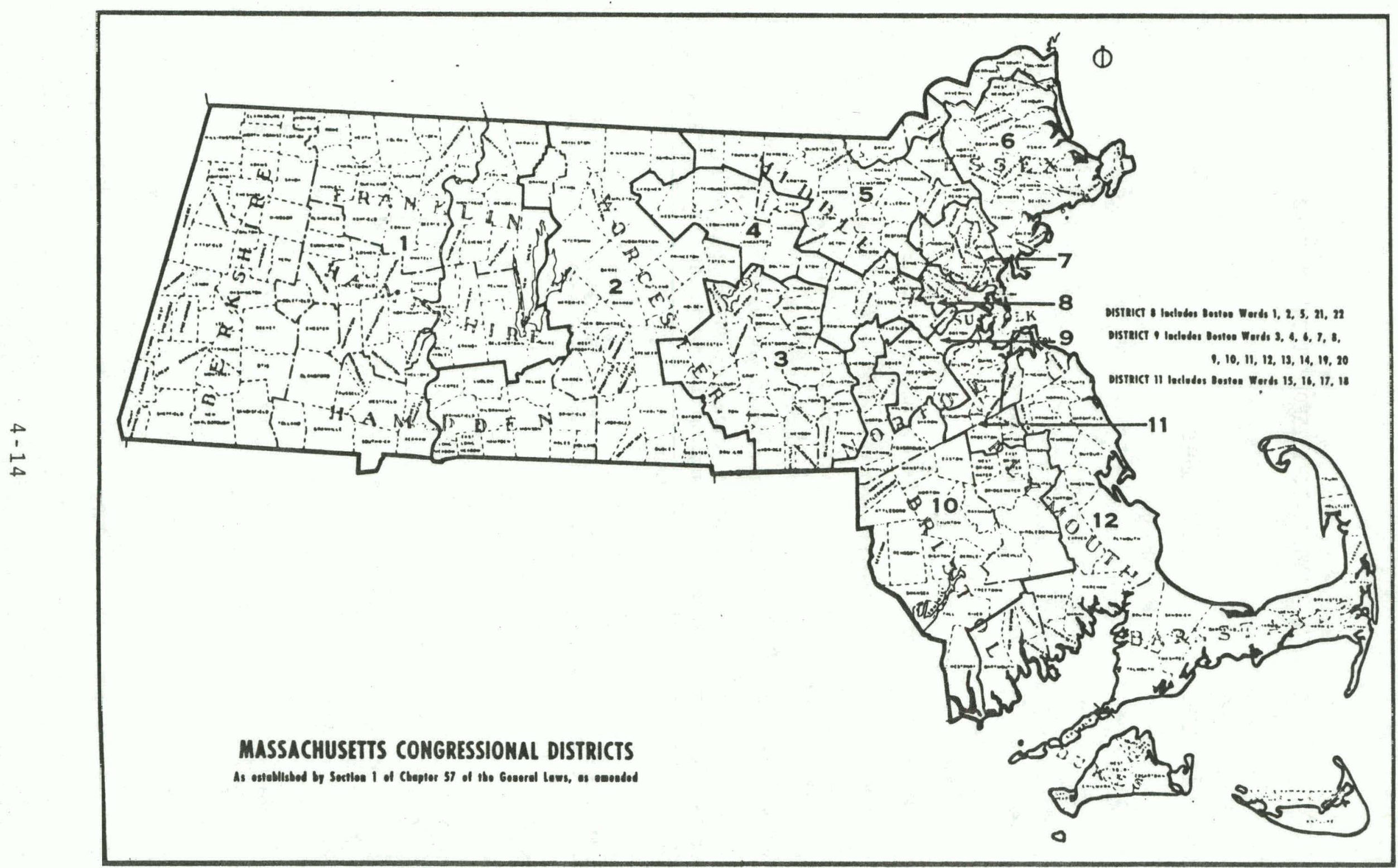

Map 4.1 Massachusetts Congressional Districts 
Senate Leadership. The presiding officer of the Senate is the President, who is elected by the members of the Senate. The President appoints the Majority and Assistant Majority Leaders, decides on all questions of order, appoints the members and chairmen of the Senate Standing Committees, and serves as the chairman of the Senate Rules Committee.

The officers of the Senate are:

President:

Majority Leader:

Assistant Majority Leader:

Minority Leader:

Assistant Minority Leader:

Assistant Minority Leader:

Assistant Minority Leader:
William M. Bulger ( $D$, Boston)

Daniel J. Foley (D, Worcester)

Mary L. Fonseca (D, Fall River)

John F. Parker ( $R$, Taunton)

David H. Locke ( $R$, Wellesley)

John F. Aylmen ( $R$, Barnstable)

Robert A. Hall ( $R$, Fitchburg)

Committee Structure. Joint Standing Committees bear the major burden of conducting hearings and recommending action on legislative proposals. Joint Standing Committees are composed of 6 Senators and 11 Representatives. The President appoints the Senate members of the Joint Standing Committees and a Senate Chairman for each committee. Joint Standing Committees must issue their final reports not later than the fourth Wednesday in Aprii on all matters referred to them on or after that date. All meetings are open to the public unless voted otherwise by a majority of the committee members. Those Joint Standing Committees that may be relevant to radioactive waste management or radiation control are given on pages 4-17 through 4-22.

\section{House of Representatives}

The membership of the Massachusetts House of Representatives comprises 128 Democrats, 31 Republicans, and 1 Independent. A roster of House members, including their political affiliations, hometown, and State House phone numbers, is given on pages 4-25 through 4-30. 
House of Representatives Leadership. The presiding officer of the House is the Speaker, who is elected by the members of the House. The officers of the House of Representatives are:

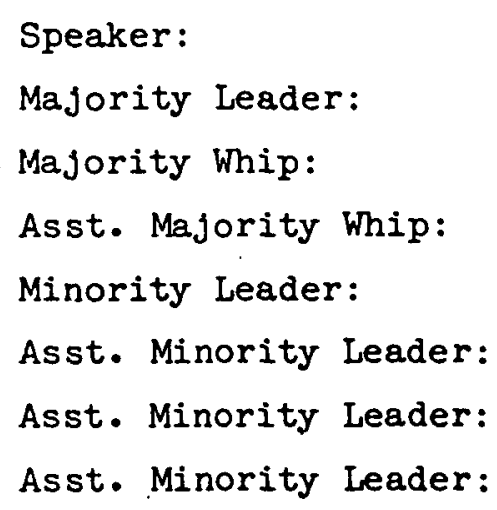

\author{
Thomas W. McGee (D, Lynn) \\ George Keverian (D, Everett) \\ John E. Murphy, Jr. (D, Peabody) \\ Vincent J. Piro (D, Somerville) \\ William G. Robinson ( $R$, Melrose) \\ Edward W. Connelly ( $R$, Agawam) \\ Iris $K$. Holland ( $R$, Longmeadow) \\ Andrew H. Card, Jr. (R, Holbrook)
}

Committee Structure. Joint Standing Committees bear the major burden of conducting hearings and recommending action on legislative proposals. Joint Standing Committees are composed of 6 Senators and 11 Representatives. Those Joint Standing Committees that may be relevant to radioactive waste management or radiation control are given on pages 4-17 through 4-22. 
Energy. The Energy Committee considers all matters concerning the exploration, exploitation, and development of energy sources. This includes the siting of energy facilities and other related matters that may be referred to the Committee.

Chairmen:

Sen. Michael LoPresti, Jr.

(D, Boston)

Rep. Thomas C. Norton

(D, Fall River)

\section{Senators--}

John W. Olver

(D, Amherst)

Sharon M. Pollard

(D, Methuen)

John P. Burke

(D, Holyoke)

Louis P. Bertonazi

(D, Milford)

Paul D. Harold

(D, Quincy)

\section{Representatives--}

Angelo R. Cataldo

James G. Collins

Charles F. McNally

Timothy M. Rourke

John H. Flood

Steven Angelo

Allan R. Chiocca

Susan D. Schor

Bruce N. Freemen

Walter A. DeFilippi
(D, Revere)

(D, Amherst)

(D, Franklin)

(D, Lowell)

(D, Canton)

(D, Saugus)

(D, Bridgewater)

(D, Newton)

(R, Chelmsford)

( $R$, West Springfield) 
Federal Financial Assistance. This Committee considers all matters regarding the receipt of federal aid, joint resolutions memorializing the United States Congress or other federal agencies or officials, and other pertinent matters.

Chairmen:

Francis D. Doris

(D, Revere)

Dorls Bunte

(D, Boston)

\section{Senators--}

Bill Owens

Gerald D'Amico

John G. King

Louis P. Bertonazzi

Peter C. Webber
(D, Boston)

(D, Worcester)

(D, Danvers)

(D, Milford)

( $R$, Great Barrington)

\section{Representatives--}

Thomas M. Finneran

William R. Keating

Walter E. Bickford

James R. Miceli

Kenneth M. Lemanski

Peter G. Trombly

Susan D. Schur

Howard, C. Cahoon

Steven D. Pierce

Peter Forman
(D, Boston)

(D, Sharon)

(D, Berlin)

(D, Wilmington)

(D, Chicopee)

(D, Waltham)

(D, Newton)

( $R$, Chatham)

( $R$, Westfield)

( $R$, Plymouth) 
Health Care. The Health Care Committee considers all matters concerning health care programs and regulation of the health care system including rate setting, licensing of health facilities and personnel, and other related matters.

Chairmen:

Sen. Edward L. Burke

(D, Framingham)

Rep. Theodore J. Aleixo, Jr.

(D, Taunton)

\section{Senators:}

Louis P: Bertonazzi

(D, Milford)

Samuel Rocondi

(D, Winchester)

John G. King

(D, Danvers)

Philip L. Shea

(D, Lowell)

Peter C. Webber

( $R$, Great Barrington)

\section{Representatives--}

Andrew J. Rogers, Jr.

(D, Framingham)

Elizabeth N. Metayer

(D, Braintree)

James A. Whitney

(D, Dudley)

Thomas K. Lynch

(D, Barnstuble)

Stephen J. Karol

(D, Attleboro)

John M. Menard

(D, Somerset)

Walter D. Silveira

(D, Fairhaven)

Thomas J. Vallely

(D, Boston)

Argeo P. Cellucci

( $R$, Hudson)

James T. Harrington

( $R$, Holden) 
Natural Resources and Agriculture. This Committee considers all matters pertaining to natural resources and the environment; air, water and noise pollution; solid waste disposal; sewerage; agriculture; and other related matters.

Chairmen:

$\begin{array}{ll}\text { Sen. Carol C. Amick } & \text { (D, Bedford) } \\ \text { Rep. William P. Nagle, Jr. } & \text { (D, Northampton) }\end{array}$

Senators--

Edward I Burke

(D, Framingham)

Robert D. Wetmore

(D, Barre)

Philip L. Shea

(D, Lowell)

Francis D. Doris

(D, Revere)

Peter C. Webber

( $R$, Great Barrington)

\section{Kepresentatives--}

Jos eph S. Scelsi

Nickolas Lambros

Henry R. Grenier

Melvin H. King

Roger R. Goyette

Walter E. Bickford

Nicholas J. Costello

Thomas K. Lynch

Richard R. Silva

Lucile P. Hicks
(D, Pittsfield)

(D, Dracut)

(D, Spencer)

(D, Boston)

(D, New Bedford)

(D, Berlin)

(D, Amesbury)

(D, Barnstable)

( $R$, Gloucester)

( $R$, Wayland) 
Public Safety. This Committee considers all matters relevant to public safety, including civil defense, motor vehicle laws, and other related matters.

Chairmen:

$\begin{array}{ll}\text { Sen. John P. Burke } & \text { (D, Holyoke) } \\ \text { Rep. Thomas P. White } & \text { (D, Worcester) }\end{array}$

Senators--

John A. Brennan, Jr. (D, Malden)

William Q. MacLean, Jr. (D, Fairhaven)

Martin T. Reilly (D, Springfield)

Edward P. Kirby ( $R$, Whitman)

George Bachrach (I, Watertown).

\section{Representatives--}

$\begin{array}{ll}\text { George J. Bourque } & \text { (D, Fitchburg) } \\ \text { Angelo Picucci } & \text { (D, Leominster) } \\ \text { Nickolas Lambros } & \text { (D, Dracut) } \\ \text { William A. Carey } & \text { (D, Easthampton) } \\ \text { Roger R. Goyette } & (D, \text { New Bed ford ) } \\ \text { Roger L. Tougas } & (D, \text { Dartmouth) } \\ \text { William E. Moriarty } & (D, \text { Ware) } \\ \text { Stephen W. Doran } & (D, \text { Lexington) } \\ \text { Kevin Poirier } & (R, \text { North Attleborough) } \\ \text { Robert L. Howarth } & (R, \text { Springfield) }\end{array}$


Transportation. This Committee considers all matters concerning the development, operation, regulation, and control of all modes of transportation. Also within the Transportation Committee's purview is the setting of tollrates for tunnels and bridges.

Chairmen:

Sen. John B. Walsh

(D, Boston)

Rep. Louis R. Nickinello

(D, Natick)

\section{Senators--}

John W. OIver

(D, Amherst)

Samuel Rotondi

(D, Winchester)

Carol C. Amick

(D, Bedford)

Robert C. Buell

( $R$, Bosford)

Paul D. Harold

(D, Quincy)

\section{Representatives--}

Jeremiah F. Cahir

Paul W. White

Elizabeth N. Metayer

Mary Jane Gibson

George J. Bourque

Alfred A. Minahan, Jr.

David B. Cohen

Sherman W. Saltmarsh, Jr.

John Gray
(D, Bourne)

(D, Boston)

(D, Braintree)

(D, Belmont)

(D, Fitchburg)

(D, Wakefield)

(D, Newton)

( $R$, Winchester)

( $R$, Groveland) 
ROSTER OF SENATORS

$1981-82$ SESSION

This roster provides each Senator's name, political affiliation and hometown.

Name

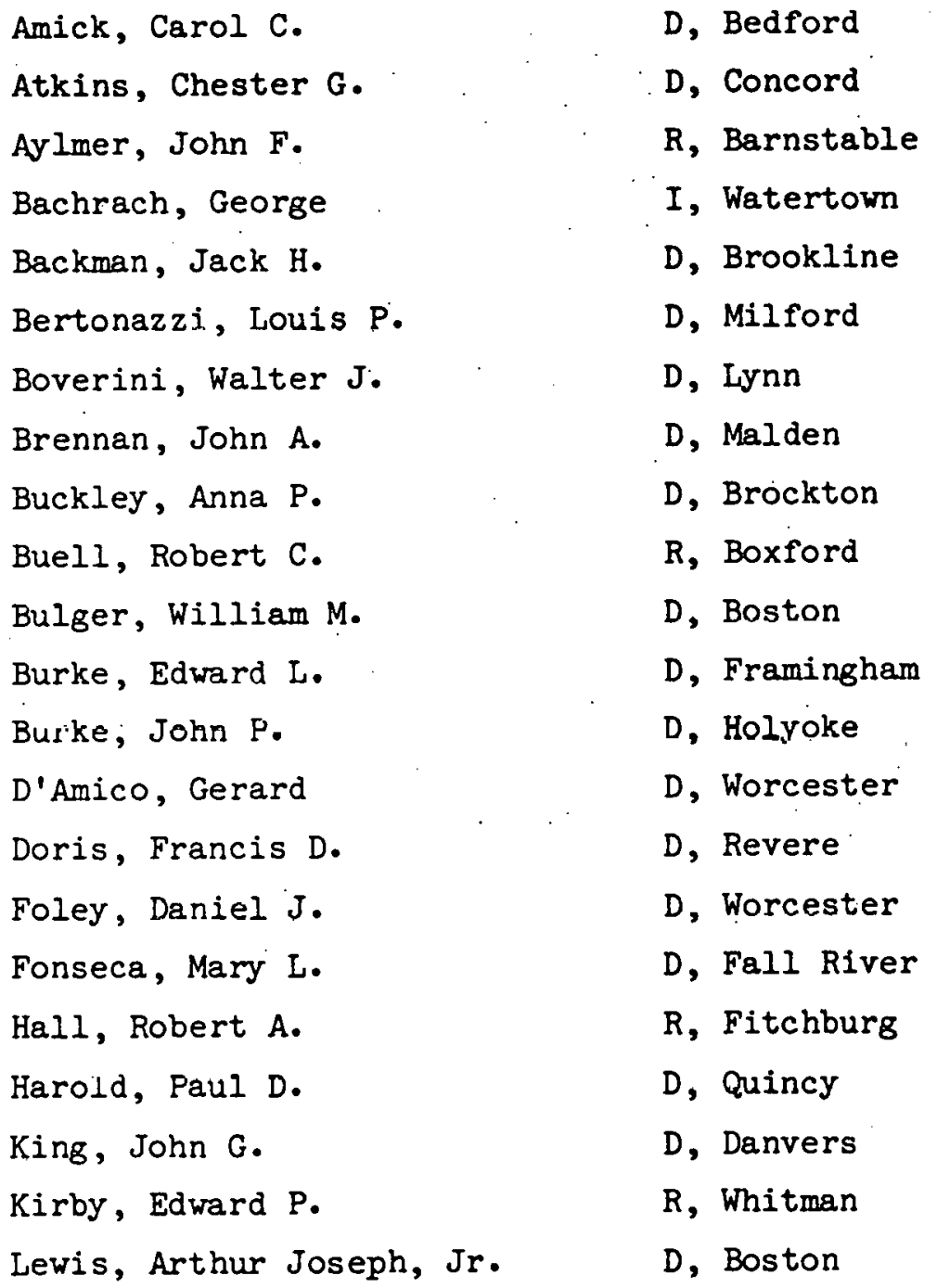

Political Affiliation

and Hometown

D, Bedford

$R$, Barnstable

$D$, Brookline

D, Milford

D, Lynn

, Malden

Brockton

ford

D, Holyoke

D, Revere

D, Worcester

D, Fall River

, Fitchburg

, Quincy

, Danvers

D, Boston 
Locke, David H.

LoPresti, Michael, Jr.

MacLean, William Q., Jr.

McGovern, Patricia

McKenna, Denis L.

McKinnon, Allan R.

Olver, John W.

Owens, Bill

Parker, John F.

Pollard, Sharon M.

Reilly, Martin T.

Rotondi, Samuel

Shea, Philip L.

Sisitsky, Alan D.

Timilty, Joseph F.

Walsh, Joseph B.

Webber, Peter C.

Wetmore, Robert D.
$R$, Wellesley

D, Boston

D, Fairhaven

$D$, Lawrence

D, Somerville

$D$, Weymouth

$D$, Amherst

D, Boston

$R$, Taunton

$D$, Methuen

D, Springfield

D, Winchester

D, Lowell

D, Springfield

D, Boston

D, Boston

$R$, Great Barrington

D, Barre 
This roster provides each Representative's name, political affiliation and hometown.

Name

Aguiar, Antone S., Jr.

Aleixo, Theodore J., Jr. Alexander, Lawrence $\mathrm{R}$. Ambler, Robert B. Angelo, Stephen Asiaf, Peter George Barrett, Michael J. Bassett, Timothy A. Benson, William D. Bickford, Walter E. Blanchette, Kevin P. Bohigian, Robert J. Bolling, Royal L., Jr. Bourque, George J. Brownell, Thomas F. Buglione, Nicholas J. Bunte, Doris Businger, John A. Cahir, Jerewiah F. Cahoon, Howard C., Jr. Canavan, Ellen M. Card, Andrew H., Jr. Carey, William A. Cataldo, Angelo R.
Political Affiliation

and Hometown

D, Swansea

D, Taunton

D, Marblehead

$D$, Weymouth

$D$, Saugus

D, Brockton

D, Reading

$D$, Lynn

D, Greenfield

D, Berlin

$D$, Lawrence

D, Worcester

D, Boston

D, Fitchburg

D, Quincy

D, Methuen

D, Boston

D, Brookline

D, Bourne

$R$, Chatham

$R$, Needham

$R$, Holbrook

D, Easthampton

D, Revere 


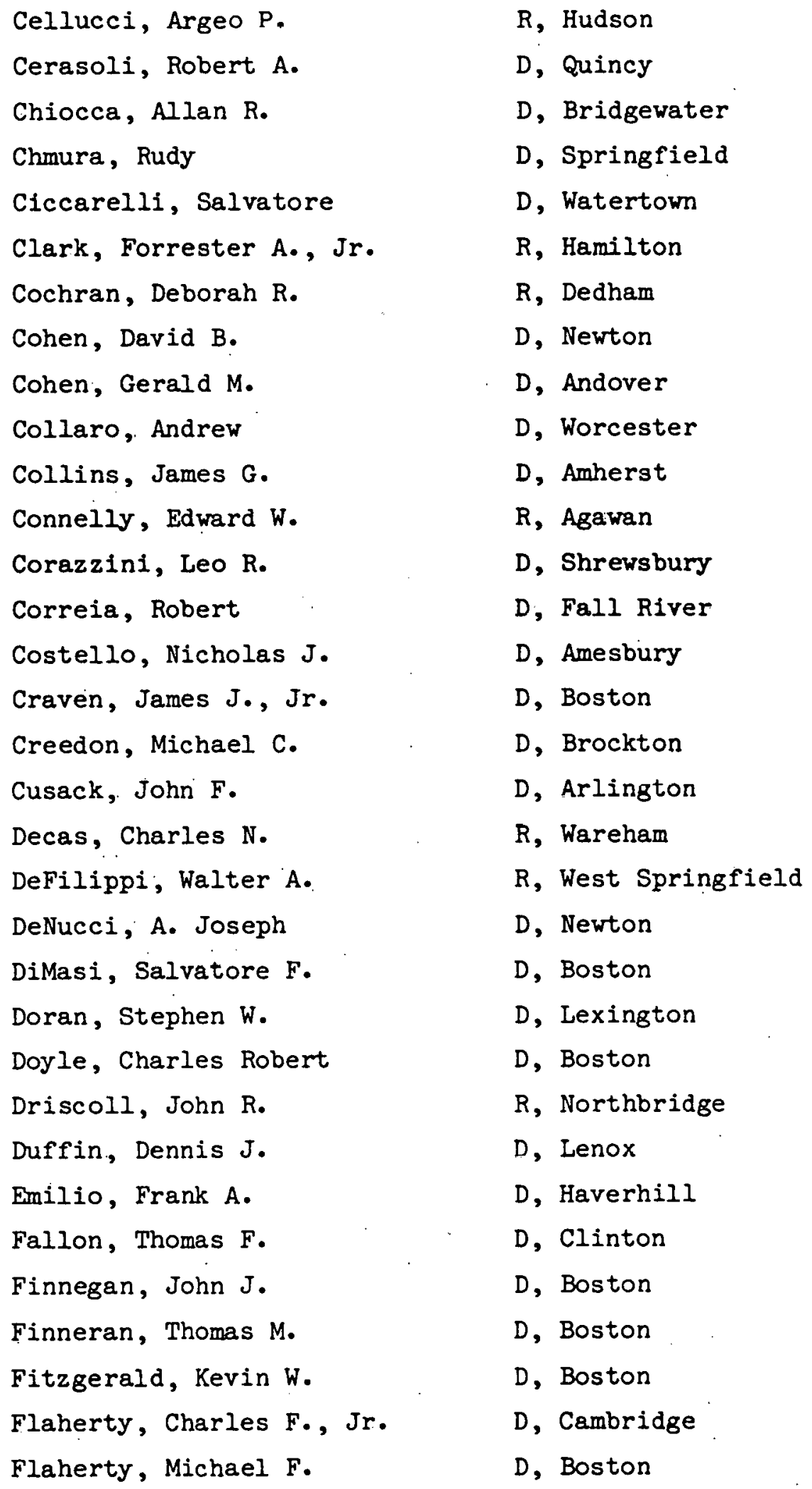




\begin{tabular}{|c|c|}
\hline Flood, John H. & D, Canton \\
\hline Flynn, William J., Jr. & $D$, Hanover \\
\hline Forman, Peter & $R$, Plymouth \\
\hline Freeman, Bruce N. & $R$, Chelmsford \\
\hline Gallagher, Thomas M. & D, Boston \\
\hline Galvin, William F. & D, Boston \\
\hline Gibson, Mary Jane & D, Belmont \\
\hline Glodis, William J., Jr. & D, Worcester \\
\hline Goyette, Roger R. & $D$, New Bedford \\
\hline Graham, Saundra & D, Cambridge \\
\hline Gray, Barbara E. & $R$, Framingham \\
\hline Gray, John & $R$, Groveland \\
\hline Greenhalgh, Haden G. & $R$, Harwich \\
\hline Grenier, Henry R. & $D$, Spencer \\
\hline Harrington, James T. & $\mathrm{R}$, Holden \\
\hline Healy, Jonathan L. & $R$, Charlemont \\
\hline Hermann, Joseph N. & $D$, North Andover \\
\hline Hicks, Lucile P. & $R$, Wayland \\
\hline Holland, Iris $\mathrm{K}$. & $R$, Longmeadow \\
\hline Howarth, Robert L. & R, Springfield \\
\hline Howe, Marie E. & D, Somerville \\
\hline Johnston, Philip W. & D, Marshfield \\
\hline Jordan, Raymond A., Jr. & D, Springfield \\
\hline Karol, Stephen J. & $\tilde{\mathrm{D}}$, Attleboro \\
\hline Keating, William R. & D, Sharon \\
\hline Keverian, George & D, Everett \\
\hline King, Melvin H. & D, Boston \\
\hline Kollios, Paul & D, Millbury \\
\hline LaFontaine, Raymond M. & $D$, Gardner \\
\hline Lambros, Nickolas & D, Dracut \\
\hline Lawrence, Denis & $D$, New Bedford \\
\hline Lawton, Mark E. & D, Brockton \\
\hline LeLacheur, Edward A. & D, Lowell \\
\hline
\end{tabular}




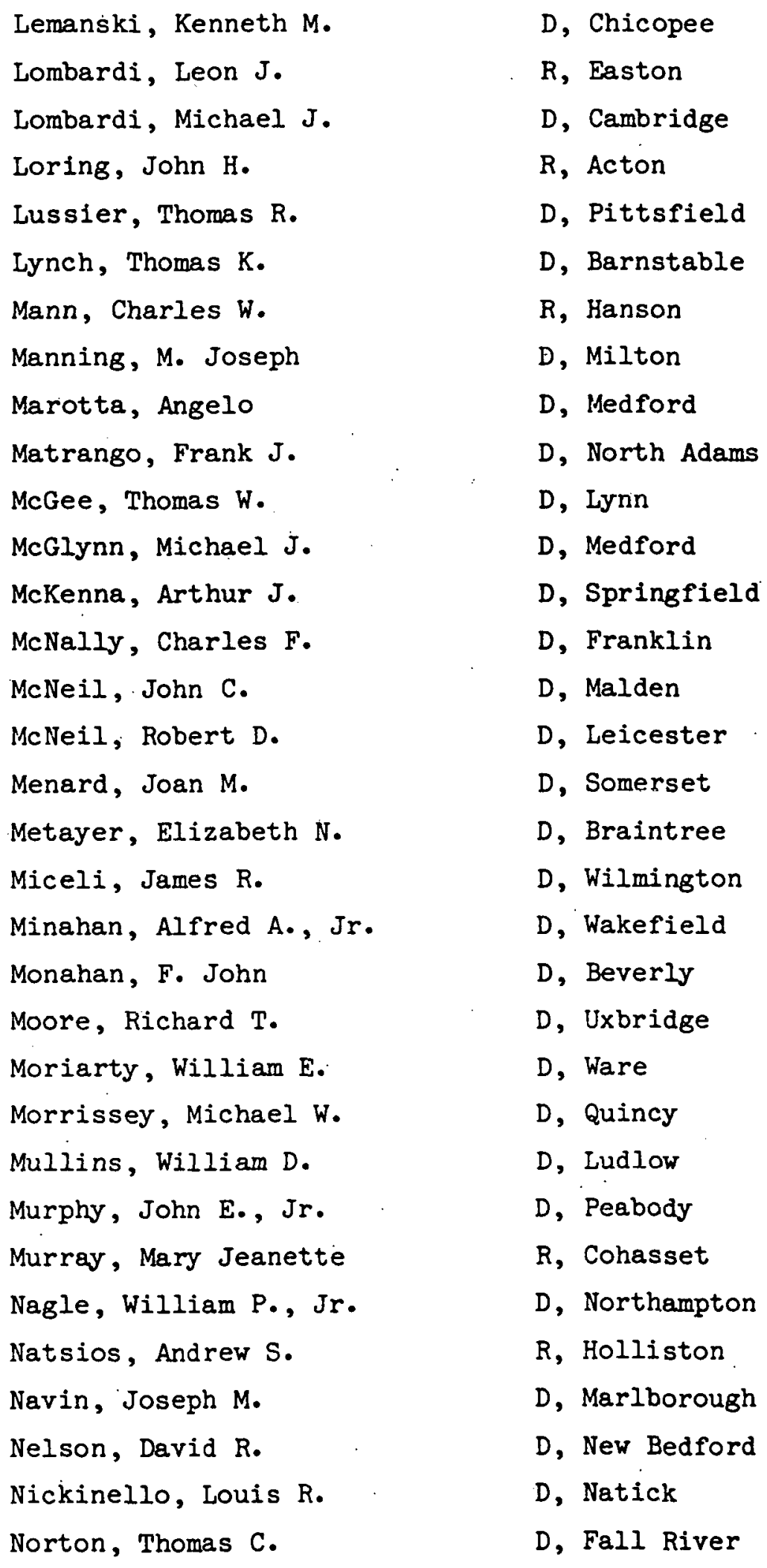




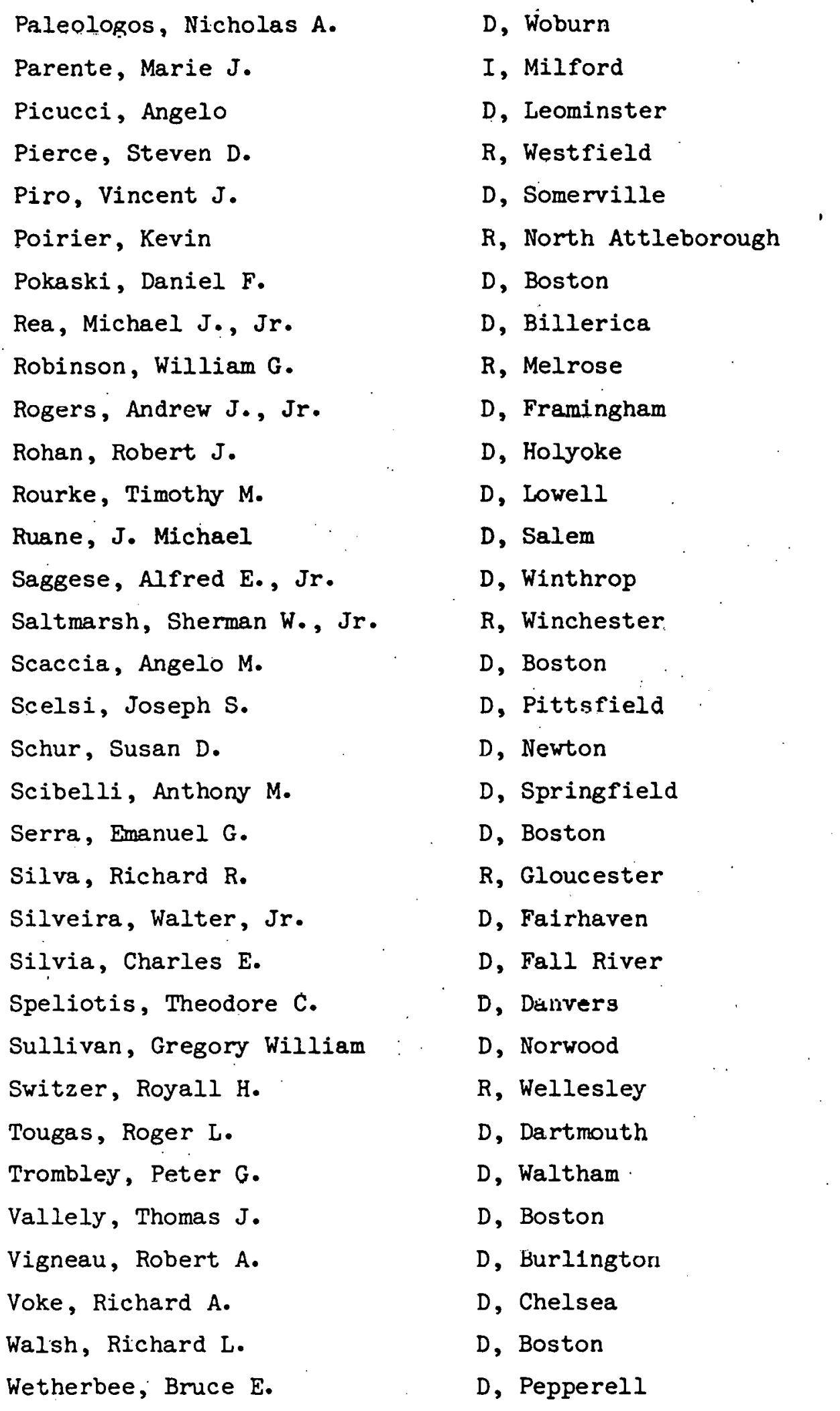



White, Thomas B.
D, Worcester
White, W. Paul
D, Boston
Whitney, A. James
D, Dudley
Woodward, Francis H.
D, Walpole 
4.3c. JUDICIAL BRANCH

The Massachusetts courts comprise seven Departments that are supervised by the State Trial Court. The Justices of the seven departments select one of their members for a seven-year term as Chief Administrative Justice. The Chief Administrative Justice, with the approval of the State Supreme Judicial Court, appoints an Administrator of Courts for the Trial Courts to assist in the management of the court system.

The Supreme Judicial Court designates one Justice from each of the seven departments as the Administrative Justice for their respective departments. Although the term of the Administrative Justices is five years, initial appointees have life tenure as Administrative Justices.

The Supreme Judicial Court

A Chief Justice and six Associate Justices sit on the bench of the Supreme Judicial Court, which is located in Boston. The Supreme Judicial Court is the final authority on the interpretation of the Constitution of Massachusetts and the laws enacted by the General Court (Legislature). The Supreme Court is authorized by the Consitution to render advisory opinlons on important questions of law when requested by the Governor, the General Court, or the Executive Council.

The Appeals Court

The Appeals Court, consisting of a Chief Justice and five Associate Justices, has the same jurisdiction as the Supreme Judicial Court. Although the Appeals Court is a court of final resort, the Appeals Court may refer cases that raise significant legal issues or substantial constitutional questions, directly to the Supreme Judicial Court. 


\section{District Courts}

The District Courts, referred to as the "People's Courts," are courts of general Jurisdiction. The District Courts are the courts of origin for most cases concerned with civil, criminal and small claims matters.

\section{The Superior Court}

The Superior Court is a a circuit court which hears cases in 21 locations throughout the State. The Superior Court may preside over criminal cases, civil cases, or cases in equity. A citizen may petition the Superior Court to order a state or local government official to allow that citizen access to public records. A citizen who suspects that a local government official is about to spend money illegally may present the Superior Court with a petition signed by 10 taxpayers requesting a restraining order on that official. If the official involved is a state official, 24 signatures are required.

\section{The Land Court}

I'he Land Court has specialized jurisdiction in the registration of real estate titles and other matters relating to the ownership or use of real estate. In each Massachusetts county, there is a separate section in the office of the Registry of Deeds for records of the Land Court. All ownership and boundary disputes are adjudicated in this court.

\section{3d. RELEVANT STATUTES AND REGULATIONS}

In this section the legislation relevant to low-level radioactive waste management or radiation control is summarized, followed by a summary of implementing regulations. The full text of all Massachusetts statutes and regulations cited in this section is included in Appendix B. 
Chapter 474, Section 5B, of the General Laws of Massachusetts.

This Section authorizes the Department of Health to require registration of sources of ionizing and nonionizing radiation. It also empowers the Department to promulgate rules and regulations for the control of radiation hazards associated with the use, transportation, storage, packaging, sale, distribution, production, and disposal of radioactive materials.

Department of Public Health Regulations. The Massachusetts Department of Public Health has promulgated "Rules and Regulations to Control the Radiation Hazards of Radioactive Materials and of Machines Which Emit Ionizing Radiation." The purpose of these rules is to protect the Massachusetts citizenry from hazards associated with the use, transportation, storage, packaging, sale, distribution, production, and disposal of radioactive materials (Section A.I).

Radioactive materials that do not exceed the quantities set forth in Table 1 of Section D. 1 and which do not result in exposure levels exceeding 5 milition per year are exempt from these regulations. Also exempt are radioactive materials that are transported intrastate in conformance with the regulations of any agency which maintains Jurisdiction over interstate transportation, providing that such regulations meet the ionizing radiation protection requirements of the Department of Health (Section D).

All radioactive material must be kept or stored in a manner that provides reasonable ussurance that no individual will receive an absorbed dose in excess of the Radiation Protection Guides outlined in Table 2 of the regulations. All radioactive material must be stored in a manner that will prevent unauthorized removal from the place of storage (Section $\mathrm{J}$ ). 
All work performed with radioactive material mast be conducted in a manner which minimizes the possibility of contamination that would result in an individual receiving an absorbed dose of radiation in excess of the Radiation Protection Guides. All persons who work with radioactive material not contained in a sealed source must have immediate access to instruments suitable for determining and measuring contamination levels (Section $K$ ).

The presence of ionizing radiation in an area must be indicated by conspicuous signs that bear the radiation caution symbol and the appropriate wording specified in Table 4 of the regulations. All containers used for the transfer or storage of radioactive material must indicate the kind and quality of material and the name of the person responsible for that material (Section $L$ ).

No radioactive terial may be released into the air or water or buried in a manner which would result in individual exposure levels in excess of the Radiation Protection Guides. No radioactive material which occur's in a quantity greater than that stated in Table 1 of the regulations may be disposed of by burial or stored in or on unenclosed ground without first obtaining the approval of the Department of Health (Section M).

Hazardous Waste Regulations. The Massachusetts Hazardous Waste Board has promulgated regulations that specify the manner in which hazardous substances may be handled and disposed of.

\section{Handling of Hazardous Wastes--No person may dispose of a} classified hazardous waste at a site within Massachusetts unless the Division of Water Pollution Control has approved of the disposal. No person may dispose of hazardous waste at an off-shore disposal site unless that site has been approved by the Division of Water Pollution Control. In no instance may radioactive material be dumped in the 
waters of the Commonwealth of Massachusetts ( 315 Code of Massachusetts Regulations, Section 2.03).

Disposal Methods and Locations--Disposal of radioactive material may be permitted at an offshore site if that site has been designated by the Division of Water Pollution Control. Disposal may also be permitted at those land-sites licensed by the Division (315 CMR 2.05).

Licensing--Any person who wishes to handle or dispose of hazardous waste must submit an application for a license to the Division of Water Pollution Control (315 CMR 2.06).

\section{Chapter 6, Section 91, of the General Laws of Massachusetts.}

This section directs various state agencies to continuously monitor laws and regulations administered by them which are relevant to radioactive material. When appropriate, the agencles are further directed to recommend new laws or regulations or changes in the current laws and regulations. Seven agencies are assigned specific areas of responsibility:

- Department of Public Health - hazards to public health and safety

- Department of Labor and Industries - hazardous working conditions

- Department of Industrial Accidents - claims for injuries arising from accidents

- Department of Public. Works - transportation of radioactive material

- Department of Public Utilities - transportation of radioactive materials by intrastate common carriers and in the development of industrial or commercial uses of radioactive material 
- Division of Insurance - insurance of persons and property from hazards associated with atomic development

- Department of Environmental Affairs - hazards of natural resources

Transportation Regulations. These regulations, governing the transportation of hazardous materials in commerce on state highways, were promulgated by the Department of Public Works. The regulations are applicable to all common, contract, and private carriers of hazardous materials on state highways of Massachusetts. These regulations establish comprehensive regulation of shipping, packing, marking, labeling, placarding, handling, and transportation of hazardous materials in commerce (Title 720 , Code of Massachusetts Regulations Sections 8.01 and 8.02 ).

The regulations promulgated by the United States Department of Transportation regarding the transportation of hazardous materials that are adopted by Massachusetts are:

Title 49, Chapter 1 of the Code of Federal Regulations, Parts $171,172,173,177,178$, and 179 (720 CMR 8.03).

Massachusetts specifically excludes portions of the adopted federal regulations governing transportation of hazardous materials by air, water, rail, or pipeline. Also excluded are reporting requirements of 49 CFR 171.15 and 49 CFR 171.16 (720 CMR 8.05).

The Department of Public Works accepts any exception granted by the U.S. Department of Transportation under Title 49 of the Code of Federal Regulations, Section 107, Subpart B. Subpart B prescribes the procedures by which persons who are subject to the requirements of Subchapter C of Title 49, and 46 CFR Parts 64 and 146 may obtain administrative relief from the requirements of those regulations (720 CMR 8.06). 
Massachusetts Turnpike Authority. The Massachusetts Turnpike Authority allows radioactive shipments on the turnpike provided a permit is obtained from the Authority prior to the movement. Radioactive materials are prohibited from the Callahan and Sumner Tunnels in the Boston area.

\subsection{FEDERAL ACTIVITIES IN THE STATE OF MASSACHUSETTS}

The federal government does not operate any major nuclear facility in Massachusetts. Three sites in Massachusetts that may require action under the Formerly Utilized Sites Remedial Action Program are: the Watertown Arsenal site (approximately five miles west of. Boston); the Ventron Corporation site in Beverly (approximately 15 miles northeast of Boston); and the Shpack Landfill site in Norton (approximately 15 miles northeast of Providence, Rhode Island).

\subsection{LOCAL GOVERNMENT AUTHORITY}

\section{Cities and Towns}

C1ties and towns are the primary units of local government in Massachusetts; every square foot of the state lies. wlthin a city or town. These are the only units of government having legal power under the state constitution. The primary difference belween a town and a sity is that in the former, all of the inhabitants meet, deliberate, act and vote on the major issues; whereas under a city government, all this is done by representatives. Cities are governed by a variety of charters.

\section{Other Local Government Authorities}

There also exist a number of secondary agencies in the state with local government authority. These agencies vary in the degree of authority held as well as characteristics of authority and size. Among 
these are: Counties, Regional Districts, Home Rule and Housing Authorities. Counties have no power to legislate or levy taxes under Massachusetts law, and are therefore relatively weak.

Home Rule. In 1966, the Home Rule Amendment was adopted to "reaffirm the customary and traditional liberties of the people with respect to the conduct of their local government..." This amendment precludes the Legislature from interfering in local matters within certain limits and except in defined circumstances. No provision of any city or town charter may be inconsistent with any provision of the Constitution or a law enacted by the General Court in accordance with the provisions in the Home Rule Amendment.

Zoning. A municipality or town is empowered to adopt zoning ordinances or bylaws for the purpose of promoting the health, safety, convenience, morals, or welfare of its inhabitants. Cities have the power to "prohibit noxious trades within the municipality or any specified part thereof."

Public Health. The City Council or Town Representatives have the power to form a Board of Health. They. can sit on the board themselves or can appoint members. The Board of Health has broad plenary powers to regulate and prohibit health hazards. The Board has the power to adopt or amend existing regulations to prevent pollution or contamination of the atmosphere, however, it must first hold a public hearing, and secondly, receive the approval of the governor and city council. In addition, some cities have Air Pollution Districts which have the power to enforce rules and regulations adopted by the state. Cities must receive permission from the state to form Air Pollution Districts.

\subsection{CITIZEN ACTION}

The Constitution of Massachusetts provides two mechanisms for legislative action by citizens. Through popular initiative, a group 
of citizens may propose a bill for the General Court's consideration. If the General Court does not pass the bill, but the requisite number of voters sign a petition in favor of the bill, it must be put on the ballot at the next biennial election. A popular referendum is a procedure by which citizens may require a law to be placed on the biennial election ballot for voters' approval.

\title{
Public Interest Groups
}

The following list provides the names of some of the public interest organizations operating in Massachusetts. Addresses, telephone numbers, and individuals to contact are provided where available.

The League of Women Voters of Massachusetts. The Massachusetts League is a non-partisan organization of 10,000 members with chapters in 190 cities and towns. The League seeks to provide information to its members and the general public on a variety of issues, and supports issues that it has studied and found to be in the public interest. The address of the League is:

\author{
Barbra Fegan, President \\ Dana Duxbury, Natural Resources Coordinator \\ 120 Boylston Street \\ Boston, MA 02116 \\ 617-357-8380
}

The Union of Concerned Scientists. This organization studies the Impact of advanced technology on society and disseminates its findings through quarterly newsletters, newspaper and magazine articles, media appearances, and public speaking engagements. The Union is headquartered in Cambridge and has a branch office in Washington, D.C. The chairman of the Board of Directors of the Union of Concerned Scientists is Dr. Henry W. Kendall, a nuclear physicist at the Massachusetts Institute of Technology. 
Union of Concerned Scientists, Inc.

1384 Massachusetts Avenue

Cambridge, MA 02238

$617-547-5552$

Massachusetts Public Interest Research Group, Inc. The Massachusetts Public Interest Research Group (MASSPIRG) is an organization headquartered in Boston with 12 affiliated chapters throughout the state. MASSPIRG maintains a professional staff to coordinate citizen action, publishes MASSCITIZEN, a quarterly newsletter, and THE MASSPIRG REPORT, a semi-annual newsletter. This organization also maintains research and information files for use by its members.

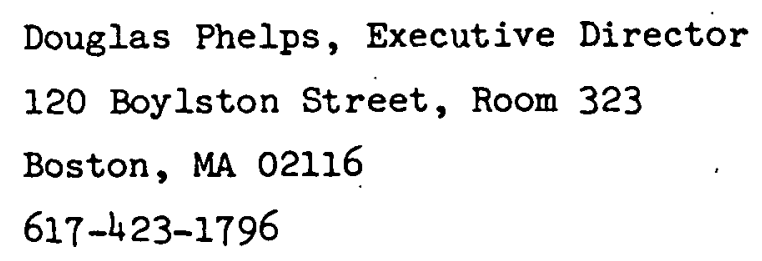

Massachusetts Voice of Energy. The Massachusetts Voice of Energy (MVOE) acts as a clearinghouse for information concerning the benefits of nuclear energy. MVOE also maintains a roster of speakers for public engagements and testifying at public hearings. The MVOE is headquartered in Boston and has three student chapters across the state.

Murray Campbell, President

Massachusetts Voice of Energy

100 Statler Office Building

Boston, MA 02116

617-482-3513 
Energy Policy Information Center. The Energy Policy Information Center (EPIC) acts as a clearinghouse for information on nuclear energy. EPIC also maintains a network of people interested in the nuclear waste issue called "Waste Watch." This organization is lobbying state governments to enact laws limiting the siting of nuclear waste disposal facilities.

\author{
Energy Policy Information Center \\ 3 Joy Street \\ Boston, MA 02114 \\ 617-523-0376
}

The No Nuclear News Collective. This is an independent collective providing a monthly cooperative clipping service. The NO NUCLEAR NEWS is a monthly publication presenting newspaper clippings and graphics relevant to nuclear energy. The publication also provides a "scoreboard" that reports nuclear accidents or incidents occurring in the preceding month.

No Nuclear News

C/O The Boston Clamshell Coalition

595 Massachusetts Avenue

Cambridge, MA 02139

The New England Coalition on Nuclear Pollution Inc. 'Ihe Coal1tion maintains a "mobile energy van" which provides presentations and literature on nuclear energy, models and displays of alternate energy sources, and other materials to illustrate alternative technologies. The Coalition maintains a roster of "Science Advisors" to speak on nuclear power issues. The Coalition maintains a resource center that provides books, documents, and other research material, and operates a film rental library containing flims such as "Danger Radioactive Waste," an NBC documentary highlighting military and civilian radioactive waste problems. 
Headquarters :

New England Coalition on Nuclear Pollution, Inc.

Box 637

Brattleboro, VT 05301

802-257-0336

Massachusetts office:

New England Coalition on Nuclear Pollution, Inc.

C/O Elizabeth Gage

5 Moody Street

Northfield, MA 01360

Boston Clamshell Coalition. This organization disseminates information on nuclear energy issues. The Coalition also organizes activities such as a planned "confrontational teach-in" at one of Boston Edison's downtown building lobbies.
Boston Clamshell Alliance
595 Massachusetts Avenue
Cambridge, MA 02139
617-661-6204

Coalition for Direct Action at Seabrook. The Coalition for Direct Action at Seabrook (CDAS) originated as a task force formed within the Clamshell Alliance. The CDAS grew into a national coalition. Through "collective nonviolent direct action", the CDAS is committed to halting "nuclear proliferation" and the construction of nuclear energy facilities.

Coalition for Direct Action at Seabrook

C/O Boston Clamshell Coalition

595 Massachusetts Avenue

Cambridge, MA 02139 
There are a number of regional "Contract Groups" that maintain liaison with the CDAS; the Massachusetts organizations are:

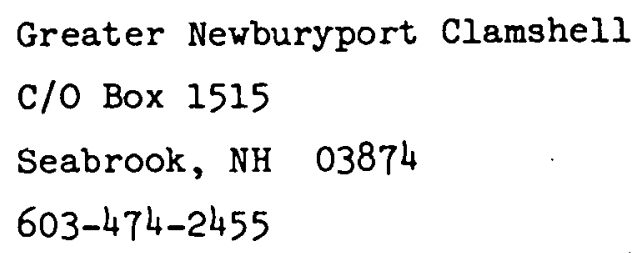




$$
\begin{aligned}
& \text { Brian Stewart, WECAN } \\
& \text { Box } 386 \text {, Chandler Village } \\
& \text { Worcester State College } \\
& \text { Worcester, MA } 01602 \\
& 617-752-1478
\end{aligned}
$$

Greenpeace of New England. This group is affiliated with the national Greenpeace Foundation. Greenpeace seeks to preserve and protect the environment.

$$
\begin{aligned}
& \text { Greenpeace New England } \\
& 286 \text { Congress Street } \\
& \text { Boston, MA } \\
& 617 / 542-7052
\end{aligned}
$$

The New England Chapter of the Sierra Club. The Sierra Club maintains a legal defense fund and has sued various federal agencies, such as the Department of Interior, in order to prevent actions that the Sierra Club believes are nnt. in the beot interests of lie euvironment.

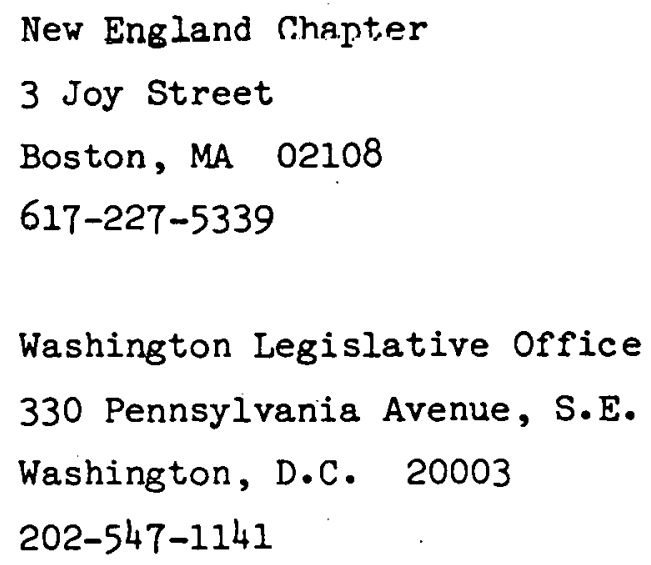

Mobilization for Survival. The Mobilization for Survival (MFS) is a national coalition of organizations which seek to channel public 
awareness into public action. The MFS is committed to obtaining a complete moratorium on all facets of nuclear power and weapons.

Mobilization for Survival

13 Sellars Street

Cambridge, MA

617-354-0008

National Headquarters:

3601 Locust Walk

Philadelphia, PA 19104

215-386-4875

The Women's International League for Peace Freedom. The United States Section of the League advocates an immediate halt to nuclear projects and stringent control of radioactive waste disposal.

Women's International League for Peace and Freedom

15 Sellars Street

Cambridge, MA

$617-734-4216$

\subsection{PRINTED MEDIA}

Appendix C contains newspaper articles published over a two-week period in either the "Boston Globe" or the "Boston Herald". These recent articles are supplemented by a larger number of newspaper clippings that were provided by Mr. Robert M. Hallisey, the Director of the Massachusetts Department of Public Health's Radiation Control Section. The clippings presented are all relevant to the broad area of nuclear energy. 
Appendix $D$ is a list of newspapers published or circulated in Massachusetts. The list provides the name of the paper, address and telephone number, area and size of circulation, and the press release deadline. 


\title{
5. SURVEY METHODOLOGY
}

A brief questionnaire was developed to solicit basic information necessary to generally characterize the low-level radioactive waste management practices in the State of Massachusetts. The survey form is presented in Exhibit I. The form is divided into five parts dealing with areas of:

\author{
I. Type of Facility \\ II. Disposal Method \\ III. Sources of Radioactive Waste \\ IV. Physical Form of Shipped Waste \\ V. Waste Quantity
}

The form was designed to provide information in a structured format (i.e., check off of predefined possible answers) wherever possible. In addition, the questions asked were limited to those which have a direct bearing on the overall characterization of practices within the State, rather than on the detailed characterization of each facility.

The name and address of each radioactivity licensee within the state were obtained from the Nuclear Regulatory Commission. A questionnaire package was malled to each licensee and consisted of a cover letter from the Massachusetts Radiation Control office, a transmittal letter (including brief instructions), a blank survey form, and a return envelope. The cover letter and transmittal letter are presented in Exhibits II and III, respectively.

As each response was received from the licensees, the information presented in Appendix A, List of Radioactive Material Licensees, was determined. A five-week response period was allowed, at which point all licensees not responding were classified as such and their "type 
of facility" classification determined from the licensee name, if possible. If not possible, they were classified as "unknown." The information provided by the licensee was then tabulated in the formats presented in Tables 1 through 11 of this Briefing Book.

\section{Overview}

A total of 365 radioactive material licenses are in effect in Massachusetts. Information on disposal practices was solicited from each license holder by a written questionnaire (see section below). Appendix A presents the name and address of each license holder; whether the licensee responded, indicated by " $Y$ " for yes and "N" for no; the type of facility; and whether they ship waste to a commercial disposal site.

The type of facility was classified as either Medical, Educational, Industrial, Power Reactor, or Governmental according to Part 1 of the survey form shown in Exhibit I. It should be noted that the Medical classification includes both medical education facilities and governmental medical facilities, that the Educational classification excludes medical education facilities, and that the Governmental classification excludes both medical and educational facilities. A service unit, such as a laboratory, was classified according to the type of facility to which it provides the service.

Of the 365 radioactive material users, contact was made with 164 , of which 77 indicated they ship waste to commercial disposal facilities. Table 1 presents a breakdown of license holders by type of facility, response to questionnaire, and number of shippers. The "percent of responses" was calculated as the number of respondents divided by the total number of licenses times 100. The "percent of shippers responding" 
was calculated as the number of respondents shipping waste divided by the total number of respondents in a facility classification times 100 .

Table 8 presents the on-site waste disposal practices employed, including disposal method other than shipment to commercial disposal facilities. In this table, the total of "number using" exceeds the total number of respondents due to use of several disposal practices by some facilities. It is believed that many facilities reported only the major disposal method used rather than all methods used and the data should be viewed with this qualiflcation in mind. The "percent of total respondents" value was calculated as the number of respondents in a "type of facility" classification reporting use of a method divided by the total number of respondents times 100. In addition, Table 3 presents the source of the radioactivity which eventually requires use of some disposal method. 


\section{Exhibit I}

\section{FADIOACTIVE WASTE SURVEY}

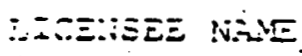

NFi:E DE ZACIIITY

STPEET RDERESS

こTY/STATE/こIミ

YEIEPHONE NO.

ZEASCN SUPPIYING INFORNATIOT

TITLE

DAPA I - TYPE OE EACIIITY

(GEECK THE GNE CPTESOPY WEICH IS MOST ADIIICEBLE)

$\therefore$ IICR INDUSTRTAI

( ) HOSFITÄ

( ) INCORPOIATES RADIOACTIVITY INTO PRODUCTS

() PEARMACEUTICAI MANUFACTURER ( ) USES PADIOACTIVITY IN PROCESS CONTROL

() MEDICAL SESEARCH/EDUCATION ( ) COMMERCIAL FOWER REACTOR

() DTFER. (SPEGIEY)

( ) OTIER (GEECIYY)

EDUCETIONAL

( ) UNIVERSITY

i) HIGH SCHOOL

( ) OTHER (SPECIEY)
GCVERNIENTAI (NON-MEDICAT OR EDUCATIONRL)
() FEDERAL
( ) MILITARYY
() STATE
( ) LOCAI

PARA II - DISPOSAL METHOD

CEECK EACH DISPCSEI METHOD UHICE YOU DO EMIOY

( ) SEIP TO COLAMERICII REPOSITORY

( ) RELEASE TO SEWER

( ) COMEINE WITK COMAON REFUSE

( ) VENT TO ATMOSPHERE

( ) BURY ON-SIME

( ) RETURN TO VENDOR

( ) DISTRIBUTE IN PRODUCT FORM

( ) NO WASTE GENERATED

( ) OTHER (SPECIFY)

$$
5-4
$$


VI:-: ON-SITE PROCESSING OF WASTE DO YOU EMPLOY?
i) NONE
( ) IECSANICAI COMPSCTION
( ) INCINERATION
( ) SOIIDIFICAMION OR EVAPORATION OF LIQUIDS
(.) hBSORPTION OF LIQUIDS
() OTHER (SFECIEY)

\begin{abstract}
FART V - WASTE QUANTITY
INDICATE TOTAI YEARLY VOLURE (IN CUBIC FEET) OF WASTE SHIPPED TO A COMMERCIAL DISPCSÃ FACIIITI

\section{CUBIC FEET SHIPPED}

ACTUAL SHIPPED IN 1978

ACTURL SHIPPED IN 1979

ACTUAL SHIPPED IN 1980

INDICSTE TOTAL YEARIY VOLUNE (IN CUBIC FEET) OF WASTE PROJECTED TO BE GEISERATED WHICH: WIIL BE SHIPPEO.
\end{abstract}

CUBIC FEET ESTIMATED

ESTIMATED GENERATION IN 1981
ESTIMATED GENERATION IN 1985
ESTINIATED GENERATION IN 1990

INDICATE THE QUANTITY OE RADIOACTIVITY (IN CURIES) SHIPPED TO A COMMERCIAL FACIEITY IN THE YEARS 1979, 1979 AND 1980.

\begin{tabular}{|l|l|l|l|}
\hline \multirow{2}{*}{ ISOTCRE } & \multicolumn{3}{l}{ QUANITIES SHIPPED (CURIES): } \\
\cline { 2 - 4 } & 1978 & 1979 & 1980 \\
\hline & & & \\
\hline & & & \\
\hline & & & \\
\hline & & & \\
\hline & & & \\
\hline & & & \\
\hline & & & \\
\hline & & & \\
\hline & & & \\
\hline
\end{tabular}




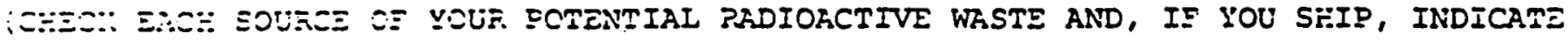
Z:

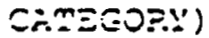

SOURCE OE RADIOACTIVITY

() NUELEAR REACTOR

( ) NECTRON GENERATOR

( ) CICLCTRON OR SYNCHROTRON

( ) SEALED SOURCE

( ) UNSELTED RBDIOACTIVE MATERIIL

( ) NAEUNRE ORES OR MIIL TAILINGS

i) OTYES (EPECIEY)
PERCENT OF WASTE VOLUME SYIPPED

IF YOU LS NOT SHID EADIOACTIVE WASTES, YOU HAVE CCMPLETED THE QUESTIOMNAIRE. THAMK YOU. IE YOU DO S:IP, PLERSE CONTINUE WITR THE FOLIOWING QUESTIONS.

EART IV - PHYSICAI EORM OE SHIPPED WASTES

¿C̈:ECK EACH FORH OE WASTE WAICH YOU SAIP AND INDICATE THE PERCENTAGE OF YOUR TOTAL S:̈-PPED hASTE VOLUME REPRESENTING EACH. FORM)

\section{$100 \%$}

PERCENT OF WASTE VOLUME SHIPPED

( ) DRE SOIIDS, TRASH, IRRADISTED COMPONENTS

( ) SCIIDIFIED OR ABSORBED IIQUIDS, SOIID SIUDGES, SPENT RESINS, FIITER SLUDGES OR EVARORF.TOR BOTTOMS

( ) ANIMAL CARCASSES OR OTHER BIOLOGICAL WASTE

!) SEIEED SOURCES

( ) OTYER (SDECIEY)

DOES NASTE CONTAIV ANY MATERIAL WRICH IS POTENTIALIY:
포 Nㅗ
( ) ( ) COMSUSTIBLE
( ; ( ) EXPLOSIVE
( ) ( ) CHEMICATIY TOXIC

WHAZ SEZPENNG CONTAENERS DC YOU USE?
( ) 55 GALION STEEI DRLMS
( ) 30 GALION STEEL DRUMS
( ) OTHER (SPECIFY) 
VI:Z ON-SITE PROCESSENG OF WASTE DO YOU EMPLOY'

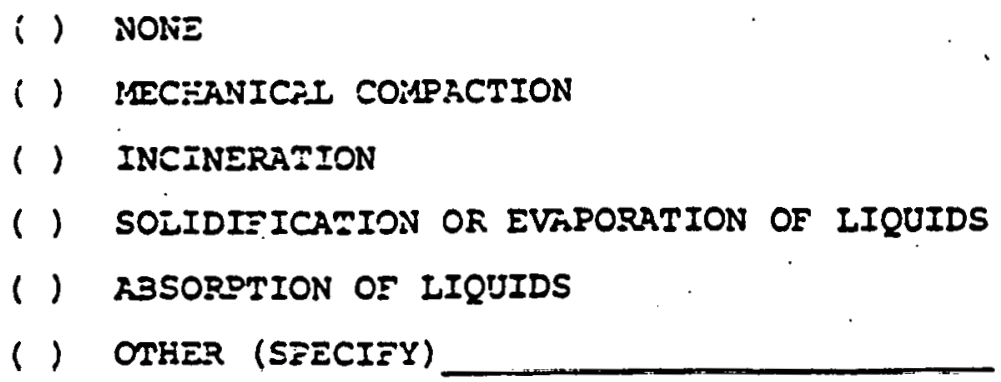

FART V - WASTE QUANTITY

INDICATE TOTAL YEARIY VOLOUE (IN CUBIC FEET) OF WASTE SHIPPED TO A COMAERCIAL DESPCSAL EACIIITI CUBIC EEET SEIPPED

ACTUAL SHIPPED IN 1978

ACTUAL SHIPPED IN 2979

ACTUAL SHIPPED IN 1980

INDICETE TOTAL YEARIY VOLUNE (IN CUBIC FEET) OF WASTE PROIECTED TO BE GEITERATED WHIC:: WIII BE SHIPPED.

\section{CUBIC FEET ESTIMATED}

ESTIMATED GENERATION IN 1981

ESTIMATED GENERATION IN 1985

ESTIMLTED GENERATION IN 1990

INDICATE THE QUANTITY OE RADIOACTIVITY (IN CURIES) SHIPPED TO A COMMERCIAL FAEIEITY IN THE YEARS 1979, 1979 AND 1980.

\begin{tabular}{|c|c|c|c|}
\hline \multirow[b]{2}{*}{ ISOTCPE } & \multicolumn{3}{|c|}{ QUANTITIES SHIPPID (CURIES) } \\
\hline & 1978 & 1970 & 1980 \\
\hline & & & \\
\hline & & & \\
\hline & & & \\
\hline & & & \\
\hline & & & \\
\hline & & & \\
\hline & & & \\
\hline & & & \\
\hline & & & \\
\hline & & & \\
\hline
\end{tabular}


THIS PAGE

\section{WAS INTENTIONALLY \\ LEFT BLANK}




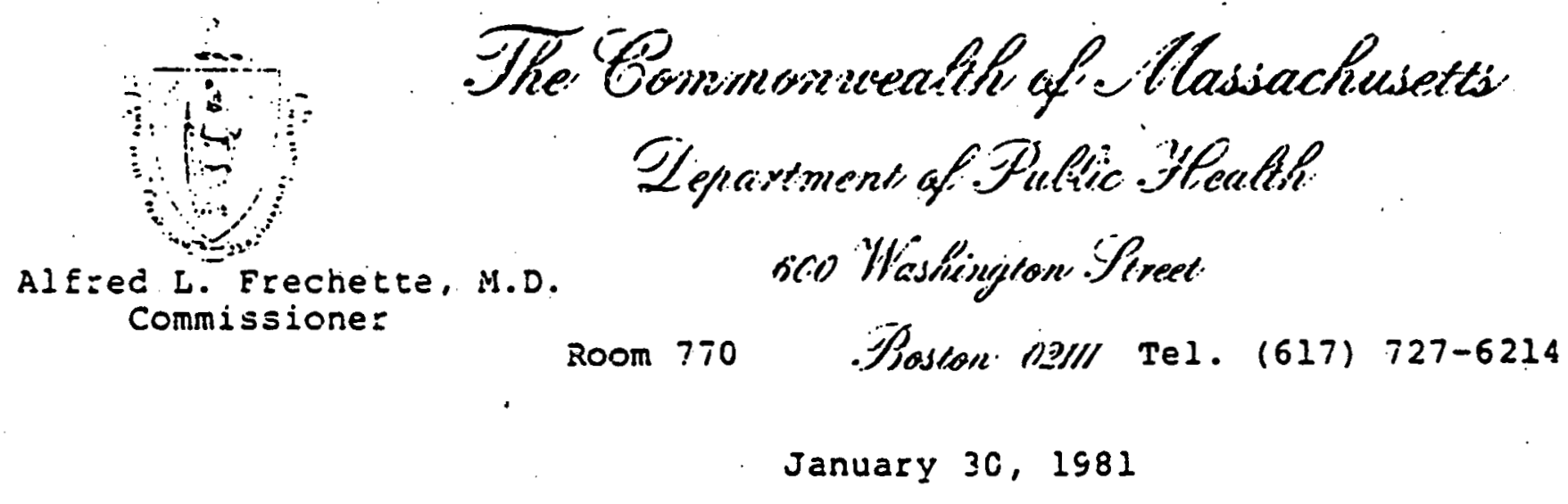

mo: All Racioactive Material License Holders in Massachusetts

SIIBJECT: Survey of Low-revel Radioacti:a Waste Disposal Practices

Dear Sir:

Continued free access to proper low-level radioactive waste disposal sites is an important priority for users of racioactive material within Massachusetts. The Politesh Corporation is conducting a survey of nuclear material licensees for the $U$. S. Department of Energy to ascertain the volume and nature of waste generated in Massachusetts. The results of this survey will form an important part of the planning and future decisions regarding waste disposal site access.

This office encourages you to respond in timely fashion to che questionnaire contained in the accompanying materials. The quality of planning for radioactive waste disposal is dependent upon accurate data on the current waste situation.

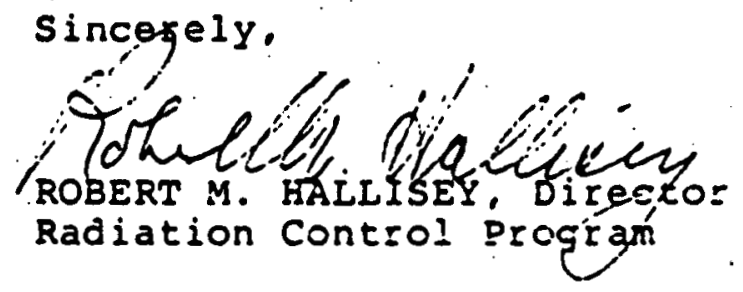

RMY: : 11 
Dear Sirs:

The enclosed Radioactive Waste Survey is one part of a project by POIITECH to assist the U.S. Department of Energy in the Development of a National Low-level Waste Management Program. Compilation of accurate and current information about low-level waste generation, treatment, storage, shipments, and disposal is essential to implement this progrem. It is towards this end that POLITECH seeks your cooperation in completing this survey form. The enclosed Radioactive Waste Survey is largely self-explanatory, and the following instructions provide general guidelines. If you have any specific questions or concerns, please call either Chris Eakle at (512) 478-2126 or Revin Dinan at (202) 659-0106.

\section{GENERAL INSTRUCTIONS}

1. If possible, all quantitative data should be taken directly from shipment records. If this is not possible, please estimate answers as accurately as possible.

2. Please explain or specify answers (where requested) as completely as possible. If additional space is needed, please use the space on the last page of this questionnaire.

3. When you have completed this questionnaire, please return it in the enclosed stamped, self-addressed envelope.

4. For any radioactive wastes not shipped to a licensed storage or disposal facility (e.g., wastes contaminated with isotopes which decay to background levels, or wastes aisposed in trash), please Eill out the survey form with the amount of material received each year and where those radioactive materials were disposed.

Thank you very much for your cooperation.

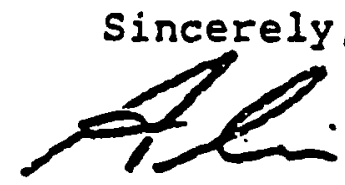

Alvin C. Askew

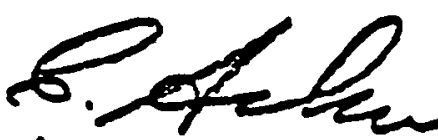

President 


\section{MASSACHUSETTS RADIOACTIVE WASTE SURVEY}

\section{Use of Commercial Low-Level Waste Disposal Facilities}

In the State of Massachusetts, a total of 365 potential shippers of low-level radioactive waste were identified. These potent1al shippers were sent, by direct mail, questionnaires concerning their waste management practices. The respondent was identified as either a medical, educational, industrial, power reactor, or governmental type facility. The tables below present the number of respondents using various disposal methods and the source of radioactivity used at facilities. Table 1 indicates that $47 \%$ ( 77 facilities) of the respondents use commercial low-level waste facilities. The following subsections present a summary of the characteristics and quantity of wastes disposed of by these 77 facilities.

\section{Response to Survey}

Table 1 presents, by facility type, the number of potential shippers surveyed, and the total number and percentage of responses obtained. If a facility provided at least the facility type and method of disposal, the answers were considered a response. If no information was obtained, the type of facilitiy was determined by the facility name.

Forty-five $\%$ of all potential shippers identified provided some degree of response. Their response varied between type of facility, with the range belng $25.0 \%$ for educatlonal faclifties and power reactors to $62.5 \%$ for government facilities.

It should be noted that of the 201 potential shippers (out of 365) which did not provide any information, many may in fact be shippers. It was assumed they in fact do ship wastes, since the only response 
and effort required, if they do not ship wastes, was to return the form. Thus, there is a high probability that the percent response to the survey from shippers may be closer to 27.7\% (77 shipper respondents out of a total of 278 shippers or non-respondents) rather than the $45 \%$ response from all potential shippers.

\section{Origin and Distribution of Shipped Waste}

Table 2 presents the distribution of numbers of facilities shipping wastes by major type of facility and by subgroup within each major type. The origin of radioactivity resulting in shipped waste was grouped into four categorles: nuclear reactor operation, purchased as sealed sources, purchased as unsealed radioactivity, and produced in a cyclotron. Table 3 presents the distribution of number of facilities shipping wastes according to type of facility and origin of radioactivity. It should be noted that more than one origin may be appropriate for a given facility. Approximately 57\% of the facillties shipping wastes obtain the radioactivity as unsealed radioactive material.

\section{Volume of Shipped Waste}

Volumes of low-level wastes shipped to commercial disposal facilities were provided by the 77 respondents that indicated they shipped wastes. Table 4 presents volumes of shipped wastes for the years 1978, 1979, and 1980 for each type of facillty and for subgroups of each facility type.

Table 5 shows the volumes of wastes projected by the respondents to be shipped in the years 1981, 1985, and 1990. If a respondent only provided a projection for 1981 (or 1981 and 1985), the furthest projection in time given was assumed to apply for all subsequent time periods. The data shows an increase in total waste to be shipped of approximately $17 \%$ over the 10-year period of 1981 to 1990. 


\section{Activity of Shipped Waste}

Table 6 presents quantity of activity in the waste shipped for the years 1978, 1979, and 1980 for each type of facility. Table 7 presents. the distribution of activity by shipped radionuclide (by type of facility).

\section{Physical Characteristics of Shipped waste}

On-site processing of low-level waste may be performed to either reduce the volume of the waste (compaction, incineration) or to remove free liquid (solidification, evaporation, absorption). Table 8 shows the number of facilities using these methods. Thirty of the 77 respondents indicated they did not engage in on-site processing of shipped waste. Table 9 presents the type of shipping container used onsite to package waste for transport to disposal facilities. Twentytwo \% of the facilities (shown under "other" column) use cardboard boxes for small volumes of waste which are packaged in drums by the transporter. Shipped waste was categorized as either dry, molst, biological, sealed, or other. Table 10 presents the number of facilities shipping waste in any of these categories. Table 11 indicates the number of facilities shipping wastes with potential nonradiological hazardous characteristics classified as combustible, explosive and/or toxic. 
MASSACHUSETTS RADIOACTIVE WASTE SURVEY

SUMMARY TABLES

$6-4$ 
TABLE 1

RESPONSE TO DIRECT MAIL SURVEY

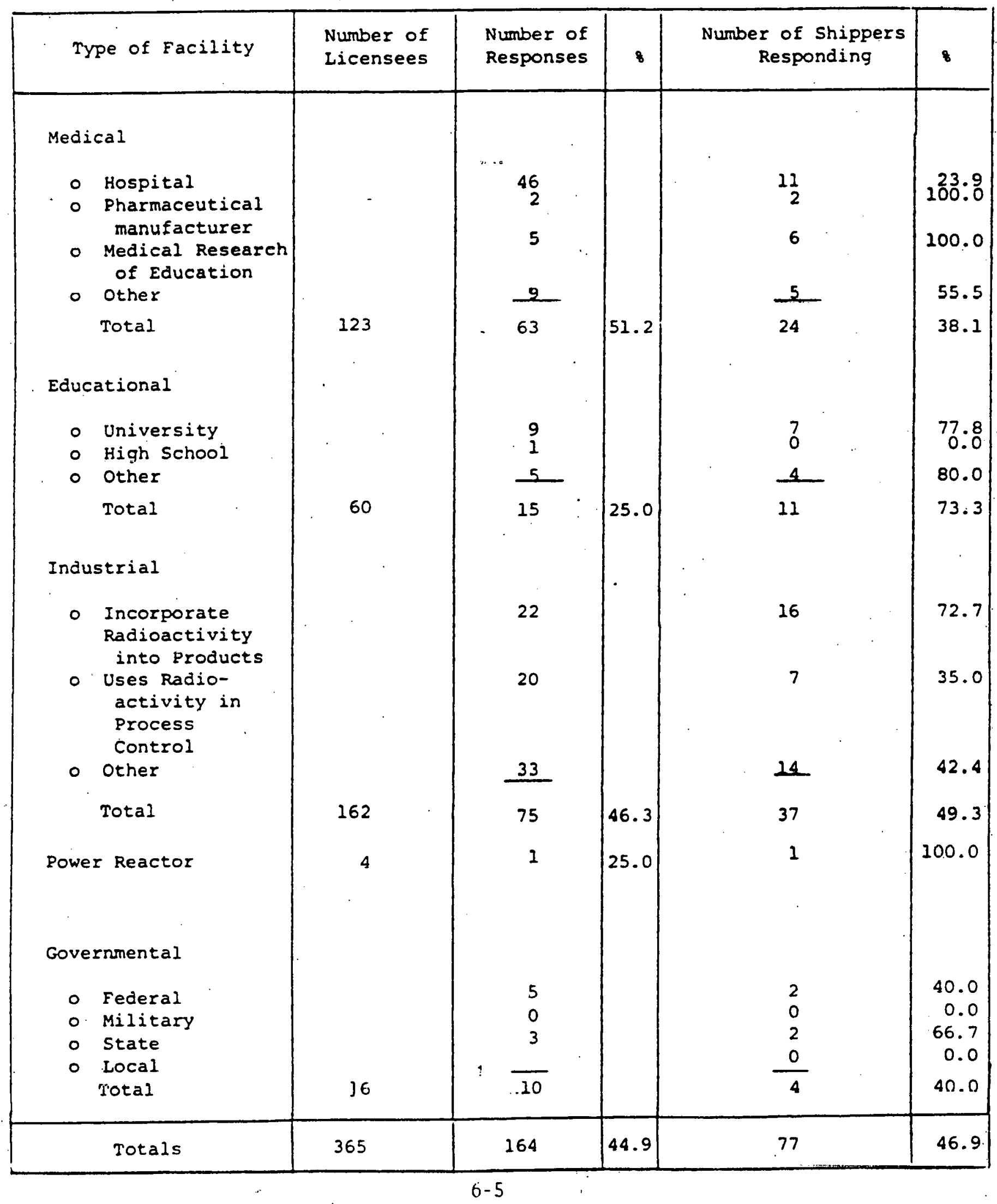


TABLE 2

TYPE OF FACILITIES SHIPPING LOW-LEVEL WASTE

\begin{tabular}{|c|c|c|c|c|}
\hline \multicolumn{2}{|c|}{ Type of Facility } & \multirow{2}{*}{$\begin{array}{l}\text { Number } \\
\text { of facili- } \\
\text { ties } \\
\text { shipping }\end{array}$} & \multirow{2}{*}{$\begin{array}{l}\text { Percent } \\
\text { of all } \\
\text { shippers }\end{array}$} & \multirow{2}{*}{$\begin{array}{l}\text { Percent } \\
\text { of all } \\
\text { respon- } \\
\text { dents }\end{array}$} \\
\hline Facility & subgroup & & & \\
\hline Medical & $\begin{array}{l}\text { Hospital } \\
\text { Pharmaceutical } \\
\text { Research/Education } \\
\text { Other } \\
\text { Total }\end{array}$ & $\begin{array}{r}11 \\
2 \\
6 \\
5 \\
24\end{array}$ & $\begin{array}{r}14.3 \\
2.6 \\
7.8 \\
6.5 \\
31.2\end{array}$ & $\begin{array}{r}6.7 \\
1.2 \\
3.7 \\
3.0 \\
14.6\end{array}$ \\
\hline Education & $\begin{array}{l}\text { University } \\
\text { High School } \\
\text { Other } \\
\text { Total }\end{array}$ & $\begin{array}{r}7 \\
0 \\
4 \\
11\end{array}$ & $\begin{array}{r}9.1 \\
0 \\
5.2 \\
14.3\end{array}$ & $\begin{array}{r}4.3 \\
0 \\
2.4 \\
6.7\end{array}$ \\
\hline Industrial & $\begin{array}{l}\text { Product Use } \\
\text { Process Coritrol } \\
\text { Other } \\
\text { Total }\end{array}$ & $\begin{array}{r}16 \\
7 \\
14 \\
37\end{array}$ & $\begin{array}{r}20.8 \\
9.1 \\
18.2 \\
48.1\end{array}$ & $\begin{array}{r}9.8 \\
4.3 \\
8.5 \\
22.6\end{array}$ \\
\hline Power Reactor & Total & 1 & 1.3 & 0.6 \\
\hline Governmental & $\begin{array}{l}\text { Federal } \\
\text { Military } \\
\text { State } \\
\text { Local } \\
\text { Total }\end{array}$ & $\begin{array}{l}2 \\
0 \\
2 \\
0 \\
4\end{array}$ & $\begin{array}{r}2.6 \\
0 \\
2.6 \\
0 \\
5.2\end{array}$ & $\begin{array}{r}1.2 \\
0 \\
1.2 \\
0 \\
2.4\end{array}$ \\
\hline TOTAL & & 77 & 100.00 & 46.9 \\
\hline
\end{tabular}


TABLE 3

ORIGEN OF RADIOACTIVITY RESULTING IN SHIPPED WASTES

\begin{tabular}{|c|c|c|c|c|c|c|c|c|c|}
\hline \multirow[b]{2}{*}{$\begin{array}{c}\text { Type } \\
\text { of } \\
\text { Eacility }\end{array}$} & \multirow[b]{2}{*}{$\begin{array}{l}\text { Numbe }= \\
\text { of } \\
\text { respon- } \\
\text { dents }\end{array}$} & \multicolumn{2}{|c|}{$\begin{array}{l}\text { Nuclear } \\
\text { reactor }\end{array}$} & \multicolumn{2}{|c|}{ Cyclotron } & \multicolumn{2}{|c|}{$\begin{array}{l}\text { Sealed } \\
\text { sources }\end{array}$} & \multicolumn{2}{|c|}{$\begin{array}{l}\text { Unsealed } \\
\text { radioactive } \\
\text { material }\end{array}$} \\
\hline & & $\begin{array}{c}\text { Number } \\
\text { of } \\
\text { Sources }\end{array}$ & $\left|\begin{array}{l}\text { Percent } \\
\text { of all } \\
\text { shippers }\end{array}\right|$ & $\begin{array}{l}\text { Number } \\
\text { of } \\
\text { sourcest }\end{array}$ & $\begin{array}{l}\text { Percent } \\
\text { of all } \\
\text { shippers }\end{array}$ & $\begin{array}{c}\text { Number } \\
\text { of } \\
\text { sources }\end{array}$ & $\begin{array}{c}\text { Percent } \\
\text { of all } \\
\text { shippers }\end{array}$ & $\begin{array}{c}\text { Number } \\
\text { of } \\
\text { sources }\end{array}$ & $\begin{array}{l}\text { Percent } \\
\text { of al1 } \\
\text { shippers }\end{array}$ \\
\hline Medical . & 24 & 7 & 9.1 & 7 & 9.1 & 8 & 10.4 & 13 & 16.9 \\
\hline Educational & 11 & 1 & 1.3 & 0 & 0.0 & 1 & 1.3 & - 5 & 6.5 \\
\hline Industrial & 37 & 4 & 5.2 & 1 & 1.3 & 12 & 15.6 & 23 & 29.9 \\
\hline Power Reactor & 1 & 0 & 0 & 0 & 0.0 & 0 & 0 & 0 & 0 \\
\hline Governmental & 4 & 0 & 0 & 0 & 0.0 & 1 & 1.3 & 3 & 3.9 \\
\hline TOTAL & 77 & 12 & 15.6 & 8 & 10.4 & 22 & 28.6 & 44 & 57.1 \\
\hline
\end{tabular}

*The total of "number of sources" exceeds the total number of respondents due

to facilities generating waste from several sources. 
VOLUME OF SHIPPED WASTE

Type of Facility

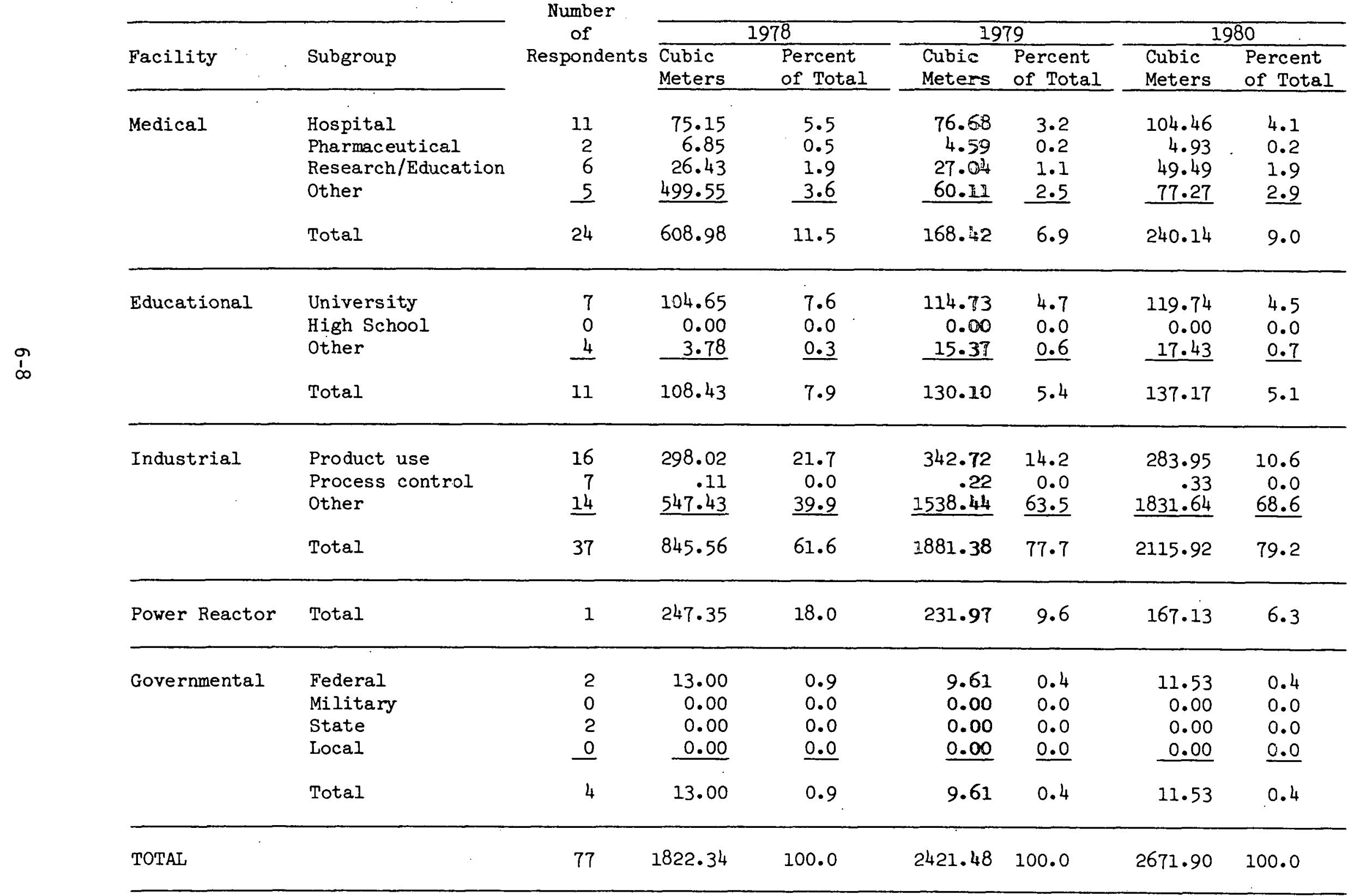

Volume Shipped 
TABLE 5

PROJECTED VOLUMES OF SHIPPED WASTES

\begin{tabular}{|c|c|c|c|c|c|}
\hline \multicolumn{2}{|c|}{ Type of Facility } & \multirow{2}{*}{$\begin{array}{l}\text { Number } \\
\text { of } \\
\text { Respondents }\end{array}$} & \multicolumn{2}{|c|}{ Projected Volume (cubic } & \multirow{2}{*}{$\frac{\text { meters }}{1990}$} \\
\hline Facility & Subgroup & & 1981 & 1985 & \\
\hline \multirow[t]{2}{*}{ Medical } & $\begin{array}{l}\text { Hospital } \\
\text { Pharmaceutical } \\
\text { Research/Education } \\
\text { Other }\end{array}$ & $\begin{array}{r}11 \\
2 \\
6 \\
5 \\
\end{array}$ & $\begin{array}{r}72.29 \\
6.01 \\
64.08 \\
89.60 \\
\end{array}$ & $\begin{array}{r}18.10 \\
6.01 \\
79.52 \\
105.18 \\
\end{array}$ & $\begin{array}{r}18.10 \\
3.17 \\
85.44 \\
183.80 \\
\end{array}$ \\
\hline & Total & 24 & 231.98 & 208.81 & 290.42 \\
\hline \multirow[t]{2}{*}{ Educational } & $\begin{array}{l}\text { University } \\
\text { High School } \\
\text { Other }\end{array}$ & $\begin{array}{l}7 \\
0 \\
4 \\
\end{array}$ & $\begin{array}{r}115.69 \\
0.00 \\
.99 \\
\end{array}$ & $\begin{array}{r}124.84 \\
0.00 \\
54 \\
\end{array}$ & $\begin{array}{r}144.67 \\
0.00 \\
.54 \\
\end{array}$ \\
\hline & Total & 11 & 116.69 & $125 \cdot 38$ & 145.21 \\
\hline \multirow[t]{2}{*}{ Industrial } & $\begin{array}{l}\text { Product use } \\
\text { Process control } \\
\text { Other }\end{array}$ & $\begin{array}{r}16 \\
7 \\
14 \\
\end{array}$ & $\begin{array}{r}318.53 \\
.11 \\
4263.54 \\
\end{array}$ & $\begin{array}{r}345.41 \\
.23 \\
5681.67 \\
\end{array}$ & $\begin{array}{r}402.38 \\
.23 \\
7100.79 \\
\end{array}$ \\
\hline & Total & 37 & 4582.18 & $6027 \cdot 31$ & 7503.40 \\
\hline Power Reactor & Total & 1 & 212.46 & 198.30 & 141.64 \\
\hline \multirow[t]{2}{*}{ Covcrnmental } & $\begin{array}{l}\text { Federal } \\
\text { Military } \\
\text { State } \\
\text { Local }\end{array}$ & $\begin{array}{l}2 \\
0 \\
2 \\
0\end{array}$ & $\begin{array}{r}12.61 \\
0.00 \\
.03 \\
0.00 \\
\end{array}$ & $\begin{array}{r}15.58 \\
0.00 \\
.03 \\
0.00 \\
\end{array}$ & $\begin{array}{r}17.56 \\
0.00 \\
.03 \\
0.00 \\
\end{array}$ \\
\hline & Total & 4 & 12.63 & 15.61 & 17.59 \\
\hline TOTAL & & 77 & 596.29 & 639.21 & 700.31 \\
\hline
\end{tabular}


TABLE 6

ACTIVITY OF SHIPPED WASTE

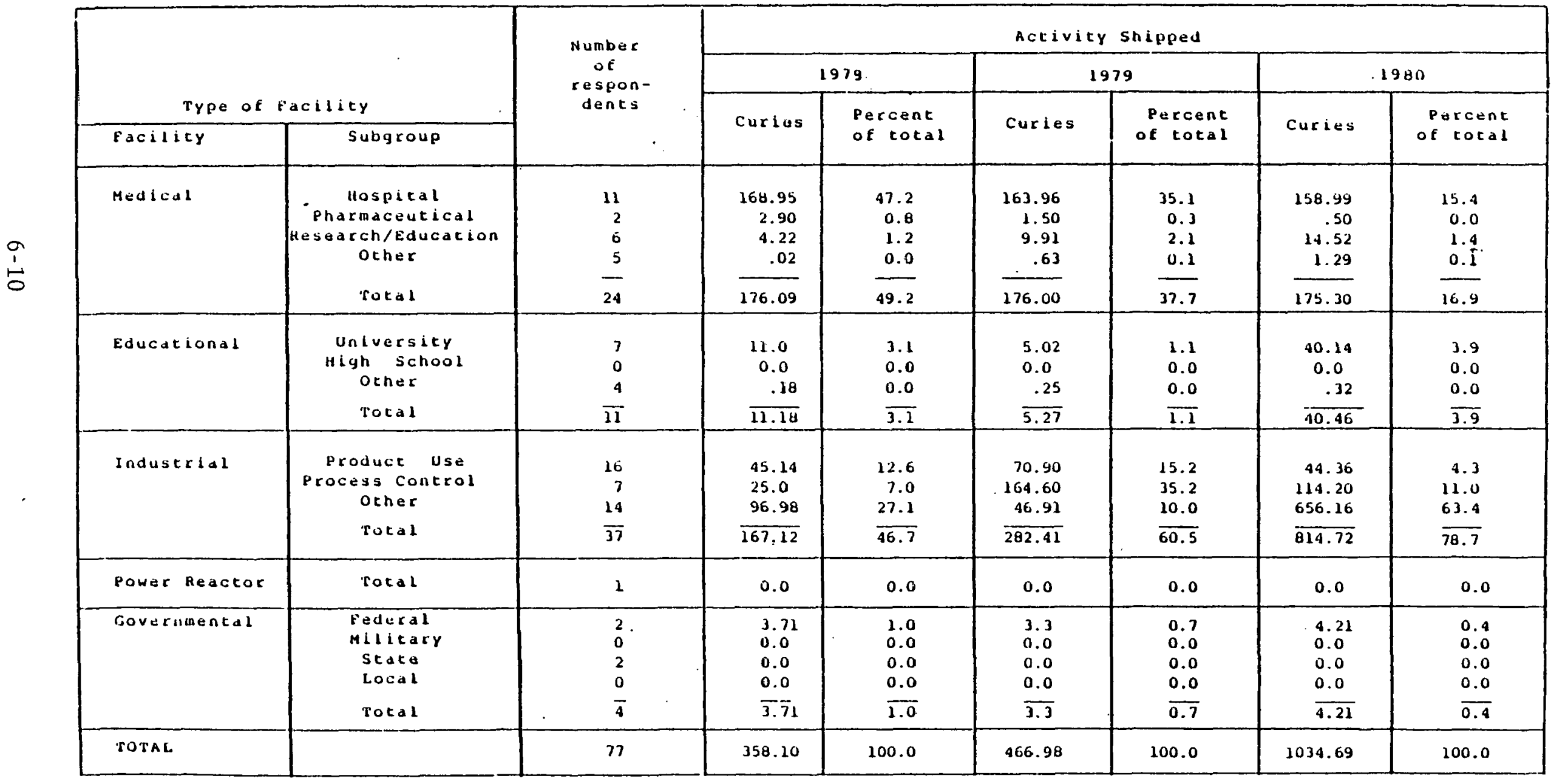


TAELE 7

Massachusetts

RADIONUCLIDES IN SHIPPED WASTES

\begin{tabular}{|c|c|c|c|c|c|c|c|c|c|c|c|c|c|c|c|c|c|c|}
\hline \multirow{3}{*}{ ISOLOPE } & \multicolumn{18}{|c|}{ ACTIVITY (CURIES) } \\
\hline & \multicolumn{3}{|c|}{ l'otal. } & \multicolumn{3}{|c|}{ Medical } & \multicolumn{3}{|c|}{ Educational } & \multicolumn{3}{|c|}{ - Industrial } & \multicolumn{3}{|c|}{ Power Reactors } & \multicolumn{3}{|c|}{ Governioental } \\
\hline & 1978 & 1979 & 1980 & 1978 & 1979 & 1980 & .1978 & 1979 & 1980 & 1978 & 1979 & 1980 & 1978 & 1979 & 1900 & 1978 & 1979 & 1980 \\
\hline$\|-3$ & 48.228 & 50.636 & 10.3864 & 12.035 & 10.02 & 7.1283 & .000001 & .00915 & .04635 & 33.701 & 39.106 & 32.314 & & 0 & & 2.5 & $1 . \overline{5}$ & .90 \\
\hline$c-14$ & 3.20111 & 5.723100 & 6.3885 & 1.0001 & 3.0020 & 4.0015 & .05001 & .231405 & .33103 & 2.212 & 2.480 & 2.056 & & 0 & & 0 & 0 & 0 \\
\hline$p-32$ & .4 & .4336 & .4421 & 0 & 0 & 0 & 0 & .0336 & .0821 & .4 & .4 & .4 & & 0 & & 0 & 0 & $\mathbf{0}$ \\
\hline$p-33$ & 0 & 0 & 0 & 0 & 0 & 0 & 0 & 0 & 0 & 0 & .0 & 0 & & 0 & & 0 & 0 & $0^{\circ}$ \\
\hline$s-35$ & $.505^{\circ}$ & .6625 & .7083 & 0 & 0 & 0 . & 0 & .0272 & .0698 & .505 & .6353 & .6385 & & 0 & & 0 & 0 & 0 \\
\hline$c l-36$ & 520 & .00112 & .00109 & 0 & o & 0 & .025 & .00112 & .00109 & 0 & 0 & 0 & & 0 & & 0 & 0 & 0 \\
\hline$C: 1-38$ & 0 & .0001 & 0 & 0 & 0 & 0 & 0 & .00001 & 0 & 0 & 0 & 0 & & 0 & & 0 & 0 & 0 \\
\hline$c a-45$ & 0 & 005804 & bu9425 & $\mathbf{0}$ & 0 & 0 & 0 & .041404 & .009455 & 0 & 0 & 0 & & $\mathbf{0}$ & & 0 & 0 & 0 \\
\hline Cr -51 & .505 & .77525 & $.069 \mathrm{l}$ & .4500 & .6500 & .7500 & .025 & .01025 & .0043 & .1 & .1 & .09 & & o & & .010 & .015 & .025 \\
\hline Co -57 & .03062 & .03851 & .0734 & .0101 & .0134 & .0384 & 0 & .000005 & 0 & .01052 & .00104 & .01003 & & 0 & & .010 & .015 & .025 \\
\hline$r e-5 y$ & .010 & .0155 & .0264 & $\mathbf{0}$ & .0035 & .0014 & 0 & 0 & 0 & 0 & 0 & 0 & & 0 & & .010 & .015 & .025 \\
\hline co -60 & .72543 & .01809 & 8. 026 & 0 & o & 0 & 0 & 0 & 0 & .71543 & .00309 & 0.0010 & & 0 & & .010 & .015 & .025 \\
\hline $\mathrm{Ni}-63$ & 2061036 & 078514 & 1.1515 & 0 & 0 & 0 & 0 & 0 & 0 & .001836 & 003514 & 1.0015 & & 0 & & .06 & .075 & .150 \\
\hline $2 n-65$ & 0 & .00045 & 0 & 0 & .0002 & 0 & 0 & .00025 & 0 & 0 & 0 & 0 & & u & : & 0 & 0 & 0 \\
\hline $\mathrm{Ca}-67$ & 10.00 & 10.0002 & 10.00 & 10.00 & $1 c .00$ & 10.00 & 0 & $.00(1) 2$ & 0 & 0 & 0 & 0 & & 0 & & 0 & 0 & 0 \\
\hline$s c-75$ & 1.020 & .0150 & .025 & o & 0 & 0 & 0 & 0 & 0 & 1.01 & .0009 & 0 & & 0 & & .010 & .015 & .025 \\
\hline$K r-U S$ & 3.0002 & .00037 & 1000185 & 0 & 0 & 0 & 0 & 0 & 0 & 28.0002 & 192.3 & 114.2 & & 0 & & 0 & 0 & 0 \\
\hline$s r-y 0$ & .010 & All SuOl & .025 & 0 & 0 & 0 & 0 & .000001 & 0 & 0 & 0 & 0 & & $\mathbf{0}$ & & .010 & .015 & .025 \\
\hline Mo - yy & 2.001 & 2.001 & 2.001 & 2.001 & 2.001 & $2.00 L$ & 0 & 0 & 0 & 0 & 0 & 0 & & 0 & & $u$ & 0 & 0 \\
\hline $\mathrm{rc}:-y \cdot 3 \mathrm{ur}$ & 100.0 & 100.0 & 100.0 & 100.0 & 100.0 & 100.0 & 0) & 0 & 0 & 0. & 0 & 0 & & 0 & & 0 & 0 & 0 \\
\hline IOIAL & & sect & bage & Iness & & & & & & & & & & & & & & \\
\hline
\end{tabular}


Massacliusects

TABLE 7 (continued)

RADIONUCIIDES IN SHIPPED WASTES

\begin{tabular}{|c|c|c|c|c|c|c|c|c|c|c|c|c|c|c|c|c|c|c|}
\hline \multirow{3}{*}{ Isotope } & \multicolumn{18}{|c|}{ ACTIVITY (CURIES) } \\
\hline & \multicolumn{3}{|c|}{ Total } & \multicolumn{3}{|c|}{ Medlcal } & \multicolumn{3}{|c|}{ Educactonal } & \multicolumn{3}{|c|}{ Industrial } & \multicolumn{3}{|c|}{ Power Reactors } & \multicolumn{3}{|c|}{ Covernmencal } \\
\hline & 1978 & 1979 & 2980 & 1978 & 1979 & 1900 & 1970 & 1979 & 1980 & 1978 & 1979 & 1980 & 1978 & 1979 & 1980 & 1978 & 1979 & 1980 \\
\hline$R u-103$ & 0 & 202605 & .0008 & 0 & 0 & 0 & 0 & 002605 & .0008 & 0 & $\mathbf{0}$ & 0 & & 0 & & 0 & 0 & 0 \\
\hline $11-111$ & 10.00 & 10.00 & 10.00 & 10.00 & 10.00 & 10.00 & $\mathbf{0}$ & 0 & 0 & 0 & 0 & 0 & & 0 & & 0 & 0 & 0 \\
\hline$I-125$ & 32,4845 & 32.1069 & 34.402 & 28.631 & 28.094 & 28.479 & .025 & 024965 & 098245 & 3.8325 & 3.973 & 5.800 & & 0 & & .010 & .015 & .025 \\
\hline$I-129$ & .002 & .00501 & .005 & .002 & .005 & .005 & $\mathbf{0}$ & 0 & 0 & 0 & .00001 & 0 & & $\mathbf{0}$ & & 0 & 0 & 0 \\
\hline $1-131$ & 10.25125 & 10.500 & 10.754 & 10.251 & 10.500 & 10.750 & 0 & .00025 & 0 & 0 & 0 & 0 & & 0 & & 0 & $\mathbf{0}$ & 0 \\
\hline ba -133 & .0252 & .00025 & 000001 & 0 & 0 & 0 & .025 & .00005 & 0 & .0002 & .0002 & .000001 & & 0 & & 0 & 0 & 0 \\
\hline$c s-134$ & ذ. & .5 & .3 & .5 & .5 & .3 & 0 & 0 & 0 & 0 & 0 & 0 & & 0 & & 0 & 0 & 0 \\
\hline $\operatorname{cs}-13 \%$ & .010295 & .6152701 & 191023 & 0 & 0 & $\mathbf{0}$ & 0 & 0000001 & 0 & 000295 & .60027 & 191.0 & & 0 & & .010 & .015 & .025 \\
\hline $1 v-192$ & 94.31 & 22.25 & 399.15 & .25 & .25 & .25 & 0 & 0 & 0 & 94.13 & 22.00 & 398.9 & . & 0 & & 0 & 0 & 0 \\
\hline$T 1-201$ & 0 & .0001 & 0 & 0 & 0 & 0 & 0 & .0001 & o & 0 & 0 & 0 & & 0 & & 0 & 0 & 0 \\
\hline Po -210 & .00001 & 00001 & pooous & 0 & 0 & 0 & 0 & 0 & 0 & .00001 & .00001 & 10000004 & & 0 & & 0 & 0 & 0 \\
\hline $8 a-226$ & 0 & p000001 & U600s & 0 & 0 & 0 & 0 & 0000001 & 0 & 0 & 0 & .00605 & & 0 & . & 0 & 0 & 0 \\
\hline Mixtures & 10.453 & 164.95 & 62.1 & 1.0 & 1.0 & 1.0 & 0 & 0 & 0 & .1 & .1 & .1 & 9.753 & 163.85 & 61.0 & 0 & 0 & 0 \\
\hline Utepleted) & 3.172 & 24.7737 & 60.0 & & & & & & & 2.1 & $23.701 \%$ & 57.0 & & & & 1.072 & 1.65 & 3.0 \\
\hline U 238 & $.096 i$ & .021 & .019 & .003 & & & & & & .043 & .021 & .019 & & & & & & \\
\hline HM 147 & .00005 & .0251 & 00005 & & & & & & & .00005 & .0251 & .00005 & & & & & & \\
\hline Aun - 241 & & .0005 & & & & & & & & & .0005 & & & & & & & \\
\hline $5 e-5 j$ & & .2 & & & & & & & & & .2 & & & & & & & \\
\hline$c d-109$ & & .006 & & & & & & & & & .006 & & & & & & & \\
\hline $2 i-03$ & 11.0 & 5.0 & 40.0 & & . & & 11.0 & 5.0 & 40.0 & & & & & & & & & \\
\hline TOIAL & $36 \% .14$ & (16) In) & 11\%2.1\% & 176.13 & 170.04 & 174.78 & 1.1 .14 & 5.399 & 410.654 & 165.04 & ¿405.67 & $011.40 \%$ & p9.753 & 16.3 .84 & 61.0 & 4.432 & 3.345 & 4. 25 \\
\hline
\end{tabular}


I'AUIE: U

Mot:aidullusin-t t::

ONSITE PROCESSING OF SHIPPEO WASTE

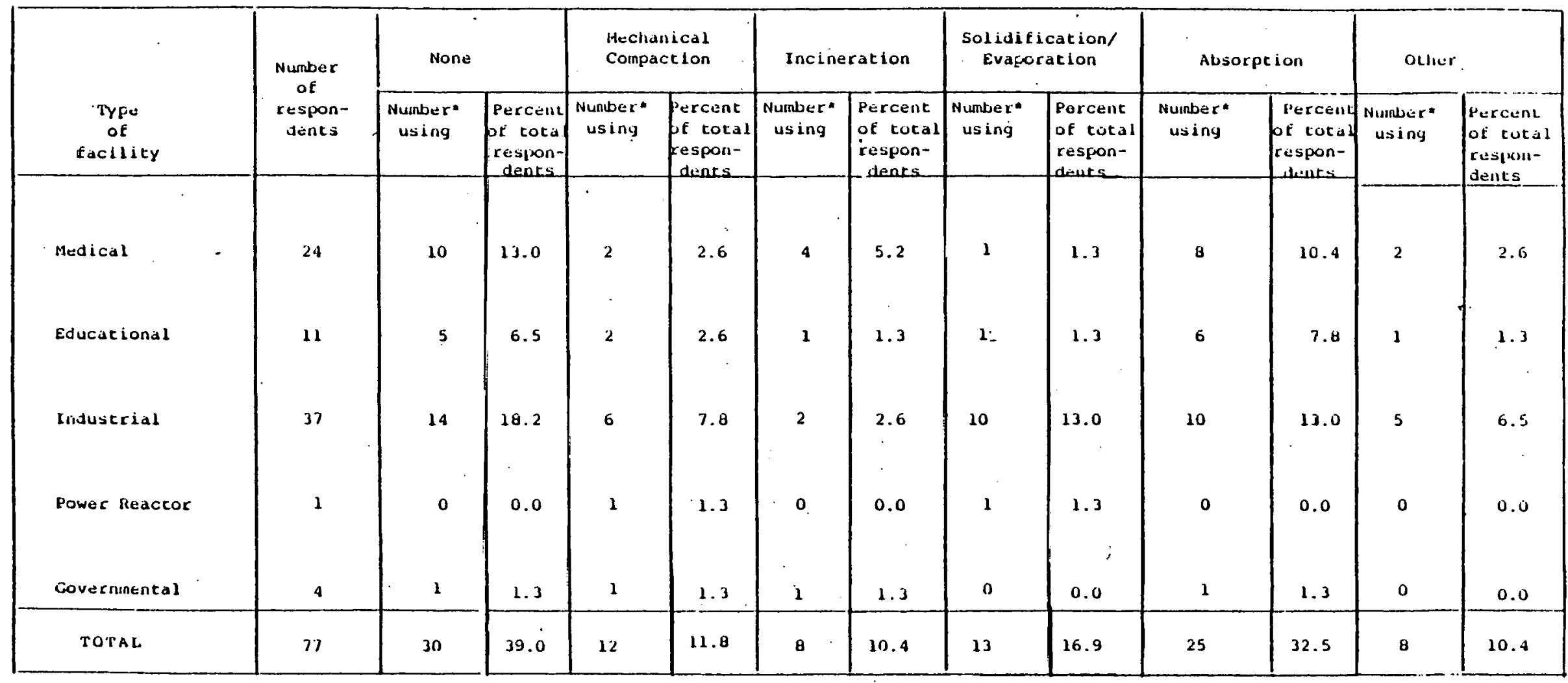

"Whe total of "nunber using" exceeds the total number of respondents due to the use of several practices at each facility. 
TABLE 9

SHIPPING CONTAINER USED

\begin{tabular}{|c|c|c|c|c|c|c|c|}
\hline \multirow[b]{2}{*}{$\begin{array}{c}\text { Type } \\
\text { of } \\
\text { facility }\end{array}$} & \multirow[b]{2}{*}{$\begin{array}{l}\text { Number } \\
\text { of } \\
\text { respon- } \\
\text { dents }\end{array}$} & \multicolumn{2}{|c|}{ 55-gal. drums } & \multicolumn{2}{|c|}{ 30-gal.arums } & \multicolumn{2}{|c|}{ Others } \\
\hline & & $\begin{array}{c}\text { Number } \\
\text { using }\end{array}$ & $\begin{array}{l}\text { Percent } \\
\text { of } \\
\text { total } \\
\text { respon- } \\
\text { dents }\end{array}$ & $\begin{array}{c}\text { Number } \\
\text { using }\end{array}$ & $\begin{array}{l}\text { Percent } \\
\text { of } \\
\text { total } \\
\text { respon- } \\
\text { dents } \\
\end{array}$ & $\begin{array}{c}\text { Number } \\
\text { using }\end{array}$ & $\begin{array}{l}\text { Percent } \\
\text { of } \\
\text { total } \\
\text { respon- } \\
\text { dents }\end{array}$ \\
\hline Medical & 24 & 13 & 16.9 & 12 & 15.6 & 3 & 3.9 \\
\hline Educational & 11 & 9 & 11.7 & 7 & 9.1 & 0 & 0.0 \\
\hline Industrial & 37 & 15 & 19.5 & 18 & 23.4 & 13 & 16.9 \\
\hline Power Reactor & 1 & 1 & 1.3 & 0 & 0.0 & 1 & 1.3 \\
\hline Governmental & 4 & 2 & 2.6 & 2 & 2.6 & 1 & 1.3 \\
\hline TOTAL & 77 & 40 & 51.9 & 39 & 50.6 & 17 & 22.1 \\
\hline
\end{tabular}

*The total of "number using" exceeds the total number of respondents due to several types of containers being used at some facilities. 
TABEF. 10

PIYYSICAL FORM OF SIIIPPEO WASTE

9
1
0

\begin{tabular}{|c|c|c|c|c|c|c|c|c|c|c|c|}
\hline \multirow[b]{2}{*}{$\begin{array}{c}\text { Type } \\
\text { of } \\
\text { facility }\end{array}$} & \multirow{2}{*}{$\begin{array}{l}\text { Number } \\
\text { of } \\
\text { respon-- } \\
\text { dents }\end{array}$} & \multicolumn{2}{|l|}{ Ory } & \multicolumn{2}{|c|}{$\begin{array}{l}\text { Molst/potential } \\
\text { free liquid }\end{array}$} & \multicolumn{2}{|c|}{ Biologlcal Waste } & \multicolumn{2}{|c|}{ Sealed Sources } & \multicolumn{2}{|c|}{ Otloc:r } \\
\hline & & $\begin{array}{l}\text { Number of } \\
\text { facili- } \\
\text { ties }\end{array}$ & $\begin{array}{r}\begin{array}{r}\text { Percent } \\
\text { of tot a } \\
\text { respon- } \\
\text { dents }\end{array} \\
\end{array}$ & $\begin{array}{l}\text { Number } \\
\text { of } \\
\text { facill- } \\
\text { ties } \\
\end{array}$ & $\begin{array}{l}\text { Pexcent } \\
\text { pe total } \\
\text { espon- } \\
\text { dents }\end{array}$ & $\begin{array}{c}\text { Number } \\
\text { of } \\
\text { facill- } \\
\text { ties }\end{array}$ & $\begin{array}{l}\text { Percent } \\
\text { of total } \\
\text { respon- } \\
\text { dents }\end{array}$ & $\begin{array}{l}\text { Number of } \\
\text { facili- } \\
\text { ties }\end{array}$ & $\begin{array}{l}\text { Percent } \\
\text { of total } \\
\text { respon- } \\
\text { dents }\end{array}$ & $\begin{array}{c}\text { Number of } \\
\text { facili- } \\
\text { ties }\end{array}$ & $\begin{array}{l}\text { receont } \\
\text { of toital } \\
\text { respon- } \\
\text { ilcolis }\end{array}$ \\
\hline Medical & 24 & 17 & 22.1 & 11 & 14.3 & 2 & 2.6 & 2 & 2.6 & 9 & 13.7 \\
\hline Educational & 11 & 10 & 13.0 & 8 & 10.4 & 6 & 7.8 & 1 & 1.3. & 3 & 3.9 \\
\hline Industrial & 37 & 24 & $31 . ?$ & 11 & 14.3 & 1 & 1.3 & 11 & 14.3 & $\mathbf{B}$ & 10.1 \\
\hline Power Reactor & 1 & 0 & 0.0 & 0 & 0.0 & 0 & 0.0 & $\mathbf{0}$ & 0.0 & 0 & 0.0 \\
\hline Coverninental & 4 & 2 & 2.6 & 2 & 2.6 & 0 & 0.0 & 1 & 1.3 & 0 & 0.0 \\
\hline TOTAI. & 77 & 53 & 68.8 & 32 & 41.6 & 9 & 1.1 .7 & 15 & 19.5 & 20 & 26.0 \\
\hline
\end{tabular}

"The total of "number of facilities" exceeds the total number of respondents due to waste being in several forms at some facijities. 
TABLE 11

ORIGIN OF RADIOACTIVITY RESULTING IN SHIPPED WASTES

\begin{tabular}{|c|c|c|c|c|c|c|c|}
\hline \multirow{3}{*}{$\begin{array}{c}\text { Type } \\
\text { of } \\
\text { facility }\end{array}$} & \multirow{3}{*}{$\begin{array}{l}\text { Number } \\
\text { of } \\
\text { respon- } \\
\text { dents }\end{array}$} & \multicolumn{6}{|c|}{ Type of Potential Hazard } \\
\hline & & \multicolumn{2}{|c|}{ Combustible } & \multicolumn{2}{|c|}{ Explosive } & \multicolumn{2}{|c|}{ Toxic } \\
\hline & & $\begin{array}{l}\text { Number } \\
\text { of } \\
\text { sources }\end{array}$ & $\begin{array}{l}\text { Percent } \\
\text { of all } \\
\text { shippers }\end{array}$ & $\begin{array}{l}\text { Number } \\
\text { of } \\
\text { sources }\end{array}$ & $\begin{array}{l}\text { Percent } \\
\text { of all } \\
\text { shippers }\end{array}$ & $\begin{array}{c}\text { Number } \\
\text { of } \\
\text { sources }\end{array}$ & $\begin{array}{l}\text { Percent } \\
\text { of all } \\
\text { shippers }\end{array}$ \\
\hline Medical & 24 & 10 & 13.0 & 5 & 6.5 & 9 & 11.7 \\
\hline Educational & $1 i$ & 5 & 6.5 & 1 & 1.3 & 6 & 7.8 \\
\hline Industrial & 37 & 17 & 22.1 & 1 & 1.3 & 12 & 15.6 \\
\hline Power Reactor & 1 & 1 & 1.3 & 0 & 0.0 & 0 & 0.0 \\
\hline Governmental & 4 & 2 & 2.6 & 1 & 1.3 & 2 & 2.6 \\
\hline TOTAL & 77 & 35 & 45.5 & 8 & 10.4 & 29 & 37.7 \\
\hline
\end{tabular}




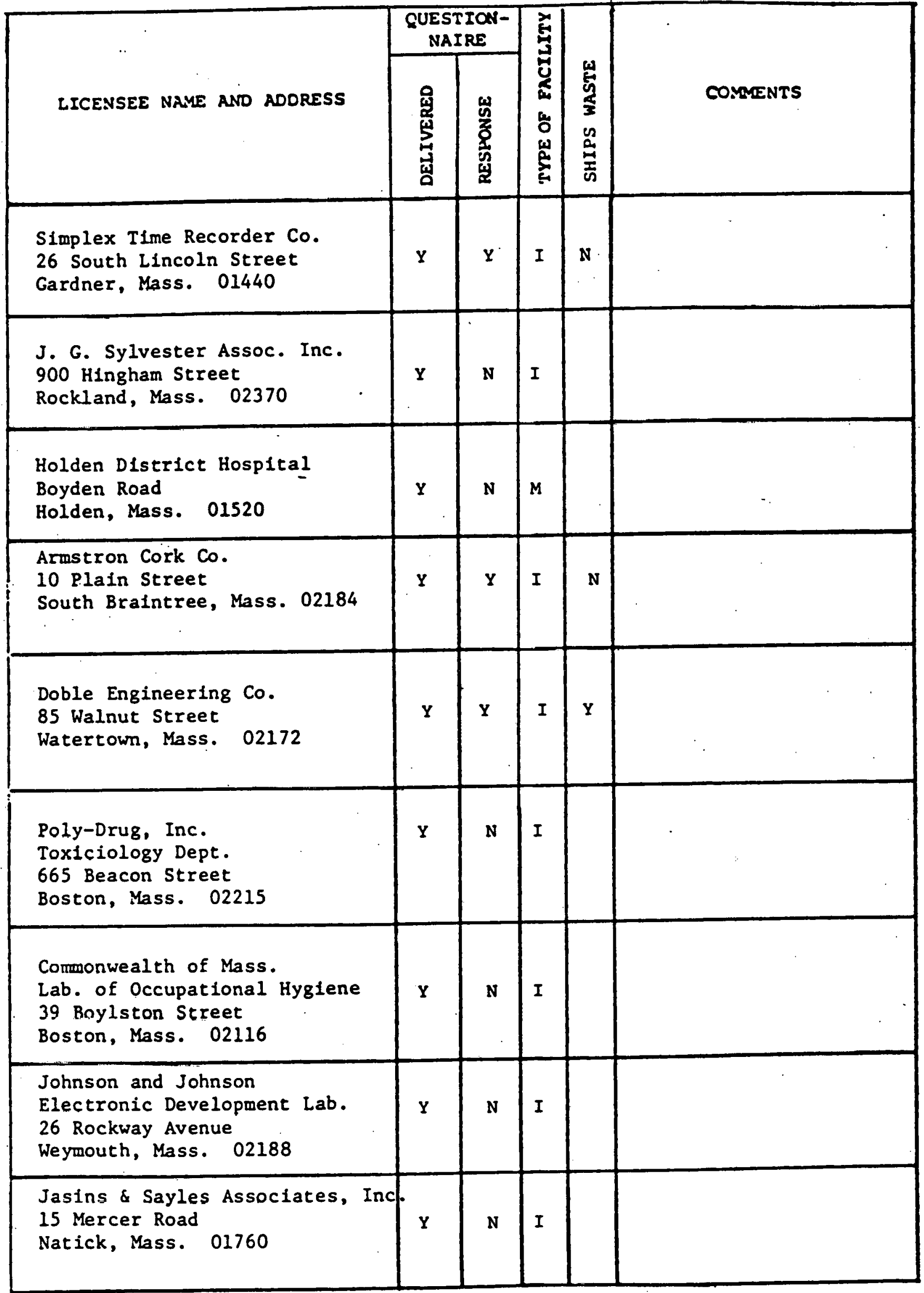




\begin{tabular}{|c|c|c|c|c|c|}
\hline \multirow[b]{2}{*}{ LICENSEE NAME AND ADDRESS } & \multicolumn{2}{|c|}{$\begin{array}{l}\text { QUESTION- } \\
\text { NAIRE }\end{array}$} & \multirow{2}{*}{ 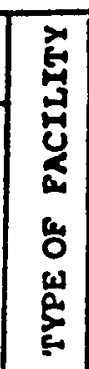 } & \multirow[b]{2}{*}{ 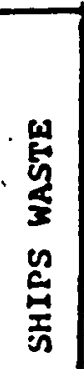 } & \multirow[b]{2}{*}{ COMENTS } \\
\hline & 迹 & 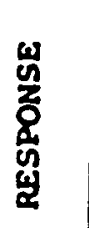 & & & \\
\hline $\begin{array}{l}\text { New England Biolabs } \\
283 \text { Cabot Street } \\
\text { Beverly, Mass. } 01915\end{array}$ & $Y$ & $\mathrm{~N}$ & M & & \\
\hline $\begin{array}{l}\text { Hale Hospital } \\
40 \text { Buttonwood Ave. } \\
\text { Haverh11, Mass. } 01830\end{array}$ & $Y$ & $\mathrm{~N}$ & $M$ & & \\
\hline $\begin{array}{l}\text { Emmanuel College } \\
\text { Physics Research Div. } \\
400 \text { the Renway } \\
\text { Boston, Mass. } 02115\end{array}$ & $Y$ & $\mathbf{Y}$ & $E$ & No & \\
\hline $\begin{array}{l}\text { Harrington Memorial Hospital } \\
100 \text { South Street } \\
\text { Southbridge, Mass. } 01550\end{array}$ & $\mathbf{Y}$ & $\mathbf{Y}$ & $M$ & $\mathbf{N}$ & \\
\hline $\begin{array}{l}\text { Bóks School } \\
\text { North Andover, Mass. } 01845\end{array}$ & $\mathbf{Y}$ & $\mathbf{Y}$ & $\varepsilon$ & $\mathbf{N}$ & \\
\hline $\begin{array}{l}\text { ECO - Control } \\
56 \text { Rogers Street } \\
\text { Cambridge, Mass. } 02142\end{array}$ & $\mathbf{Y}$ & $\mathbf{N}$ & I & & \\
\hline $\begin{array}{l}\text { Comonwealth of Mass. } \\
\text { Dept. of Natural Resources Cat } \\
\text { Cove Marine Lab. } \\
92 \text { Fort Ave. } \\
\text { Salem, Mass. } 01970\end{array}$ & $\mathbf{Y}$ & $\mathbf{x}$ & $G$ & $\mathbf{N}$ & \\
\hline $\begin{array}{l}\text { EG\&G Bionomics, Inc. } \\
\text { Main Street } \\
\text { Wareham, Mass. } 02571\end{array}$ & $\mathbf{Y}$ & $\mathbf{Y}$ & I & $\mathbf{Y}$ & \\
\hline $\begin{array}{l}\text { Haller Testing Lab. of Mass. Inc } \\
\text { 11A Walkup Drive } \\
\text { Westborough, Mass. } 01581\end{array}$ & $Y$ & $\mathbf{N}$ & $I$ & & \\
\hline
\end{tabular}




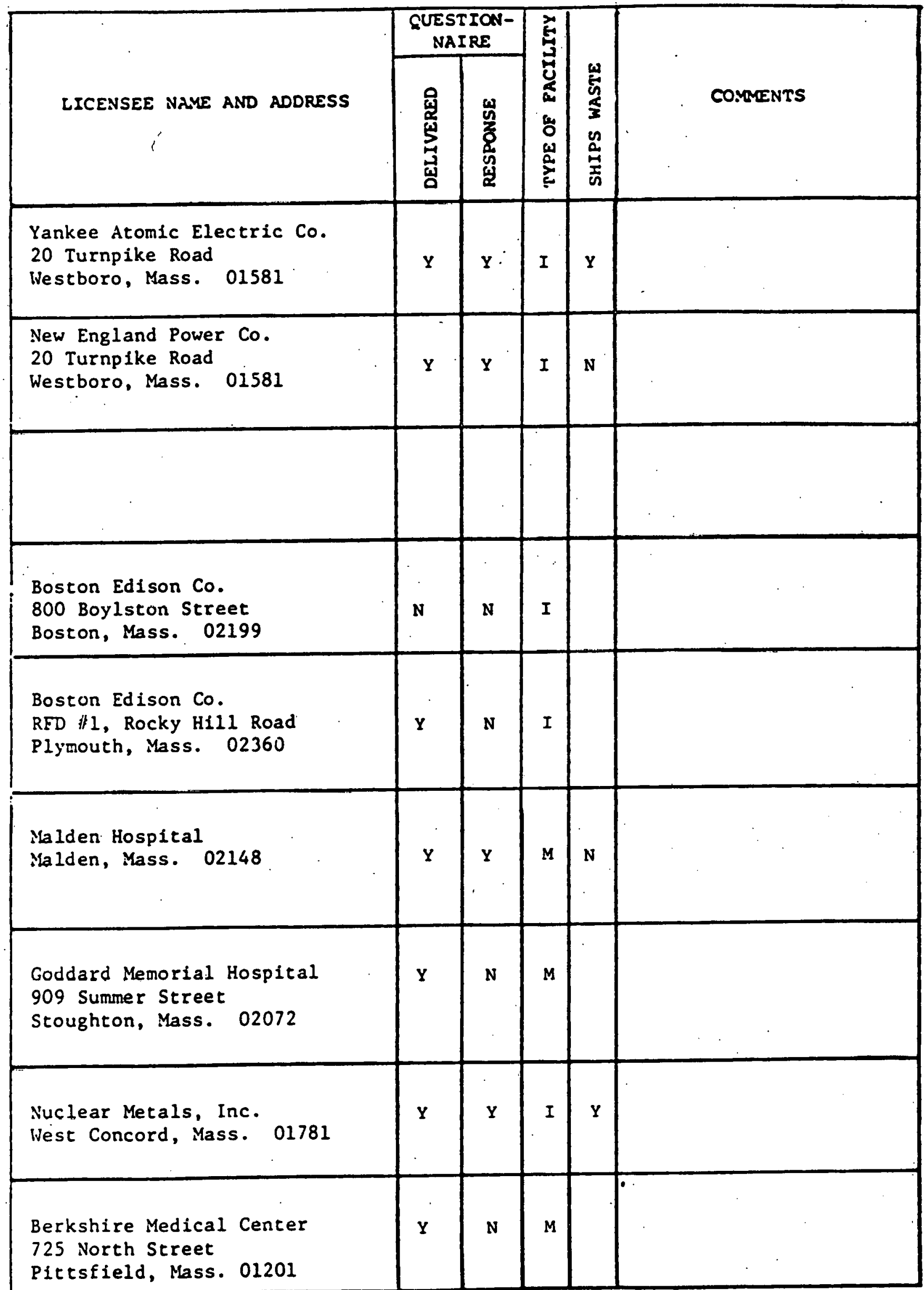




\begin{tabular}{|c|c|c|c|c|c|}
\hline . & $\begin{array}{r}\text { CUES } \\
\text { VA }\end{array}$ & $\begin{array}{l}\text { ICAN- } \\
\text { RE }\end{array}$ & $\vec{G}$ & & \\
\hline LICENSEE NAYE ANO ADORESS & 离 & 筩 & $\begin{array}{l}2 \\
2 \\
0 \\
0 \\
\frac{2}{2} \\
c\end{array}$ & 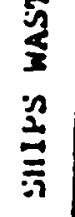 & CC.MENTS \\
\hline $\begin{array}{l}\text { Department of the Army } \\
\text { US Army Materials \& Mech. } \\
\text { Research Agency . } \\
\text { Watertown Arsenal } 02172 \\
\text { Hatertown, Mass. }\end{array}$ & $\mathbf{Y}$ & $\mathbf{N}$ & $\mathbf{G}$ & & \\
\hline $\begin{array}{l}\text { Arnold Greene Testing Labs. } \\
6 \text { Huron Drive } \\
\text { East Natick Ind } \\
\text { Natick, Mass. } 01760\end{array}$ & $\mathbf{Y}$ & $\mathbf{N}$ & I & & \\
\hline $\begin{array}{l}\text { Dennison Manufacturing Co. } \\
300 \text { Howard Street } \\
\text { Framingham, Mass. } 01701\end{array}$ & $\mathbf{Y}$ & $\mathbf{N}$ & $I$ & & \\
\hline $\begin{array}{l}\text { Raytheon Company } \\
\text { Equipment Division } \\
528 \text { Boston Post Road } \\
\text { Sudbury, Mass. } 01776\end{array}$ & $Y$ & $\mathbf{Y}$ & I & $\mathbf{Y}$ & \\
\hline $\begin{array}{l}\text { Mass. Eye E Ear Infirmary } \\
\text { Howe Lab. of Ophehalmology } \\
243 \text { Charies Street } \\
\text { Boston, Mass. } 02114\end{array}$ & $\mathbf{Y}$ & $\mathbf{N}$ & $\mathbf{M}$ & & \\
\hline $\begin{array}{l}\text { Worcester Fdn. for Experi- } \\
\text { mental Biol. Inc. } \\
222 \text { Maple Avenue } \\
\text { Shrewsbury, Mass. } 01545\end{array}$ & $\mathbf{Y}$ & $\mathbf{N}$ & I & & · \\
\hline $\begin{array}{l}\text { Mass. Civil Defense Agency } \\
400 \text { Worcester Road } \\
\text { Framington, Mass. } 01701\end{array}$ & $\mathbf{Y}$ & $\mathbf{N}$ & G & & \\
\hline $\begin{array}{l}\text { St. Elizabeth's Hospital } \\
736 \text { Cambridge Street } \\
\text { Brighton, Mass. } 02135\end{array}$ & $\boldsymbol{Y}$ & $\mathbf{N}$ & $M$ & & \\
\hline $\begin{array}{l}\text { Boston College } \\
\text { Chestnut Hill } \\
\text { Massachusetts } 02167\end{array}$ & $Y$ & $\mathbf{N}$ & $\mathbf{E}$ & & \\
\hline
\end{tabular}




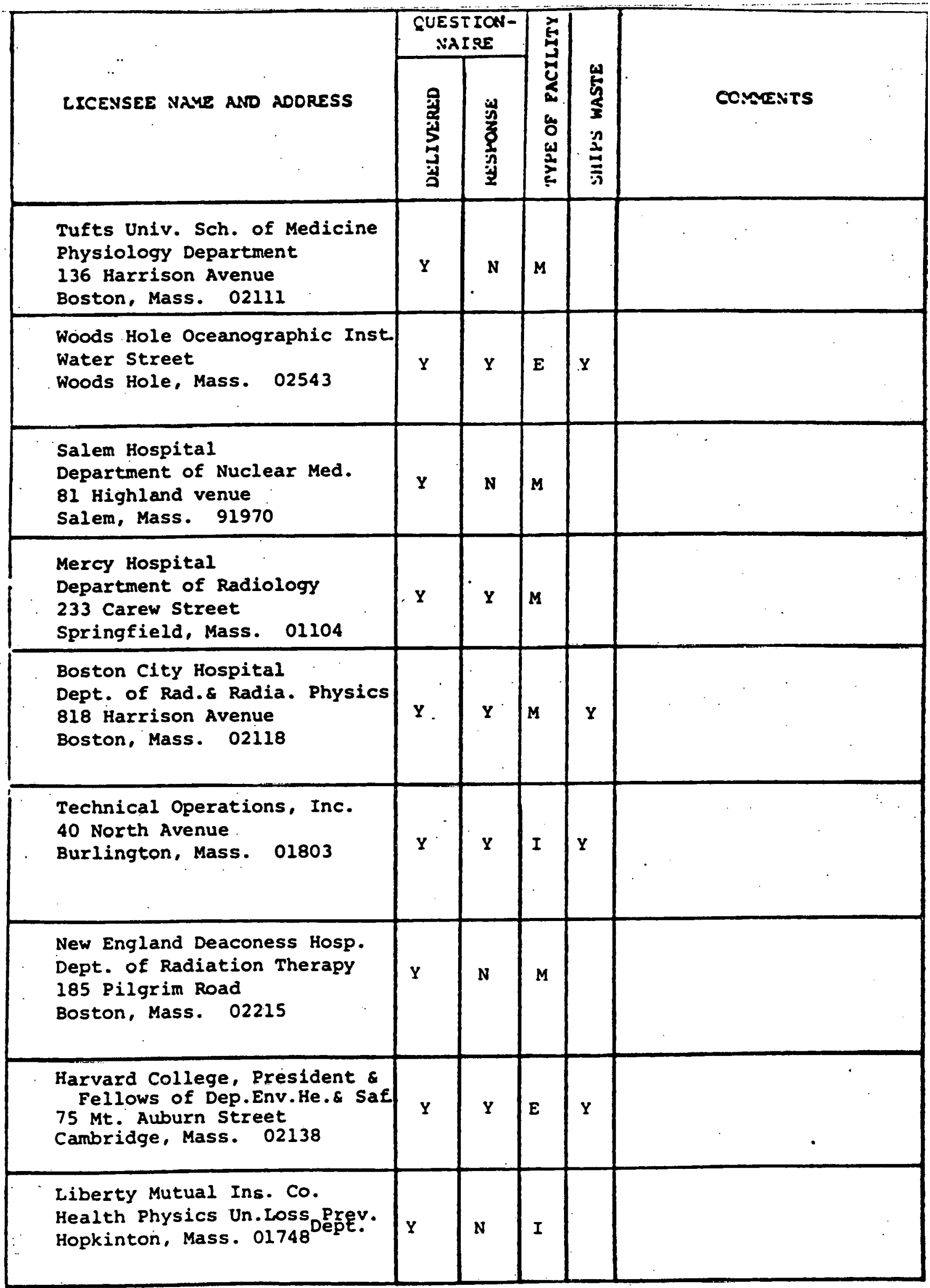




\begin{tabular}{|c|c|c|c|c|c|}
\hline \multirow{2}{*}{ LICENSEE NAME AND ADDRESS } & \multicolumn{2}{|c|}{$\begin{array}{c}\text { QUEST ION- } \\
\text { NAIRE } \\
\end{array}$} & \multirow{2}{*}{ 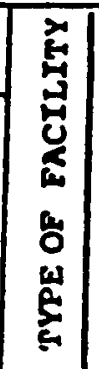 } & \multirow[b]{2}{*}{ 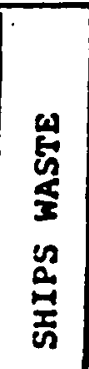 } & \multirow{2}{*}{ COMEnTS } \\
\hline & 鵕 & 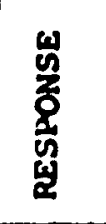 & & & \\
\hline $\begin{array}{l}\text { Myerson Tooth Corporation } \\
66-90 \text { Hamilton Street } \\
\text { Cambridge, Mass. } 02139\end{array}$ & $\mathbf{Y}$ & $\mathbf{Y}$ & I & $\mathbf{Y}$ & \\
\hline $\begin{array}{l}\text { Hardric Laboratories, Inc. } \\
1490 \text { Main Street } \\
\text { Waltham, Mass. } 02154\end{array}$ & $\mathbf{Y}$ & $\mathbf{N}$ & $I$ & & \\
\hline $\begin{array}{l}\text { Wire \& Metal Separation Systems } \\
\text { Inc. } \\
542 \text { Southbridge Street } \\
\text { Worcester, Mass. } 01610\end{array}$ & $\mathbf{Y}$ & $\mathbf{N}$ & $I$ & & \\
\hline $\begin{array}{l}\text { Worc. Dept. of Public Health } \\
419 \text { Belmont Street } \\
\text { Worcester, Mass. } 01604\end{array}$ & $\mathbf{Y}$ & $y$ & G & $\mathbf{N}$ & \\
\hline $\begin{array}{l}\text { Mass. Dept. of Public Works } \\
\text { Research \& Materials Division } \\
99 \text { Worcester Street } \\
\text { Wellesley Hills, Mass. } 02181\end{array}$ & $\mathbf{Y}$ & $\mathbf{Y}$ & G & $\mathrm{N}$ & \\
\hline $\begin{array}{l}\text { Technical Operations, Inc. } \\
\text { Radiation Products Div. } \\
\text { Northwest Industrial Park } \\
\text { Burlington, Mass. } 01803\end{array}$ & $y$ & N & $I$ & & \\
\hline $\begin{array}{l}\text { Sprague Electric Co. } \\
87 \text { Marshall Street } \\
\text { North Adams, Mass. } 01247\end{array}$ & 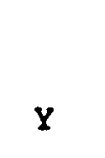 & $Y$ & $I$ & $Y$ & \\
\hline $\begin{array}{l}\text { Dept. of the Army } \\
\text { U.S. Army Material \& } \\
\text { Mechanics Res. Ctr. } \\
\text { Watertown, Mass. } 02172\end{array}$ & $Y$ & $\mathbf{N}$ & G & & \\
\hline $\begin{array}{l}\text { Cooley Dickinson Hospital } \\
\text { Dept. of Radiation Therapy } \\
30 \text { Locust Street } \\
\text { Northampton, Mass. } 01060 \\
\end{array}$ & $Y$ & $\mathbf{N}$ & $\mathbf{M}$ & & \\
\hline
\end{tabular}




\begin{tabular}{|c|c|c|c|c|c|}
\hline \multirow[b]{2}{*}{ LICENSEE NANE AND ADDRESS } & \multicolumn{2}{|c|}{$\begin{array}{c}\text { QUESTION- } \\
\text { NAIRE }\end{array}$} & \multirow{2}{*}{ 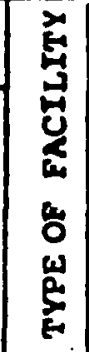 } & \multirow[b]{2}{*}{ 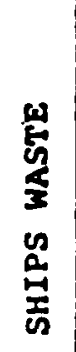 } & \multirow[b]{2}{*}{ COMENTS } \\
\hline & 鵕 & 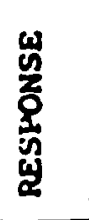 & & & \\
\hline $\begin{array}{l}\text { Joslin Diabetes Foundation, Ind } \\
170 \text { P1lgrim Road } \\
\text { Boston, Mass. } 02215 \text {. }\end{array}$ & $\mathbf{Y}$ & $\mathbf{N}$ & $M$ & & \\
\hline $\begin{array}{l}\text { Wing Memorial Hospital } \\
\text { Dept. of Radiology } \\
\text { Wright Street } \\
\text { Palmer, Mass. } 01069 \\
\end{array}$ & $\mathbf{Y}$ & $\mathbf{Y}$ & $M$ & $\mathbf{Y}$ & \\
\hline $\begin{array}{l}\text { Baird-Atomic Inc. } \\
125 \text { Middlesex Turnpike } \\
\text { Bedford, Mass. } 01730\end{array}$ & $\mathbf{y}$ & $\mathbf{x}$ & I & $\mathbf{Y}$ & \\
\hline $\begin{array}{l}\text { J. B. Thomas Hospital } \\
\text { is King Street } \\
\text { Peabody, Mass. } 01960\end{array}$ & $\mathbf{Y}$ & $\mathbf{Y}$ & $\mathbf{M}$ & $\mathbf{N}$ & \\
\hline $\begin{array}{l}\text { Damon } \\
\text { Damon Diagnostics } \\
115 \text { Fourth Ave. } \\
\text { Neddham Heights, Mass. } 02194\end{array}$ & $\mathbf{Y}$ & $\mathbf{N}$ & $M$ & & \\
\hline $\begin{array}{l}\text { TCM Detectors, Inc. } \\
166 \text { Bear Hill Road } \\
\text { Waltham, Mass. } 02154\end{array}$ & $\mathbf{Y}$ & $\mathrm{N}$ & $I$ & & \\
\hline $\begin{array}{l}\text { INTEREX Corporation } \\
3 \text { Strathmore Road } \\
\text { Natick, Mass. } 02154\end{array}$ & $\mathbf{Y}$ & $\mathbf{N}$ & $I$ & & \\
\hline $\begin{array}{l}\text { tohler Isotope Chem. } \\
49 \text { Jones Road } \\
\text { Waltham, Mass. } 02154\end{array}$ & $\mathbf{Y}$ & $\mathbf{y}$ & $I$ & $\mathrm{~N}$ & \\
\hline $\begin{array}{l}\text { Universal Metal Corp. } \\
\text { P.0. Box } 652 \\
\text { Worcester, Mass. } 98679\end{array}$ & $Y$ & $\mathbf{Y}$ & I & $\mathbf{N}$ & \\
\hline
\end{tabular}




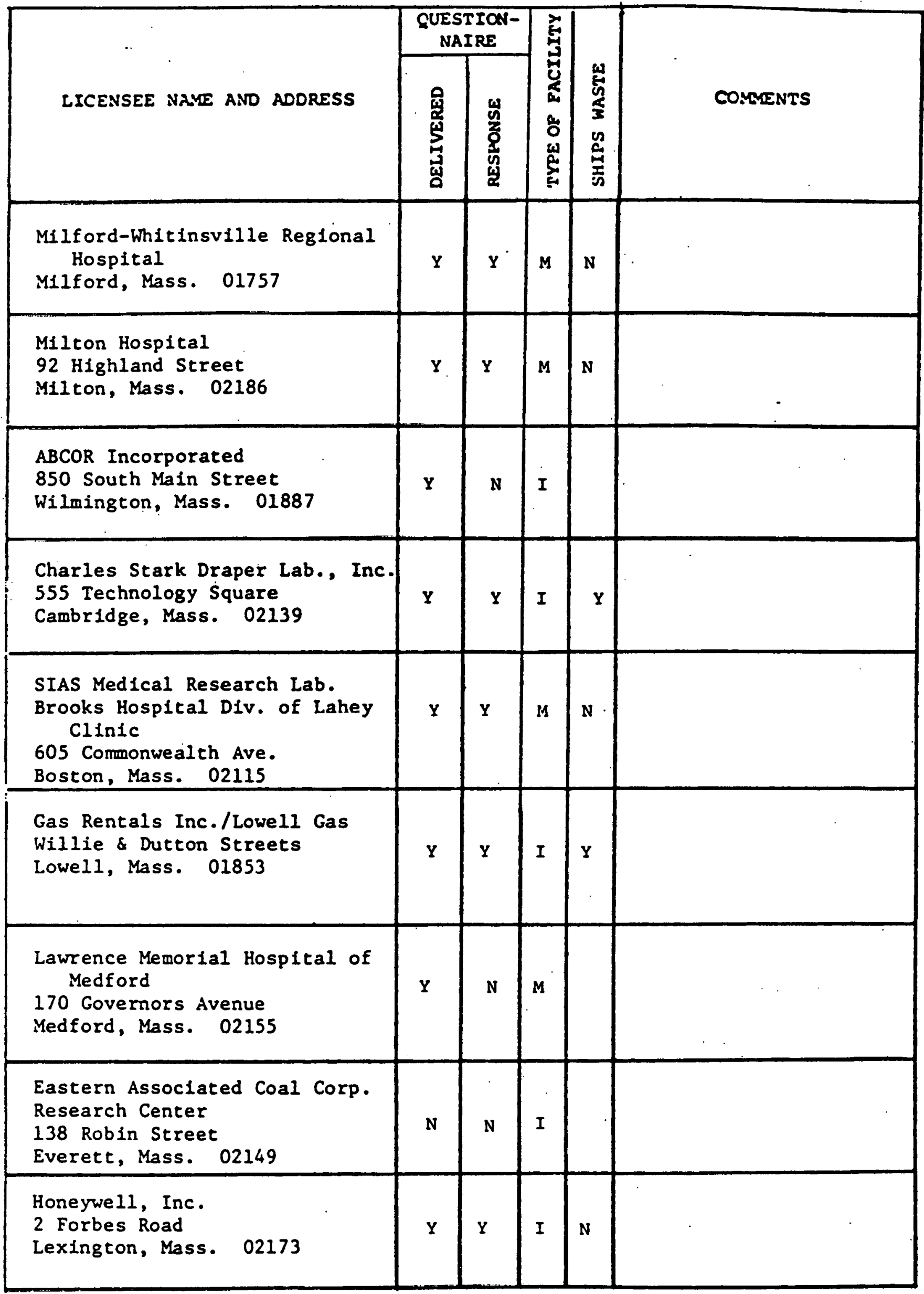




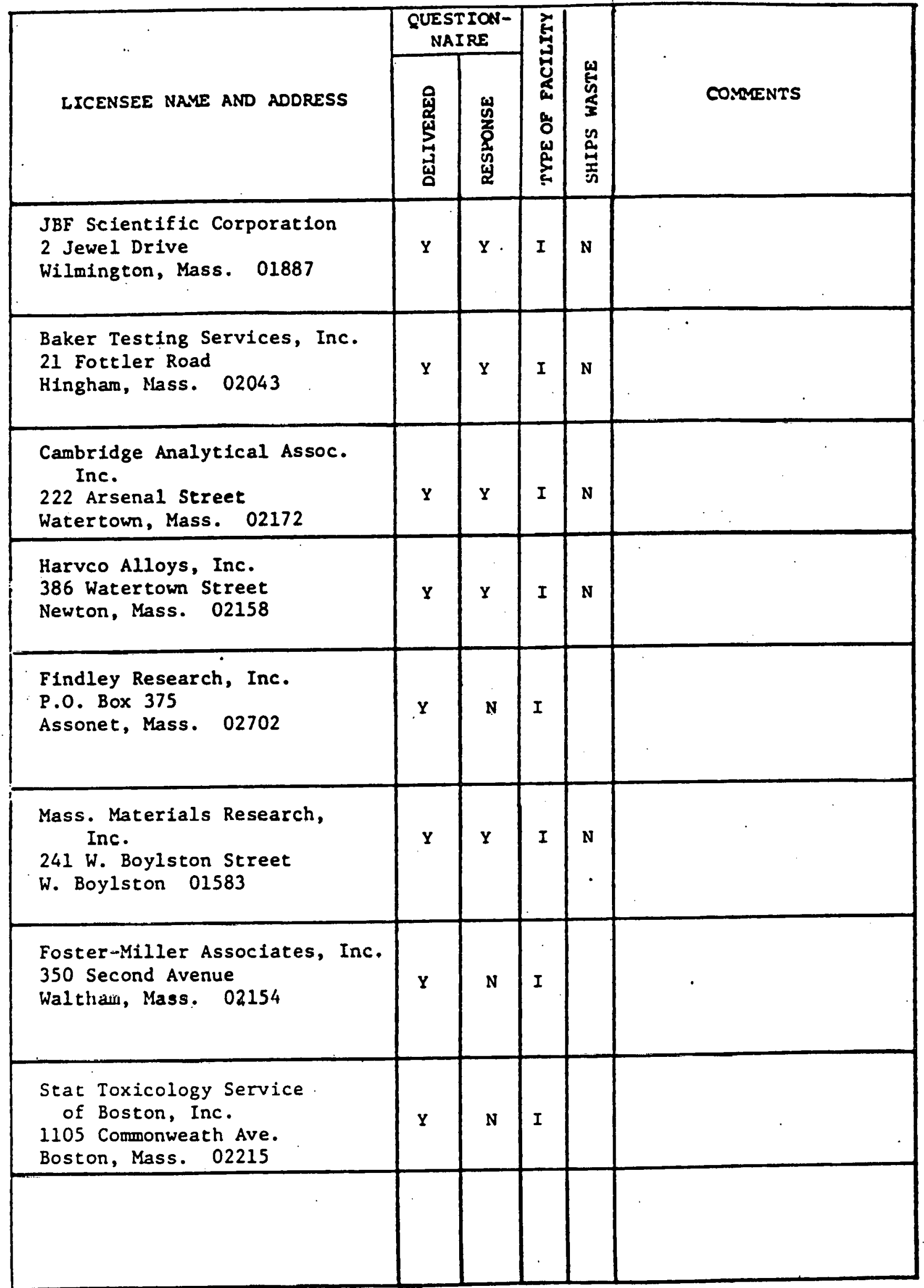




\begin{tabular}{|c|c|c|c|c|c|}
\hline \multirow[b]{2}{*}{ LICENSEE NAYE AND ADDRESS } & \multicolumn{2}{|c|}{$\begin{array}{c}\text { QUESTION- } \\
\text { NAIRE }\end{array}$} & \multirow{2}{*}{ 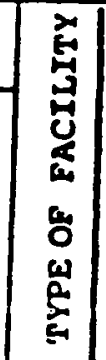 } & \multirow[b]{2}{*}{ 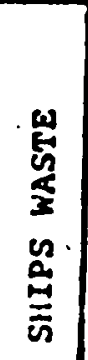 } & \multirow[b]{2}{*}{ COMEnts } \\
\hline & 怘 & 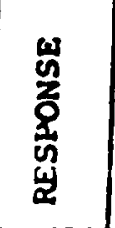 & & & \\
\hline $\begin{array}{l}\text { Digital Equipment Co. } \\
\text { Central Incoming Test (LSI) } \\
180 \text { Milk Street } \\
\text { Westboro, Mass. } 01581\end{array}$ & $y$ & $\mathbf{N}$ & $I$ & & \\
\hline $\begin{array}{l}\text { Ludlow Hospital } \\
14 \text { Chestnut Place } \\
\text { Ludlow, Mass. } 01056\end{array}$ & $\mid Y$ & $\mathbf{N}$ & $M$ & & $\therefore$ \\
\hline $\begin{array}{l}\text { Woburn Sentor High School } \\
\text { Sclence Dept. } \\
88 \text { Montvale Ave. } \\
\text { Woburn, Mass. } 01801\end{array}$ & $y$ & $\mathbf{N}$ & $E$ & & \\
\hline $\begin{array}{l}\text { Penicillin Assays, Inc. } \\
33 \text { Harrison Ave. } \\
\text { Boston, Mass. 02111 }\end{array}$ & $\mathbf{y}$ & $\mathbf{Y}$ & $I$ & $\mathbf{N}$ & \\
\hline $\begin{array}{l}\text { HCHP Central Lab. } \\
\text { Chemistry - Central Lab. } \\
63 \text { Rogers Street } \\
\text { Cambridge, Mass. } 02142\end{array}$ & $\mathbf{Y}$ & $Y$ & $M$ & $\mathbf{N}$ & \\
\hline $\begin{array}{l}\text { Lycott Environmental Research } \\
\text { Co. } \\
600 \text { Charlton Street } \\
\text { Southbridge, Mass. } 01550\end{array}$ & $\mathbf{Y}$ & $\mathbf{Y}$ & I & $\mathbf{N}$ & \\
\hline $\begin{array}{l}\text { Interior, Department of the } \\
\text { U.S. Geological Survey, office } \\
\text { of Marin E. Geology } \\
\text { Building B - Quissett Campus } \\
\text { Woods Hole, Mass. 02543 }\end{array}$ & $\mathbf{x}$ & $\mathbf{N}$ & $G$ & & \\
\hline $\begin{array}{l}\text { Union Carbide Imaging Systems, } \\
\text { Inc. } \\
333 \text { Providence HIghway } \\
\text { Norwood, Mass. } 02062\end{array}$ & $y$ & $\mathbf{N}$ & I & & \\
\hline $\begin{array}{l}\text { Ocean Spray Cranberries, Inc. } \\
\text { Main Street } \\
\text { Hanson, Mass. } 02341\end{array}$ & $\mathbf{N}$ & $\mathbf{N}$ & I & & \\
\hline
\end{tabular}




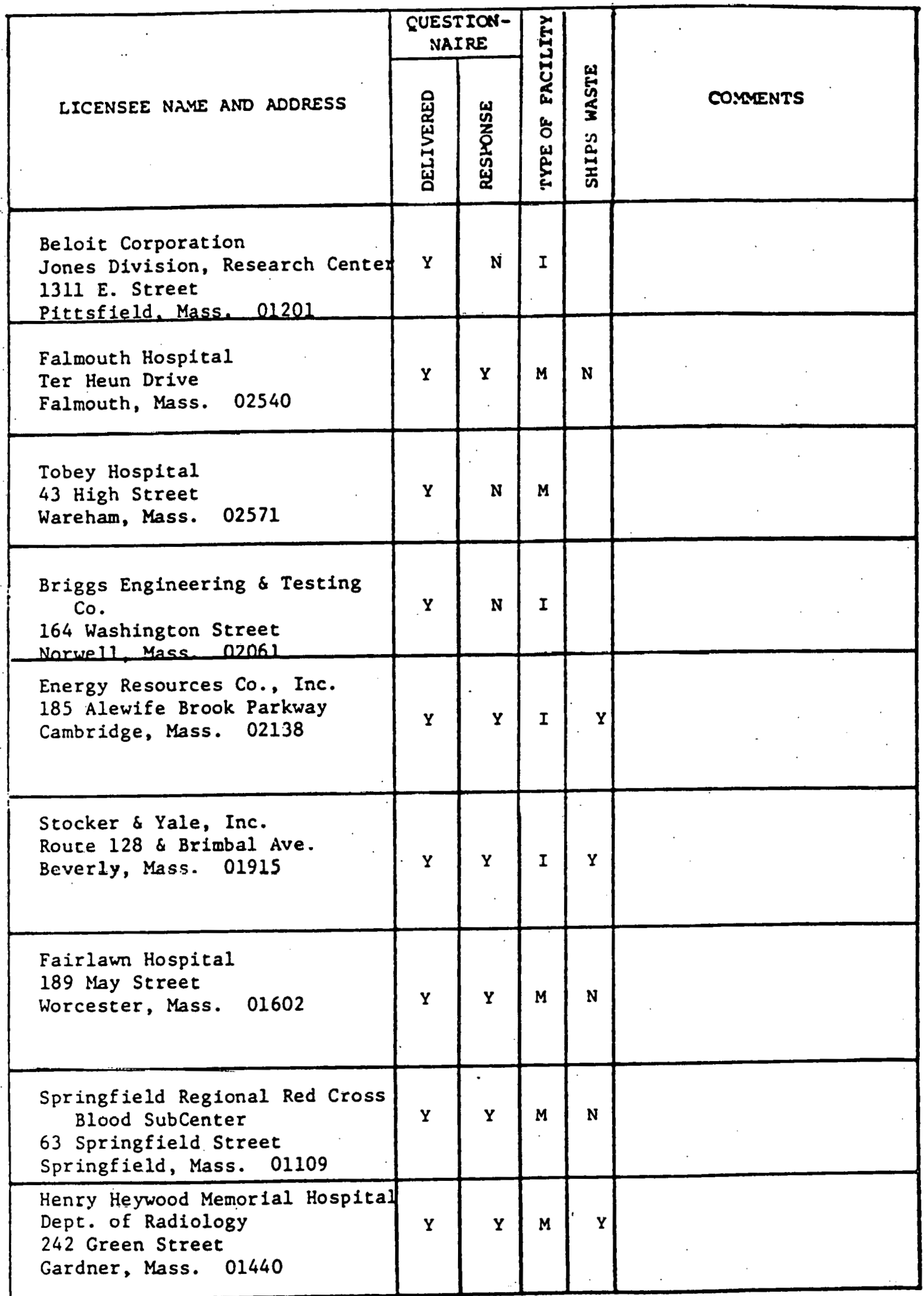




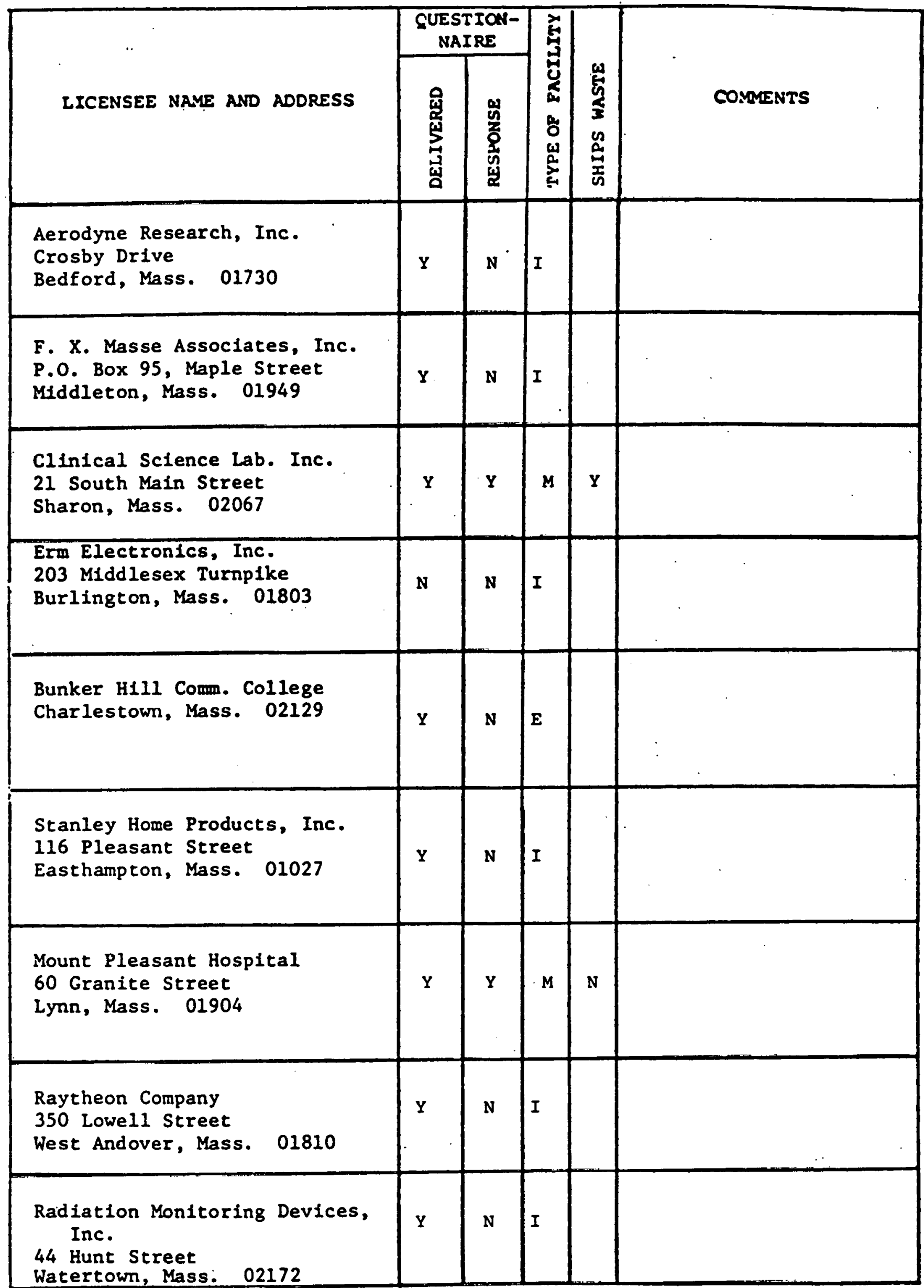




\begin{tabular}{|c|c|c|c|c|c|}
\hline & $\begin{array}{l}\text { QUES } \\
\mathrm{N}\end{array}$ & $\begin{array}{l}\text { ION- } \\
R E\end{array}$ & 营 & & \\
\hline LICENSEE NAME AND ADDRESS & 总 & 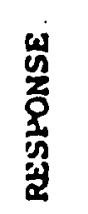 & 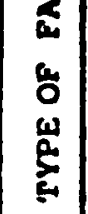 & 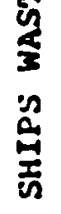 & COMENTS \\
\hline $\begin{array}{l}\text { Me. Auburn Hospital } \\
330 \text { Mt. Auburn Street } \\
\text { Cambridge, Mass. } 02138\end{array}$ & $Y$ & $Y$ & $M$ & $\mathbf{N}$ & \\
\hline $\begin{array}{l}\text { St. John's Hòspital } \\
14 \text { Bartlette Street } \\
\text { Lowell, Mass. } 01852\end{array}$ & $\mathbf{Y}$ & $\mathbf{N}$ & $M$ & & \\
\hline $\begin{array}{l}\text { Cardinal Cushing General } \\
\text { Hospltal } \\
235 \text { Pearl Street } \\
\text { Brockton. Mass. } 02401 \\
\end{array}$ & $\mathbf{Y}$ & $\mathbf{Y}$ & $\mathbf{N}$ & $\mathbf{N}$ & - \\
\hline $\begin{array}{l}\text { St. Vincent Hospital } \\
25 \text { Winthrop Street } \\
\text { Worcester, Mass. } 016.04\end{array}$ & $\mathbf{Y}$ & $\mathbf{N}$ & $M$ & & \\
\hline $\begin{array}{l}\text { Jordan Hospital } \\
\text { Sandwich Street } \\
\text { Plymouth, Mass. } 02360\end{array}$ & $\mathbf{Y}$ & $\mathbf{N}$ & $M$ & & \\
\hline $\begin{array}{l}\text { Univ. of Mass. Medical Center } \\
55 \text { Lake Avenue North } \\
\text { Worchester, Mass. } 01605\end{array}$ & $\mathbf{Y}$ & $\mathbf{N}$ & $M$ & & \\
\hline $\begin{array}{l}\text { Optovac, Inc. } \\
\text { North Brookfield, Mass. } 01535\end{array}$ & $\mathbf{y}$ & $y$ & I & $\mathbf{N}$ & \\
\hline $\begin{array}{l}\text { Eastern Nazarene College } \\
23 \text { East Elm Avenue } \\
\text { Quincy, Mass. 02170 }\end{array}$ & $Y$ & $\mathbf{N}$ & $E$ & & \\
\hline $\begin{array}{l}\text { Mass. College of Pharmacy } \\
179 \text { Longwood Avenue } \\
\text { Boston, Mass. 02115 }\end{array}$ & $Y$ & $\mathbf{Y}$ & $E$ & $Y$ & \\
\hline
\end{tabular}




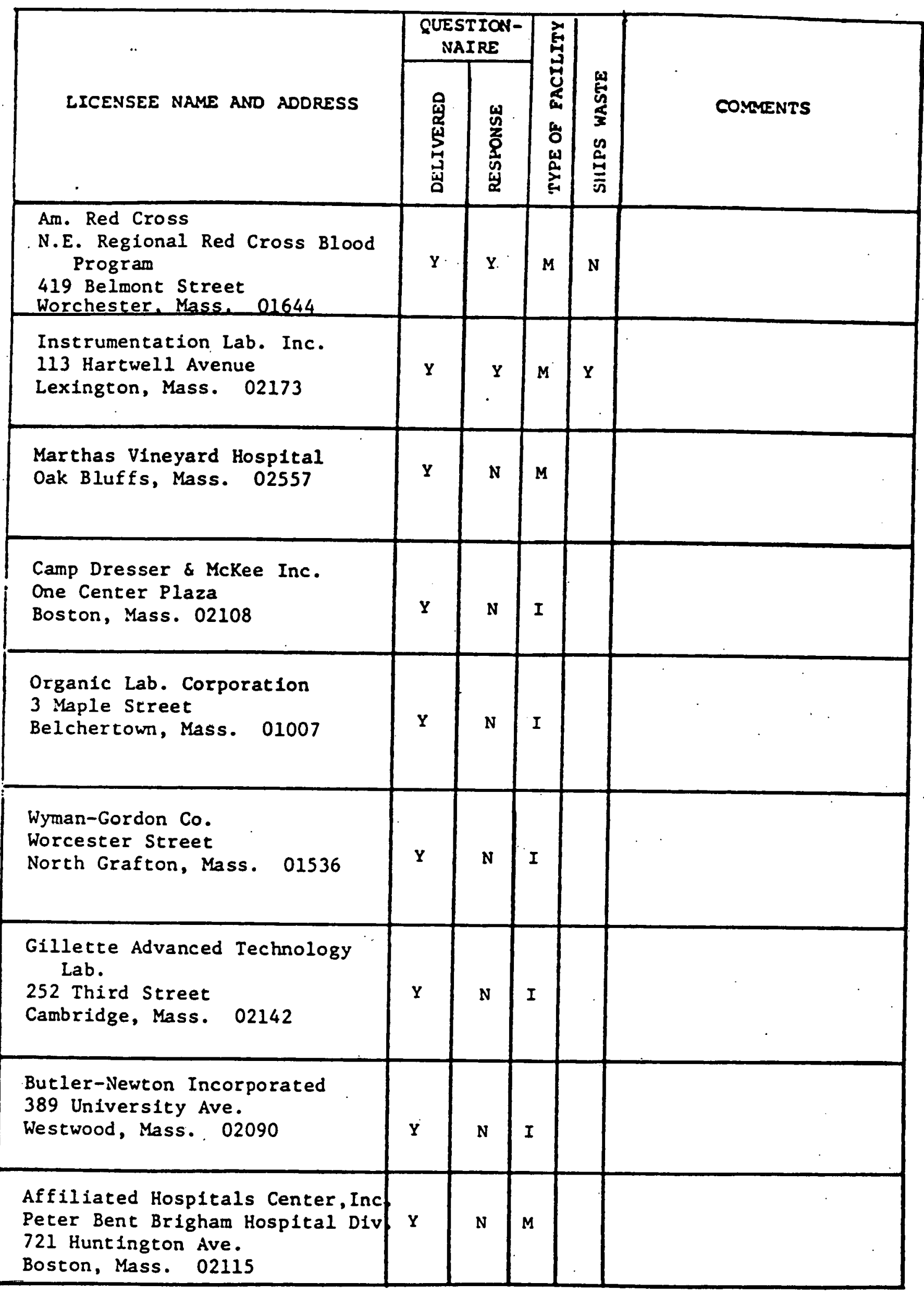




\begin{tabular}{|c|c|c|c|c|c|}
\hline \multirow[b]{2}{*}{ LICENSEE NAME AND ADDRESS } & \multicolumn{2}{|c|}{$\begin{array}{l}\text { QUESTION- } \\
\text { NAIRE }\end{array}$} & \multirow{2}{*}{ 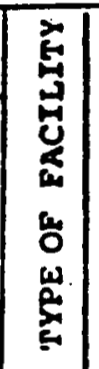 } & \multirow[b]{2}{*}{ 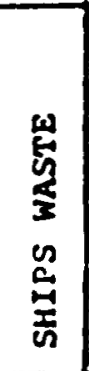 } & \multirow[b]{2}{*}{ COMAENTS } \\
\hline & 总 & 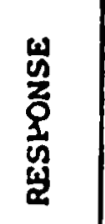 & & & \\
\hline $\begin{array}{l}\text { Mercy Hospital } \\
\text { Carew Street } \\
\text { Springfield, Mass. } 01104\end{array}$ & $\mathbf{Y}$ & $\mathbf{N}$ & M & & \\
\hline $\begin{array}{l}\text { Boston City Hospital } \\
818 \text { Harrison Avenue } \\
\text { Boston, Mass. 02118 }\end{array}$ & $\mathbf{Y}$ & $\mathbf{N}$ & $M$ & & \\
\hline $\begin{array}{l}\text { Harvard University } \\
75 \text { Mt. Auburn Street } \\
\text { Cambridge, Mass. } 02138\end{array}$ & $Y$ & $\mathrm{~N}$ & E & & \\
\hline $\begin{array}{l}\text { Boston University } \\
111 \text { Cummington Street } \\
\text { Boston, Mass. 02215 }\end{array}$ & $Y$ & $\mathrm{~N}$ & $E$ & & . \\
\hline $\begin{array}{l}\text { University of Mass. } \\
\text { Harbour Campus } \\
\text { Dorchester, Mass. } \quad 02125\end{array}$ & $\mathbf{Y}$ & $\mathbf{Y}$ & $\mathbf{E}$ & $\mathbf{N}$ & \\
\hline $\begin{array}{l}\text { Department of the Army } \\
\text { U.S. Army Materials } 6 \\
\text { Mechanics Research Center } \\
\text { Watertown, Mass. } 02172\end{array}$ & $Y$ & $\mathbf{Y}$ & $G$ & $\mathbf{Y}$ & \\
\hline $\begin{array}{l}\text { Baystate Medical Center } \\
759 \text { Chestnut Street } \\
\text { Springfield, Mass. } 01107\end{array}$ & $\mathbf{Y}$ & $\mathbf{N}$ & M & & . \\
\hline $\begin{array}{l}\text { St. Vincent Hospital } \\
25 \text { Winthrop Street } \\
\text { Worcester, Mass. } 01610\end{array}$ & $Y$ & $\cdot y$ & M & $\mathbf{Y}$ & \\
\hline $\begin{array}{l}\text { J. R. M. Bege Co. (The) } \\
4 \text { Court St. Place } \\
\text { Arlington, Mass. } 02174\end{array}$ & $\mathbf{Y}$ & $\mathrm{N}$ & I & & \\
\hline
\end{tabular}




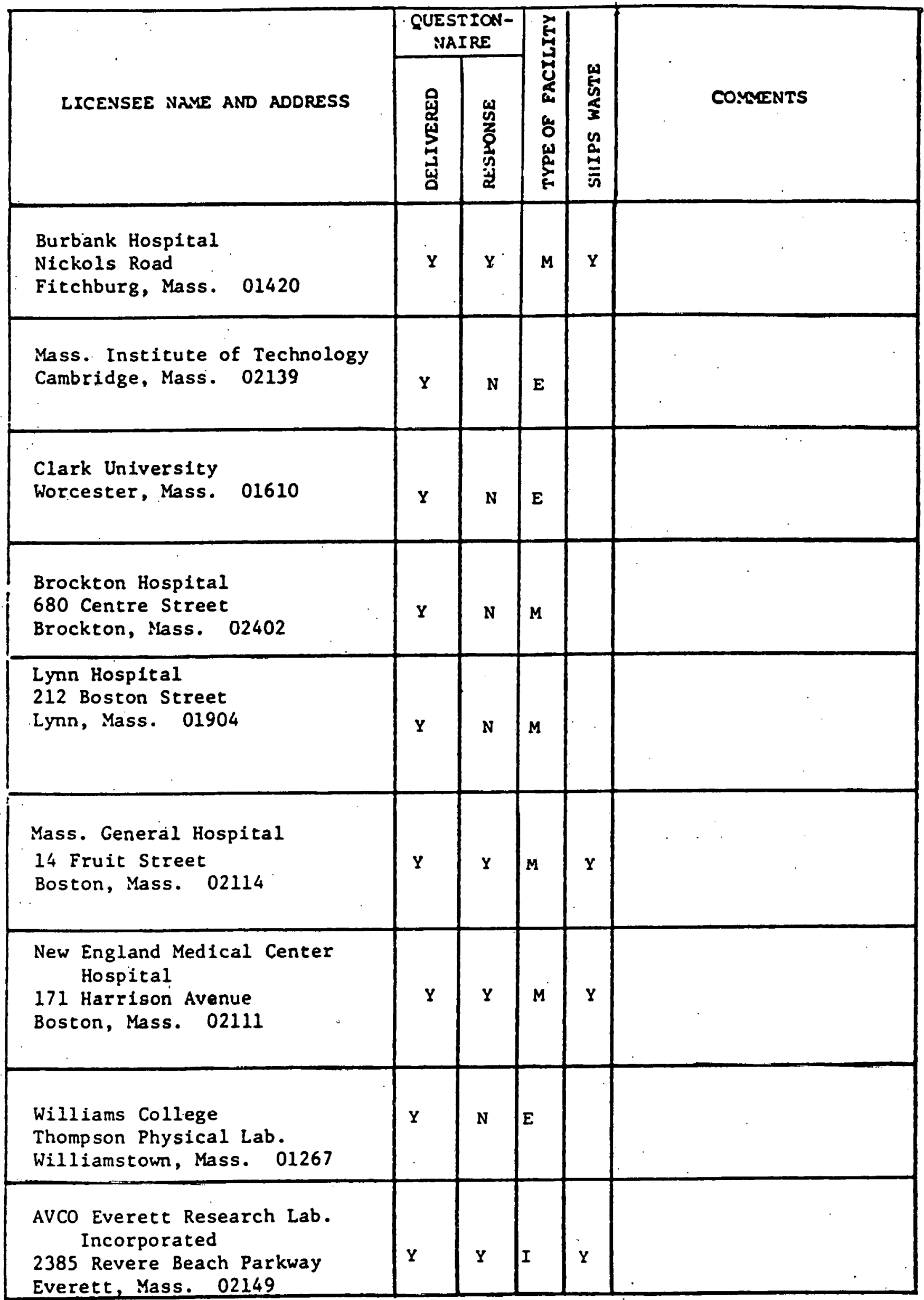




\begin{tabular}{|c|c|c|c|c|c|}
\hline & & & 莺 & & \\
\hline LICENSEE NAME AND ADDRESS & 袬 & 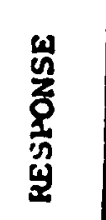 & 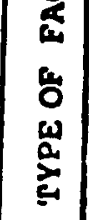 & 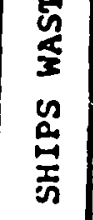 & COMENTS \\
\hline $\begin{array}{l}\text { Holyoke Hospital } \\
575 \text { Beech Street } \\
\text { Holyoke, Mass. } 01040\end{array}$ & $\mathbf{Y}$ & $\mathrm{N}$ & $M$ & & \\
\hline $\begin{array}{l}\text { Lawrence General Hospital } \\
\text { I General Street } \\
\text { Lawrence, Mass. } 01842\end{array}$ & $Y$ & $\mathbf{Y}$ & $\mathbf{M}$ & $\mathbf{N}$ & \\
\hline $\begin{array}{l}\text { Texas Instruments, Inc. } \\
\text { Metallurgical Materials Div. } \\
34 \text { Forest Street } \\
\text { Atrleboro, Mass } 02703\end{array}$ & $\mathbf{Y}$ & $\mathbf{Y}$ & $I$ & $\mathbf{Y}$ & \\
\hline $\begin{array}{l}\text { Northeastern University } \\
360 \text { Huntington Avenue } \\
\text { Boston, Mass. } 02715\end{array}$ & $\mathbf{Y}$ & $\mathbf{Y}$ & $E$ & $\mathbf{Y}$ & 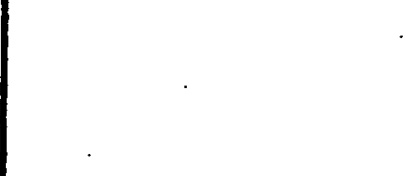 \\
\hline $\begin{array}{l}\text { Wellesley College } \\
\text { Dept. of Physics } \\
\text { Wellesley, Mass. } 02181\end{array}$ & $\mathbf{Y}$ & $\mathrm{N}$ & $E$ & & \\
\hline $\begin{array}{l}\text { Mass. Commonwealth of (The) } \\
\text { Lowell Technological Inst. } \\
\text { Lowell, Mass. } 01854\end{array}$ & $\mathbf{Y}$ & $\mathbf{N}$ & $\mathbf{E}$ & & \\
\hline $\begin{array}{l}\text { Holy Cross, College of the } \\
\text { Worcester, Mass. } 01601 \text {. }\end{array}$ & $\mathbf{Y}$ & $\mathbf{N}$ & $E$ & & \\
\hline $\begin{array}{l}\text { Merrimack College } \\
\text { North Andover, Mass. } 01845\end{array}$ & $y$ & $\mathbf{Y}$ & E & $\mathrm{Y}$ & \\
\hline $\begin{array}{l}\text { Woods Hole Oceanograph1c Inst. } \\
\text { Woods Hole, Mass. } 02543\end{array}$ & $Y$ & $\mathbf{Y}$ & E & $\mathrm{Y}$ & \\
\hline
\end{tabular}




\begin{tabular}{|c|c|c|c|c|c|}
\hline .. & $\begin{array}{l}\text { QUES } \\
\text { NA }\end{array}$ & $\begin{array}{l}\text { ION- } \\
\text { RE }\end{array}$ & 苞 & & \\
\hline LICENSEE NAME AND ADDRESS & 总 & 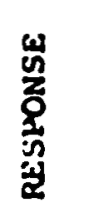 & 告 & 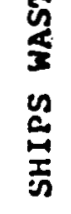 & COMAENTS \\
\hline $\begin{array}{l}\text { Eunice Kennedy Shriver Center } \\
200 \text { Trapelo Road } \\
\text { Waltham, Mass. } 02154\end{array}$ & $\mathbf{Y}$ & $\dot{N}$ & $E$ & & \\
\hline $\begin{array}{l}\text { Medical Imaging Corporation } \\
781 \text { River Street } \\
\text { Haverhill, Mass. } 01830\end{array}$ & $\mathbf{Y}$ & $\mathbf{N}$ & I & & \\
\hline $\begin{array}{l}\text { Ionics, Inc. } \\
65 \text { Grove Street } \\
\text { Watertown, Mass. } 02172\end{array}$ & $\mathbf{Y}$ & $\mathbf{Y}$ & I & $\mathbf{Y}$ & \\
\hline $\begin{array}{l}\text { Draper Brothers Co., Inc. } \\
\text { Felt Service Dept. } \\
28 \text { Draper Lane } \\
\text { Canton Mass } 02021\end{array}$ & $\mathbf{Y}$ & $\mathbf{Y}$ & $I$ & $\mathbf{N}$ & \\
\hline $\begin{array}{l}\text { Monsanto Co. } \\
190 \text { Grochmal Avenue } \\
\text { Indian Orchard, Mass. } 01151\end{array}$ & $\mathbf{Y}$ & $\mathbf{Y}$ & I & $\mathbf{N}$ & \\
\hline $\begin{array}{l}\text { Advanced Mechnical Technology } \\
\quad \text { Inc. } \\
\text { Engineering Dept. } \\
141 \text { California Street } \\
\text { Newton, Mass. } 02158\end{array}$ & $\mathbf{Y}$ & $\mathbf{X}$ & I & N & \\
\hline $\begin{array}{l}\text { St. Luke's Hosptial of } \\
\text { Middleborough } \\
52 \text { Oak Street. } \\
\text { Middleboro, Mass. } 02346\end{array}$ & $\mathrm{y}$ & $\mathbf{N}$ & $M$ & & \\
\hline $\begin{array}{l}\text { Boston State Hospital } \\
\text { Dept. of Mental Health } \\
\text { Boston, Mass. } 02124\end{array}$ & $y$ & $\mathbf{N}$ & M & & \\
\hline $\begin{array}{l}\text { Skinner \& Sherman, Inc. } \\
300 \text { Second Avenue } \\
\text { Waltham, Mass. } 02154\end{array}$ & $\mathbf{Y}$ & $y$ & I & $\mathbf{N}$ & \\
\hline
\end{tabular}




\begin{tabular}{|c|c|c|c|c|c|}
\hline. & $\begin{array}{r}\text { QUES } \\
\text { NA }\end{array}$ & $\begin{array}{l}\text { ION- } \\
\text { RE }\end{array}$ & 总 & & \\
\hline LICENSTEE NAME AND ADDRESS & 怘 & 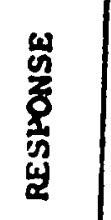 & & 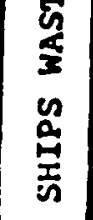 & COMENTS \\
\hline $\begin{array}{l}\text { Penicillin Assays, Inc. } \\
33 \text { Harrison Avenue } \\
\text { Boston, Mass. } 02111\end{array}$ & $\mathbf{Y}$ & $\mathbf{Y}$ & I & $\mathbf{N}$ & \\
\hline $\begin{array}{l}\text { Salem \& Beverly Water Supply } \\
\text { Board } \\
\text { Filtration Plant Laboratory } \\
\text { Beverly, Mass. } 01915\end{array}$ & $\mathbf{Y}$ & $\mathbf{Y}$ & $M$ & $\mathbf{N}$ & \\
\hline $\begin{array}{l}\text { Haverhill Paperboard Corp. } \\
\text { South Kimball Street } \\
\text { Haverhill, Mass. } 01830\end{array}$ & $\mathbf{Y}$ & $\mathbf{N}$ & I & & \\
\hline $\begin{array}{l}\text { Mass. Bay Transportation } \\
\text { Authority } \\
\text { Const. Dir. (Mat. Test. Lab.) } \\
50 \text { High Street } \\
\end{array}$ & $\mathbf{Y}$ & $\mathbf{Y}$ & I & $\mathbf{N}$ & \\
\hline $\begin{array}{l}\text { Waters Associates, Inc. } \\
\text { Analytical Servces Div. R\&D } \\
\text { Dept. } \\
34 \text { Maple Street } \\
\text { Milford, Mass. } 01757\end{array}$ & $\mathbf{Y}$ & $\mathbf{Y}$ & I & $\mathbf{N}$ & \\
\hline $\begin{array}{l}\text { Chloride Pyrotector, Inc. } \\
333 \text { Lincoln Street } \\
\text { Hingham, Mass. } 02043\end{array}$ & $Y$ & $\mathbf{Y}$ & I & $\mathbf{Y}$ & \\
\hline $\begin{array}{l}\text { Solid State Testing Inc. } \\
\text { Environmental Testing Dept. } \\
56 \text { Middlesex Trunpike } \\
\text { Burlington, Mass. } 0803\end{array}$ & $\mathbf{Y}$ & $\mathbf{N}$ & I & & \\
\hline $\begin{array}{l}\text { Winthrop Community Hospital } \\
40 \text { Lincoln Street } \\
\text { Winthrop, Mass. } 02152\end{array}$ & $Y$ & $\mathbf{Y}$ & $M$ & $\mathbf{N}$ & \\
\hline $\begin{array}{l}\text { Gamewell Corporation (The) } \\
7 \text { Industrial Park Road } \\
\text { Medway, Mass. } 02053\end{array}$ & $Y$ & $\mathrm{~N}$ & I & & \\
\hline
\end{tabular}




\begin{tabular}{|c|c|c|c|c|c|}
\hline .. & $\begin{array}{r}\text { QUES } \\
\text { NA } \\
\end{array}$ & $\begin{array}{l}I O N- \\
R E\end{array}$ & $\underset{3}{*}$ & & \\
\hline LICENSEE NAME AND ADDRESS & 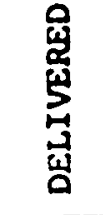 & 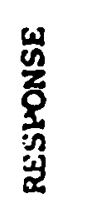 & 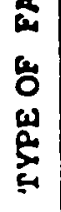 & 茫 & COMAENTS \\
\hline $\begin{array}{l}\text { UNITRODE Corporation } \\
\text { Solid State Products Co. Div. } \\
609 \text { Main Street } \\
\text { Waltham, Mass. } 02154\end{array}$ & $\mathbf{Y}$ & $\mathbf{Y}$ & I & $Y$ & \\
\hline $\begin{array}{l}\text { Corning Glass Works } \\
\text { Biological Products Group } \\
\text { Medfield, Mass. } 02052\end{array}$ & $Y$ & $\mathbf{N}$ & $I$ & & \\
\hline $\begin{array}{l}\text { W. R. Grace \& Co. } \\
\text { Polyfibron Division } \\
\text { Harmony Street } \\
\text { Adams, Mass. } 01220\end{array}$ & $\mathbf{Y}$ & $\mathbf{Y}$ & I & $\mathbf{Y}$ & \\
\hline $\begin{array}{l}\text { Carroll Engineers } \\
200 \text { Andover Street } \\
\text { Ballardvale, Mass. } 01810\end{array}$ & $\mathbf{Y}$ & $\mathbf{N}$ & I & & \\
\hline $\begin{array}{l}\text { Boston Museum of Fine Arts } \\
465 \text { Huntington Avenue } \\
\text { Boston, Mass. } 02115\end{array}$ & $\mathbf{Y}$ & $Y$ & $\mathbf{E}$ & $\mathbf{N}$ & - \\
\hline $\begin{array}{l}\text { Thermo Electron Corp. } \\
\text { Cancer Research Division } \\
45 \text { First Avenue } \\
\text { Waltham, Mass. } 02154\end{array}$ & $\mathbf{Y}$ & $\mathbf{N}$ & I & & \\
\hline $\begin{array}{l}\text { Cambridge Hospital (The) } \\
\text { Nuclear Medicine Lab. Radiology } \\
\text { Department } \\
1493 \text { Cambridge Street } \\
\text { Cambridge, Mass. } 02139\end{array}$ & $Y$ & $\mathbf{N}$ & $\mathbf{M}$ & & - \\
\hline $\begin{array}{l}\text { Charles Choate Memorial Hospital } \\
21 \text { Warren Avenue } \\
\text { Woburn, Mass. } 01801\end{array}$ & $\mathbf{Y}$ & $\mathbf{Y}$ & $\mathbf{M}$ & $\mathrm{N}$ & \\
\hline $\begin{array}{l}\text { Bridgewater State College } \\
\text { Biology, Chemistry and Physics } \\
\text { Departments } \\
\text { Bridgewater, Mass. } 02324\end{array}$ & $Y$ & $\mathbf{N}$ & $\mathbf{E}$ & & \\
\hline
\end{tabular}




\begin{tabular}{|c|c|c|c|c|c|}
\hline & $\begin{array}{r}\text { SUES } \\
\text { NA }\end{array}$ & $\begin{array}{l}\text { ION- } \\
R E\end{array}$ & 密 & & \\
\hline LICENSEE NAME AND ADDRESS & 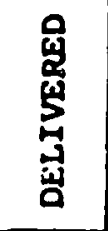 & 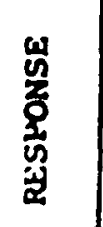 & a & 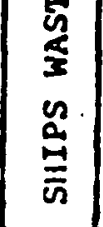 & COMENTS \\
\hline $\begin{array}{l}\text { Leominster Hospital } \\
\text { Hospital Road } \\
\text { Leominster, Mass. } 01453\end{array}$ & $\mathbf{Y}$. & $\dot{N}$ & $M$ & & . \\
\hline $\begin{array}{l}\text { Leonard Morse Hospital } \\
67 \text {. Union Street } \\
\text { Natick, Mass. } 01760\end{array}$ & $x$ & $\mathbf{Y}$ & $M$ & $\mathbf{N}$ & - \\
\hline $\begin{array}{l}\text { Melrose-Wakef leld Hospital } \\
585 \text { Lebanon Street } \\
\text { Melrose, Mass. } 02176\end{array}$ & $Y$ & $\mathbf{N}$ & $M$ & & \\
\hline $\begin{array}{l}\text { Waltham Hospital (The) } \\
\text { Hope Avenue } \\
\text { Watham, Mass. } 02154\end{array}$ & $\mathbf{Y}$ & $\mathbf{Y}$ & $\mathbf{M}$ & $\mathbf{N}$ & \\
\hline $\begin{array}{l}\text { Morton Hospital } \\
\text { Dept. of Radiology } \\
\text { 88 Wastifington Street } \\
\text { Taunton, Mass. } 02780\end{array}$ & $Y$ & $\mathbf{N}^{\circ}$ & $M$ & & \\
\hline $\begin{array}{l}\text { Symmes Hospital } \\
\text { Arlington, Mass. } 02174\end{array}$ & $\mathbf{Y}$ & $\mathbf{N}$ & $M$ & & \\
\hline $\begin{array}{l}\text { CIS Radiopharmaceuticals, Inc. } \\
\text { S De Angelo Drive } \\
\text { Bedford, Mass. } 01730\end{array}$ & $\mathbf{Y}$ & $\mathbf{N}$ & I & & \\
\hline $\begin{array}{l}\text { Wheaton College } \\
\text { E. Main Street } \\
\text { Norton, Mass. } 02766\end{array}$ & $\mathbf{Y}$ & $\mathrm{N}$ & $E$ & & \\
\hline $\begin{array}{l}\text { St. Vincent Hospital } \\
\text { Chemistry Dept. } \\
\text { Worcester, Mass. } 01604\end{array}$ & $\mathbf{Y}$ & $\mathbf{N}$ & $M$ & & \\
\hline
\end{tabular}




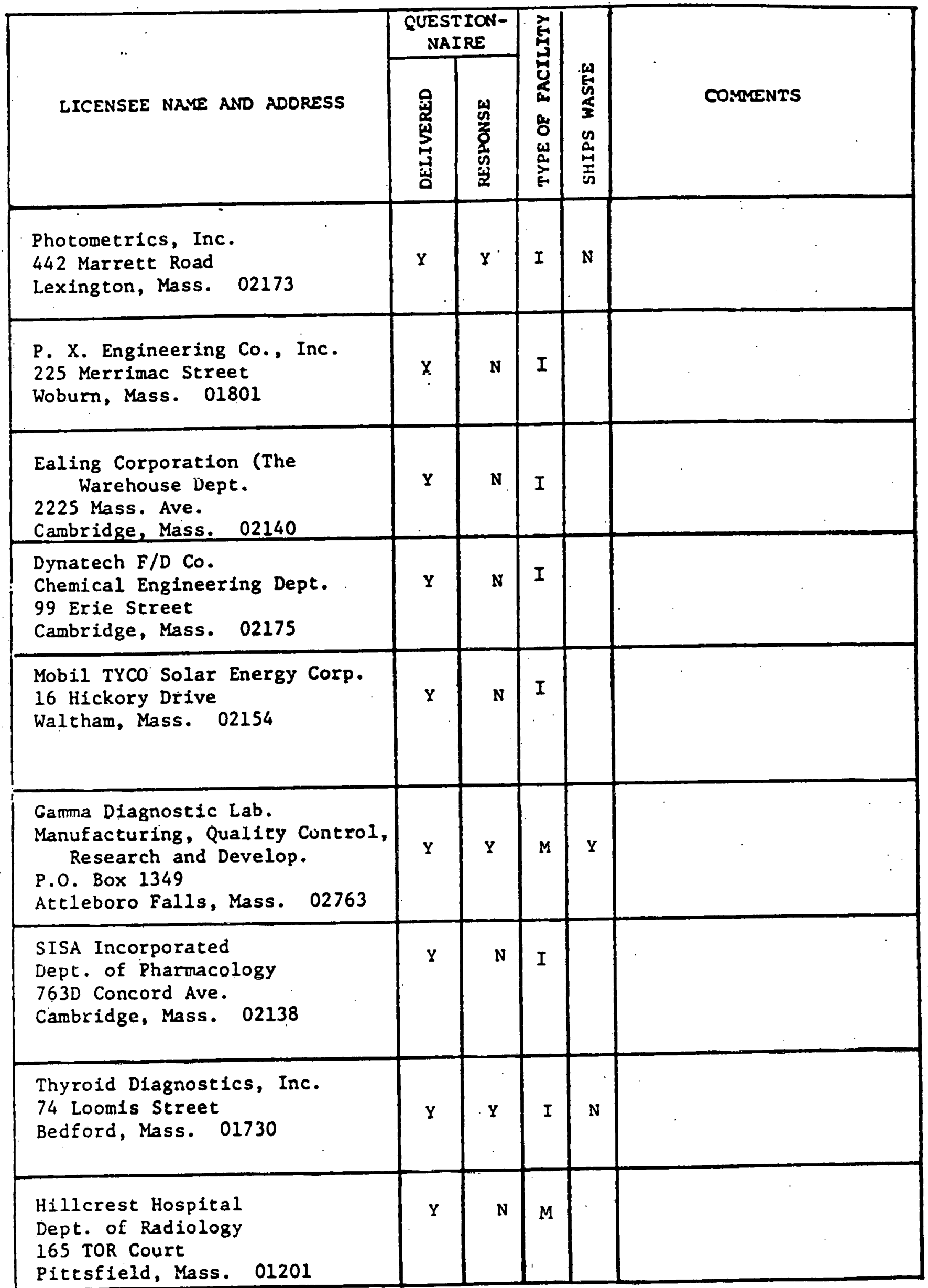




\begin{tabular}{|c|c|c|c|c|c|}
\hline .. & $\begin{array}{r}\text { QUES } \\
\text { NA }\end{array}$ & $\begin{array}{l}\text { ION- } \\
\text { RE }\end{array}$ & 离 & & \\
\hline LICENSEE NAME AND ADDRESS & 最 & 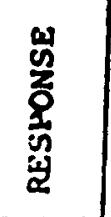 & 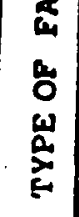 & 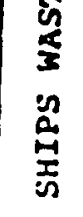 & COMENTS \\
\hline $\begin{array}{l}\text { Boston Biomedical Research Inst. } \\
20 \text { Staniford Street } \\
\text { Boston, Mass. } 02114\end{array}$ & $\mathbf{Y}$ & $\dot{N}$ & $\mathbf{M}$ & & \\
\hline $\begin{array}{l}\text { Mass. Univ. of Medical Center } \\
55 \text { Lake Ave. North } \\
\text { Worcester, Mass. } 01605\end{array}$ & $\mathbf{Y}$ & N & $\mathbf{M}$ & & \\
\hline $\begin{array}{l}\text { Southeastern Mass. University } \\
\text { Old Westport Road } \\
\text { N. Dartmoutin, Mass. } 02747\end{array}$ & $\mathbf{Y}$ & $\mathbf{Y}$ & $E$ & $\mathbf{Y}$ & \\
\hline $\begin{array}{l}\text { AMICON Corp. } \\
25 \text { Hartwell Avenue } \\
\text { Lexington, Mass. } 02173\end{array}$ & $\mathbf{Y}$ & $Y$ & $I$ & $\mathbf{Y}$ & \\
\hline $\begin{array}{l}\text { Emerson Hospital } \\
\text { Old Road at Nine Acre Corner } \\
\text { Concord, Mass. } 07142\end{array}$ & $\mathbf{Y}$ & $\mathbf{N}$ & $\mathbf{M}$ & $\mathbf{Y}$ & \\
\hline $\begin{array}{l}\text { Travenol Lab., Inc. } \\
\text { Clinical Assays Div. } \\
620 \text { Memorial Drive } \\
\text { Cambridge, Mass. } 02130\end{array}$ & $\mathbf{Y}$ & $\mathbf{Y}$ & I & $\mathbf{Y}$ & \\
\hline $\begin{array}{l}\text { Bon Secours Hospital } \\
70 \text { East Street } \\
\text { Methuen, Mass. } 01844\end{array}$ & $Y$ & $Y$ & M & N & \\
\hline $\begin{array}{l}\text { Our Lady of the Elms, College of } \\
291 \text { Springfield Street } \\
\text { Chicopee, Mass. } 01013\end{array}$ & $Y$ & $Y$ & $\mathbf{E}$ & $Y$ & \\
\hline $\begin{array}{l}\text { Sancta Maria Hospital } \\
799 \text { Concord Avenue } \\
\text { Cambridge, Mass. } 02138\end{array}$ & $\mathbf{Y}$ & $\mathrm{N}$ & M & & - \\
\hline
\end{tabular}




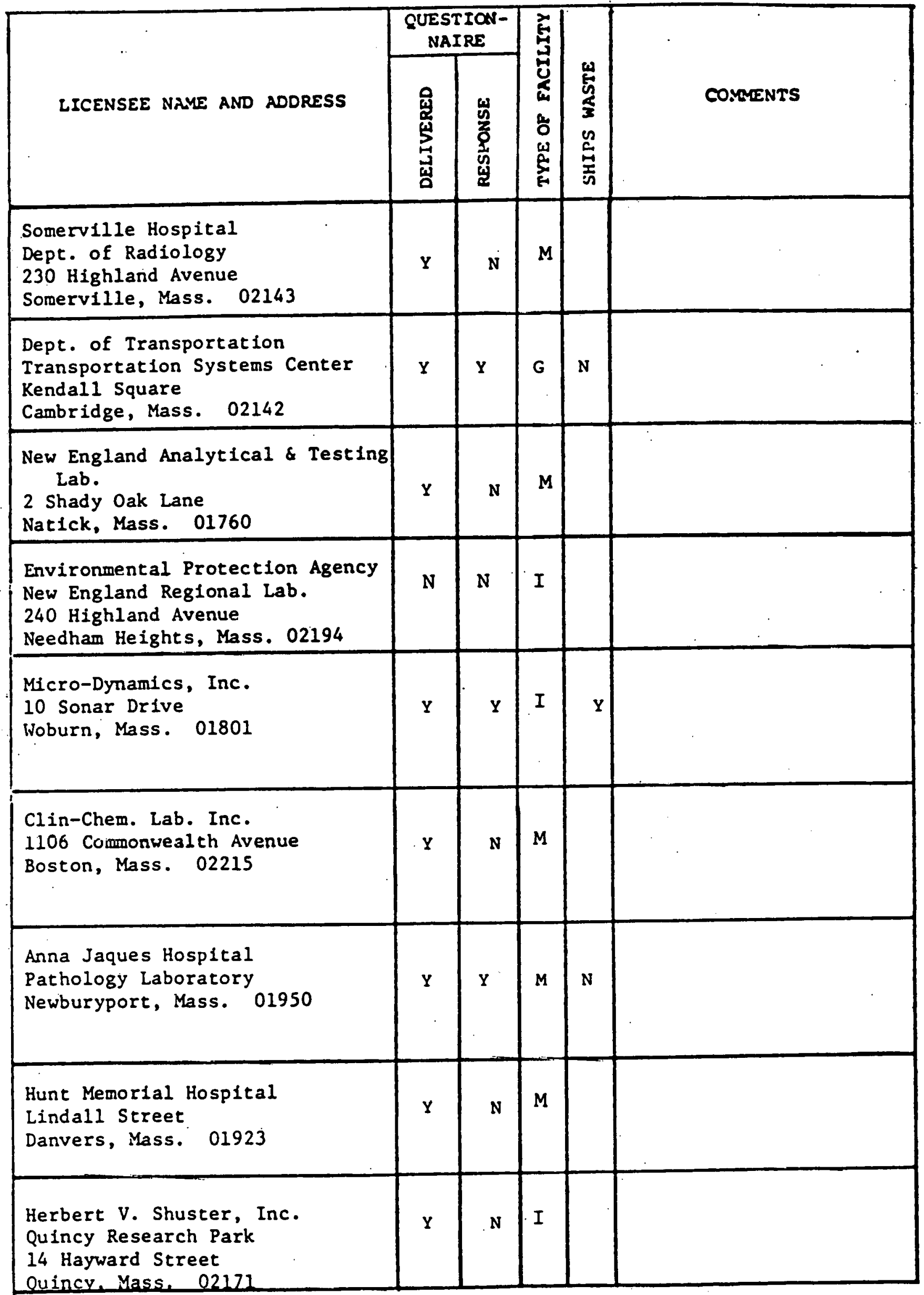




\begin{tabular}{|c|c|c|c|c|c|}
\hline \multirow[b]{2}{*}{ LICENSEE NAYE AND ADDRESS } & \multicolumn{2}{|c|}{$\begin{array}{l}\text { WUESA DUN- } \\
\text { NAI } 3 E\end{array}$} & \multirow{2}{*}{ 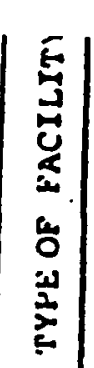 } & \multirow[b]{2}{*}{ 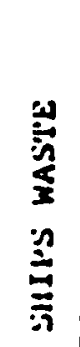 } & \multirow[b]{2}{*}{ CC.MENTS } \\
\hline & 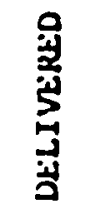 & 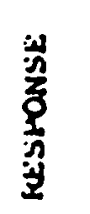 & & & \\
\hline $\begin{array}{l}\text { Baystate Medical Center } \\
\text { Wesson Memorial Unit } \\
140 \text { High Street } \\
\text { Springfield, Mass. } 01105\end{array}$ & $\mathbf{Y}$ & $\mathbf{N}$ & M & & \\
\hline $\begin{array}{l}\text { J. G. Sylvester Assoc., Inc. } \\
900 \text { Hingham Street } \\
\text { Rockland, Mass. } 02370\end{array}$ & $\mathbf{Y}$ & $\mathbf{N}$ & I & & \\
\hline $\begin{array}{l}\text { Department of the Army } \\
\text { USA Natick Laboratories } \\
\text { Natick, Mass. } 01760\end{array}$ & $\mathbf{Y}$ & $\mathbf{N}$ & G & & \\
\hline $\begin{array}{l}\text { Department of the Army } \\
575 \text { Albany Street } \\
\text { Boston, Mass. } 02118\end{array}$ & $\mathbf{Y}$ & $\mathbf{N}$ & G & & \\
\hline $\begin{array}{l}\text { Sprague Electric Company } \\
\text { Marshall Street } \\
\text { North Adams, Mass. } 01248\end{array}$ & $Y$ & $\mathbf{Y}$ & I & $Y$ & \\
\hline $\begin{array}{l}\text { Lowell General Hospital } \\
\text { X-Ray Department } \\
295 \text { Varnum Avenue } \\
\text { Lowell, Mass. } 01854\end{array}$ & $\mathbf{Y}$ & $\mathbf{N}$ & $M$ & & \\
\hline $\begin{array}{l}\text { Monsanto Company } \\
\text { Springfield Plant } \\
730 \text { Worcester Street } \\
\text { Indian Orchard, Mass. } 01051\end{array}$ & $\mathbf{Y}$ & $\mathrm{N}$ & I & & . \\
\hline $\begin{array}{l}\text { Crane Company - Indian Or- } \\
\text { chard Plant } \\
\text { Radiographic Laboratory } \\
203 \text { Hampshire Street } \\
\text { Indian Orchard, Mass. 01151 }\end{array}$ & $\mathbf{Y}$ & $\mathbf{N}$ & I & & \\
\hline $\begin{array}{l}\text { Marine Biological Laboratory } \\
\text { Department of Radiology } \\
\text { M. B. L. Street } \\
\text { Woods Hole, Mass. } 02543\end{array}$ & $Y$ & $\mathbf{N}$ & I & & \\
\hline
\end{tabular}




\begin{tabular}{|c|c|c|c|c|c|c|}
\hline \multirow[b]{2}{*}{ LICENSEE NAYE AND ADDRESS } & \multicolumn{2}{|c|}{$\begin{array}{l}\text { CUESTION- } \\
\text { NAIPE }\end{array}$} & \multirow{2}{*}{ 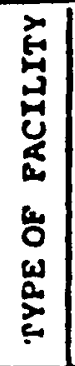 } & \multirow[b]{2}{*}{ 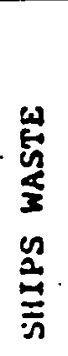 } & \multirow[b]{2}{*}{ COMENTS } & \\
\hline & 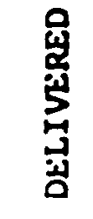 & 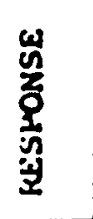 & & & & ‘ \\
\hline $\begin{array}{l}\text { Beverly Hospital } \\
\text { Department of Radiology } \\
\text { Herrick Street } \\
\text { Beverly, Mass. } 01915\end{array}$ & $\mathbf{Y}$ & $\mathbf{Y}$ & $\mathbf{M}$ & $\mathbf{N}$ & & \\
\hline $\begin{array}{l}\text { Microwave Associates, Inc. } \\
\text { South Avenue } \\
\text { Burlington, Mass, } 01803\end{array}$ & $\mathbf{Y}$ & $\mathbf{Y}$ & I & $\mathbf{Y}$ & & \\
\hline $\begin{array}{l}\text { LFE Corporation } \\
\text { Process Control Division } \\
\text { 1601 Trapelo Road } \\
\text { Waltham, Mass. } 02154\end{array}$ & $\mathbf{Y}$ & $Y$ & $\mathbf{I}$ & $\mathbf{Y}$ & $\cdot$ & \\
\hline $\begin{array}{l}\text { Baystate Medical Center } \\
\text { Springfield \& Wesson Wopeñ's } \\
759 \text { Chestnut Street } \\
\text { Springfield, Mass. } 01107 \\
\end{array}$ & $\mathbf{Y}$ & $\mathbf{N}$ & M & & . & \\
\hline $\begin{array}{l}\text { American Sandpaper Company } \\
\text { Production Department } \\
\text { Rockland, Mass. } 02370\end{array}$ & $\mathbf{Y}$ & $\mathbf{N}$ & $I$ & & & \\
\hline $\begin{array}{l}\text { Smith College } \\
\text { Clark Science Center } \\
\text { Northhampton, Mass. } 01060\end{array}$ & $\mathbf{Y}$ & $Y$ & $\mathbf{E}$. & $\mathbf{Y}$ & & \\
\hline $\begin{array}{l}\text { Gillette Company } \\
\text { Gillette Park } \\
\text { Bostnn, Mass. } 02106\end{array}$ & $\mathbf{Y}$ & $\mathbf{Y}$ & $I$ & & & \\
\hline $\begin{array}{l}\text { Baird-Atomic, Inc. } \\
125 \text { Middlesex Turnpike } \\
\text { Bedford, Mass. } 01730\end{array}$ & $\mathbf{Y}$ & $\mathrm{N}$ & $I$ & & & \\
\hline $\begin{array}{l}\text { Arthur D. Little, Inc. } \\
\text { Life Sciences Division } \\
35 \text { Acorn Park } \\
\text { Cambridge, Mass. } 02140\end{array}$ & $\mathbf{Y}$ & $\mathrm{N}$ & $I$ & & & \\
\hline
\end{tabular}




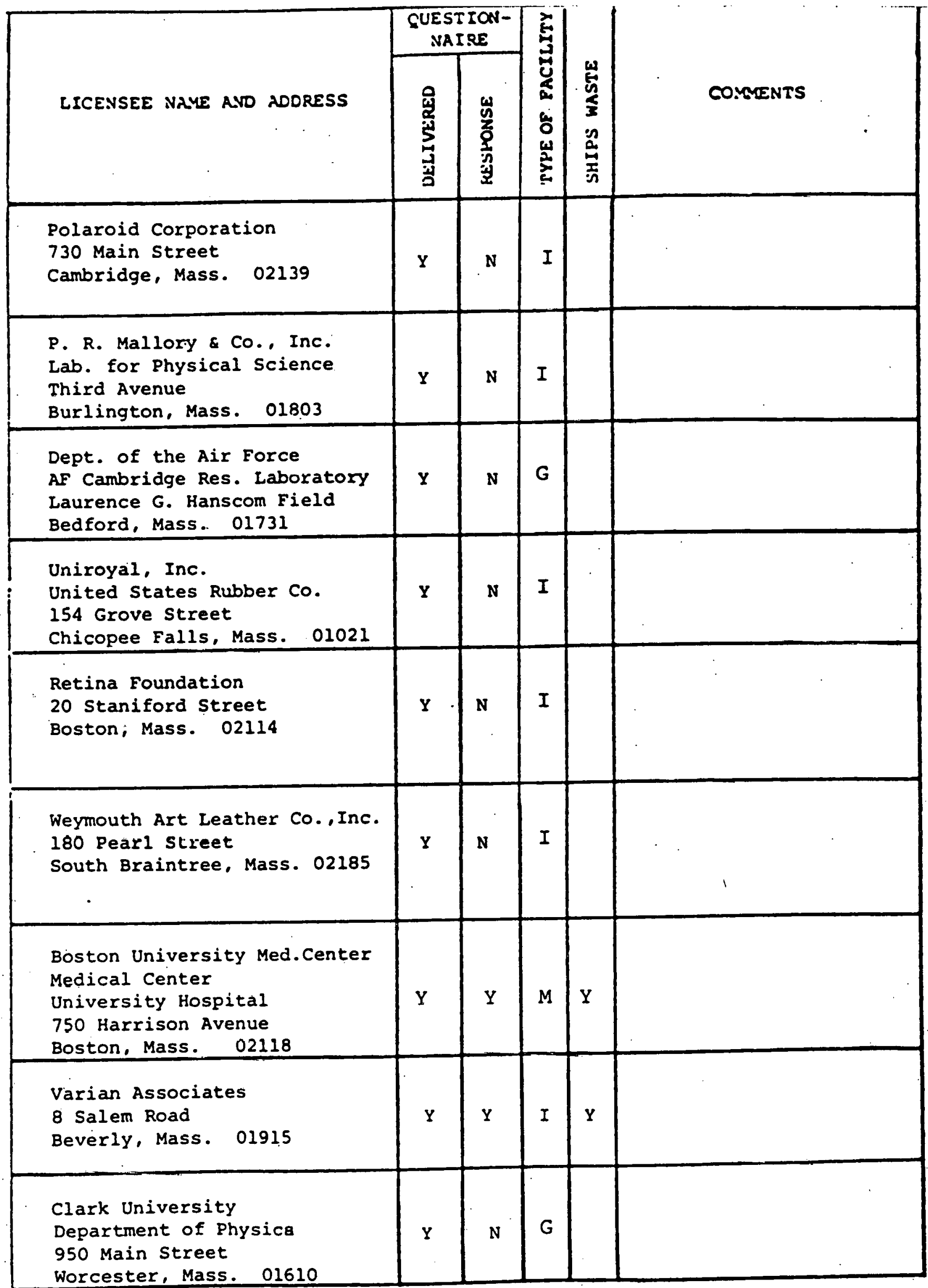




\begin{tabular}{|c|c|c|c|c|c|}
\hline & $\begin{array}{r}\text { SUES } \\
\text { NA } \\
\end{array}$ & $\begin{array}{l}\text { ION- } \\
\text { SRE }\end{array}$ & 总 & & 1 \\
\hline LICENSEE NAYE AND ADDRESS & 聯 & 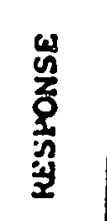 & 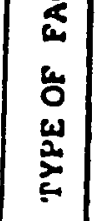 & 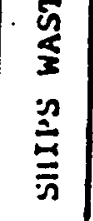 & COMEENTS \\
\hline $\begin{array}{l}\text { Lahey Clinic Foundation } \\
\text { Dept. of Diagnostic Radiology } \\
605 \text { Commonwealth Avenue } \\
\text { Boston, Mass. } 02215 \\
\end{array}$ & $\mathbf{Y}$ & $Y$ & $M$ & $\mathbf{Y}$ & \\
\hline $\begin{array}{l}\text { General Electric Co. } \\
\text { One Plastics Avenue } \\
\text { P1ttsfield, Mass. } 01201\end{array}$ & $y$ & $\mathbf{N}$ & I & & \\
\hline $\begin{array}{l}\text { Western Electric Co. } \\
1600 \text { Osgood Street } \\
\text { North Andover, Mass. } 01845\end{array}$ & $y$ & $\mathbf{N}$ & $I$ & & \\
\hline $\begin{array}{l}\text { Interstate Uniform Services Corp } \\
295 \text { Parker Street } \\
\text { Indian Orchard, Mass. } 01151\end{array}$ & $\mathbf{Y}$ & $\mathbf{N}$ & $I$ & & \\
\hline $\begin{array}{l}\text { Foxboro Company (The) } \\
\text { Neponset Avenue } \\
\text { Foxboro, Mass. } 02035\end{array}$ & $\mathbf{Y}$ & $\mathbf{N}$ & $I$ & & \\
\hline $\begin{array}{l}\text { Mass. General Hospital } \\
\text { Physics Research Lab. } \\
\text { Fruit Street } \\
\text { Boston, Mass. } 02114\end{array}$ & $\mathbf{Y}$ & $\mathbf{N}$ & $M$ & & \\
\hline $\begin{array}{l}\text { Factory Mutual Research Corp. } \\
1151 \text { Boston-Providence Turnpike } \\
\text { Norwood, Mass. } 02062\end{array}$ & $\mathrm{Y}$ & $\mathbf{N}$ & $I$ & & \\
\hline $\begin{array}{l}\text { Pondville Hospital } \\
\text { Nuclear Medicine } \\
\text { Walpole, Mass. } 02081\end{array}$ & $Y$ & $\mathbf{Y}$ & $M$ & $\mathbf{N}$ & \\
\hline $\begin{array}{l}\text { Carney Hospital (The) } \\
\text { Radioisotope Lab. } \\
2100 \text { Dorchester Avenue } \\
\text { Boston, Mass. 02124 }\end{array}$ & $Y$ & $Y$ & M & $Y$ & . \\
\hline
\end{tabular}




\begin{tabular}{|c|c|c|c|c|c|}
\hline & $\begin{array}{r}\text { QUE } \\
N\end{array}$ & $\begin{array}{l}\text { ION- } \\
\text { RE }\end{array}$ & 点 & & \\
\hline LICENSEE NAYE AVD ADDRESS & 题 & 幽 & $\begin{array}{l}a \\
a \\
a \\
\omega \\
a \\
a \\
c\end{array}$ & 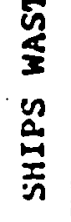 & COMLENTS \\
\hline $\begin{array}{l}\text { RCA Corporation } \\
\text { Burlington, Mass. } 01801\end{array}$ & $\mathbf{Y}$ & $Y$ & $I$ & $\mathbf{N}$ & \\
\hline $\begin{array}{l}\text { Mass. College of Pharmacy } \\
179 \text { Longwood Avenue } \\
\text { Boston, Mass. } 02115\end{array}$ & $Y$ & $\mathbf{N}$ & $\mathbf{M}$ & & \\
\hline $\begin{array}{l}\text { llolyoke Hospital } \\
\text { Radiology \& Pathology Depts. } \\
575 \text { Beech Street } \\
\text { Holyoke, Mass. } 01040\end{array}$ & $y$ & $\mathbf{N}$ & $\mathbf{M}$ & & \\
\hline $\begin{array}{l}\text { OMNI-Wave Electronfes Corp. } \\
\text { Blackburn Industrial PK., P.O. } \\
\text { Gloucester, Mass. } 01930\end{array}$ & $\mathbf{Y}$ & $\mathbf{N}$ & $I$ & & $\therefore$ \\
\hline $\begin{array}{l}\text { Stone \&ebster Engineering Corp } \\
225 \text { Franklin Street } \\
\text { Boston, Mass. } 02107\end{array}$ & $\mathbf{Y}$ & $\mathbf{Y}$ & $I$ & $\mathbf{N}$ & \\
\hline $\begin{array}{l}\text { Attleboro Fire Dept. } \\
100 \text { Union Street } \\
\text { Attleboro, Mass. } 02703\end{array}$ & $\mathbf{Y}$ & $\mathbf{N}$ & $I$ & & \\
\hline $\begin{array}{l}\text { Anna Maria College } \\
\text { Biology and Chemistry Depts. } \\
\text { Paxton, Mass. } 01612\end{array}$ & $\mathbf{Y}$ & $\mathbf{N}$ & G & & \\
\hline $\begin{array}{l}\text { Charlton Memorial Hospltal, Inc. } \\
\text { Dept. of Radiology \& Nuclear Med } \\
\text { Highland Ave., at New Boston } \\
\text { Fall River, Mass. } 02720\end{array}$ & $Y$ & $\mathbf{N}$ & M & & \\
\hline $\begin{array}{l}\text { St. Anne's Hospital } \\
\text { Dept. of Nuclear Medicine } \\
795 \text { Middle Street } \\
\text { Fall River, Mass. } 02722\end{array}$ & $\mathbf{Y}$ & $\mathbf{N}$ & $\mathbf{M}$ & & \\
\hline
\end{tabular}




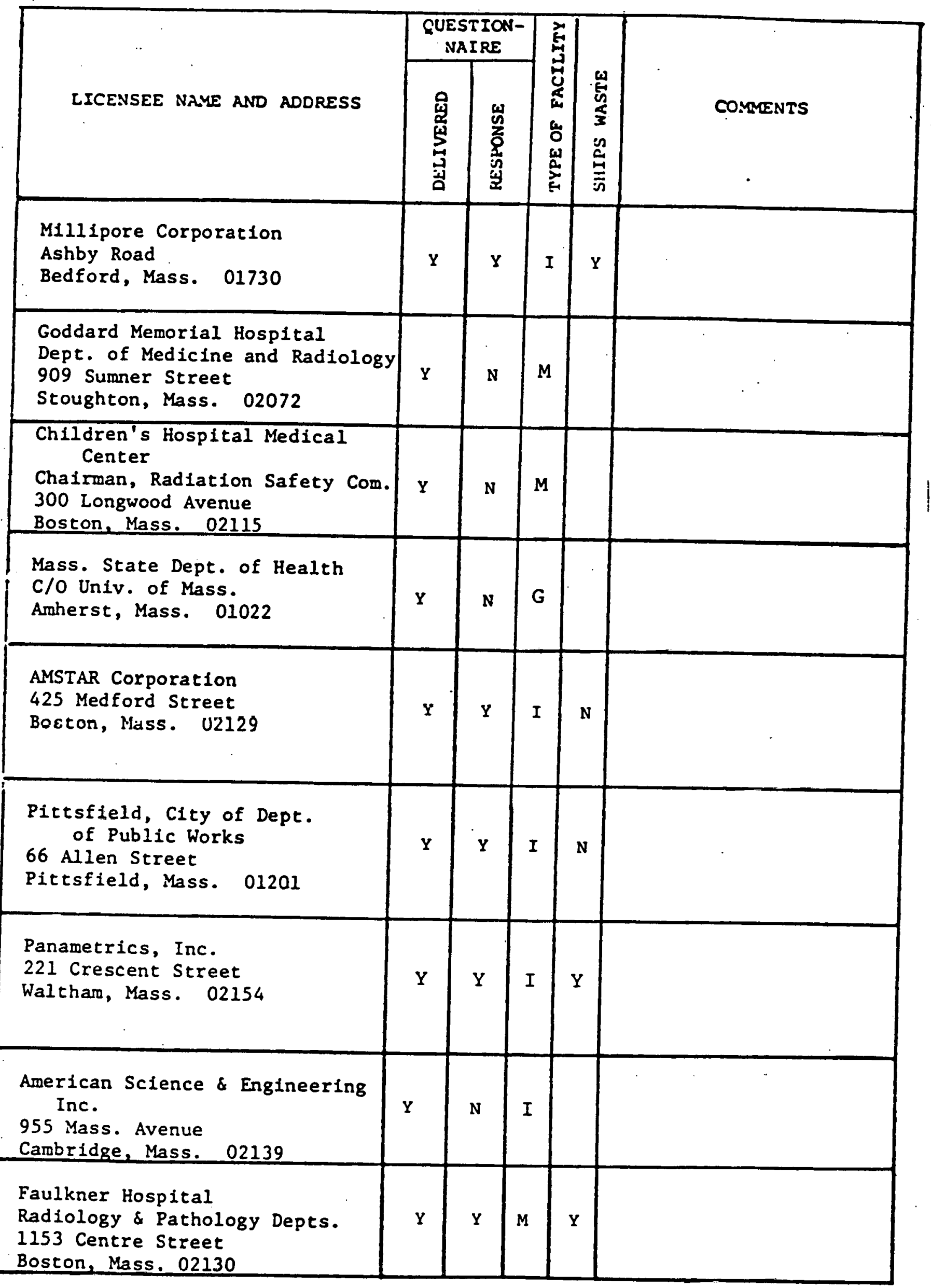




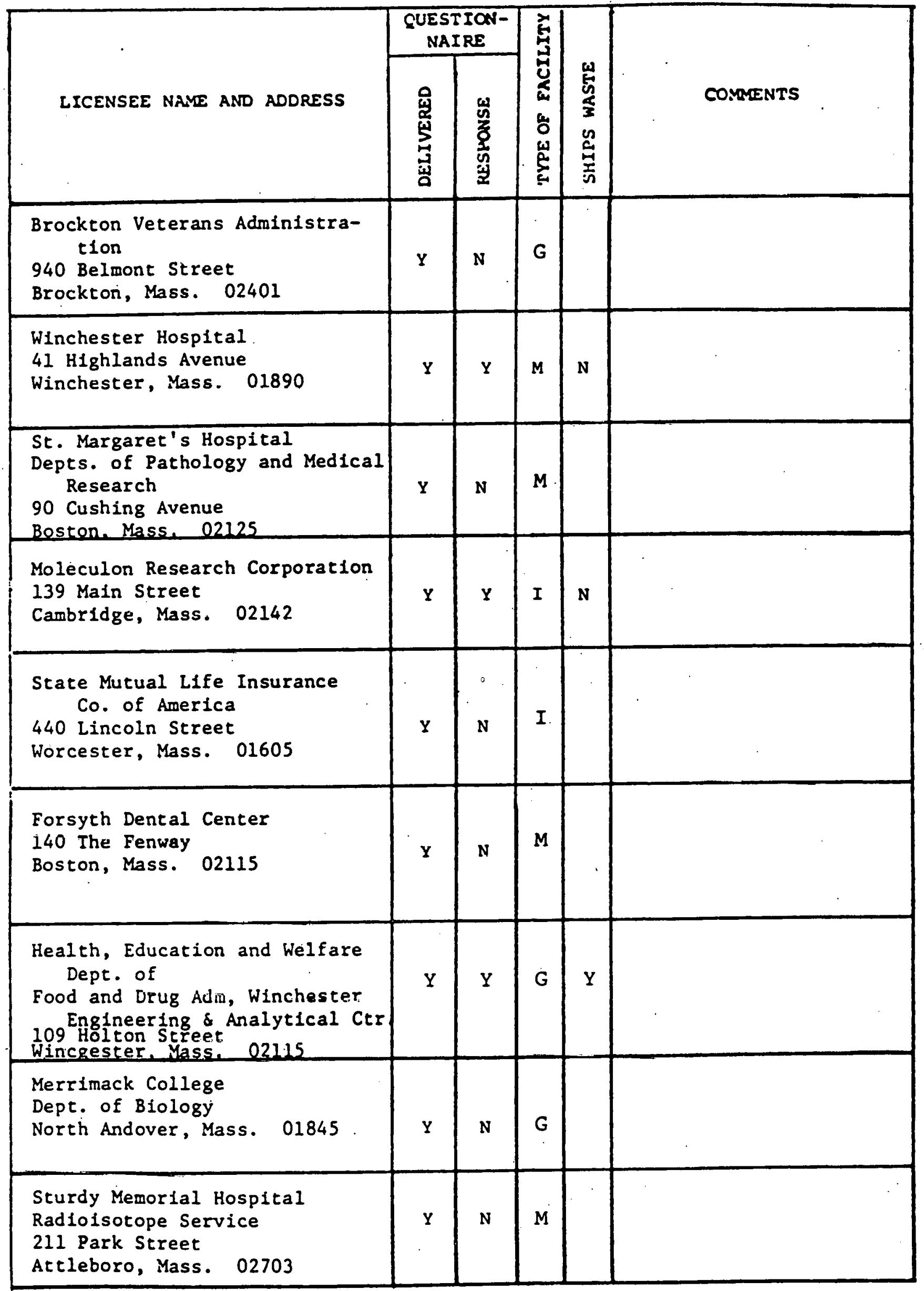




\begin{tabular}{|c|c|c|c|c|c|}
\hline & $\begin{array}{l}\text { QUES } \\
\text { NA }\end{array}$ & $\begin{array}{l}\text { ION- } \\
\text { RE }\end{array}$ & 蛋 & & \\
\hline LICENSEE NAME AND ADDRESTS & 參 & 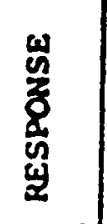 & 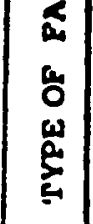 & 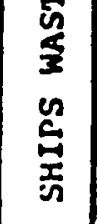 & COMMENTS \\
\hline $\begin{array}{l}\text { Ludlow Papers \& Packaging } \\
\text { Cummings Street } \\
\text { Ware, Mass. } 01082\end{array}$ & $\mathbf{Y}$ & 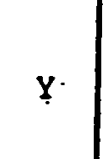 & I & $\mathbf{N}$ & \\
\hline $\begin{array}{l}\text { Framingham Union Hospital } \\
25 \text { Evergreen Street } \\
\text { Framingham, Mass. } 01701\end{array}$ & $\mathbf{Y}$ & $\mathbf{N}$ & M & & \\
\hline $\begin{array}{l}\text { Union Hospital } \\
\text { Dept. of Pathology. } \\
500 \text { Lynnfield Street } \\
\text { Lynn, Mass. } 01904\end{array}$ & $\mathbf{y}$ & $Y$ & $M$ & $\mathbf{N}$ & \\
\hline $\begin{array}{l}\text { Whidden Memorial Hospital } \\
103 \text { Garland Street } \\
\text { Everett, Mass. } 02149\end{array}$ & $\mathbf{Y}$ & $\mathbf{Y}$ & M & $\mathbf{N}$ & \\
\hline $\begin{array}{l}\text { Borden Chemical Co. (The) } \\
1 \text { Clark Street } \\
\text { North Andover, Mass. } 01845\end{array}$ & $\mathbf{Y}$ & $Y$ & $M$ & $\mathrm{~N}$ & \\
\hline $\begin{array}{l}\text { Mason Research Institute } \\
\text { 57 Union Street } \\
\text { Worcester, Mass. } 01608\end{array}$ & $Y$ & $Y$ & $M$ & $Y$ & . \\
\hline $\begin{array}{l}\text { Collaborative Research, Inc. } \\
1365 \text { Main Street } \\
\text { Waltham, Mass. } 02154\end{array}$ & $\mathbf{Y}$ & $\mathrm{N}$ & $I$ & & \\
\hline $\begin{array}{l}\text { P1 ymouth Rubber Co. } \\
104 \text { Revere Street } \\
\text { Canton, Mass. } 02021\end{array}$ & $\mathbf{Y}$ & $Y$ & I & $\mathrm{N}$ & \\
\hline $\begin{array}{l}\text { Gordon College and Divinity } \\
\text { School } \\
255 \text { Grapevine Road } \\
\text { Wenham, Mass. } 01984\end{array}$ & $Y$ & $Y$ & $E$ & $Y$ & \\
\hline
\end{tabular}




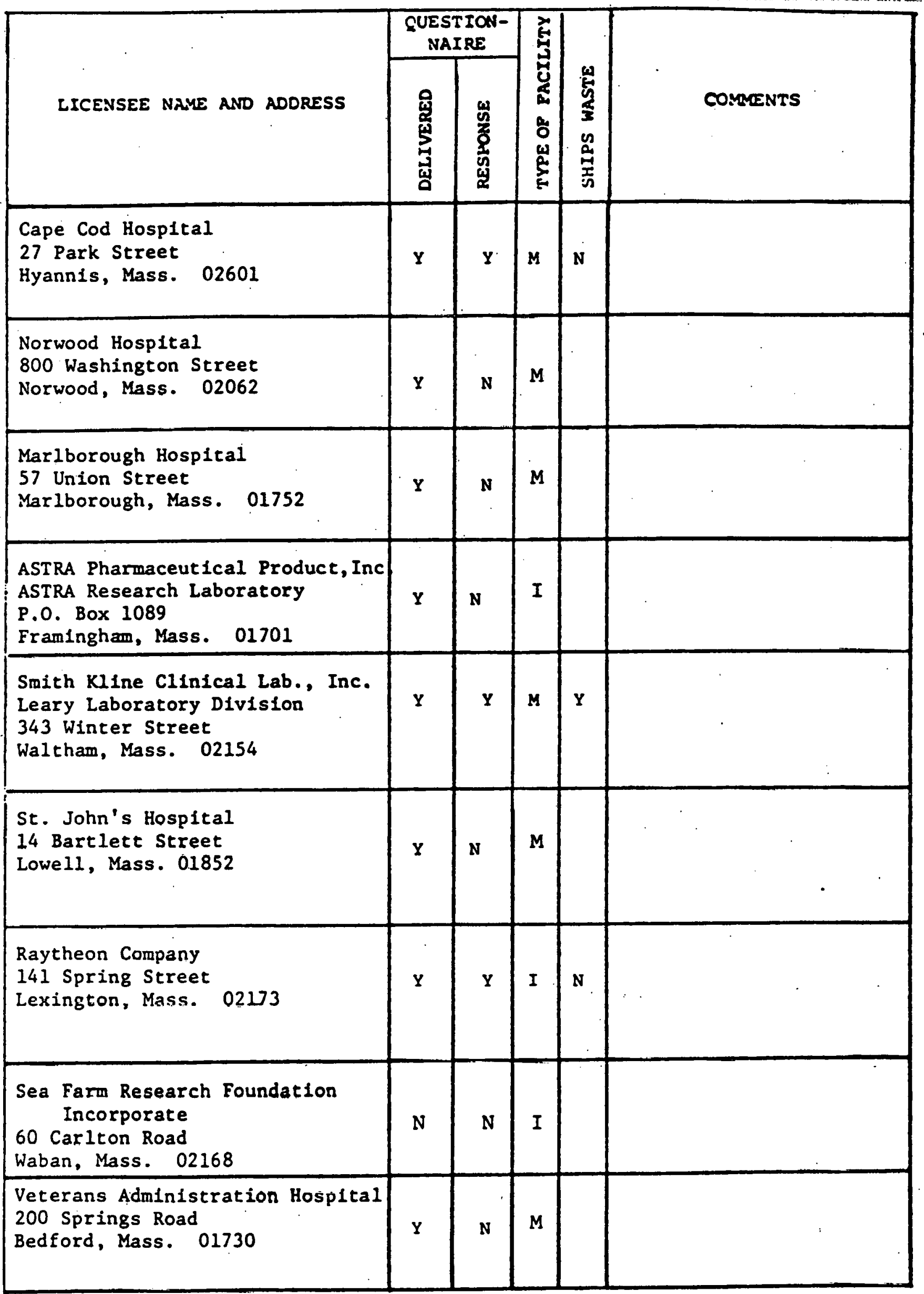




\begin{tabular}{|c|c|c|c|c|c|}
\hline$\therefore$ & $\begin{array}{l}\text { SUES } \\
\text { NA }\end{array}$ & $\begin{array}{l}\text { ION- } \\
R E\end{array}$ & 站 & & \\
\hline LICENSEE NAME AND ADDRESS & 善 & 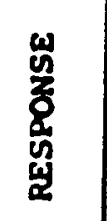 & 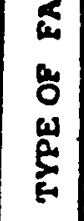 & $\begin{array}{l}\bar{y} \\
\frac{1}{3} \\
0 \\
0 \\
\frac{1}{2} \\
\frac{1}{3}\end{array}$ & COManents \\
\hline $\begin{array}{l}\text { Walter K1dde \& Co., Inc. } \\
\text { Fenwal Div. } \\
400 \text { Main Street } \\
\text { Ashland, Mass. } 01721\end{array}$ & $Y$ & $\mathbf{N}$ & I & & \\
\hline $\begin{array}{l}\text { Fairview Hospital } \\
24 \text { Lewis Street } \\
\text { Great Barrington, Mass. } 01230\end{array}$ & $Y$ & $\mathbf{Y}$ & M & $\mathbf{N}$ & \\
\hline $\begin{array}{l}\text { Dept. of the Army } \\
\text { Water Quality Lab. Corps of } \\
\text { Enginers } \\
\text { Barre Falls DAM, R.F.D. } \\
\text { Hubhardston.Mass O1452 }\end{array}$ & $Y$ & $\mathbf{Y}$ & G & $\mathrm{N}$ & \\
\hline $\begin{array}{l}\text { Nashoba Com. Hospital } \\
\text { Dept. of Nuclear Medicine } \\
200 \text { Groton Road } \\
\text { Ayer, Mass. } 01432\end{array}$ & $Y$ & $Y$ & $\mathbf{M}$ & $\mathbf{N}$ & \\
\hline $\begin{array}{l}\text { Glover Merorial Hospital } \\
\text { Needham, Mass. } 02192\end{array}$ & $\mathbf{y}$ & $\mathbf{Y}$ & $M$ & $\mathbf{N}$ & . \\
\hline $\begin{array}{l}\text { ION Track Instruments } \\
\text { l09 Terrace Hall Avenue } \\
\text { Burlington, Mass. } 01803\end{array}$ & $y$ & $\mathbf{N}$ & I & & \\
\hline $\begin{array}{l}\text { Radiology Associates of } \\
\text { Framingham, Inc. } \\
475 \text { Franklin Street } \\
\text { Framingham, Mass. } 01701\end{array}$ & $Y$ & $\mathbf{N}$ & $I$ & & \\
\hline $\begin{array}{l}\text { Central Hospital } \\
26 \text { Central Street } \\
\text { Somerville, Mass. } 02143\end{array}$ & $Y$ & $Y$ & M & $\mathrm{N}$ & \\
\hline $\begin{array}{l}\text { GTE Laboratories, Inc. } \\
40 \text { Sylvan Road } \\
\text { Waltham, Inc. } 02154\end{array}$ & $Y$ & $Y$ & I & $Y$ & \\
\hline
\end{tabular}




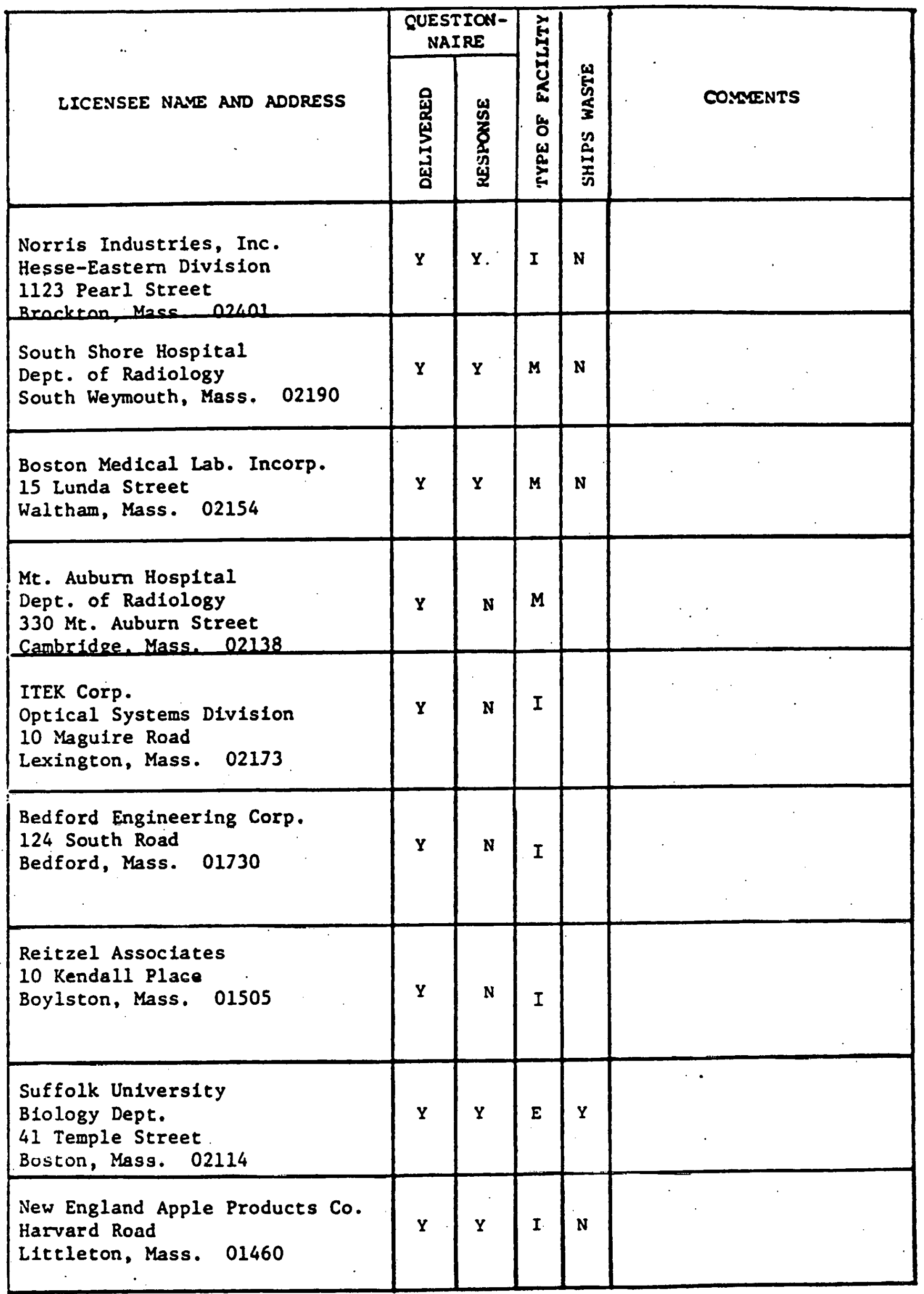




\begin{tabular}{|c|c|c|c|c|c|}
\hline \multirow{2}{*}{ LICENSEE NAME AND ADDRESS } & \multicolumn{2}{|c|}{$\begin{array}{l}\text { QUESTION- } \\
\text { NAIRE }\end{array}$} & \multirow{2}{*}{ 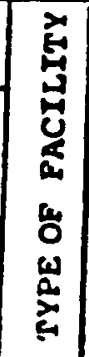 } & \multirow[b]{2}{*}{ 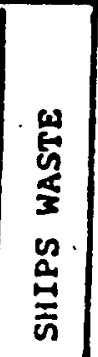 } & \multirow[b]{2}{*}{ COMENTS } \\
\hline & 昜 & 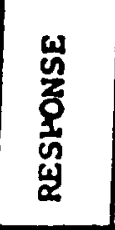 & & & \\
\hline $\begin{array}{l}\text { Springfield Technical Comm. } \\
\text { College } \\
1 \text { Armory Square } \\
\text { Sprinfield, Mass. } 01105\end{array}$ & $\mathbf{Y}$ & $\mathbf{N}$ & $\mathbf{E}$ & & \\
\hline $\begin{array}{l}\text { Addison Gilbert Hospital } \\
298 \text { Washington Street } \\
\text { Gloucester, Mass. } 01930\end{array}$ & $\mathbf{Y}$ & $y$ & M & $\mathbf{N}$ & \\
\hline $\begin{array}{l}\text { Serono Laboratories, Inc. } \\
\text { 11 Brooks Drive } \\
\text { Braintree, Mass. } 02184\end{array}$ & $\mathbf{Y}$ & $Y$ & I & $\mathbf{Y}$ & \\
\hline $\begin{array}{l}\text { Analog Devices Semiconductor } \\
829 \text { Woburn Street } \\
\text { Wilmington, Mass. } 01887\end{array}$ & $\mathbf{Y}$ & $Y$ & $I$ & N & \\
\hline $\begin{array}{l}\text { Galileo Electro-Optics Corp. } \\
\text { Galileo Park } \\
\text { Sturbridge, Mass. } 01518\end{array}$ & $y$ & $\mathbf{N}$ & I & 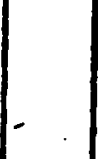 & \\
\hline $\begin{array}{l}\text { Marine Research, Inc. } \\
\text { 141 Falmoutn Heights Road } \\
\text { Falmouth, Mass. } 02540\end{array}$ & $\mathbf{Y}$ & $\mathbf{N}$ & I & & \\
\hline $\begin{array}{l}\text { RIA Products, Inc. } \\
411 \text { Waverly Oaks Road, Box } 914 \\
\text { Waltham, Mass. 02154 }\end{array}$ & $Y$ & $\mathbf{x}$ & M & $Y$ & \\
\hline $\begin{array}{l}\text { Spire Corp. } \\
\text { Nuclear Science Dept. } \\
\text { Patriots Park } \\
\text { Bedford, Mass. } 01730 \\
\end{array}$ & $\mathbf{Y}$ & $\mathbf{N}$ & I & & \\
\hline $\begin{array}{l}\text { Noble Hospital } \\
115 \text { West Silver street } \\
\text { Westfield, Mass. } 01085\end{array}$ & $Y$ & $y$ & $M$ & $\mathbf{N}$ & \\
\hline
\end{tabular}


APPENDIX B: "LOW-LEVEL RADIOACTIVE WASTE MANAGEMENT IN MASSACAUSETTS," a Report to the Governor of Massachusetts by the Massachusetts Advisory Council on Radiation Protection, November, 1980. 
LOW LEVEL RADIOACTIVE INASTE MANAGEMENT IN MASSACHUSETTS

\author{
Report to the Governor of Massachusetts \\ by the \\ Massachusetts Advisory Council on Radiation Protection
}

November, 1980 


\title{
LOW LEVEL RADIOACTIVE WASTE MANAGEMENT IN MASSACHUSETTS
}

\author{
Report to the Governor of Massachusetts \\ by the \\ Massachusetts Advisory Council on Radiation Protection
}

November, 1980

SUMMARY

Low Level Waste (LLW), i.e. waste containing small amounts of radioactivity, is gerierated in the Comonwealth of Massachusetts from medicine and medical research, university and industrial research, and industry including nuclear power generation. In the very near future, this waste, now shipped at great expense, to three distant, but reluctant states, will have to be disposed of either regionally or within the Comonwealth. The amount of radioactivity is low and the volume is far smaller than the volume of other hazardous waste and of solid waste. The management of LLW, therefore, can be much simpler and less costly than the management of other waste forms. In addition, the management of LLW can be conducted in an economical and proper manner that protects the envizonment and the health and safety of the public.

To continue the benefits that accrue to the Commonwealth (employment and taxes, advances in medicine and research) it is necessary to be able to continue the disposal of LLW. Because the volume of LLW generated in Massachusetts is the eighth largest in the nation and represents $10-50 \%$ of ald that is generated in New England, it is recommended that a LLW management program be initiated immediately within the Commonwealth. Eight additional recommendations are given in this report to set forth the conditions for implementing the program and to assure a satisfactory LLW management program. In particular, it is recomended that an education program be instituted to give everyone the opportunity to understand the LLW problem and the proper management of LLil and, hence, to suppcrt, constructively, the implementation of this necessary program.

This report consists of a short accourt of the problem and the set of recommendations. Details of the technical considerations in LLW management are contained in six appendices. 
TARLE OF CONTENTS

Simmery

Tatle of Soltents

Menbershi $i^{\prime}$, Idyiscry' Coureci an Radiation Protection

Membership: 2u hoc Comities on Lov Leve? Histe

1. Introduction

2. Statement oi tihe Probler.

j. Recommendations

Appendices

App. A. Naste Clinssification

tpp. B. Marnizuds and Handling of Low tevil raste

Bi. Volume a:ki Radicacti: $=$ y

B2. Criteria for Pacliaginz

App. C. Transpcrt and Processing of Low Level Waste

C1. Transport

C2. Processing

ApF. C. Kecycling and Reclamiion for $b$ iune Ruduction. 15

typ. E. Siting Cursiderations for Processing ar:c Burial it

Apr. F. The Need for Education $\quad 20$

:1. Perspe:tive co Radiction and Pa:-iactivity :0

62. Implementation of Eucation Pavian 2it

3. Alsijenes 24

F4. Approach to Fuitic Ejuration 24

F5. Edusarion Relarive to iacilit: Siting 25 
MEMBERSHIP

ADVISORY COUNCIL ON RADIATION PROTECTION

Constantine J. Maletskos, Chairman

Gloucester, Massachusetts

Frank Archibald

Department of Labor and Industries

Manson Benedict

Massachusetts Institute of Technology

Paul Cahill

Civil Defense Agency

Edward Hanley

Executive Office of Administration and Finance

John Marchant

Division of Personnel Administration

James R. Nichols

Nichols and Pratt
Gerald S. Parker

Department of Public Health

Laurence Robbins*

Massachusetts General Hospital

Patric Scavotto

West Roxbury, Massachusetts

Carlisle Smith

Department of Public Safety

Shields Warren *

New England Deaconess Hospital

* Deceased, 1980 


\section{MEMBERJHIF}

म̇a ficc Committee n:! Llw Level Wasto

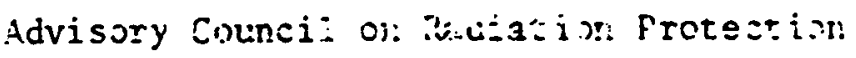

Conszartine j. Ma:etsiosos, Chairman

Glolicester, hassachusets

Murray M. Bclton, Jr.

Yassachusetts Instituse of Techno:ogy

Rotert is. H!a!lise:

oeperinen: of Public Healti:

Charles B. Killian

Sew Englanc: Nuclear Corporatior:

Puier S. Litt!ejitld

Vankee Atomic Eiectric Company
Franii $X$. Massé

Е. ․ Mussé sesociates. Ino.

Eesz: 1 S. Earker

Deparinent of Public Hea!th

Jacob Shapi: $=0$

Harvarc untivas: ey

Jin:s 0 . Stelis:=?

Exesurive Oyilica of Enviromentai iffairs 


\section{INTRODUCTION}

Extensive use of radioactive materials in the Commonwealth over the past 35 years has provided enployment and taxes and has led to advances in medicine and research. Currently, an estimated 5000 persons, employed in hospitals, universities and industry, are directly involved with the use of radionuclides.

As an example, in order for a hospital to be accredited it must have a formal nuclear medicine program. At least 30 percent of the people who enter hospitals benefit directly from a wide variety of radiopharmaceuticals or devices using radionuclides for diagnosis or treatment. Nearly all patients benefit indirectly from basic medical research in which radionuclides play an important role.

Similarly, radionuclides are used in many fields of research in universities and in industrial research centers providing a variety of benefits to society. As examples, these benefits include studies on the absorption of food in the nutrition field, on the flow of waters in the civil enginnering field, on the function of cells in the blology field, on the reduction of friction in the mechanical engineering field, and on improved components in the electrical engineering field.

In the normal life processes, all societies produce waste, from the production and use of food, transportation, energy, and other goods and serrices. Waste includes human waste (sewerage), solid waste (municipai and industrial), and hazardous waste (toxic chemicals and metals). The magritude of the waste disposal problem is indicated by the volumes generated in the last two elasses. In Massachusetss, an estimated 500,000,000 cubic feet of solld waste and $5,000,000$ cubic feet of hazardous waste are zenerated each year.

In similar fashion, all uses of radionuclides, including the production of electricity with nuclear power, lead to some waste that must be disposed of in a safe manner. The radioactive waste discussed in this report contains small amounts of radioactivity and is called low level waste (LLiv). The volume of LLW currently generated in Massachusetts is estimated to be 170,000 cublc feet per year, about $3 \%$ of the volume of hazardous waste, $0.03 \%$ of soiic waste. Procedures for transporting and disposing of this LLW safely are well known. 
These proseiures can ba inglemented within the Comsunivealth without subjectir:g fine gencral public, inciuding those rearest the disposal cperations, to radition of any significanes compared with natimal radiation to which we ara $\therefore 1$ expustj.

This report describes and discusses tive ilw prohlen fa:ilig viasachuserts. Th: repor! also presents the acti.jn that the Ceswcrisealth must take to assure the proper hancijng lif LWW within its ocrders and, hence, to assure the continueci jenerits that derive from the lise if raciionucliues. The next section addresses ife rature of the problem and the need fcr action, while the third jection sets Enst? the recomenciations to initiute anc ins:in:te a LiW program.

This short revort is follcwos by a stries of appendicis that descrice,

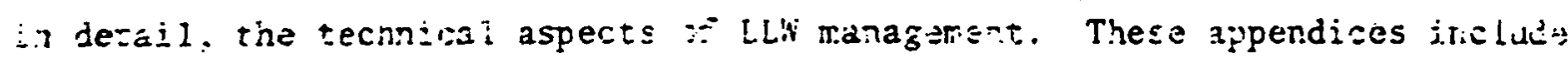
information on wazie ziassifiration; the magnitide and handiung of the wasta, s:ireria for paskiging, transpcrt srd processing; recycling and resiamaticr; and siting considerations for waste disposal facilities. The last apperdix, of sievial inporcance, discusses the need for ar education program to descaibe the razure of the problen. and to gifla a re:speitive to ali interssted parties on :2c'i issues as the raticactivioy invoived, thie zoneideraciuns for sicing a tacilizy, and the health ard other henefits obtained fron the use of radionusicies.

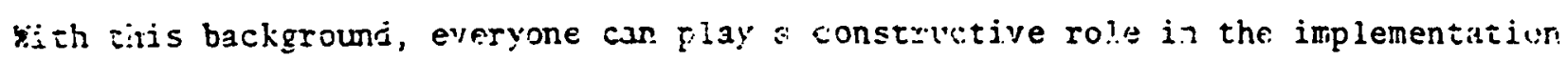
of a LLi ranagerent progran in the comorwealtin as soon as possible. 


\section{STATEMENT OF THE PROBLEM}

The temporary closings of the LLW disposal sites recently in the states of South Carolina, Nevada and Washington have dramatically pointed out the serious consequences that can affect the continued use of radionuclides in medicine, research, and industry. The reopenings of these sites, under considerably more stringent requirements and controls, emphasizes the probability that these three states will no longer continue to act as the sole receivers of LLW for the United States. It is quite clear now, as it has not been before, that all the states, individually or regionally, must participate in and contribute to the solution of LLW disposal.

LLW is in many respects similar to municipal wastes - consisting largely of paper, glassware, scrap materials and some solvents - except that it is contaminated with small amounts of radioactivity. Because the volume is small by comparison and the concentration of radioactivity is low (on average, not much different from radioactivity concentrations occurring naturally, including those in the human body) the difficulty associated with the disposal of LLW is not much greater than that of the proper handing and disposal of murjipal wastes.

The disposal of LLiN has always been under regulatory control. Regulations developed by the U. S. Atomic Energy Commission have been continued and improved by its successor agencies, the Energy Research and Development Agency, the Department of Energy, and the Vuclear Regulatory Commission as well as by the Environmental Protection Agency and the Massachusetts Department of Public Healih. These regulations require that ald users of radioactive materials be trained to follow prescribed rules for disposal of LLW. Adherence to these rules is monitored by the Nuclear Regulatory Comission and the Department of Transportation and by the states with LLW burial sites. These regulations, with proper inspection and enforcement, should ensure the safe operation of LLW disposal facilities and burial sires.

It is important to consider the economic impact of the development of local or regional disposal sizes. The cost of the disposal of LLW is currently absorbed as part of normal operations involving fadioactive naterial. This cost is increasing 
rapicly primariiy becalise of the spiraing sosts of fuel and the long distances requirec for trasportation and because of imreasorably escalating buriai fees. Thus, she cost of disposal wojic. be significantly reduceil with snoreer shippiag instances, and the savings cculc be upplied to the establisinent of local or regicoal disposai saculities. In zdutition to maintairing manageable djspesa? cests, finds ario jees and the accomanying creation of jobs ruild acerus te sre host consmity as important eroromie benetits.

baste n:aragenent is the prccess by whi:h waste is randlec froin its ganezarion to its fieni disposal. Tise several steps irvclved in this process 2ac: (1) appropriate choice of production $0:$ laboratory operations to produce je:s waste voiuse, (2) recycling, j.f possible, (j) radioarive decsy where practical, vatil waste pazerias is no icnger racioactive, (4) meciaricai volume reduction, and (3) Frthe: volume Feluction by jhrsi=al or shemical means, ert finally, i 6 ; zopez dispcsal of resious by burial requising techicically sound frocedures ilat invclve waste ferms ompatible with the cinaracisistics of the zioser sits. Criteria for choosing sitos, in turn, nust consider gcol zricai, gecgraphica!, enviromental, demcgriphis, and economic factors.

The sclution to the problem, :herefore, is to improve LLr: managenent ir.d to establish and oferate orocessing facllities with land birral uagaisy for disfosal. neary. The 47 redirining stites have a linitod griat feriul to jeraunstrate that hay will not expect the present three states to be the ning site:; for Lli disposal, and that, in fact. they are ready to assime responsirility for their owr wastes or share in a regional progran. Thus, the real solurion to tilis protilem rust include $a$ definite ard enlightente unilerstirding by ill

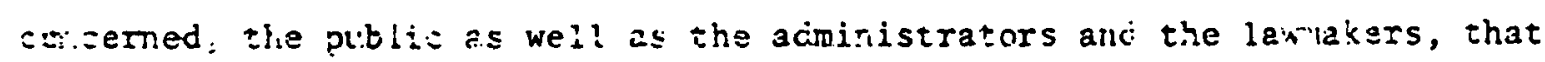
se gust take care of the wastes generates in the Comnorwalth iy properiy maraing ard disposing of them witrin our own gecgraphicol arei.

The Nivisory Council on Radiation Protection has decmed the subiect of LW disposal to be of prinary corcern for the Comnenwealth oi lyssachuset.s,

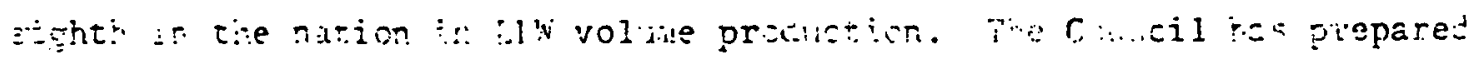

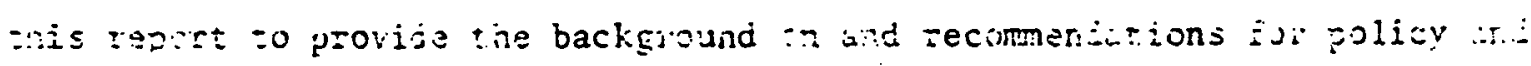

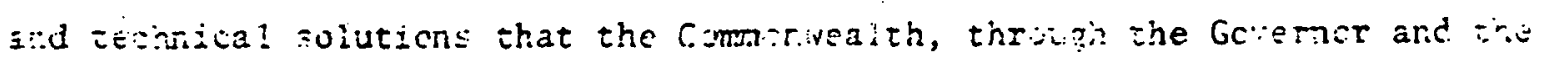
Legisiazure, might use to leve op and impiement a plali for ILW management. For the nctra! corizization of all those operations that use radioacive meterials,

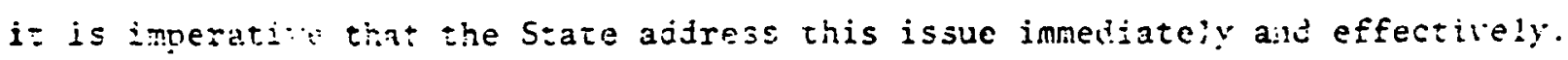




\section{RECOMMENDATIONS}

The Advisory Council believes that the LLil problem is solvable and that it is important for the Commonwealth of Massachusetis to start on the solution immediately.

There may well be advantages for zegional participation in which several states share costs, facilities and sites. However advantageous, the legal considerations are complex and Congressional action will be required for the states to enter into contracts that protect each others rights. Because resolution of the legal problems and enactment of Congressional legislation will take a few years, immediate action by Massachusetts to solve its own problem is the best course to follow. Should regional legislation be enacted, Massachusetts can enter into appropriate regional agreements in an advantageous and strong bargaining postion.

The LLW problem of llassachusetts is well-defined: the generators are known by license; the nature, volume, and radioactivity of the waste are known; the techniques for safely processing and disposing the waste are known; and the regulations are on record. The hazardous waste problem, on the other hand, is just beginning to be addressed in Massachusetts with the passage of the hazardous waste legislation. Eventually, it nav be advantageous to combine the two waste forms. However, at this time, it would be a disservice to the eitizens of the Commonwealth to tie the two types of waste together and, hence, delay action on LLW disposal.

When possible, the Commonwealth should take advantage of financial and techrical assistance offered by several federal agencies.

The specific recomendations of the Council to the Commonwealth are as follows:

1. Fncourage the immediate initiation of a program for low level waste management within the state.

2. Require that site selestion and facility development and operations be conducted in a thorough manner to protect the health and safety of the public and so protecs the entronment, to accord with applicable regulations. 
3. Irstitute an education progran. to give perspictive to the publi: mi the contributions to society of the services and froducts that produce iski, and or tihe practical and safe ineans of Li.l' dispusa:.

4. Eucourage anc supjort the managenent af LLW disposal by organizationr qua:ified froin the stancpois:s of expertise, eccnonsss, and long term staivility, and require firar.cial responsicility for atrent poerations is L.it .uanagement.

5. Ser up a mechanism for an escrow tiund, to be supporit: by the income if oferaicon, for fotentiai post-cicstre contingericies.

6. Require that generators be firancially responsible : of problens arising fron iriproper packaging and aciiderts.

$?$ Encouragc valine reduction tecinioues.

8. Set up a zeview body, consistigg of qualified expe: and of memicers of the pulliz, to audit the efsicition of the iull jisp-sal progray and to review pacpos:is on new techrijules for hardling LLi".

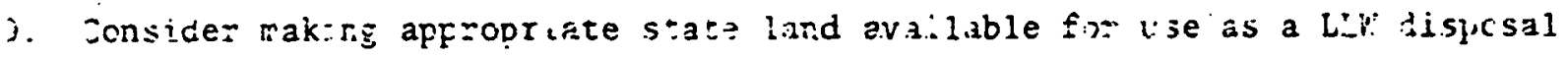
operations site.

As a final compert, the developmert of a pzogram of LiW disfossi wi:L have to include tine fublic, allewing it to play an intagrai roie in the pianning ani impiomentation. To be effective in this regard, lie pubits. sust ju informed atuut the benefits from the use ot radiacive naterials. the riced for froper disposal, lihe safesy of propur disposa: and the sorseniences

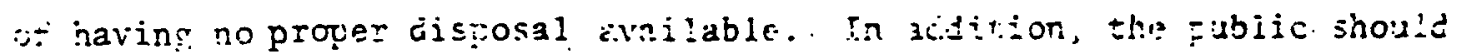

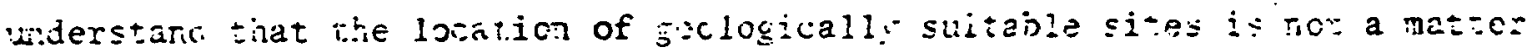

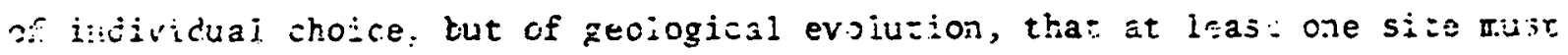
be cincsen, and tiblt support for the necessary zoning changes $u$ il be needed.

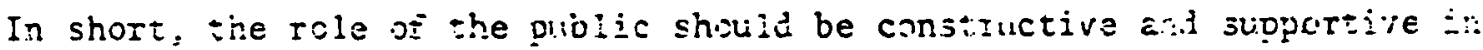
fincling ar acceptable soluzicin for LLh disoosa:. 


\section{APPENDICES}

\section{APPENDIX A. WASTE CLASSIFICATION}

For purposes of disposal, radioactive material is normally classified as Low Level Waste(LLW), Transuranic Waste (TRU) and High Level Waste (HLi).

All radioactive waste that does not fit into either the TRU or HLi categories is classified as LLW. Essentially all of the radioactive waste now generated in Massachusetts or in the Vew England region is LLW. This waste includes material from academic institutions, hospitals, radiopharmaceutical manufacturers, industry and nuclear power stations (excepting reactor spent fuel).

The Nuclear Regulatory Commission (NRC) has recently proposed (NRC,19796) further classification limits, within the LLW category, that would define waste acceptable for shallow land burial. This classification system is based on concentration limits that are related to the potential hazard of critical racionuclides. Naste not acceptable for shallow land burial would have to be disposed of by intermediate depth burial or some other method providing an equivalent degree of isolation.

Waste material containing quantities of radionuclides with atomic rumber greater than 92 (i.e.,plutonium, americium, etc.) in excess of 0.001 nicrocuriest per gram is oresently classified as transuranic waste. This TRU waste is eurzently stored in retrievable storage facilities pending ultimate disposal. The new classification system described above will include TRU waste and thus define the method of disposal to be used. Waste containing concentrations of transuranics or other radionuclides unacceptably high for shallow land burial results frcm spent reacror fuel reprocessing or weapons producion. High lovel waste consists of either the liquid or solid waste generated by the reprocessing of this fuel. The HLW proyram is being addressed by the federa: governgent.

'A curie is a unit of radioactivity equal to $37,000,000,000$ nuclear transformations per second. A microcurie is $1 / 1,000,000$ of a curie and is equal $203 i, 000$ nuclear transformations per second. 
AFPENDIX B. MAGNITUDE AND HANDL IN; OF LO: LWIEL WALTTE

81. Polune and Fadioacti:i:ty

Tae volume ard radioacivity cf Lifi inc the iistubution of users is giver in tabie 1. The intecration presented in this rable is axen fron sho

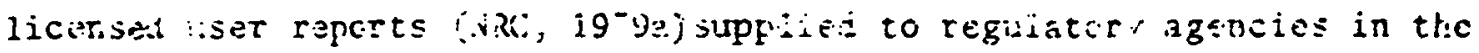

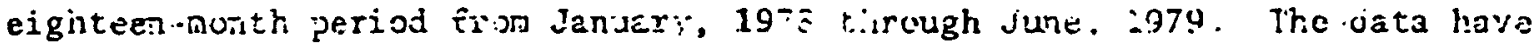

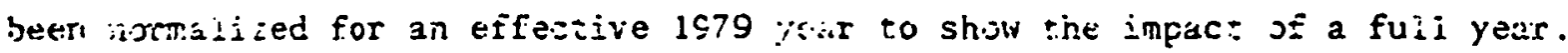
There ara approximately 410 U. S. Nuciear. Fegliatory icenses: registered in

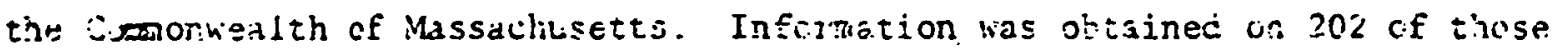
regjstered. The processors ere divided int: the foll lijing categories: comercial jower, industriaj, acadenic arc bosyital. LiN tran universt

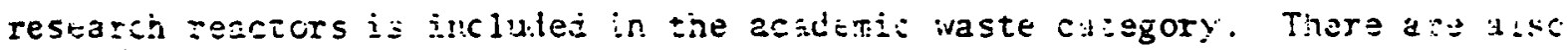

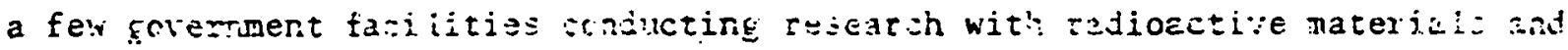
thes rave been included in the industrial zategory. The remaning cori licenstes, whose insomatior, vas not available for this report, are corsidised

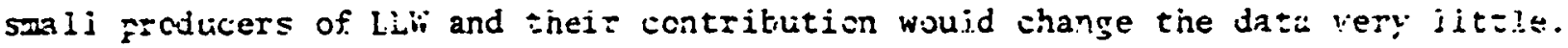

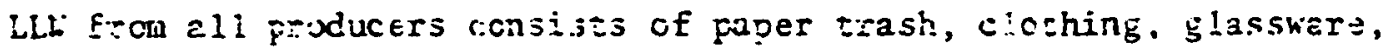
ecuipment, chemicais, tilters, s.Jlidified waste, scintillation vials, animel carcaises and othe: =untaminated materials. A single :cintainer can have radicaptive zatorials ransing fror a sillionith of a curie te klindreds of curia.s of

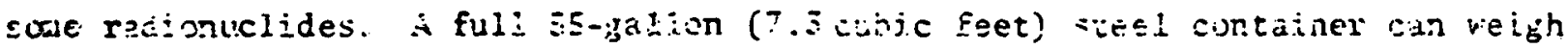
enuwher: $:=0 \mathrm{~m} 50$ is inc pouncis.

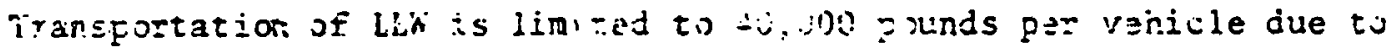

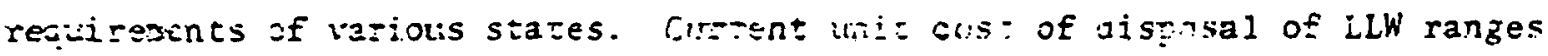

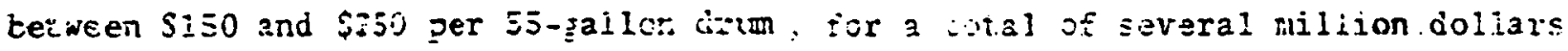

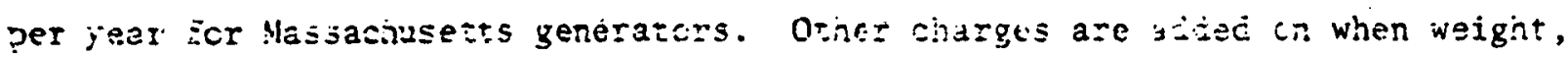
quantity of radioantivity and radiatroa jeveis exceci speci ijes linits.

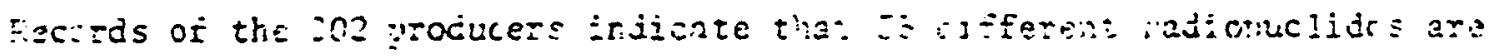

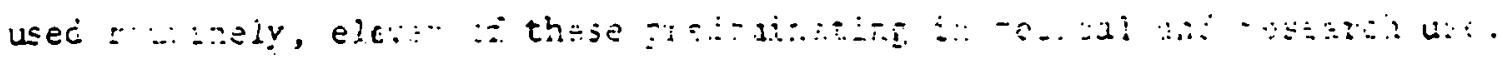

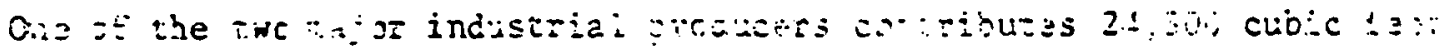

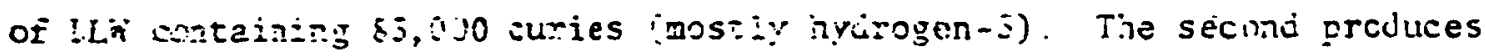
50,400 =ioic jeet containing jo :utias of jepletej unanium. 
Table 1. Low Level Radioactive Waste Shipped from Massachusetts ${ }^{2}$

Category

Licenses

Reviewed

Licenses above

That Report

No Waste is

Produced

Large Volume ${ }^{b}$

- Producers

- Cubic Feet

- Curies ${ }^{c}$
Power Industria

2

$-\quad 37$

77

24

11

48

96

99

202

Sma11 Volume.

- Producers

$\begin{array}{cr}2 & 2 \\ 50,000 & 84,000 \\ 1,000^{d} & 8 j, 000\end{array}$

2

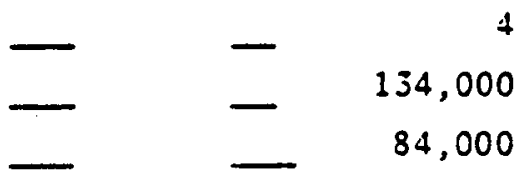

- Cubic Feet

38

13

51

102

- Cubic Feet

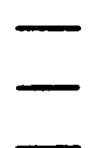

7,400

8,100

19,000

34,500

- Curies

81

44

18

143

\section{GRAND TOTAL}

Volume: 168,500 cubic feet; radioacivity: 84,145 curies

a Data have been adjusted for operations over one vear.

$b$ This category includes those who produce more than 5000 cubil feet/year and 50 curies/vear.

$c^{\prime}$ A curie is a unit of radioactivity equal to $37,000,000,000$ nucleat iransformations per second.

d Quantity depends on sinutdowns and core changes. 
About jug of the producers zepcrt that no LLW is sent to jurial sites. These produce:s hold their radionicilces for 10 to 15 half iives and dispose the decayed frodlits though sonventions: conmercial methods.

The site of rie lew England LLH disfosal problew fanc tale includirg New York)is iajicated by the reportej roivmes of waste shiprace cron the naigrinoring states. Table 2 indicates ghat tie Massachuset: thlil voluxe is

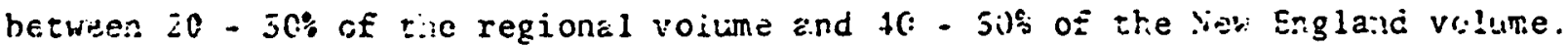
Theis percentages shouid be slifficjent incentive for Miassachusetts to take $a$

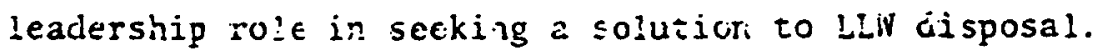

B2. Triteria FC: Paixaging

Ail low-levei waste accertad for aisfosai by land btiłal is packaged

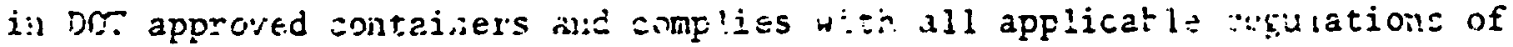

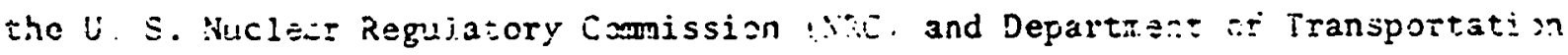
(1)Oii) and of the Conn:crivealtl: of lassichus etes through the egartment of Piblic Healeh.

The waste form must be packaged tn aryest fires thrcugt. friction. absaption of moisture or spontaneous chemical chay.... and, if ty sin : chance ignited. wust not buxn so $y$ igorousiy and persisza:. as to create a tiazard dyring handling, storage, and disposal. In acj:zir:, Lił cortaining purhegenic, istictious or ather biviogical ma:erial ri:-- ie treated, prive :o packaging, to minimize the potential haza:d of this motz: al

The foilowing ciasses of LLit are identified uncer the iriteria of the existing :arial sices: 1. dry soijJs, 2. absorbet liquies, j. liquid scint llaicior viais, 4. animal esriasses, 5. sisses, ard 6. resins 5or eash cilass there are specific jackising requirements.

Sore changes in psckaying eriteria would be advisable if volume recistion by incineration were adof tod as piat of a lecsl disposal cperation. Orie cit

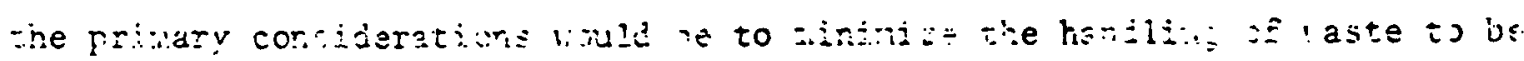

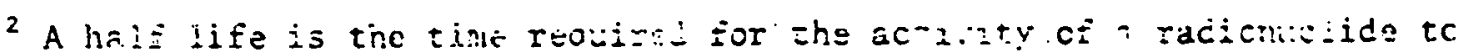
decay to one half the initial va bue. 
Table 2. Low Level Waste Volumes Shipped from Massachusetts and from States Veighboring Massachusetts ${ }^{a}$

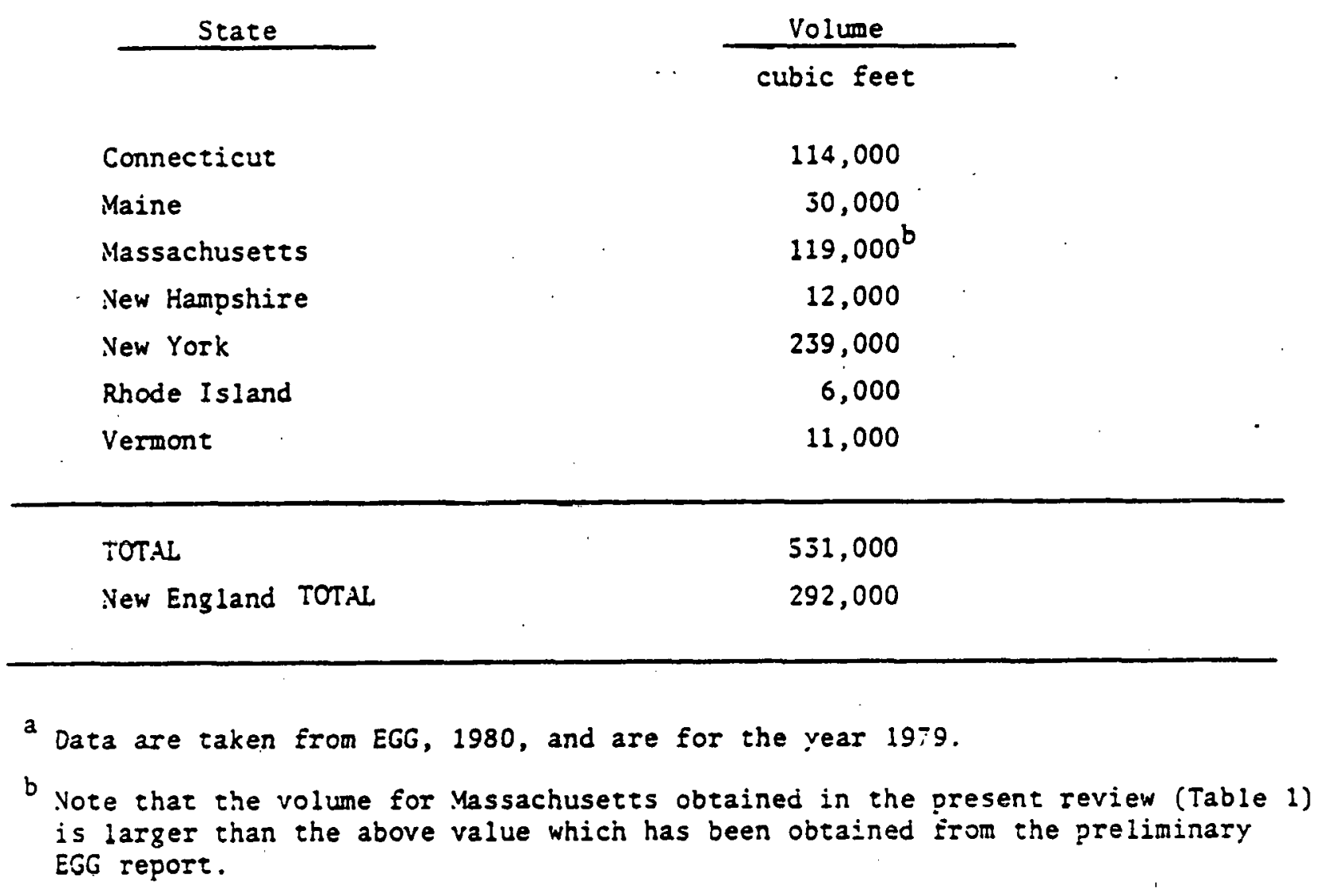


incrrerated so as to ninimize bot: the siusaticn expcsure to ppeiating persennej and the poiential for redicast: : contaminarion. it icuid be desardbis, theretc:e, to package comblistible LLyi in: sonbustibie packaging, sized sil:ab!:

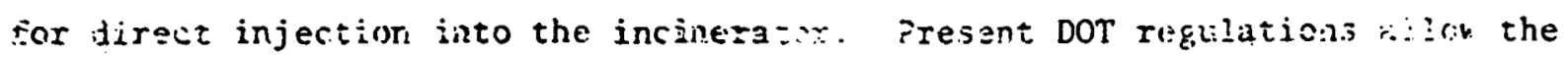

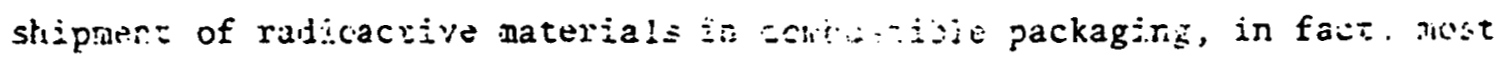

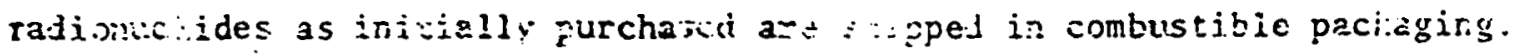


APPENDIX C. TRANSPORT AND PROCESSING OF LOW LEVEL INASTE

\section{C1. Transport}

Packaged low-level radioactive waste is transported from the Massachusetts "generator" to one of the three remaining LLW repositories in the U. S., where it is buried under the full control of a permanent curator. Such transportation is by truck, usually in full "exclusive-use". trailer loads. The majority of LLW generated in Massachusetts is currently shipped to the Hanford site in Richland, Washington, or to Barnwell, South Carolina. Low-volume generators of LLW usually contract with a middle-man or "broker", who collects the packaged waste from several such generators, warehousing as necessary until full trailer-loads are accumulated. A significant factor in the recent cost escalation in this entire process is associated with the distant locations for burial. Those involved in this business over the past few years recall shipping to West Valley, New York; to Sheffield, Illinois; to Morehead, Kentucky; to Barnwel1, South Carolina; to Beatty, Nevada; and now to Richland, Washington.

The location of an appropriate site for operation of a facility and for burial in Massachusetts should take into consideration the transport routes that would be involved in getting the LLW to the site. While the transportation of LLW does not pose a significant hazard, proper routing, ineluding the wse of ali oi the Commonwealth's major highways, should minimize unnecessary transport through communities.

\section{C2. Processing}

The bulk of the material included in the LLW volume is suitable for incineration in terms of both its combustbble nature and of its radioactivity content. The cost of initiating an appropriate incineration progran would be high for the Individual generator, when the requirements of the federal, state and local air pollution control laws are factored into the equipmen: design. The rechnology is available, however, to incinerate this material safely and properly on a large scale, if the combustible Lliv from many generators could be efficiently pooled for this purpose. In fact, proven incineration techniques are available that result in a 5-10\% residue bound in impervious materials such as glass or iron slag, yielding not only greatly 
recluced velumes, but mih less lexciable ijsposai forms. Compared with the current enst of [ew i:soosaj, a cocperacive central taciliry or commercial operation with these ralume zacuction cafabilities ruid be economicalis reasihle in this state.

Such a facility coulc̈ zeeraze in sis of severa: ways. (1j It anl process (incinerate, sompact) ail waste irom varicus jenerators, ts radice rolumes 23 auch as possiole for ustimite burial at me of the existing ittes. (2) Is could receive only combustibie ijil from various generaters to incinerate

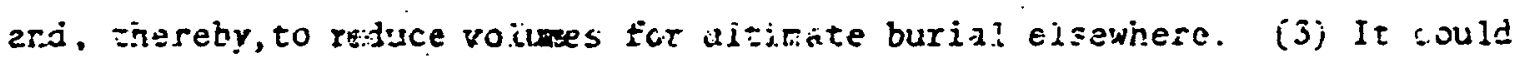
rsieive all waste as in ivo. I abote, anj frocess and bury it on site afier obsaifing appropiate licenses axe lecrances. (1) It coijd operate i. sombired fashion, whereby an inc:codse with capacity and capability ta iancile

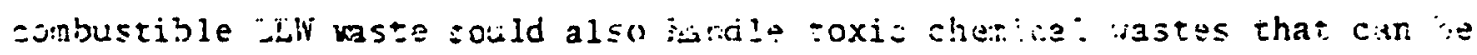
suitably zreacad by incineraticr, with the litimat-b:a-ial of the residuc $x$ be arranged eiseviere or on site. (5) ic cclid be ganarijy an incinezatior. site, designed large erough to handie a l combustibie LLW and all tcixic chenical wasie as weil as 211 micinal waste f:on the comicnity or region in which it $i \equiv$ lecated, witl: Irrangemerts for the ulitimate br:ial of the radibictive and tux.s: residues elsowhere or $2 \pi$ site, 1 th the sita netss the appropriate reciuizements.

The Fifth mede would be the ileal and most :terive approash to take.

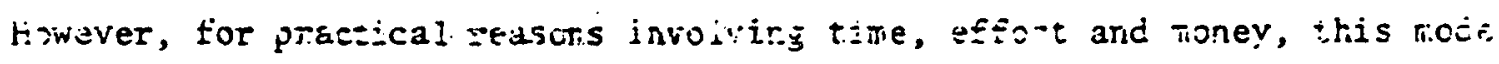

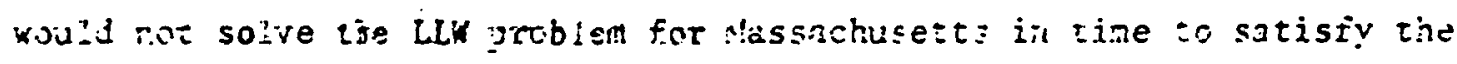
derands sor ea:ly zeilef by the three stides now acs:ainin wiste.

The ncs: pracicai soilion, therefore, is the shiod :ott, processing and buria: on the same site since sices geo:orizaly satisfactory for hajurjois

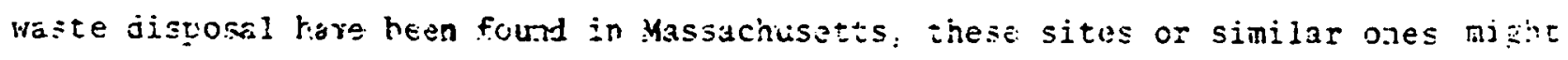
be ideouate :or ill disposai. Licensing for Lli jnaiseration is a relatively

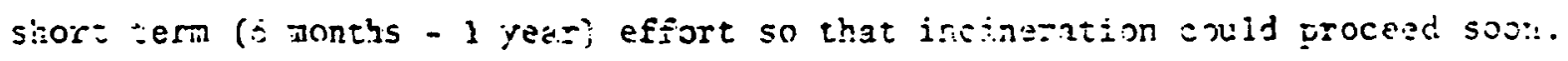

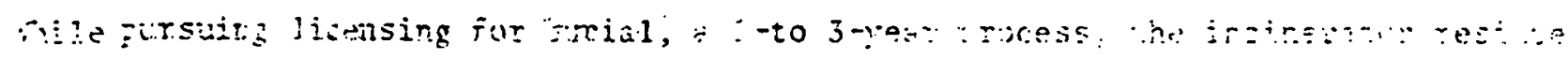

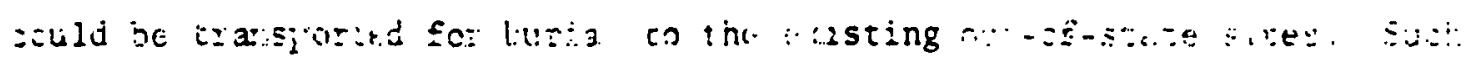

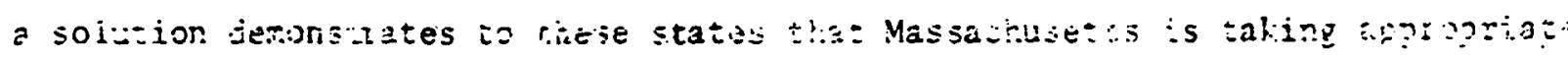
aztion and, at the sane time, is transporting and fequesting burial in: srala: rolumez of much less lea:hacle biste. 
APPENDIX O. RECYCLING AND RECLAMATION FOR VOLUNE REDUCTION

This section is included in this report to show that there are other potential means for reducing the quantity of LLW for disposal.

One alternate method includes recycling, i.e., the recovery and reprocessing for reuse of both the radioactive and non-radioactive components, or either one, of a radioactive material normally be scheduled for disposal. However, the separation of radionuclides from solutions, from complex compounds, or from fabrications that fail to meet quality assurance standards, is in an early stage of development. The incentive to investigate such separation processes is governed by economics, manpower, and new rechnology, none of which appear promising at this time.

The ability to remove radionuclides from materials varies according to the specific nuclide to be isolated, to its incorporation in particular compounds or materials, and to the quantity of the non-radicactive atoms of the same element present in the compound or naterial that will compete in the process because both the radioactive and non-radioactive atoms of an element behave chemically in the same manner. Current experience in chemical separation processes, such as distillation, evaporation, and column techniques, has resulted in up to 90 percent separation of the radioactive component. The degree of acceptance of the separated products depends on the purity and concentration of the radionuclide and on the degree of residual radioactive contamination of the component that is normally non-radioaciive.

Radionuclides can also be reclaimed from devices that contain them. For this purpose, the requirements of the process include dedicated space and equipment that might not be considered cost effective for a single or a few recovery operations. For example, to reclaim a quantisy of cesilm-137 from an obsolete sealed source requires the additional facilities of an enclosure with filtered exhaust ventilation ports to prevent release of ladioactivisy to the environment, remote tools to minimize radiation exposure of the workers, and chemicals to bring the radiocesium back to an accontable raw-material stace. In the process of isolating a large fraction of tive radiocesium, however, it is possible that the volume of contaminared waste to be disposed of could become larger than the small volume of the original waste source. 
Raycling aric reciunation processes ought to be investigated further with insreased effort and ingeniclis method. For the most effective volume recuctior, stict. jrocesses should ve ccrsidered for incorporation in the criginal procketion processes. 
APPENDIX E. SITING CONSIDERATIONS FOR PROCESSING AND BURIAL

The siting of a LLW disposal facility encompasses all steps from the development of site criteria to the licensing of the proposed facility. It includes the survey of prospective sites and their evaluations, leading to the selection of an acceptable location for the proposed facility. This section briefly describes the major considerations that must be addressed during this process.

The size of the site required for a low-level waste burial facility will depend on the volume of LLW in the state or in the region to be served, the desired length of time the facility will be operational and the desired exclusion area surzounding the active site. Typical sites may range from less than a hundred acres to several hundred acres, depending on how much land is already available for a buffer zone. The space requirements for a waste volume reduction/solidification facility would be much less, and the licensing effort for this type of processing plant would be significantiy less than that for a burial site whether on the same site or elsewhere. For this reason most of the discussion below pertains to the siting of waste burial facilities.

Until the present time, private industry has taken the initiative in seeking, selecting, licensing, and operating ne's comercial low-level waste disposal sites. The land on which these disposal facilities are located has been deeded to the Federal or State govermment. The private company, or operazor, is then responsible for assuring safety during use of the facility and the appropriate govermment agency is responsible for long-term care. The Interagency Review Group, however, has recently recomnended (IRG,1979) that the"Department of Energy (DOE) assume responsibility for developing and coordinating the needed national plan for LLW..." This IRG Report further states that future sites could be developed and operated by individual states or the the federal Government. If the facility is sited on state-owned land, title could be transferred to the sederal Government upon temination of the facility license. Responsibility for siting a new waste facility may thererore reside with eicher a private company or a government agency. The siting process itself however, will be relatively independent of whoever assures this resoonsibility. 
liurla of the groundwox in developing a methedolcgy for sitirg a Lit facility has been completed by the New England Regicral Commision (NERC:M,19:9) for tha purpose ct disposing hazardous wastrs. This study points out the importarce of alliwing :he maximu rumber of parties to participate in the decision-making pocess with tize urderlyjng asstmpica taat "sone fiza: Eiting

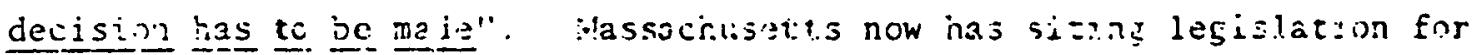

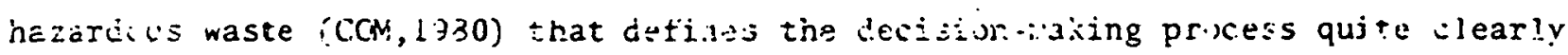
with iespest to combaity partir.ipation and tile proctiures to over:ome a pctential impasse. Many parts or this law apfly to the siting censideraticas ct Lin is ispesal.

The site mist be seiected to meet both sho:t-term, w. sperational. onsiderations, and lorg-term porturnance ibjecivivs. The proximity of

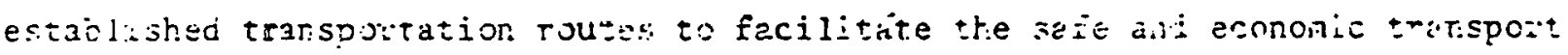

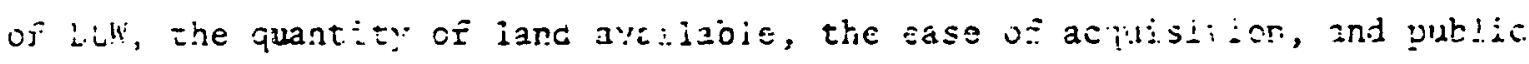
accepiance must al: je sonsidered as short-rarm conveniences. Fi.e lcrz-term performance objecti:e of the discosal Facility after cluslre is to assure what all $i$.W is contained within the facility fis the required lifetime of that waste.

Thi : long-torn performance objecti:e will jo met by j sita-srecific sysien: of ba:riers to LLW migration including tac specif act form if the buried waste, engineered barriers, natural shartacteristl:s of the :ite and its eiviror:s, and control over the use of the lik upon bich the sice is iosat $\leqslant d$.

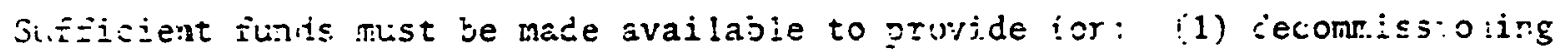
of tha cisuosal facility, Encluding disnanting surface s'ructures on the si:t, (2) stabilization: Ji the site ard the buried waste to precluce ongoing aitive nainterance, and (3) the proviston of survei lance and monitoring activities over a persat long encugh to shok that the jice scniorms to expectations.

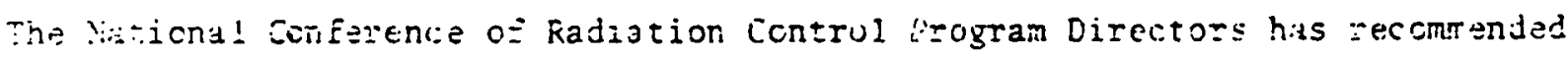

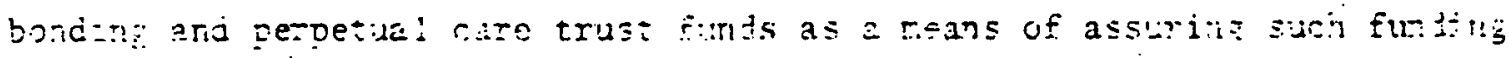

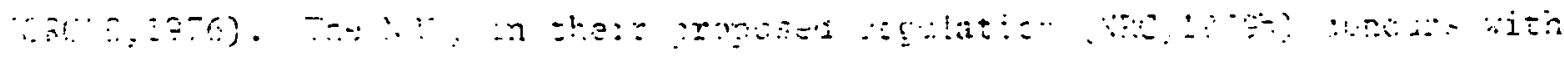

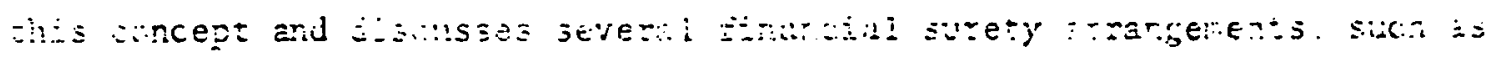

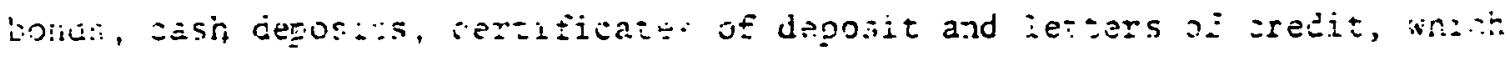

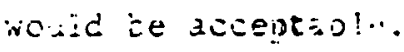


The characteristics of a proposed site must be investigated in sufficient scope and detail to assure that the objectives discussed above can be met, as well. as allowing a thorough evaluation of the site. These characteristics include, but are not limited to, demography, hydrology; geology and meteorology, and are discussed below:

a. For an adequately sized site, the facility should be sited in a relatively low population area and must be evaluated with respect to the present and future character and activities of the population in this area. This evaluation should also include the present and projected uses of the land, water and other natural resources of the area, and the proximity and type of transportation routes available for the shipment of LLW.

b. The site should be chosen so that the hydrogeologic environment of the area surrounding the disposal site will act to prevent or minimize the migration of waste through groundwater pathways. Site characteristics desirable in achieving this include low groundwater flow rates and soil properties which would adsorb the waste material, if it were released.

c. The facility should not be located in an area whare surface geologic processes such as erosion, landsliding or weathering could significantly enhance the hydrogeological transport of LLW from the site. The site should not be located near a capable fault such that the migration of waste could increase as a result of seismic activity.

d. The local meteorology aust be studied to assure that rain-water intrusion or wlnd erosion will not enhance the migration of waste to an unacceptable level. This study will also characterize local atmospineric dispersion to allow assessment of the off-site environmental impact from ai-borne releases.

The application for a LLW facility license will include a safery and environmentai report to meet the requirements of the NRC and the vational Environmental policy det (.NRC,19i9b). This report will contain 3 sull evaluation of the candidate sites and the rationale for choosing the proposed site. The results of the technical and environmental studies, as described above, will be documented in this license application, along with a complete description of the proposed method of operation. 
APPENDIX F. TKE NNEED KOR EDIJCATEON

Sucese of a LLi managenant frograx hriges on secui ill a juitable zeans of treatment and a site for dispusa?. Although wasto volume reduc:icn requirse iess spac: and $i \in s \equiv$ ling-tern moritozing than a sliallow lanifi: :

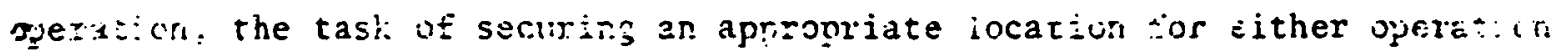

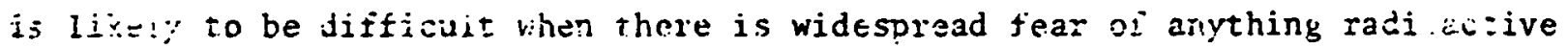
or nueitar. Any ilw maliagment ricoposal sholid iacude a pian that will help siange this misconcet.ticn, recueing fear througin betzer unjerstärding of sise issues. Thus, an eduration grograr. must be an integral pa:t of the cvera:l Frogran tor waste managenent.

:-. Rerstective on Radiation and Rusioactivity

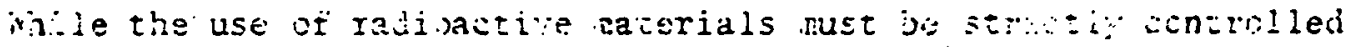

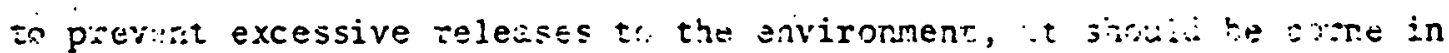

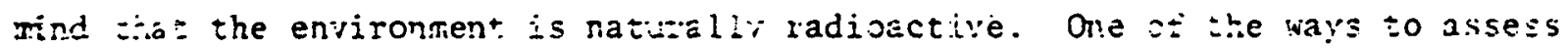
the signifizance of the disposal of LLW is to empare the "adioavtivity of LiW with this naturaliy occurring radioncivity. The latter radioactivity includes radionstivity in the air as adinective gases or par:isles, in th: ground,

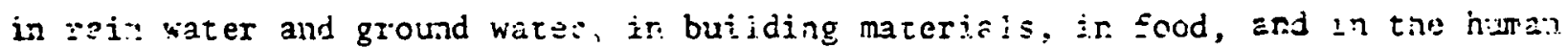

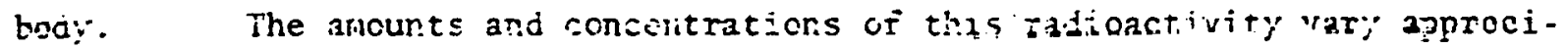
coly in ijfferen: locations. The raturally cosursing radionuclides also differ gzoatly in their i.oxicities, ari incluite some racisndelides that rark anong the most lazardous as weil as oiters that rarie anory the least lazarious.

Nizural radioastivity in the environiment c:izinates from u variery of

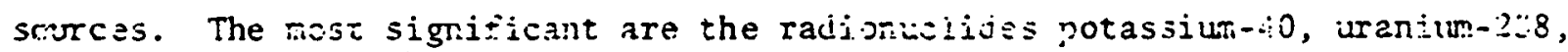
ant thoriut-23\%, produced when the siverse was crasted bilizons of years ag. an: ren:air in sigrificant guartities today because of their long haif lives (yeater than a billion years). When they decay, trey are follaked by ajaitioraj

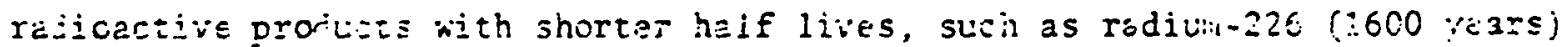

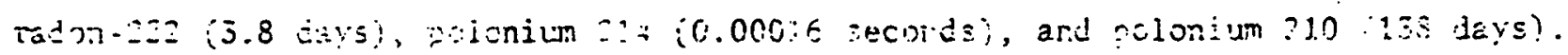

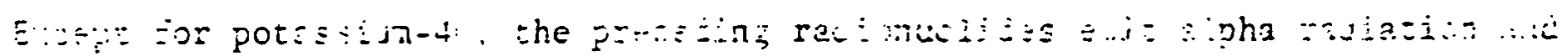
a.: o cissideres so be bisily toxac. 
A11. of the above radionuclides except one are solids and are distributed throughout the ground, from which they are taken up by vegetation or dissolved in ground water. One radioactive decay product, radon-222, is a noble gas. While it originates from the decay of the radium in the ground, it diffuses out of the ground and reaches significant concentrations in the atmosphere, particularly when the air is still. Radon also diffuses into homes, where the concentrations depend on the ventilation. The highest concentrations occur in homes that have little air exchange with the environment, such as homes in cold climates sealed to reduce heat losses. The decay of each radon atom is followed by 6 successive decays, producing radionuclides which emit alpha, beta and garma radiation. The decay products are found in the ground, food, and water, and form radioactive aerosols in the air which are breathed in and retained in the lungs.

Radionuclides are also generated continuously from the action of cosmic radiation on elements in the atmosphere. The most significant are carbon-14 and hydrogen-j (tritium). Both emit very low-energy beta particles and are among the least hazardous of radioactive materials. The radiation dose to each person from carbon-14 is $0.7 \mathrm{mrem}^{3} /$ year and from tritium, 0.001 mrem/year.

The cosmic radiation and the gamma radiation emitted by radioactive therials in the ground are responsible for large differences in radiation doses in different places. For example, at an 3 ltitude of $1.6 \mathrm{~km}$ ( $1 \mathrm{mile}$ ), the annual cosmic-ray dose of 45 mrem is greater by 17 mrem/year than that at sea level. Annual radiation doses in the U. S. (including both terrestrial and cosmic radiation) range in various locations from $32 \mathrm{mrem}$ to $197 \mathrm{mrem}$, a cotal difference of $165 \mathrm{mrem}$. Residencs of the city of Denver recoive a whole body dose of $125 \mathrm{mrem} /$ year compared to $65 \mathrm{mren} /$ year for inhabitants of the Atlantic and Gulf coastal states and 80 mrem/year for the majority of the U.S. population. Neutrons, not included in the above dose values, contribute ar additional annual $30 \mathrm{mrem}$ at $1.6 \mathrm{~km}$ and $6 \mathrm{mrem}$ at sea level.

3 The quantity of radiation dose that places all radiations on a common basis for assessing biological effects is called the dose equivalent. The init of the dose equivalent is a rem. 1 mrem $=1$ millirem $=1 / 1000 \mathrm{rem}$. 
There are also large dififererces in raliantivity ir the $a i r$, due primarjiy to the naturajly diciaring radisactivo gas acaci-222. Concentrations o: radon-222 in uutdoor air ranje from $20-1000$ pizocurjes ${ }^{4}$ /autis netar. The arresponding average dose rates to the luggs range fron $20 \mathrm{mren} /$ yea: to \$000 mrenijea:. Variaticus in radiun-320 sontert in the diet producis variatais

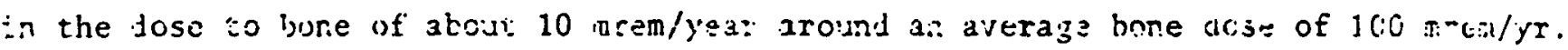

T:pocal levels of radionctivity in tle grource and in tae ait ar: given i.l Table $j$. These levels are quite ignitiont, and it is importi:at to note thir these radionucijdes are not encased in containers but are trulv accesjible to ground sater, ro fooc crcps, ard to the itnosyhere.

Despite the large differances in radiation levels, vary row people give any thought to naturs: radioactivity in jelecting a plase to wo:k or iive. There is no evicorce that these rariaticrs are sigrificant in afiecting the incidence of eancer ir other ciscases. In anj evert, thene is iittle one can do io contro: popliation exposures from these scurces.

Because of the natrral dibndance of radicactive materials, the disposal of sufiticiently srail quantities zi racioactive materizis in the $s$ round and via the air would not produce shonges that would be considered sisniticant: in view of the variations in tne sisting levels. The signest radizion ciose to which ary menter of the publis would be exposeri by $\equiv$ nroperly nandged LI.iN pregrain shovid net axcesd 5 mran vaar.

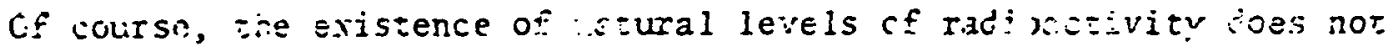
give $: \vdots z$ ense to puilute indiscrir.juteiy. The potentia! release of low laviz of radionctivity should be weighed sgainst the bertefits to suciety fror ine activities that preducec shis racicactivity. Finally, rieases should be reviewed for compliance dith the ald grincipie which recuirs shat the discharge of pollutants to ise envi=onent be kept As

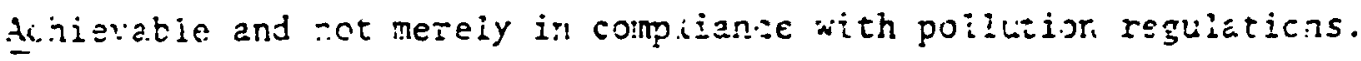

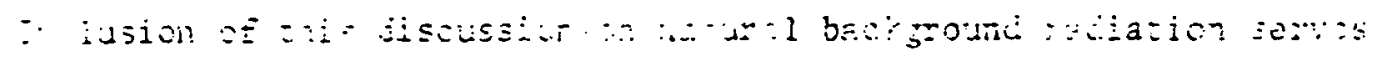

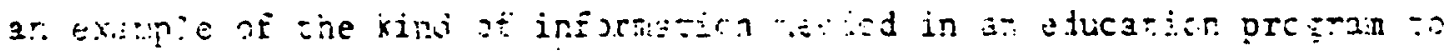
inprove wierstanding an the safe cispos? of LLit.

4 picseurie is 1/1,003,000,000,000 o a a curie and is equal to 0.037 nivelear trensfcrations per second. 


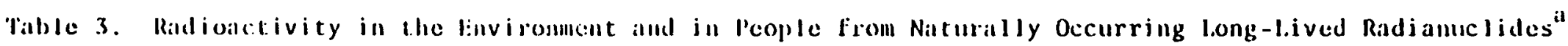

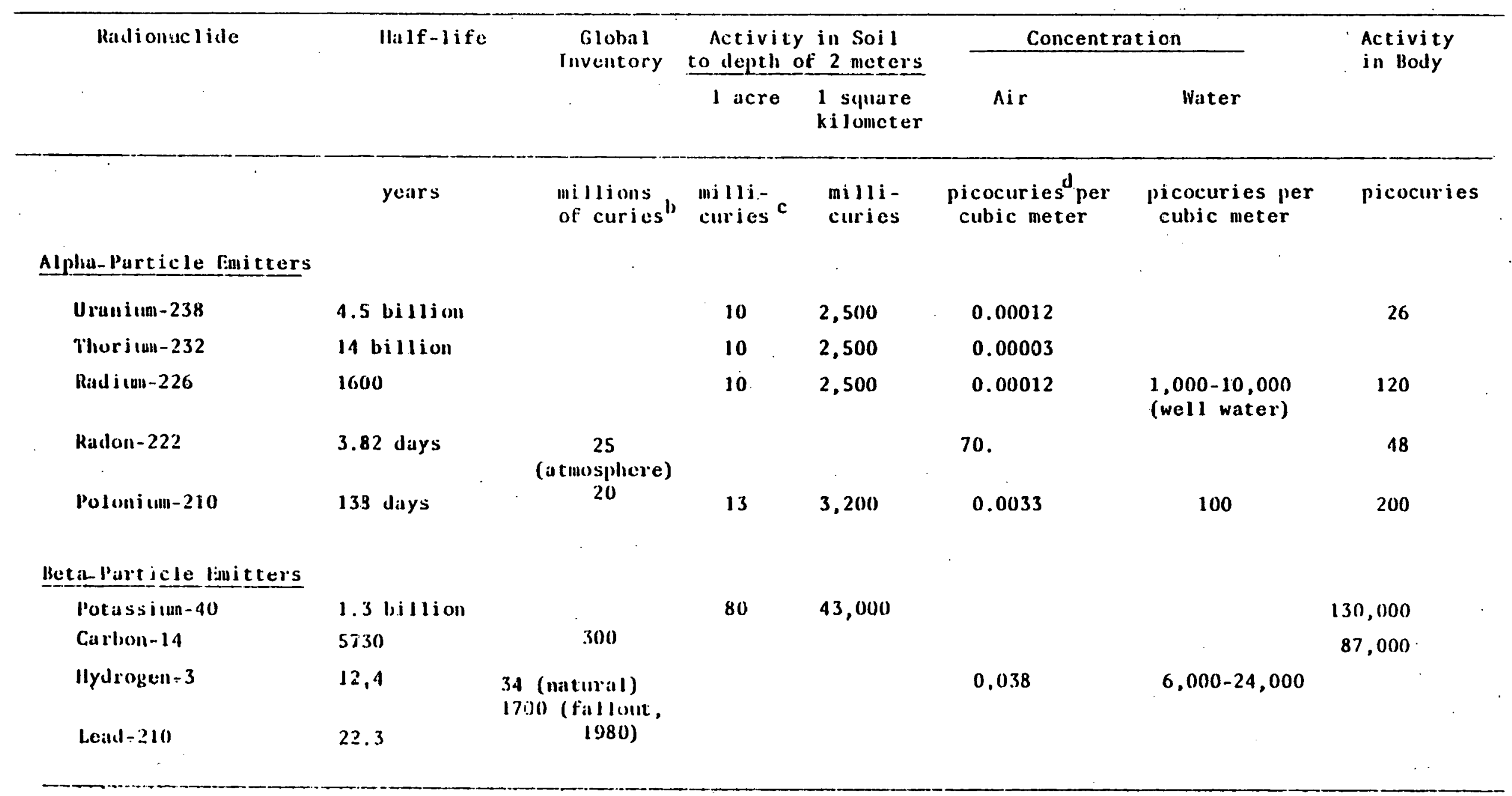

"Sources: UNSCl:AR (1977); NCRP (1975)

"Sec foutnote No. I for definition.

c A millicurie is $1 / 1000$ of a curie and is equal to $37,000,000$ nuclear transfornations per second.

d See foutnote No. a for definition. 
F2. Impiementaticr of Edilation Prograsi

A. sirgle state agency should be charget with design of the education program, coordination of infornation sncinglementation of the plan. Aitisusi: a consortium of liser: nigh provice educaituda services, the publis is rore

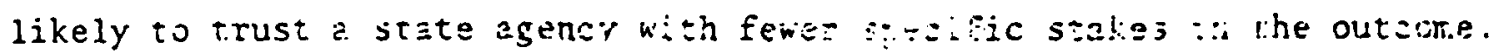
Funds for the pecgran. Hovever. night be: : $\%$ lited partididy or who: $\because y$

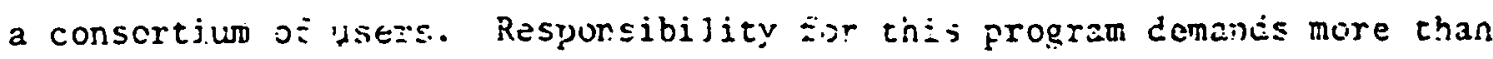
public relations skills; the ccorcinator st itc erfort muse be inciluded in techrical and poisy jiscussions to undersend the issues anci goals of the :ih managcinent propram.

F3. Audien:=

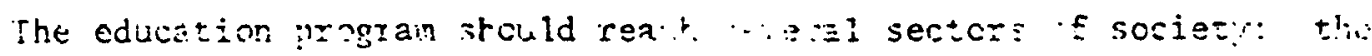

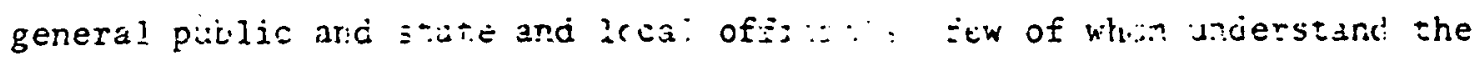

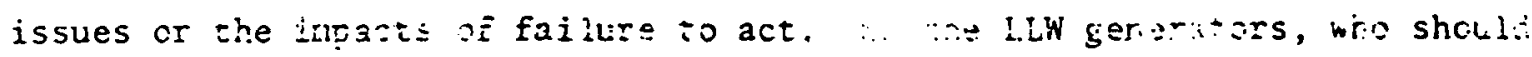

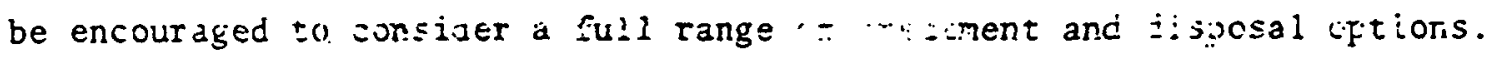

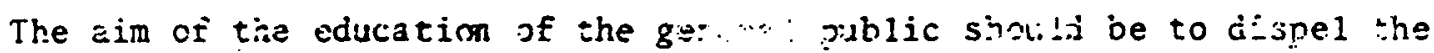
widely believed intis about anything late." "3jioacrive m nuclear and to provide a perspectils on suciet: : need $:$. : : ie its was:es proper ly. Most believe ali radicactive proucts so be er. : threarening to pliblic iralich

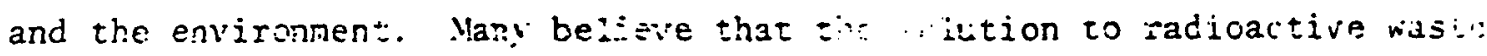

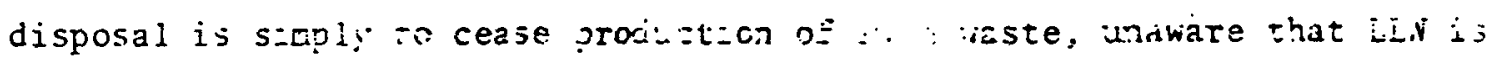

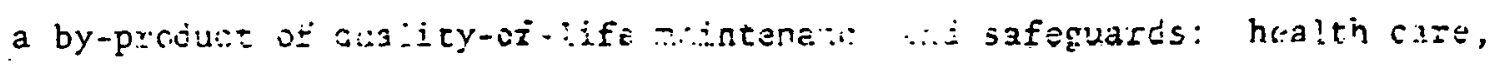

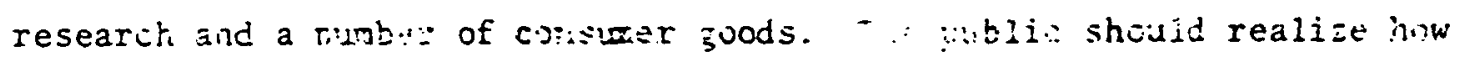
failure to assume tiss ie zponsibllity reuje

Lccii aid saze officiuls, wio wil! disinately rake de:isions about location and operazion, need to ise informet abolit the techroiogical sorndiness and the safety of processizg ant disposal iajiijtjes. irechanisms that roduce risks ard that of

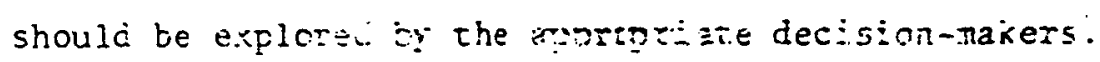

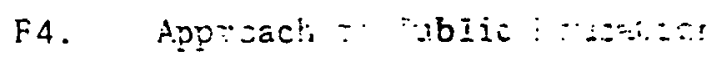

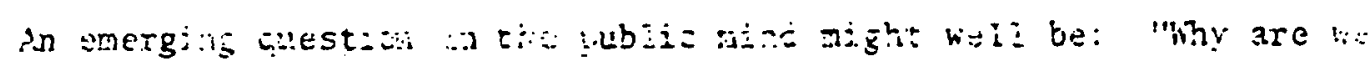

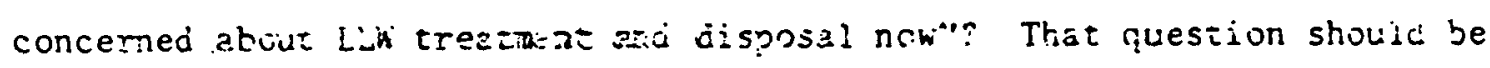


answered truthfully: present disposal sites are thousands of miles away and closing their services to out-of-state wastes. Massachusetts has not taken responsibility for its own waste in the past, and is now forced to do so.

Unfortunately, this awareness effort comes at the same time as an awareness effort for hazardous waste, and neither can wait for the other to be resolved. Although the two might be handled technologically as one, with comon issues and solutions, it may be that neither can bear the millstone of public fear of the other. Responsible officials in each area believe that management plans will be more readily implemented if the programs "go public" separately. Because the volume and variety of LLW is much less than that of hazardous chemical waste, the public aight be more receptive to dealing with LLW.

The primary goals of the public education program are (1) to assuage public fears about radioactivity and (2) to explain why in-state or regional treatment and disposal are necessary. Dissemination of information for the enlightenment of the public may include several routes, as follows:

a. Talent bank and speaker's bureal of advocates who are not known advocates of other nuclear uses: hospital personnel, researchers and other users as well as people who do not have a private stake in the issue. These advocates might appear before a variety of group meetings, offering a new perspective.

b. Workshop for media people to inform writers and comnentators of the spectrum of issues that surround LLW management.

c. Contact with environmental groups and trade organizations and their publications, offering information and articles about LLW generation and solutions to treatment and disposal problems.

d. Displays in publis places of consumer goods and health care uses that produce LLW.

\section{F5. Education Relative to Facility Siting}

Although a public education progran might successfilly convince people that an in-state or regional waste managment facility is needed, it does not counter the typlcal "But not in ry town" response. Any particular facility 
froposal is likeiy to face local opposition as communties weigh their stikss in the isside. Any specific fropced commisy perceives lncal cests from histing the facility (in the form of possible property vailu losses, fublic service costs, and the fear engendered by the proposali to be greater thian losal lenefitz. Totai banefits are dispersed frotighout the stan, senefiting al:

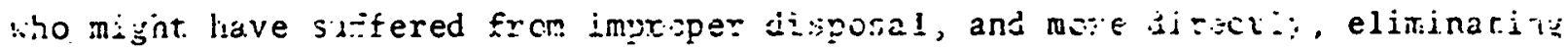
the cost ond incomenience of haling los sistances.

Aithcugh NR: (NRC,:2979t) specifies tha: cisposai fiililities shall be si:el oil land cwned by the federal or: state goiernent, and does nit specificaily roquire lcca: apfroval, iccal opposition to dity propcsal can ue expected, employing a variety of effective techniouses to dis:ourage sitte asjjgnnent. To effect a change in locai attitule, the balance of costs and bereitits to

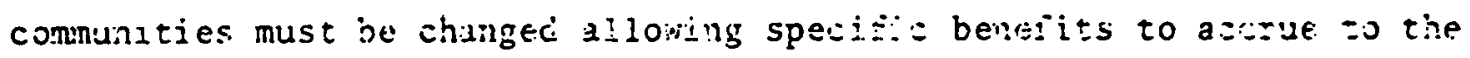
conmuni:y under consideration.

ireatest costs to a specifi: sonounify are $i$ in tine real arie procived risks inherent in any treatment or dispcsal facility proposal. Historically comnunities have teen offered litcle compersation for 3ssiming these risks. The proper approach :0 local sitirg lies in reducing tis sisks (whi:n cannot be reduced to 2erc) of hosting the fas 1 itty through presc: issi conditions and

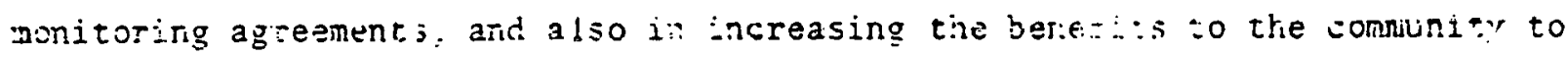
make the proposal atzzactive for id:a! zonsiteration.

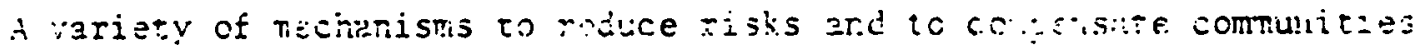

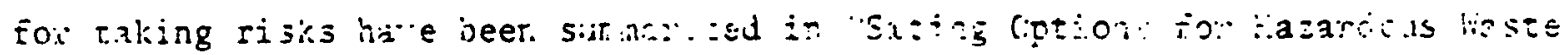

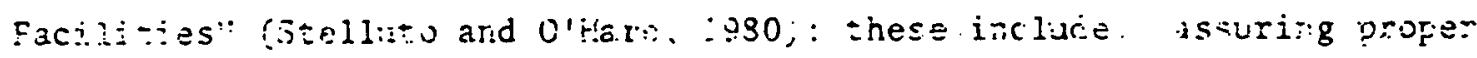

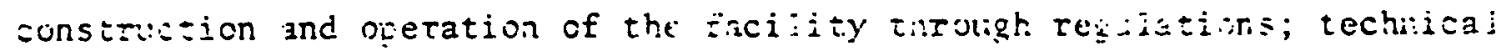

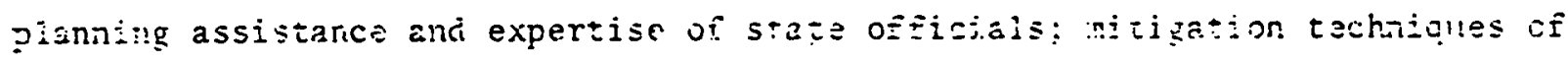

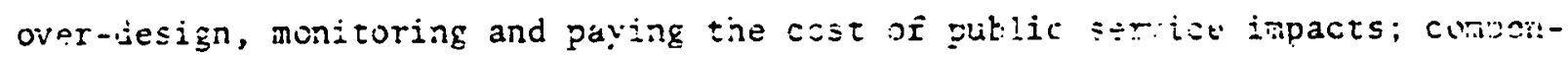
sation thrcigh rezzation faciliries, employnent frogr anc puytent in-lieu of taxes or handing sees: and insianse for heajth, aj: ait? ato oropery vajia losiss.

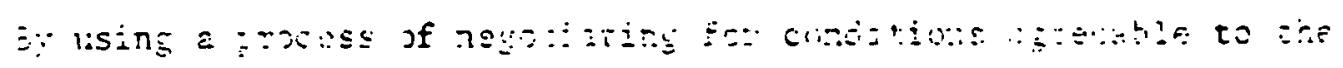

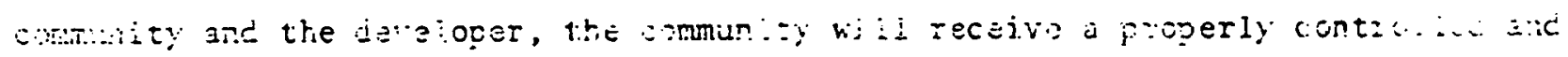
suger:isod faciity with aptopriate compensation for sosis incurred. In 


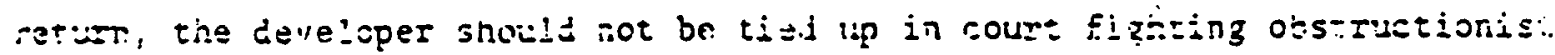
suiss, nor forcec to pay exurtitan: carfersaticr.

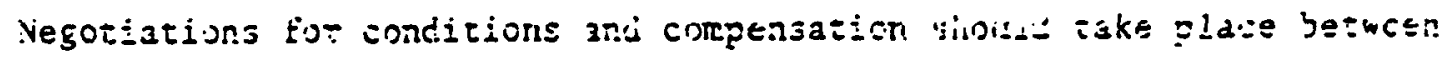

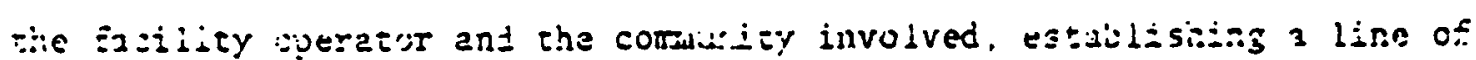

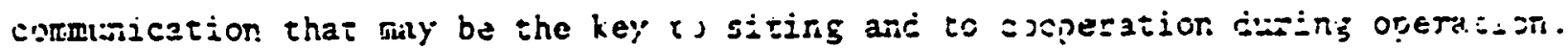

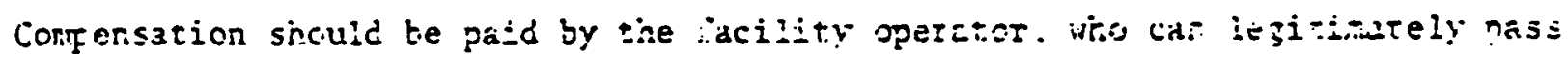
wost: along to the sonsunezs of tha waste generazors, the consun:tes jeiñ

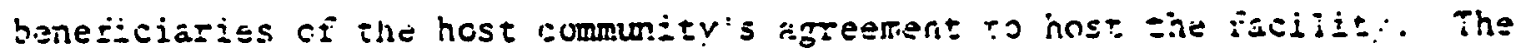

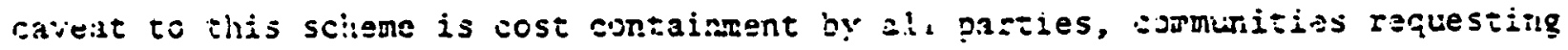

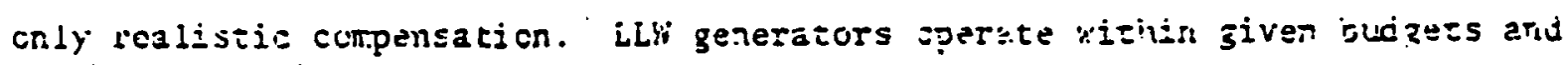

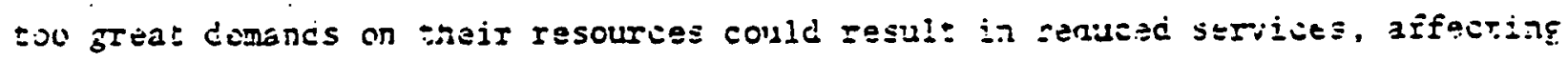
the production of consumer products. 
REFERINCES

CON (1980). Colmoriwealth of Massachusetts, Massachusetts Hazardous Waste

Facility Siting Act, Chapter 508 of the Act and Resolves of the

Massachusetts General Court (The State House, Boston, Massachusetts).

CRCPD (1976). Conference of Radiation Control Program Directors, Task Force

Report on Bonding and Perpetual Care of Licensed Nuclear Activities

(Conference of Radiation Control Program Directors, Little Rock, Arkansas).

EGG (1980). Edgerton, Germeshausen and Grier, Ine., Preliminary State-by-State

Assessment of Low-Level Radioactive Waste Shipped to Commercial Burial Grounds,

Report No. NUS-3440, prepared by NUS Corp. (EGGG Idaho, Inc., Idaho Falls, Idaho) .

IRC (1979). Interagency Review Group, Report to the President by the Inter-

Agency Review Croup on Nuclear Waste Management, Report No. TID29442

(National Technical Information Center, Springfield, Maryland).

NCRP (1975). National Council on Radiation Protection and Measurements, Natura!

Background Radiation in the United States, NCRP Report No. 45 (National

Council on Radiation Protection and Measurements, Washington, $D$ r.?

NERCOM (1979). New England Regional Commission, A Plan for Development of

Hazardous Waste Management Facilities in the New England Region, prepartel

under the llazardous Waste Management Program of the New England Regional

Comnission (Arthur D. Little, Inc., Cambridge, Massachusetts).

NRC (1979a). Nuclear Regulatory Commission, Packaging of Low-Level Radioactive

Waste for Transport and Burial, IE Bulletin No. 79-19 (describes information

to be submitted to NRC by individual license holders; reports also available

at the Massachusetts Department of Public Health) (Nuclear Regulatory

Commission, Washington, D.C.).

NRC (1979b). Nuclear Regulatory Comnission, 10CFR Part 61: Disposal of Low-

Level Radioactive Waste and Low-Activity Bulk Solid Waste, preliminary draft.

(Nuclear Regulatory Commission, liashington, D.C.) .

Stelluto, J. and O'llare, M. (1970). "Siting Options for Hazardous Waste Facilities".

Testimony presented to the Special Legislative Commission on Hazardous Waste

(Excutive Office of Environmental Affairs, Commonwealth of Massachusetts.

Boston, Massachusetts).

UNSCEAR (1977). United Nations Scientific Committee on the Effects of Atumi

Radiation, Sources and Effects of Ionizing Radiation, 1977 Report to the

Seneral Assembly, with Annexes, Sales No. E.77.1X.1 (United Nat' 'n . Vow 'ork). 
APPENDIX C: REGULATIONS PERTAINING TO RADIOACTIVE

WASTE MANAGEMENT IN MASSACHUSETTS 


\section{TABLE OF CONTENTS}

Section

A.

B.

C.

D.

E.

F.

G.

H.

I.

J.

$\mathrm{K}$.

L.

M.

N.

o.
Description

Purpose . . ... . . . . . . . . 3

Scope and Application ............ 3

Definitions ................ 3

Exemptions and Exceptions ........... 10

Registration ................ 13

Radiation Protection Guides and

Radioactivity Concentration Guides and

Application Thereof . . . . . . . . 14 Responsibility ............... 18

Surveys and Monitoring . . . . . . . 19

Records and Reports of Individuals . . . . . 19

Storage of Radioactive Materials ....... 21

Radioactive Contamination Control

and Removal ............... 21

Use of Caution Signs, Labels, and

Signals . . . . . . . . . . . . 22

Disposal of Radioactive Materials

and Wastes .............. 23

General Requirements ............ 25

Severability . . . . . . . . . . . 26 
A. Purpose

A.1 These rules and regulations are established for the protection of the general publlc and incivicuals against radiation bazards associated with the use, transportat1oa, storage, packaging, sale, distribution, production, and disposal of radioactive materials and with the use of machloes which enft lonizing radiation. It is the intent and purpose of these regulations to minimize the subjection of incivicuals to lonizing radiation and, where controllable, to mantain absorbed doses of lonizing zadiation recelved by Incividuals as far below the doses specified by tie Rediation Protection Guides (IPG) of these regulations (Section F) as is reasonable and practicable.

B. Scope and Apglication

3.1 These regulations apply to all persons who receive, zossess, use or transfer radioactive materials or cacbines which emit or may emit lonizing radiation in the Comonwealth except as exenpted by the provisions of Section $D$ of these regulations.

B.2 These rules and regulations are in adiition and supplementary to any other legal rules and regulatiors acopted by the Departnent or otber legaliy empowered agency or political subdivision of the Comonirealth.

B.3 In the course of its inspections relative to and enforcereat of these regulations, it is the intention of the Departrent to cooperate with and coordinate its activities with those of the Department of Lajor and Industies of the Comonrealth and to concers Itself, fa the area of employee protection, prinarilis rith those users registered with it under the provisions of Section $\Sigma$ of these regulations.

3.4 iothing is these regulatlons shall ifmit the kind and amount of ionizizs radiation that cay be intentionaly adrizistered to an individual for ciasnostfe, therapeutic, or medical research purposes by or uncer the direction of a physician, dentist, or chiroposist (zodiatrist).

\section{Des̃nitions}

Secause the rrecise meaning given to one or =0re critical terms frequentiy ceter-ines the interpretation of a statement, the following definitions are given scr certain woris and pinzases as tisey are lised in these rejuletions c:

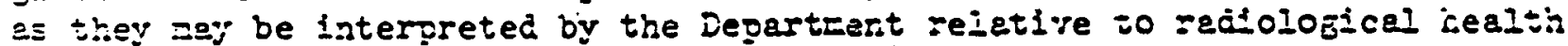
zatters. The list is sot intenced to je a cozplete glossarg of radietion terminoloss. 
ASSOFBED DOSE zeans the amount of eperg ifparted to matter by fonfzing rediation per luit mass of irradiated material at the place of interest (a unit of absorbed dose is the red). In these regulations the absorbed dose in rem is the RBE dose.

-Internal absorbed dose meens an absorbed dose resulting from radioactive substances rithin the body.

- Externel absorbed dose means an absorbed dose resulting from a source(s) of lonlizing rediation located external to the body.

ACCIDEFT means an unforeseeable event or occurrence.

ADDED FIITIR means the Niter acied to the inherent filtration.

AIRBORIE RADIOACTIVE MATERIAL means a-y radioactive materlal dispersed in the eir in the form of dusts, fures, ufsts, vapors of gasses.

AIRBORIE RADIOACTIVITY AREA means:

8. any room, enclosure, or operating area in which airborne radioactive saterial extst in concentrations in excess of the Radoactivity Concentrat1on Guide (RCG); or,

3. any room, enclosure, or operating area in which alrborae radioactive material exists in concentrations whlch, everaged orer ibe number of bours in any week during which individuals are in the area, exceed 25 percent of the RCG.

AIUMINTM EQUIVAIJIN means the thickness of aluminum affording the same attenuation, under specifled conditions, as the materlal in question. ATHOSPInRE meens the gaseous Ruid surrounding the earth; the alr. ATIMUTATION means the process by whlch a beem of fonizizg radiation is reduced in intensity when passing through material.

BARRIIR - SE PROTSCTIVE BARRIER.

BEAM Deans the unidirectional or approxisately unidirectionel flow of lonizing radiation.

CALERDAR QUARTER means :

e. a period of tize not less than 12 consecutive calendar veeks and not Ereater then 14 consecutive calendar weeks; or,

b. \& period of tize of 3 consecutive calencer months. 
COFSTALT POTEITIAI $(c p)$ means, in radological practice, a unidirectional jotential (or voltage) whlch has little or so periodic varfation.

COITROLIED AREA means a deflned ares acsess to which is controlled for the purpose of raaiation protection.

CUIIE - SEe RADIOACTIVITY.

DEAD-MAN SWITCH means a switch so constructed that a circult-closing contact can only be raintained through continuous pressure exerted by tine operator.

DEPARI:IRiT means the Department of Public Beaitb of the Comonrealih of Uassachusetts.

DIAGIOSTIC-TYPE PROTECTIVE TUBE BOUSIJG means an $x$-ray tube bousing so constructed that the leakage radiation at a distance of 1 meter from the terget cennot exceed 100 milliroentgens in 1 kour when the tube is being operated at any of its specifle ratings.

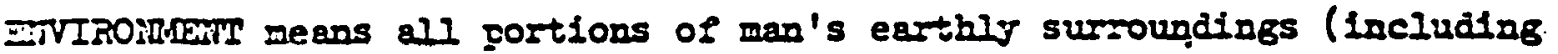
tive atrosphere) fequentable and/or utilized directly or indirectly by man.

EXPOSURE DOSE means the dose potential to dellver an absorbed dose at a speciflc place or location.

FIT' BADGE =eans a packet of appropriatels sensitized zaterial and filters used to determine amounts of lonizing radiation.

FITER means a device which rhen placed in a beem of lonizing radiation rill ebsorb preferentially the less penetrating fonialng radistions.

EALF-VAIUI IAYER (hVI) means the thickness of an absorber required to reduce $a$ beem of lonfing radiation to one-ball its incident intensity.

EIGI RADIATIOH AREA means any area, accessible to and Visitable by 1aairiduals, in which there exists lonizing radiation at such levels that a esjor portion of the body could receire in any one bour an absorbed dose in excess of 100 mijitres.

I:IDIDEm means \& foreseeable evect or occurrence.

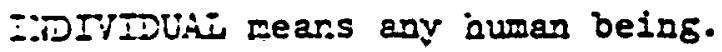


Pege 6.

FIHEREMT FIITRATION means filtration in the usable beam caused by the window of the $x$-ray tube and eny germanent tube enclosure or components thereor.

IISTALLATION means a source(s), Wtid its associated equigment and the space in rbict it is located erd/or usea.

IITTRIAL ALSORBED LOSE - SEe ARSORBED DOSE.

ICHIZING RADIATION means any electrcnagpetic or garticulate radiation cepable of producing lors, directly or icalrectly, in its passage through matter.

KIIOVOLTS PEAK (kTp) means the crest value in kilorolts of the potential of a pulsating potential generator. When only one-helf of the rave is used, the value refers to the useful balf of the rave.

IFAD EQUIVATEAT means the thickness of lead affording the sare attenuatIOn, under specifled conditions, as the materlal in question.

IEARAGE RADIATION means all locizing radiation coming from within the tube housing except the usable beam.

MAXTIM PERLISSIBLE ACCLMULATED DOSE (MPAD) means the absorbed dose which, if accuinlated during the lifetime of an individual and on the basis of present krowledge, is acceptable to the Departaent.

IIIIIROEMGI (m) means oxe-thousenth of a roentgen.

MITOR means anj buman being who has not reached the efghteenth anaiversary of his or her birth date.

1:CNIIORIiG reens the deterainetion of the amount of ionizing radiation or radioactive contamination present in an area or of the exposure dose received by an individual.

OCCUPANCY IACTOR means the factor Which, for ourgoses of evaluating the bazards from lonizing rediation, may be used when mekiag allowances for the percentage of time a incividual occupies a specified erea.

OCCUBAIICIAI ICSE nears the absorbed dose received by an indiricual whose duties of eppioyment directiy or idarrectly may result in exposure to icnizing raciation in the course of said efploysent.

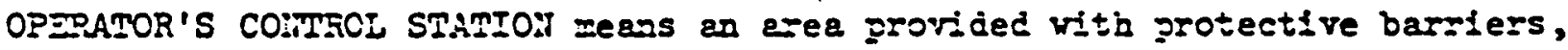
including a patient-vlewlas device and a meens of comunicating audibly and clearly with the patient, to pernit operation without causing the overetor occupationaliy inrolved with ionfing rediation to receive an absorbed dose in excess of the RPG of these regulations. 
Pege 7.

PERSON meens an Individual, cartzership, associat10n, syadlcate, corpany, 11 , trust, corporat1on, departrent, bureau, agency, organizat1on, institution, political subdivision, or any otber entity recogalzed by law as the subject of Figits and duties.

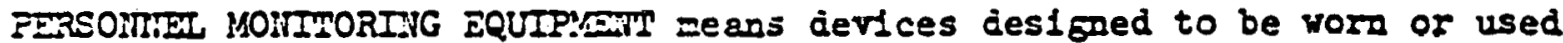
for the purpose of evaluatiag ina expcsure dose of individuals (e.g., IIIm jaciges, pocket chambers, pocket cosireiers, and fla rings).

PROTECTIVE BARRIER means a barzie: of sttentiating materials used to reduce rediation exposure.

- Primary protective baryer means a barrfer surilcient to attenrate the usable beam to the required degree.

- Secondary protective barfer means a barrier sufrlcleat to attenuate stray radiation to the required degree.

QUALIFIED EXPERT means an individual having the kowledge and tralning necessary to meesure lonizing raciation and to advise regarding lonizing radiation and decontamination.

RAD peans "rediation absorbed dose" and is a measure of the energo imparted to matter by lonizing radiation per unit mass of irrsdiated material at tije place of interest. "One rad is the messure corresponding to the absorption of 100 erg3 per grom or matter; one millisad (Irad) = 0.001 sad."

RADIATION -See IONIZING RADIATIOR.

PADIATION AREA means any area accossible to iadividuals in which there exists ionlzing radiation at suci levels that a major portion of the body of such individuals could raceive an absorbed cose in excess of:

a. 5 milirem in any one bour; or,

b. 200 milirem in any fire consecutive cajs.

GADIATION CAUTION SYBOL meens the conventional three-bladed desigo shown below with dimension ratios and colors employed es kere specined: 
a. Design:

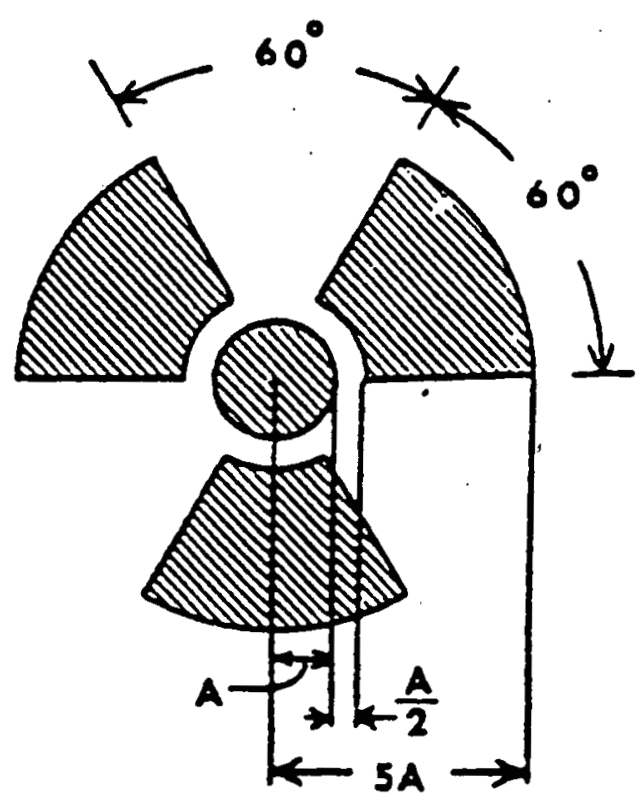

b. Colors employed: the cross-hatched area of the symbol and required letteriss shall be colcred magenta or purple and the background of the label or sign upon which it appears shall be colored yellow.

BADIAmION MACIIVE meens any device capable of produclus ionizing radiation whez operated.

RADIATION PROTECIOI GUIDE (RPG) Means the absorbed dose which shall not be exceeded latentionally inthout approvel of the Department and only after careful consideration of the reasons for dolng so. Every effort anj precaution should be teiken to keep the ebsorbed dose as far below this guide as is practicable.

RADIATION SURVEY Deans the eveluation of the fonizing radiation hazards in and around an installation. It customerily includes a physical survey of the arrangerent and use of the source(s) and measurements of the exposure rates uncer expected cperatiag conditions.

RADIOACTIVE NATERIAI means any materiel (solid, liquid, or gaseous) wich spontaneously emits lonizing raaiation. 
Page 9.

RADIOACIIVITY is the distinguishing physical characteristic of racioactive materials which shall be measured in terns of disintegrations per unit time or in curies. One curie $(c)=3.7 \times 10^{10}$ disintegrations per second (dps) $=2.2 \times 10^{12}$ disintegrations per ninute (dpm). A comonly used sub-multiple of the curie is the microcurie (uc). One Hc $=10^{-6} \mathrm{c}=3.7 \times 10^{4} \mathrm{dps}=2.2 \times 10^{6} \mathrm{~d}$.

RADIOACTIVITY CORCMHMATION means the emount of radioactifity due to a radionuclide or radionuclides quantitatively and qualitatively present in a specifled unit rolume or veight of matter.

RADIOACTIVIIY CONCENTRATION GUIDE (RCG) means that concentration of a radfonuelide or radionuclides in the air, vater, or foodstuffs of man's environment areraged over a period of 13 consecutive reeks wich vould result in an exposure dose equal to the absorbed dose of the Radiation Protection Guides (RPG) for porticas of the buman body of concern. Where and when more than one radionuclide is present in the concentration the gross effect of the mixture shall be consldered.

RBE DOSE means the "relative blologlcel effectiveness" dose due to different types of lonizing radiation. It is numerlcalls equal to the product of the dose in rads and an agreed conventional (RBE) factor acceptable to the Department with respect to a particular form of lonizing rediation.

RCG - SE RADIOACIIVITY CORCEIITAUIOI GUIDE.

SEM means a unit of the RBE dose.

ROENTGEN $(r)$ is the unit of exposure dose of $x$ - or game radiation. One roentgen is an exposure dose of $x$ - or gama radiation such that the essoclated corpuscular enfssion per 0.001293 grar of air produces, in afr, ions carring 1 electrostatic unit of quantity of electricity of eitber sign.

RPG SEe RADIATION FROTECTIOII GUIDE.

SCATIERED RADIATION means loniziag radiation that, duriag passage through matter, has been deviated in direction. It may also bave been modified by a decrease in enerz.

SEATED SOURCE means any radioactive material and the permenent container encasing it in a maner lnteaded to prevent leakage of the radioactive material which is intenced for use in its entirety es a source.

SECOIDARY RADIAIION means fonlzing radiation enttted by an irradiated material. 
SEII-PERMANEHILY ATTACHED means devices attached by 3imple mechanical means (spring clips, etc.) which are removable but not ilkely to become detached during ordinary usage.

SIALL denotes that the ensuing recomendation is necessary or essential to neet the currently accepted standards of protection.

SEOUTD, OI IS RECOMEUDED, Lndicates advisory recomendations that are to be applied when practicable.

SEUIMER means a cevlce, generally of lead, attached to an x-ray tube housiag to intercept the usable beam.

SOURCE means radioactive material or a radiation machine.

STRAY RADIATION means loniziag radiation not serving anj purposerul use. It includes leakage and secondary radiation.

THETPAPEUTC-TYPE PROTSCTIVE TUBE HOUSIITG means an $x$-ray tube housing so constructed that the leakage radiation at a distance of 1 meter from the target cennot exceed 1 roentgen in 1 hour and at a distance of $5 \mathrm{~cm}$. From any point on the surface of the housing accessible to the patient cannot exceed 30 roeatgens in 1 hour when the tube is belng operated at any of its specifled ratings.

MCTAI FIITHR means the sum of the lwbereat and added Mlters.

USABLE BEAM means the lonizing zadiation which passes through the vindor, aperture, cone, or other collimating device of the source.

USI IACTOR means the fraction of the woriclosd during wilch the usable beam is polnted in the direction under consideration.

USER reans a person having acministrative and/or responsible control over one or more installations.

WORKCOAD Is a measure of the radiation output of a radiation machine expressed in mill1anpere midutes per week or roentgens per week at 1 meter rran the source.

$X-R A Y$ APPARATUS mears eny radiation machine designed to produce $x$-rays.

D. Exempicas and Exceptions.

D.1 The following materiels, machines, and conditions are exempt from these regulations: 
2. Radoactive materials of an equiralent specific radio activity not exceeding thet of natiral potassium $\left(10^{-9} \mathrm{c}\right.$ Der s.)

b. Quantities of redioactive naterials not exceeaing the emounts set forth in mable 1 , provided the user does not possess =ore than 10 suci quantities and also providea the dose rate to the whole body, scrads, active bloodforning orgens, beed end trunt, or leas of eye at the poilt of neerest approach to sush sources coes not exceed 0.5 rem ter year. Tre menufacture of sealed sources shall not be exempt.

c. Radioactive nateriel or naterals in combination or not with non-radloactive material having a radioactivity concentration not exceeding the RCG.

d. Domestic television receivers (except durias production testing and servicing with the sbield remored), provided the dose rate at $5 \mathrm{~cm}$. from any outer surface is less than 0.5 mrem per bour.

e. Dlectrical equi ment that groduces ionizing radiation fncidental to its operation for other purposes, provided the dose rate to the whole bodr, gonads, active blood-forming organs, head and trualk, of lens of eye (under conditions of use) at the point of nearest approach to such equiprent does not exceed 0.5 rem per year. The production testing or factory servicing of such equipment shall not be exempt.

P. Radiat10n mechizes in a state or condition such as to rencer them not copable of beins used to produce lonlzing radiatfon. (For examle, x-ray machines in transport or electrical equipment is storage.)

8. Any radioactire saterial being traisported fntrastate or in intrastate transport in conformance with regulations of ans Governmental asency having a Jurisdiction over safety during inierstate transportation, provlded that regulations of sald esency =eet the ioniziag radiation protection reouirereats of isese regulations.

h. $\quad$ Is=e pieces, instruments, zovelties, or devices containing sel:-luminous meterials $i=$ amounts not greater than those set foria in Colum 1 of Table 1 , except duriag manufacture or repels of the self-luminous ccmponeats themselves. 
TABLE 1.

EXOAPY QUAHTITIES OF RADIOHUCLIDES

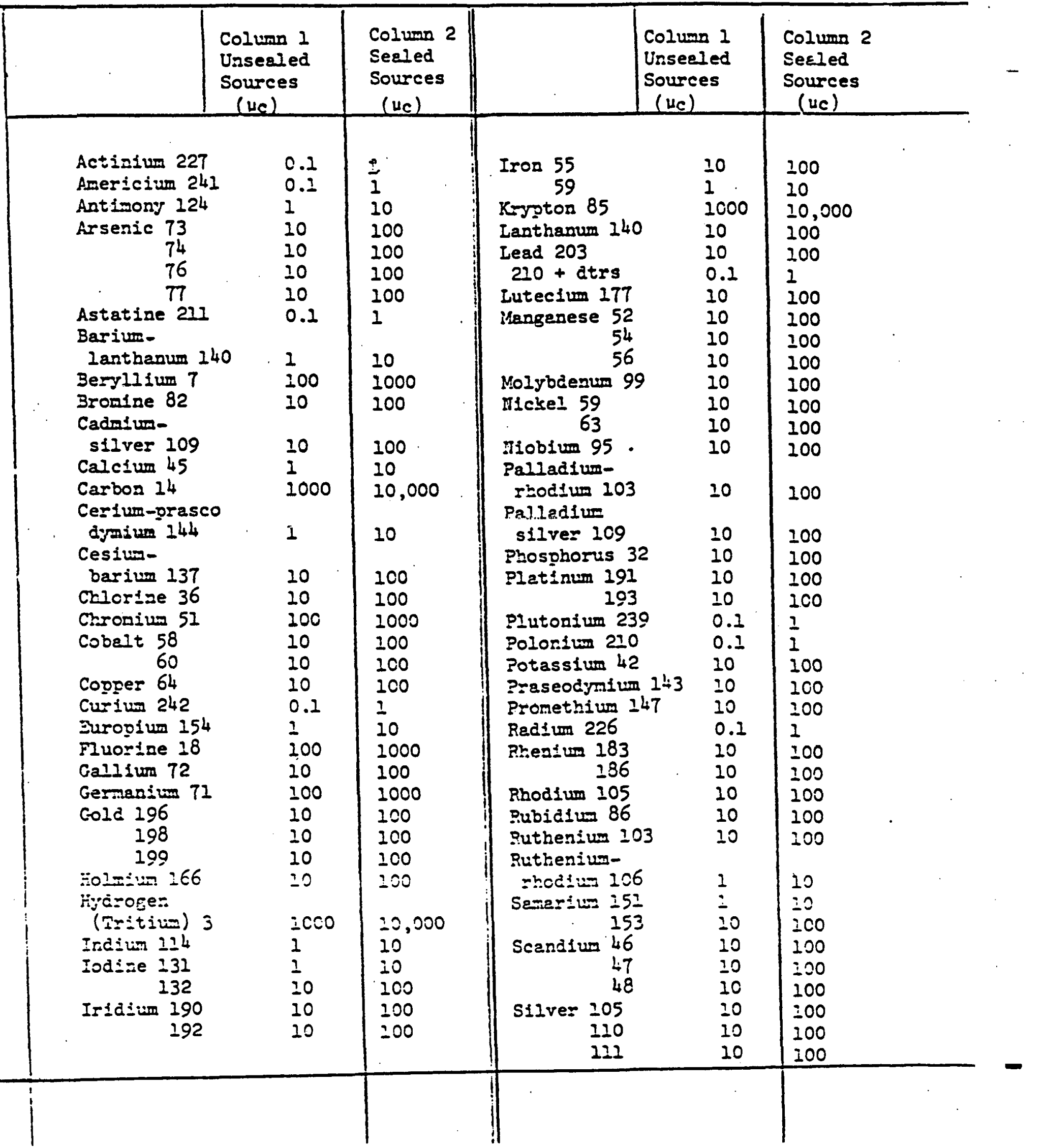




\begin{tabular}{|c|c|c|c|c|c|c|c|}
\hline & $\begin{array}{l}\text { Col } \\
\text { Uns } \\
\text { Sou } \\
(1\end{array}$ & & $\begin{array}{l}\text { Colima } 2 \\
\text { Sealed } \\
\text { Sources } \\
(\mu c)\end{array}$ & & $\begin{array}{l}\text { Coilu } \\
\text { Unse } \\
\text { Sour } \\
\text { ( } 10\end{array}$ & $\begin{array}{l}1 \\
\text { led } \\
\text { es }\end{array}$ & $\begin{array}{l}\text { Columi } 2 \\
\text { Seeled } \\
\text { Sources } \\
(\mu \mathrm{c})\end{array}$ \\
\hline 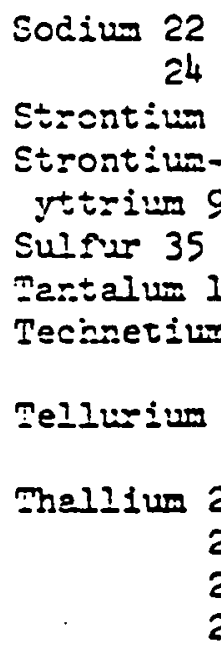 & $\begin{array}{l}89 \\
0 \\
82 \\
96 \\
96 \\
99 \\
127 \\
129 \\
00 \\
01 \\
02 \\
04\end{array}$ & $\begin{array}{l}10 \\
10 \\
1 \\
0.1 \\
10 \\
10 \\
1 \\
1 \\
10 \\
10 \\
10 \\
100 \\
10 \\
20\end{array}$ & $\begin{array}{l}100 \\
100 \\
10 \\
1.0 \\
100 \\
100 \\
10 \\
10 \\
100 \\
100 \\
100 \\
10 c 0 \\
100 \\
100\end{array}$ & 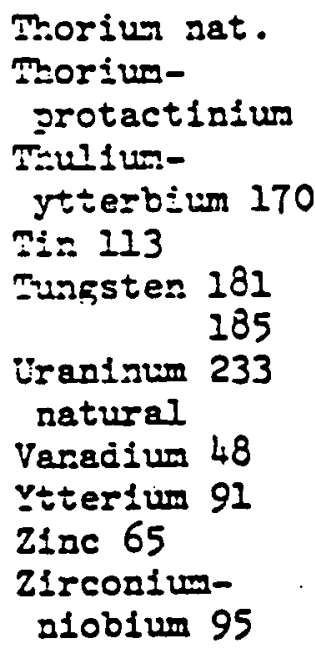 & 23.4 & $\begin{array}{l}100 \\
1 \\
1 \\
10 \\
10 \\
10 \\
0.1 \\
1000 \\
10 \\
1 \\
10 \\
10\end{array}$ & $\begin{array}{l}1000 \\
10 \\
10 \\
200 \\
100 \\
100 \\
1 \\
10,000 \\
100 \\
10 \\
100 \\
100\end{array}$ \\
\hline
\end{tabular}

D.2 In conformance viti Section 3.3, such portions of these regulations as pertain to recoris and reports on employees do not apply to users of sources specis1cally registered ith the Department of Labor and Industries of the Comsonverith, if the user complies with pertinent and compatible provisions of Industrial Bulletin Io. 5 of said Department of Labor and Iadustries.

D.3 The Department may, upon request of any person or upon its own initiatire, make such exemptions and/or exceptions to these regulations as it mes deem appropriate.

E. Registration.

E.I Any existing user, other than one required to be registered rith the Departrent of Labor end Industries of the Ccmonvealth of Massacbusetts, shall register bis installation vith the Departmeat on or before Ausust 1, 1962, and after August 1, 1962, any proposed installation shall be registered by the user tinereof prior to receipt of the source. The application for registration sharl be submitted on a form proviced by the Derartment.

E.2 Dental radiographlc installations uncer tine control of a denzist registered wader the provlsions of Chapter 112 of the General Laws as emended shall be deezed to be registered under the provisions of this section. 
Page 24.

E. 3 Installation(s) in hospitals licensed by the Department under the provisions of Section 71 of Chapter 111 of the General Laws as amended shall be deemed to be registered under the provisions of this section.

E.4 The user shall notify the Department in writiog within 30 days after any changes with respect to his registered installetion which way increase its poiential as a source of iceizing radiation.

E.5 Acknowleajent of registration shall not imply the Depart.dent's epproval of the conditions described in the registration.

I. Radiation Protection Guides (RPG) and Radioactivity Concentration Guides (RCG) and Apolication Thereor.

F.1 Each user shall control all sources of fonlzing rediation for which be is responsible in sich a way as to provide reasonable assurance that no indifidual shall recelve an absorbed dose in excess of the RPG set forth in this section. All absorbed doses of fonfing radiation that individuals are allowed to receive and amounts of radioactive materials released to the environment shall be kept to reasonable minlmums in conformance vith the purpose of these regulations.

F.2 The RPG values set forth in thls section are in addition to those received by the indiviaul from all sources of lonizing radiation naturally present in the environment and from that intentionally administered for diasnostic and therapeutic purposes.

F.3 Radiation Protection Guides (RPG) - Occupational

I.3.1 The RPG's for indiFiduals occupationally involved with lonfing radiation are set forth in Table 2.

F.3.2 The RPG's for any minor, whether or not occupationally infolved directly with ionizing zadiation, are set forth in Table 3 .

T.4 Radietion Protection Guides (MPG) - Non-Occupetional and Minors.

F.4.1 The RPG's for individuals not occupationaly involved witb ionizing radiation are set scth in Table 3.

3.4.2 The KPG's for any winor, whether or not occupationally inrolved directly with lonizing radiation, are set fortin in Table 3 . 
TABI.F. 2.

RADIATION PROTECTION GUIDES (RPG) - OCCI:P.ITION.AI.ADIJIT

ABSORBED DOSES TO ADULT INIJIVIDUAISS

OCCUPATIONAI.LY INVOI.VED WITII IONIZING, RADIATION

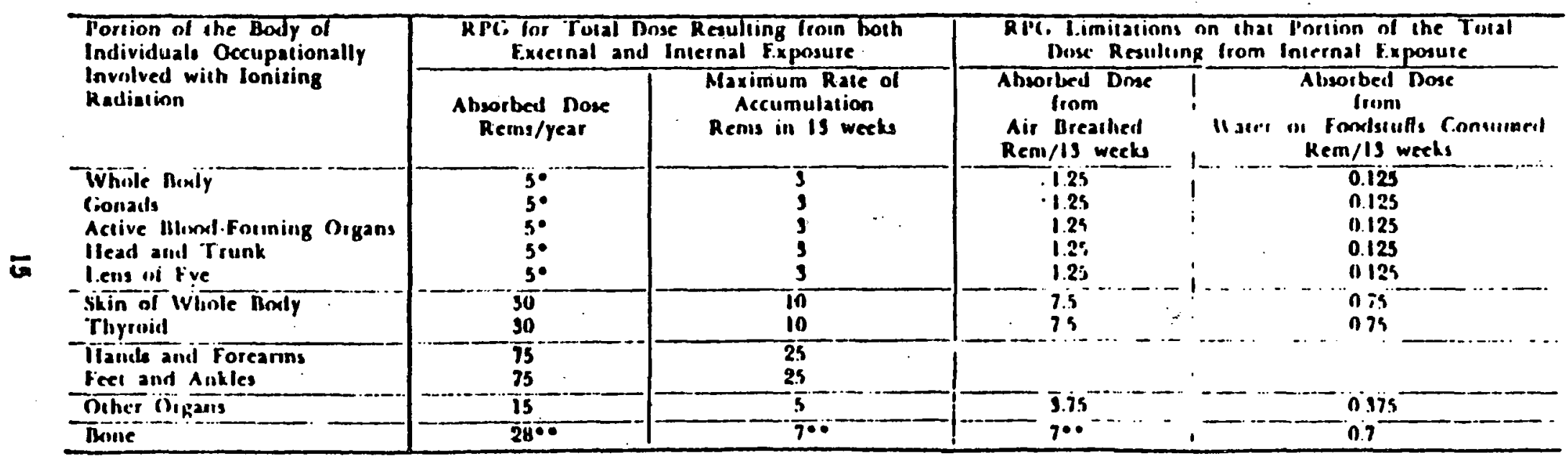

- Foumula: This Rfl: lemul ol 5 reon may be cxceeded provided lliat:

in! llie user has deteranined the indivulual's previously accumulated occupational ane. and

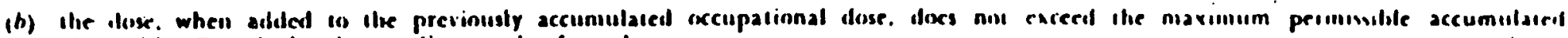

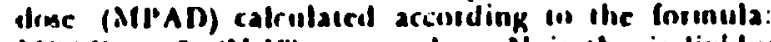
$A I P A I I=5$ (N.IH) ienus. where $N$ is the indiviluals age in lull rears: and.

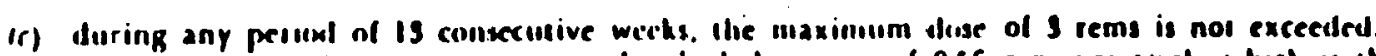

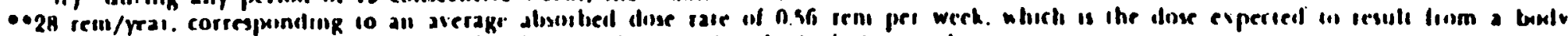

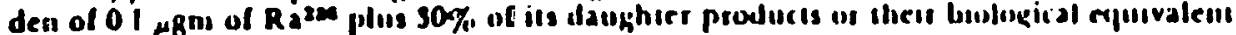


TABLE 3.

RADIATION PHOTEC:TION GUIDES (RPG) - NONOC:CUP.IIION.M. IND IIIORS ABSOR RED DOSES TO IXIIVIDU.II.S NOT OC.CUP.ITIO.V.MII.Y INVOLVED WITH IONIZING RAIIITION INI III.VORS

\begin{tabular}{|c|c|c|c|c|c|c|}
\hline \multirow{3}{*}{$\begin{array}{l}\text { Aopect of the Ceneral } \\
\text { Environmelit in and/or } \\
\text { Irom Which an Indlvidual } \\
\text { Might Be Exposed 10 } \\
\text { lonizing Radiation }\end{array}$} & \multicolumn{6}{|c|}{ 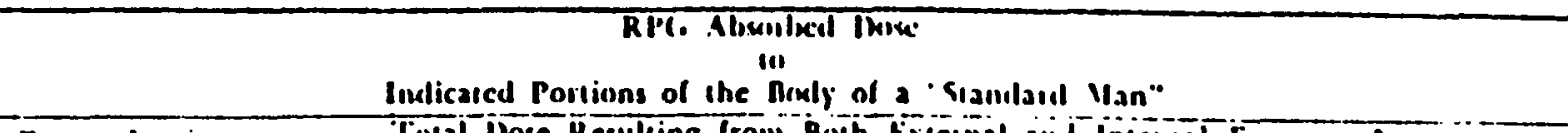 } \\
\hline & \multirow{2}{*}{$\begin{array}{l}\text { Exicrnal } \\
\text { Exposure } \\
\text { pose } \\
\text { Only } \\
\text { To } \\
\text { Whole } \\
\text { Body }\end{array}$} & \multicolumn{5}{|c|}{ 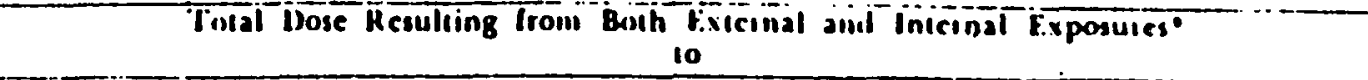 } \\
\hline & & $\begin{array}{l}\text { Thole Body } \\
\text { Conads } \\
\text { lce. Al. Form. Organs } \\
\text { llead and Trunk } \\
\text { lens of Eye }\end{array}$ & $\begin{array}{l}\text { Skin of Wh. Body } \\
\text { Thyroid }\end{array}$ & $\begin{array}{l}\text { Ilamils ami } \\
\text { Foreauns } \\
\text { Feet and } \\
\text { Inkles }\end{array}$ & $\begin{array}{l}\text { Oiber } \\
\text { Oigans }\end{array}$ & Bnne $\cdots$ \\
\hline $\begin{array}{l}\text { Air Drealied and Water } \\
\text { and Foodutufi } \\
\text { Consumed } \\
\text { (Internal Exposure) }\end{array}$ & & $\begin{array}{l}\text { Not more } \\
\text { llian } 0.125 \\
\text { rem in } 13 \\
\text { consec. whe. }\end{array}$ & $\begin{array}{l}\text { No! more } \\
\text { than } 0.75 \text { rein } \\
\text { in is consec. } \\
\text { whe. }\end{array}$ & $\begin{array}{l}\text { Not more } \\
\text { ihan } \\
1.875 \text { rem } \\
\text { in } 13 \text { whs. }\end{array}$ & $\begin{array}{l}\text { Not more } \\
\text { than } \\
0.375 \text { reen } \\
\text { in } 19 \text { whe. }\end{array}$ & $\begin{array}{l}\text { Not more } \\
\text { than } \\
0.7 \text { rem } \\
\text { in } 13 \text { wh. }\end{array}$ \\
\hline
\end{tabular}

- Not more than $0.5 \mathrm{rem} / \mathrm{yr}$. of the indicated tocal yearly donca shall reaull from extemal exposure. 
Page 17.

F.5 RadioactivitJ Concentration Guides (RCG).

F.5.1 The RCG referred to in these regulations is that concentration of a raoionuclide or mixture of radionuclides in the air, water, of food portlons of man's environment inici, ceiculated on the basis of most recent scientific koorledze and assumptions acceptsble to the Departient, would cause an absorbed dose or doses of lonlaing radiation equal to the occupational or non-occupational RPG (whicherer is of indicated concen) of these regulations. Such recommendations of recogaized authorities, such as the ilational Comittee on Radiation Protection and Measurements, as mas, from time to time, be acceptable to the Department may be used in the calculation or determination of the applicable RCG, but sald recommenditions are not to be construed as part of these regulations. In the apolication of the RCG, the user shall take cognizance of all sources from which any individual may, or is $11 k e l y$ to, receive an absorbed dose, and the total absorbed dose from all such sources shair not exceed the RPG.

F.6 Applicstion of Rediation Protection Guides (3PG) and Radioactivity Concentration Guides (RCG).

F.6.1 When radioactive naterials are released to the eivironment and may cause an internal absorbed dose, the radioactivity concentration in that portion of the envilonment from which the radioactive naterial may be absorbed by the body shall be controlled by limiting the anounts and =ates at which such raterials are released to the enrironent. In the application of this section, the radloactivity concentration in tie air, water, or foodstur:s taken into the body, averaged over any period of 13 consecutive veeks, sball aot exceed the RCG.

F.6.2 When the exteranl absorbed dose to the tissues of the body results froll racicactifity concentrations in tibe atrosthere, the radioactivity cencentration shali be controlled by limiting the emounts aca retes at which such materials ere releesed to the etrospiere and such concentrations shail not exceed the RifG. 
Page 18.

F.6.3 When the external absorbed dose to the tissues of the body results from ioniring radiation from sources 10cated in controlled areas, the absorbed cose to the indiridual shall be controlled through utilization and application of exposure, occupancy, and shielding factors and shall not exceed the RPG.

F.6.4 In meeting the requirements for the protection of individuels agaiast hazaris associated with sources of lonizing radietion subject to responsible control and/or radioactive material escaping controlled areas or being discharged to the enviroment, the user may make reasonable allowances for exposure and occupancy fectors and nanmace or natural environmental pheromens.

F.6.5 Recomendations of the Hational Combittee on Radiation Protection and Measurements may be used as guldes or es beses for calculating to obtain or maintain adequate protection for the general prbllc and indifiduals against bazards associated with sources of lonizing radiation within the mesning of these regulations, but said recommendatfons shell not be considered, in whole or in part, as a portion of these regulations.

\section{G. Responsibility.}

G.1 The user shall be responsible for and shall establisb orerating rules and procedures which will profide reasonable assurance that the otier provisions of these regulations rill be carifed out, and the user shculd keep himself informed on procedures and methods based upon current developments and recomendations of knowledgable authorities such es the ilational Cowittee on Radiation Protection and Measurements.

G.2 Were necessary to assure compliance with the other provistons of these regulations, the user shall provide, or have readily arailable at his disfosal, properly naintained and calibrated instruments adequate for the detection and messurement of ionizing radiation.

G.3 The user shell protice and require use of safety devices and écuipent, for rrotection egainst the hezaris of ionizing reciatica, to anc by every izdiricial (i=ciuains visitors) admitted to his installation end shall enforce all ionizing radiation safety rules that concern or affect said individual's coniuct and shall provide, or cause to be proviced, any necessary instuction concerning the attendant ionizi=s radietion bazards. 
G.4 The user shall make an evaluation of his installation's nuclear incident potential, take appropriate steps to guard against such an occurrence, and establish an emergency plan, as nay be indicated, to minimize the hazara lron ionlzing raciation to his employees and the generel public and damage to private and gublic property that may result from such an incident. The user shall inforn the Department of is emergency plen and, in the event of suci an incident, shall notify the Defartment and institute such portions of his plan es may be deemed reasorable and adrisable. Sucj action as the user may take in confor-ance with such a plan submitted to and approved by the Jepartment shall not be deemed in violation of these regulations.

G.5 In the event of an accident that may result in a nuclear occurrence, the user shall appraise the situation and take such reasonable and appropriate steps as may be indicated on the basis of information avallable, to minimize the hazard from lonizing radiation and danger to his emoloyees and the general public. Such reasonable action as may be taken under this section siall not be considered a violation of these regulations.

z. Surveys and Monttoring.

E.1 The user sinall provide for adequate surveys and monitoriag of areas both Inside and outside the area under bis control, sufFlcient to assure corpliance with other sections of these regulations, and shall maintain records thereor.

B.2 The user shall provide for personnel sonitoring of all ocsupationally exposed indiviauals within a controlled aree. Eorever, such monitoring shall not be required if:

d. the dose to which any said individuel is exposed can be demonstzated to be predictable and, for adults, less than 25 per cent of the RPG (Teile 2) and, for minors, less than 50 per cent of the RPG (Table 3); and,

b. reasonable assurance cen be given that en accident causing exposure in excess of the RPG will not occur.

I. Recoris and Reports.

I.1 Tre user shall keep exposure records such as tway be requi red in Section $\bar{B}$ and siall preserve these recorcs on eaci individual whose name is $c n$ the user's employee roster for a perfod of time of 5 years after termination of employment uniess extended by the Department. When en individual's enployzent is permanently terminated, the user, upon request of the Departzent or sald individual, shell provide the Department and the former employee with a sumery of the records for eech calendar jear of employmeat. These records shall 1aclude the Individual's Social Security aumior. 
Page 20.

I.2 The user shell record the detalis of any circunstances wherein eny indiviaual receives an absorbed aose, as a result of sources under his control, in excess of the RFG. This regulation shall not apply to absorbed doses resulting from ionizing radiation adinistered to an indivicual for diagnostic or therapeutic recical purposes by a pinsicien, centist, or ciriropodist (podiatrist).

I.3 The user shall keep records shoring the date, amount, and kind of racioactive materials received at bis premises from other users and an inventory of such radioactive materlals at his installation.

I.4 The user whose installation contains or employs facilities capable of producing redioactive materials (as in the case of a reactor or particle accelerator) shall keep a record of the kinds and amounts of radioactive products intentionally produced.

I.5 The user shell keep records showing the date, amount, and kind of redioactive materials shipped from his itstallation.

I.6 The user sball keep suffecient records of the kinds and amounts of radioactive materials released from his installation to the environs to demonstrate compliance witb other sections of these regulations.

I. 7 When it is known or belisved that an ladividual(s) may have received an absorbed dose in excess of the applicable RPG, the user shall report to the Depertzent by leiter, within 7 days of the discovery, all of the fects relerent to the incident or accident and shall place a copy of the report in that indivcual's personnel file if he be an employee. Absorbed doses in excess of 5 times the annual allowaile RPG shall be reported imediately. This reguletion shell not apply to absorbed doses zesulting Irom lonizing radiation administered to an individuel for diagnostic or therapeutic mealcal purposes by a physician, dentist, or chiropodist (podiatrist).

I.8 Except as approved by the Department, the user shall report to ine Department within 24 hours (seid report to be confireed by letter) eny release of radioactive aterial to the entizons of:

a. a concentration which, when averaged over 24 hours, exceeds 500 ilmes the KCG; or, 
Page 21.

b. a total quantity, in any 24-hour period, which exceeds 100 tines. the amount set forth in Colum 1 of mable 1 of these regulations.

I.9 The loss or theft of or damage oy fire, explosion, natural phecomena, or accident to any source siall be reported by telephone to the Depertment within 24 hours, asd said report shall be confirmed by letter.

I.10 All records referred to in Secticas $\ddot{B}$ and I shall be made available to the Department upon request.

I. Storage of Radioactive Naterials.

J.I Raaloactive naterials shall be kept or stored in a maraer that will provide reasonaile assurance thet no indi fidual will receive an absorbed dose in excess of the RPG. In this regard, precautions to mintinize exposure to iontzing radiation of ang individual in the event of fire, earthquake, flood, vindstorm, explosion, or other emergency should be taken, and the storage facilities should be sultably desioned with respect thereto.

J.2 Any radioactive material in storage shall be secured ajainst unauthorized renoral from the place of storege.

J.3 The user shall notify the local Fre department of the presence on his premises of any radicactlve material that ary present special fre-ffinting problems or require special precautionary meesures in case of fire or otber natural catastrophe, and be shall establish effective liaison with the fife departient in regard to this matter.

K. Radionctive Contamination Control and Remoral.

K.I All work rith radioective materials shell be carried out under such conditions as to minimize the possibility of any contamination that vould result in any ladividuel receiving an absorbed cose in excess of the RPG.

K.2 Ivery person using racioactive zule:iel otion than a seeled solicce siall have on jand or imeatately evailable an insirunent(s), procerly calibrated and aainteined, suitable for the detection and zeesurement of contanination in accorciace with the requirements of this section. The Departaent may require tine same or similar instrumentation for users of sealed sources. 
Page 22.

K. 3 The Department may require a suitable pattern of work rules apolicable to indivicual users, as may be indicated.

I. Use of Caution Signs, Labels, and Signals.

I.I The user shall 1rdicate the presence of fonizing raciation in certain areas by posting conspicuous signs or labels rialci beer the radiation caution symol and appropriate wording (as set forth in Tabis 4) to explain the nature and incicate tine existence of the tazard. The use of suci sigas for other than this express purpcse is probibited, and the user siall remove all such sigas and labels when no longer reguired by the provisions of these regulations. This regulation shall not apply to areas used for medical, dental, chlropodal, end veterinary $x$-ray disoosis or therapy.

L.2 Each high radiation area shall be equipped with an internal cortrol circuit which shall either cause the level of ionizing radiation to be reduced below that at which an indf vidual might receive an absorbed dose of 100 mrem in any one hour when in the area or shall energize a conspicuous fisible or audible alars sigar or a barricade suitaibly lebeled in such a manner that the individual, when entering the arsa, and the respons1ble person in charge are made aware of the individual's entry into said ares. If an area is a high radation area for a period of tire of 30 consecutive days or less, a control circuit is not required proviled that a barzicade (such as a fence or rope) is erected, the required caution sizos are posted, and the area is kept under surveillacce by the user or his designated representative.

I.3 AIl machines and devlces capable of enftting lonizing radistion and all contalners, source bolders, nanuisctured procucts, or other things containing a quaitity of radioactive material in an amount oreater then the quantities set fortb in Table 1 shall be provided with and bear a durable, clearly visible label on which are inprinted the radiation caution syriool and suitable and descriptive words of caution.

L. 4 In addition to providins tide stancard rediation-hezard symol, each contalner of racioactive material skali be iabeled in such a maner that the kizd and quentity of material, date of meesirerext, and the name of the person designated responsible for the material can be easily and quickly ietermined. 
TABLE 4.

CAUTION SIGN AND SIGNAL. DEVICE REQUIREMIENTS

(Where Reguired and Description Thereol)

\begin{tabular}{|c|c|c|c|}
\hline \multirow{3}{*}{ Area of Concern } & \multicolumn{3}{|c|}{ Required } \\
\hline & \multicolumn{2}{|c|}{ Crution Signs Conlaining } & \multirow[b]{2}{*}{ Additional Requirement } \\
\hline & $\begin{array}{c}\text { Radilation Caution } \\
\text { Symbol }\end{array}$ & $\begin{array}{c}\text { Cautioning } \\
\text { Words }\end{array}$ & \\
\hline a) Ralialion Areas & Yes & $\begin{array}{l}\text { Caution (or Danger) } \\
\text { Radiation Area }\end{array}$ & None \\
\hline b) Iligh Radiation Area & $\overline{Y a}$ & $\begin{array}{l}\text { Caution (or Danger) } \\
\text { Iligh Radiation Area }\end{array}$ & See Seci. L.2 \\
\hline c) Airlorne Radioactivily Area & $\bar{\gamma} \bar{e}$ & $\begin{array}{l}\text { Caution (or Danger) } \\
\text { Airborne Radinactivity Area }\end{array}$ & $\begin{array}{l}\text { Sce Sect. } 1.2 \text { if area is alma } \\
\text { Iligh Radlation Area }\end{array}$ \\
\hline $\begin{array}{l}\text { d) Folrance to areas or moms in } \\
\text { which rodioactive material is } \\
\text { used or otored in an amouni } \\
\text { exceeding } 10 \text { imes tlie mount } \\
\text { of radloactive malerial ex. } \\
\text { eaipted by lable l. }\end{array}$ & $\overline{\mathbf{Y e r}}$ & $\begin{array}{l}\text { Caotion (or Danger) } \\
\text { Radioaclive Material(s) (and, wherc } \\
\text { praclical. describe lhe quantitics } \\
\text { and Minds of radioactive materials } \\
\text { involved) }\end{array}$ & - \\
\hline e) Radiation Macline & $\mathbf{Y a}$ & Callion (or Danger) Ralliation & T.abel placed on the coniral \\
\hline In the case of $x$-ray machines only & Yes & Caution (or Dauper) X.ray Area & \\
\hline
\end{tabular}


Page 23.

\section{L.5 Exemptions from Posting and Labeling Reguirements.}

L.5.1 Rooms or other arees in hospitals are not required to be posted with caution signs because of the presence of patients containing radioactive material(s) proviced that attendant personnel are acequately instructed as to the precautions necessary to prevent the exposure of any individual to fonizing rediation or alrborne radioactive materials in excess of the limits established by these regulations.

I.5.2 Caution sizns are not required to be posted at rooms and arees containing radioactive material(s) for periods of less then 8 bours, provlded that such material(s) are so attended during such periods that there is no chance that any individual could enter the area or room without knowing that a bazard exists.

L.5.3 The labeling requirement provisions set forth in SectIon L.3 do not apply if:

a. the radioactivity concentration does not exceed the RCG; and

b. the absorbed dose to an individual a113 not exceed the RPG (ion-Occupational and Minors) set forth in Table 3; and

c. the quantity of the redioactive material 1nvolved does not exceed such quantities of racioactive naterials as are exempt wader the provisions of these regulations; or

d. In the case of laboratory containers ( $\mathrm{e} .8$, beeisers, llasks, and test tubes, used translently in laboratory procedures), the user is fresent; or

e. the source is a radiation machine in a controlled area of a medical, dental, ciriropodal, or veterinary installation.

M. Disposel of Radioactive Katerials anc Hastes.

M.I Ho user shall release radioactive material (s) into the ais or rater or dispose of such materiel(s) by burial in such a manner that it may result in any individual receiviag an absorbed dose 
Page 24.

of ioniziag radiation in excess of the DPG. In the apolication of and the conforming with the provisions of this regulation, the user siall investigate the possibility of the discharge(s) of radioactive rastes to the same environs by enother user(s) anc, upon becoming cognizant of such comon use of the ezvirons, shall ccoperate with seid other user(s) in establishins and echering to mutuaily eEreeable promrata limitations upon theif respective reieases and file with the Department a siatement setiing forth the terms of such an asreement. If such an agreerest is not executed rithic a reasonabie tire, the Department may arbitrarily assign quantitative limits and/or conaitions of such releases to the users severaliy.

M.2 Each user shall control the release or discharge of radioactive materials to the ataosphere, laland or tidal waters, sewerage systems, etc., on the following basis:

The averese radioactivity concentration of the airborne or vateriorne redionuclide(s) at points of release from control of the user shall not exceed the.RCG. Fowerer, with the approvel of the Departient, the user may exceed the RCG after demonstrating to the satisfaction of the Department the necessity therefor ard the appropriateness of meking reasonable use of and allowences for occupency, dilution, dispersion, and the environmental and other factors, provided (1) tie radioactive materlal beiss disciarged to inland or tidel raters or to a serer system is soluole is water, (a) ise averase radioactivity concentration of the raijonuclice(s) created in the environment (or portions thereof) at coints requented or used by individuals does not exceed the SCG, and (3) the total quantities of the radionuclice(s) released in eny pericd of 24 consecutive hours shall not exceed 100 tires the quantities listed in Table I, Colum 1 .

M. 3 io radioactive saterial in an amount in excess of that contained in Table 1 shall be ifsposed of by burial in the ground or in or on a land durp or stored (contained or uncontaineci) in or on unenclosed sround without the approval thereof $\mathrm{ky}$ tine Department.

M.4 The user shall keep records of all sales, transiers, anc/or aisposal or any scurcels). 
Page 25.

M.5 liothing in these regulations shall be construed as permitting the release or disposal of materials in a manner which would be unlawful for other reasons.

ii. General Requirements.

i.l A user should require an employee or potential employee to subwit to an appropriate medical examination prior to the employee's assionment to an operation where he may recelve, or is likely to receive, an absorbed dose in any celender quarter in excess of 25 per cent of the RPG, or said employee will be, or is likely to be, exposed to airborse radioactive materfal (s) in an arerage concentration in excess of 10 per cent of the RCG and thereafter as may be required by the user, and shall proflde the employee vith a copy of the report of seid medical examination upon the emoloyee's request.

H.2 No food, Including cands and beverages, sinould be brought into, and smoking should be prohibited in, any area where unsealed source(s) of radioactive materlal are being used, handled, processed, or transferred, or stored in a ranner which does not prevent leakage of the radioactive naterial(s). Speciflc notice to this effect should be posted conspicuously in such areas.

II.3 Arter establishnent of specific periods of ti=e to be employed by a user as a calendar quarter, tive user stould make appropriate notation in his pertinent records of ang change therein.

I7.4 The user should formulate suitable emergency plans as cay be indicated to protect bis exployees and the public afairst potential inazards due to his specific source(s), and should rake known the details anc existence of such plass to the Depertient and such otber public agencies baving a concera, such as boards of bealth, fire departments, and police departments.

X. Severability

Insofar as the Depertyent an provide, each section or part tisereof of these regulations shell be construed as seperate, to tie enc inat, if

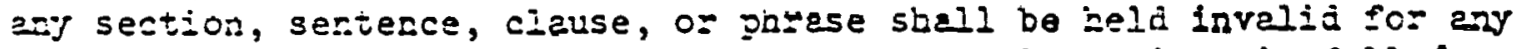
reeron, the remaincer of tiese regulations shail coninue in illi forse. 
Page 26.

CHAPNER 6́́3*

An Act Autiorizing the Defarisent of Fubitc Eealth to Control the Eazards of Ionizing Radiaiion.

Ee it enacted, etc., as follows:

Chapter 111 of the General Laws is bereby amended by striking out Section 53, insezted of Cuepter 335 of the Acts of 1955, and inserting in place thereof the folloring section:-

Section 5B. The departrent may require registration of sources of loaizing radiation and shail, from time to time, after a public hearing, prescribe and establish rules and regulations to control the radiation bazards of redioactive materials and of machines which emit lonizing radiation for the purpose of protecting tine general publis and individuais against hazards associated with the use, transportation, storage, packaging, sale, distribution, production, and disposal thereof. Suci rules and regulations siall not limit the kind and amount of radiation that may be intentionally administered to a person or animal for diagnostic, therapeutic or experinental purposes by or under the direction of a physiclan, dentist, chiropodist (podiatrist), veterinerian or other person licensed to so administer radiation under the laws of the comonrealth. Suci rules and regulations shall be flled with the Messachusetts comission on atomic energ at least thiriy days prior to theis effective date end shall becone effective upon fling with the state secretary, unless a later effective date is specified by the departient. Whoever flolates any such rule or regulation shell be punished by a fine of not less than ten nor more than fifty dollars. Whoever, efter due notice, contirues to violate ens such rule or regulation shall be punished by a if pe of not less than one bundred dollars nor more than Iive bundred doilars to the use of the Comontrealth for each offense. Each day of such violation after suci notice shall constitute a separate offense. The supreme judicial court or superior court upon applicetion of the department, or upon application of any party interested, with the aporoval of the depertaent, nav enforce such rules and reglations, and restrain tie use or occupation of premises or such portion thereof as the depertxent ney specify lotil such rules and regulations have been somplied with.

* Mis Section 53 cf Chacter 111 , as grovided by Chepter 633 of the Acts of 1960, supersedes Section 5B of Chapter 111 as placed in the Generai iaws jy Cbepter 335 of the Acts of 2055 , as amended by Chapter 495 of the Acts of ?966. 
Page 27.

Nothing in this section shall prevent the departmeat of labor and findustries from establishing rules and regulations for the protection of the bealti end safety of employees against lonlzing radiation in any place of employnent as deflned in section one of ciapter one hundred and forty-nine. Said departirent of labor and industries shail consult with the department o: public health at leest thistJ days prior to tie adootion or modilicaiion of any rules or regulations insofar as they pertain to the bealth aspects of ionizing radiation. The department of public bealtb shall aporove, modify, or aisapprove all proposed rules and regulations of political subdivisions of the comomealth insofar as they pertain to the bealth aspects of lonizing radiation and no such rules and regulations which do not have the aporoval of tibe department shall be adopted.

Approved August $30,1960$. 
THE COMMONWEALTH OF MASSACHUSETTS

$\begin{array}{ccc}\text { Advance CODY } & 1980 & \text { Acts and Resolves } \\ \text { MLCHAEL JOSEPH CONNOLIY, State Secretary }\end{array}$

Chap. 474. REIATING TO THE REGISTRATION OE SOURCES OF NONIONIZING RADIATION.

Be it enacted, etc., as follows:

Chapter 111 of the General Laws is hereby amended by striking out section 5B, as most recently amended by section 15 of chapter 443 of the acts of 1970, and inserting in place thereof the following section:-

Section 5B. The deparment may require registration of sources of lonizing and nonionizing radiation and shall, from time to time, after a public hearing, prescribe and establish rules and regulations to control the radiation hazards of radioactive materials and of machines which emit ionizing and nonionizing radiation for the purpose of protecting the general public and individuals against hazards associated with the use, transportation, storage, packaging, sale, distribution, production and disposal thereof. Such rules and regulations shall not limit the kind and amount of radiation that may be intentionally administered by a person licensed to so administer radiation under the laws of the commonwealth. Such rules and regulations shall be filed with the state secretary at least thirty days prior to their effective date and shall become effectve thirty days thereafter unless a later effective date is specified by the deparment. Whoever violates any such rule or regulation shall be punished by a fine of not less than ten nor more than fifty dollars. Whoever, after due notice, continues to violate any such rule or regulation shall be punished by a fine of not less than one hundred dollars nor more than five hundred dollars to the use of the commonwealth for each offense. Each day of such violation after such notice shall constitute a separate offense. The supreme judicial court or superior court, upon application of the department, or upon application of any party interested, with the approval of the department, may enforce such rules and regulations, and restrain the use or occupation of premises or such portion thereof as the department may specifiy untl such rules and regulations have been complied with.

Nothing in this sectlon shall prevent the department of labor and industries from establishing rules and regulations for the protection of the health and safety of employees against ionizing radiation in any place of employment as defined in section one of chapter one hundred and forty-nine. Said department of labor and industries shall consult with the department of public health at least thirty days prior to the adoption or modification of any rules or regulations insofar as they pertain to the health aspects of ionizing and nonionizing radiation. 
57

COMOMONWEALIY OF MLASSACHUSETTS

DEPARTMENT OF PUBLIC WORKS

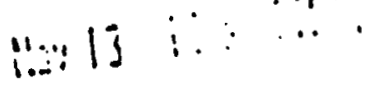

HAIARDOUS MAIERIALS REGULAIIONS

TITLE 720 SECTION 8.00

(CODE OF MASSACIUSETTS REGULATIONS)

\section{SECTION 8.01 Purgose}

These regulations prescribe the requifements of the Massachusetrs Department of Public Works (hereinafier the Department) governing the transportation of hazardous materials is commerte on srate inighways. The fegularions are adopted to establish comprehensive regularion of the shipping, packaging, marking, laosling, placarding, handing and trassportation of hazardous materials in commeree. They aro established in order to protcer the general public, their lives and theis property in a manner consistent with the regularions issued by the United Stares Departmen of Transportarion. The regulations apply to alI common, contract and private carriers and shippers of hazardous nate:i=ls being tramsported in commerce over stare highways.

\section{SECTIO:: 2.02 Scope}

(i) The regulations adopted hereiz shall be applicable as state soujations to common, contract and privare carriers and to shippers when they transport hazardous materials in inirasiate commerce, interstate comerce or both over Massachusetts stare hi ghways. 
58

(2) The regulations adopted herein shall apply to all motor vehicles transporting hazarcious materials in commerce on Massuchuscte. state highways. The regulation shall apply whether the hazardous material is being transported as a cargo or part of a cargo.

(3) Whenever the term "interstate" is used in the Federal rogulations adopted herein it shall, for the purpose of these regulations, mean and include both interstate and intrastate transportation in commerce on Massachusetts state highways.

(4) Whenever the term "state highway" is used in these regulations it shall include all so-called railroad bridges transferred to the Department in accordance with Chapter 634 of the Acts of 1971. Saje tridges are made state highirays by Chapter 92 of the Acts of 1978 .

\section{SECTION 8.03 Adoption and Incorooration of Federal Regulations as State Regulations.}

Parts 171, 172, 173, 177, 178 and 179 of Title 49, Chapter 1, Code of Federal Regulations, revised as of October 1, 1977, are hereby a'opted as the Department's regulations governing the transportation of hazardous materials upon the state highways of Massachusetts, subject to the exceptions provided in Section 8.05 . Said Parts of Iitle 49 are hereby incorporated by reference into these regulations and they shall be subject to the explanations and modifications provided herein.

No person shall offer, accept or transport a hazardous material in commerce on Massachusets state highways unless the material is properly classed, described, packaged, narked, labelled, landled, placarded and in proper condition for shipment in accordance with these regulations. 


\section{9}

SECIION 8.04 Determination of Unsafe Materials und Substancos.

iazardous materials and substances as defined in ellosc regulations and the regulations incorporated herein are hercby declared to be unsafe materials and substances. They shall not ixo transported on state higiways unless the material or substance is properly classed, described, packaged, narked, labelled, landled, placarded and in proper condition for shipment as required hy these regularions.

SECTION 8.05 Portion of Federal Regulations Exeluded from Adodtion.

The following requirements of Parts 171, 172, 173, 177, 178 and 179 of the Feriers regulations are exeluded and sot adopted by the Departrent :

(i) Any gortion of the Federal regulations governing trans. portation of hazardous materials by air, water, rail or pipelize, and

(ii) Any portion of the Federal regulations governing or requiring the reporting of hazardous material incidents, including, our not ! tritedta, Section 171.15 and 171.16 .

SECIION 8.06 Federal Exemprtons.

ifilinut the necessity of further action or ease-by-case sevicw on its part, the Department hereby accepts the validity of any exemption or renewal thereof issued by the United States Department of Transportation under Section 107, Subpart 3 of Title 49. Any person operating under a current, valid exemption or rencwal thercos under said Section 107 shall be deemed to be in compliance with those 
portions of these regulations to which the exemption applics, pro vided that the person is complying with the rerms of the cxcmption.

SECIION 8.07 Cargo Tank Vehicles - Retail Delivery of Fuel oil.

(a) Cargo tank rehicles engaged in the retail delivery of fucl oil shall be exempted from the shipping paper requirements containcd in Section 172, Subpart C.

(b) Cargo tank vehicles engaged in the retail delivery of fucl oil shall comply with the placarding requirements contained in Section 172, provided however that prior to September 1, 1980 , - the rale shall not apply to any such cargo task with block lettcred "Flaunirele" placards or markings in accordance with fire Prevention Regulation 7, Section $4(e)$ of the Massachusetts Board of Fire Prerention Regulations.

SECTION 8.08 Penalty for Violation of these State Regulations.

The penaliy for violation of the regulations adopted herein shall be those contained in the provisions of Massachusetrs General Laws Chapter 85 Section 28 and Chapter 90 Section $31 \mathrm{~A}$ and any other applicable state Iaw. Each violation shall be treated separately. When the viblation is a continuing one, each day of the violation constitures a separate offense.

SECTION 8.09 Conflict with other State Regulations.

These regulations establish minimum standards which must be complied with in conjunction with the transportation of hazardous materials. Therefore, in the event of a conflict between this regulation and any other state regulation, the stricter, more stringent standard shall apply and govern. 
SECTION S.10 Amendment.

These riles and regulations may be amended from time to timc in accordance with the applicable provisions of Massaciusetrs Gineral Law Cinaper jOA.

SECTION 8.11 Severability.

If any provision or clause of these regulations to any pcrson or circumstance is beld invalid, such invalidity shall not affect other provisions or applisasions of tine regulation which can be given effect without the iavalid provision or application. To this ead the provisions of this regulation are declared to be severable.

\section{SECTION 8.12 Waivez}

Tilese rules and regulations or any portion or portions thercof may be waived by the Department if after consideration of the facts involved it is determined that a particular situation warents such waiver.

SECTIC:: S.13 -EsEActive Dare.

These rules and regulations shall take effect on the date they are filot wistine Secteray of the Comonwealih and shall remain in effect unili repealed, replaced or amended by other rules anc reguiations.

AUTHORITY: M.G.I. C. 6 , s. $91(4)$, C. 85, S: 2, C. 85, S. 2B, C. 85, S. $2 E$, C. 90, S. $32 \mathrm{~A}$. 
- IN WITNESS WIIEREOF the following duly authorizcd Officcrs have caused these rules and regulations to bc approved and adopted as rules and regulations of the Massachusetts Departmont of Public Works at a duly convened meeting of the Public works Commission of the Massachusetts Departsent of Publice Works held on Noviember 8,1978 .

A true copy attest:

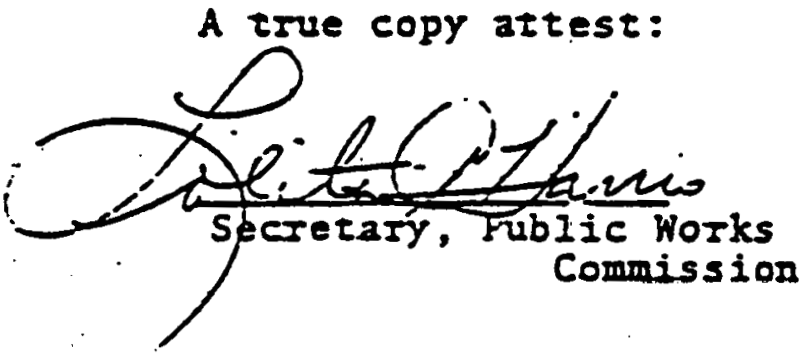

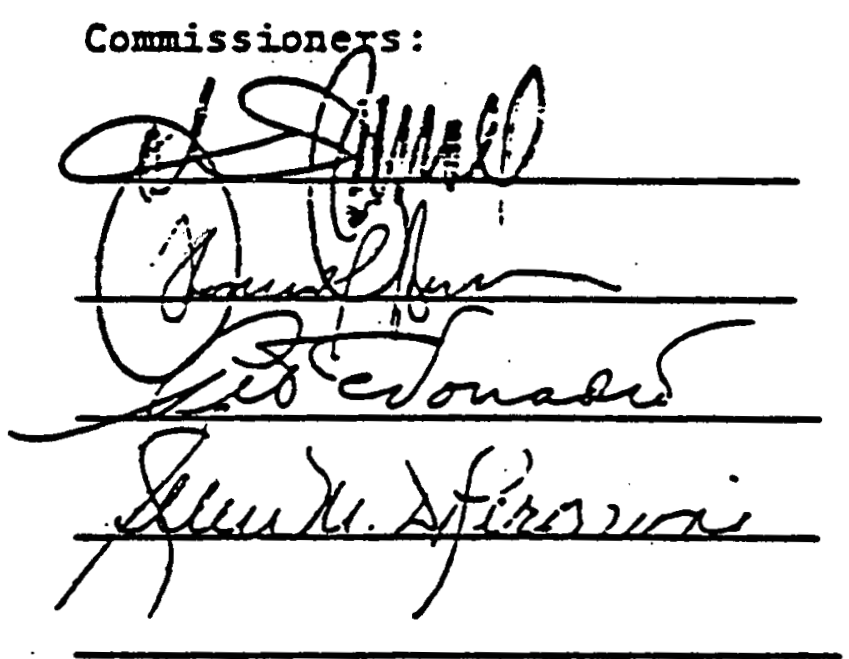




\section{MASSACHUSETTS}

Massachusetts Turnpike Authority

Suite 3000, Prudential Center

Boston, Massochusetts 02199

Radioactive shipments are allowed to move, under permit, on the Massachusetts Turnpike. Transportation of radiaactive materials are prohibited from travel through the Callohon and Sumner Tunnels.

Source: Compendium of Regulations - Shipments of Rodiocctive Materials over Toll Roods, Bridges and Tunnels - February 1974 - Compiled by: Intemational Bridge, Tunnel \& Turnpike Association, Inc. 


\author{
Massochusetts Port Authority \\ Administration Building \\ Charlestown, Massachusetts 02129 \\ Maurice J. Tobin Memorial Bridge
}

Radioactive shipments are allowed to travel on the Maurice Tobin Bridge, provided they conform to the applicable regulations of the Atomic Energy Commission, the United States Department of Transportation and the Interstate Commerce Commission.

Source: Compendium of Regulations - Shipments of Radioactive Materials over Toll Roods, Bridges and Tunnels - February 1974 - Compiied by: International Bridge, Tunnel \& Turnpike Association, Inc. 
APPENDIX D: ROSTER OF DAILY NEWSPAPERS IN MASSACHUSETTS 


\author{
AMHERST (D3) Hampshire County \\ AMHERST MORNING RECORD .............. Ind. \\ 109 Mairi Street \\ Amherst. MA 01002 \\ 413-256-8331 \\ Circulates in Amherst and Northern Hampshire. Southern \\ Franklin Counties. \\ Day of Pub \\ Circulation \\ Printed \\ Daily (AM), No Sat. \\ 5,008 PO $(9 / 30 / 79)$ \\ Adv. Deadline \\ Adv. Rate PCl \\ Adv. Page Size \\ Adv. Col. Width \\ Wire Services \\ Own Mag. \\ Published \\ 3 PM day betore publication \\ \$2.10/Comm./Comb. \\ $8 \mathrm{col} \times 21$ " \\ $91 / 2$ picas $/ 101 / 2$ picas \\ UPI \\ Focus \\ Friday \\ Content: Weekend entertainment guide with full week TV listing \\ $\&$ calendar of local cultural events. \\ Special Editions: Welcome Back (College Students): 1: Bridal \\ Section: 2; Create an Ad: 2; House Hunter: 3. 4.5: Graduation \\ Section: 6; Summer Fun: 7; Welcome Students: 9; Newcomers: \\ 10; Christmas: 11, 12
}

\section{ATHOL (F2) Worcester County}

ATHOL DAILY NEWS

225 Exchange Street

Athol. MA 0133

617-249-3535

Circulates in Athol, Orange, Warwick, Erving, Wendell, New Salem, Royalston, Phillipston. Petersham.

$\begin{array}{ll}\text { Publication } & \text { Daily (PM). Saturday (AM) } \\ \text { Circulation } & 5.449 \text { PO }(9 / 30 / 79) \\ \text { Printed } & \text { Offset } \\ \text { Press Rel. Deadline } & 24 \mathrm{hrs} \text {. betore pub. } \\ \text { Adv. Deadline } & 24 \mathrm{hrs} \text { before pub. } \\ \text { Adv. Rate PCI } & \text { S2.20 } \\ \text { Adv. Page Size } & 8 \mathrm{col} \times 21 " \\ \text { Adv. Col. Width } & 11 \text { picas/113/4 picas } \\ \text { Wire Services } & \text { AP: UPI } \\ \text { Own Mag. } & \text { TV Guide } \\ \text { Published } & \text { Saturday } \\ \text { Content: TV listings \& News. }\end{array}$

\section{ATTLEBORO (J5) Bristol County}

THE SUN CHRONICLE $\ldots \ldots \ldots \ldots \ldots \ldots \ldots$ Rep... Ind. 34. South Main Street

Attleboro. MA. 02703

$617-222-7000$

Circulates in Attleboro, Foxboro. Mansficld. Norfolk. North Attlehoro. Norton, Plainville, Rehoboth. Wrentham. Seekonk.

Publication Daily (PM), Saturday (AM)

Circulation

Printed

$22,475 \mathrm{PO}(12 / 79)$

Adv. Deadline

Adv. Rate PCI

Adv. Page Size

24 hrs. before pub.

48 hrs. before pub.

S3.36/Comb

$8 \mathrm{col} \times 21$ "

$101 / 2$ picas $/ 11.25$ picas

Wire Services UPI: Christian Science Monitor

Own Mag.

Published

TV Log'Showtime

Saturday

Content: Week's listings of TV: features both local \& network. television programming, \& movies, music.

Special Editione: Washington's Birthday Aulo: 2; Bridal: 3; Leisure: 5. 11; Back 10 School: 8; Football: 9; Home Impruveinent: 10.

\section{BEVERLY (L2) Essex County}

THE BEVERLY TIMES

Dunham Road

Beverly. MA 01915

617-922-1234

Circulates in Beverly, Boxford, Danvers, Hamilton, Ipswich, Tops: field. Wenham, Manchester.

Publication

Circulation

Printed

Press Rel. Deadline

Adv. Deadline

Adv. Rate PCI

Adv. Page Size

Adv. Col. Width

Wire Services

Own Mags.

Published

Content: Weekly calendar of events: leature stories, classitied and Weekend Calendar.

Special Editions: Strvival: 1: Auto: 2: Wedding \& Outdoor: 3:

Home Garden: Real Estate: Diving: 4: Guide to North Shore: 6

Back to School: 8: Football 8 Home Improvement: 9: Car Care

Real Estate \& New Car Care: 10: Cook Book: 11

Essex County Newspaper Group

\section{BOSTON (K3) Suffolk County}

BOSTONGLOBE ........................ Ind

135 Morrissey Boulevard

Boston, MA 02107

617-929-2000; Telex: 94-6374 (General): Telex: 94-0980 (Edito rial): TWX: 710-333-0294 (Advertising)

Circulates throughout New England

Publication

Circulation

Printed

Press Rel. Deadline

Adv. Oeadline

Adv. Rate PCI

Adv. Page Size

Col. Width

Wire Services

Daily (All Day Newspaper).

482,578 ABC (9/30/79)

DiLitho

$24 \mathrm{hrs}$. before pub.

$48 \mathrm{hrs}$. before pub.

$\$ 51.80 /$ Comm./Comb.

9 col. $\times 223 / 4^{\prime \prime}$

9.6 picas/10 picas

AP: UPI: Reuter: Knight-Ridder; Washin ton Post - Los Angeles Times; Data Fe ture: Dow Jones

Special Editions: Sections planned only four months before pub cation; call for intormation.

BOSTON HERALD AMERICAN. In

300 Harrison Avenue

Boston. MA 02106

617-426-3000

Circulates throughout New England

Publication Daily (AM)

Circulation 277.819 ABC (3/31/79)

Printed

Press Rel. Deadline

Adv. Deadline

Adv. Rate PCl

Adv. Page Size

Adv. Col. Width

l.etierpress

$24 \mathrm{hrs}$. before pub.

$24 \mathrm{hrs}$. belore pub.

$\$ 28.42 /$ Comb

9 col. $\times 21 "$

Wire Services

9.9 picas $/ 10$ picas

New York Times; AP: UPI

Special Editions: Brides: 2: Home Furnishings: 2: Home and G den: 4. Red Sox 4: Cookbook: 11. 


\section{BOSTON (cont'd)}

THE CHRISTIAN SCIENCE MONITOR ............ Ind.

One Norway Street

Boston, MA 02115

617-262-2300: Telex: 94-0589/94-0590

Circulates throughout New England. the United States and the world.

Publication

Circulation

Printed

Press Rel. Deadline

Adv. Deadline

Adv. Rate PCI

Adv. Page Size

Adv. Col. Width

Wire Services

Own Mag.

Published

Content: Ads \& News

\author{
Daily (AM). no Sat. \\ 174,300 ABC $(10 / 1 / 79)$ \\ Olisel \\ $24 \mathrm{hrs}$. belore pub. \\ $48 \mathrm{hrs}$ before pub. \\ $\$ 23.10$ (N.E. Rate)/Comm \\ $6 \mathrm{col} . \times 149 / 32 "$ (tab) \\ 10.2 picas $/ 12.2$ picas \\ UPI: Reuters \\ The Regional Edition \\ Friday - New England
}

Special Editions: Midwinter Vacation: 1; Food: 2; Spring Fashion 2: International Travel: 3: Switzerland: 3; Fed. Republic of Germany: 3: Home Improvement: 3: British Isles: 4: Canada: 4: Arts \& Antiques: 4; Automotive: 4: Summer vacation: 5; Summer Fashion: 5: Summer Entertainment: 6: Summer Food: 6: Home Furnishings: 7: Fall Food: 8: Fall Fashion: 9; International Travel (Cruise Section: 9; Arts \& Crafts: 9; Banking \& Saving: 10; Automotive: 10; Holiday Food: 10; Winter Vacation: 11; Savings for Retirement: 11.

\section{BROCKTON (K4) Plymouth County}

\section{BROCKTON DAILY EVENING ENTERPRISE AND}

TIMES $\ldots \ldots \ldots \ldots \ldots \ldots \ldots \ldots \ldots \ldots$ Ind

60 Main Street

Brockton, MA 02403

617-586-6200

Circulates throughout Plymouth County, Avon, Easton, Holbrook.

Randolph, Stoughton. Raynham. Taunton, Lakeville, Norton. Mansfield Abington. Bridgewater, Carver, Duxbury, East Bridgewater, Halifax. Manover, Hanson, Kingston. Marshfield. Middleboro Norwell. Pembroke. Plymplon, Rockland, Wareham. West Bridgewater, Whitman

Publication

Circulation

$$
\text { Daily (PM) }
$$

Printed

0.491 ABC (12/79)

Press Rel. Deadline

Adv. Deadline

Adv. Rate PCl

Adv. Page Size

Adv. Col. Width

Wire Services

Synd. Mag.

Letterpress

31 hro. bofore pul.

$72 \mathrm{hrs}$. belore pub.

$\$ 6.45$

col. $\times 21^{\prime \prime}$

9.9 picas $/ 10.5$ picas

AP: UPI

Family Weekly

Special Editions: Business \& Banking Review: 1: Valentine's Day: 2. Washington's Birthday: 2: Bride's Section: 3: Car Care Tab: 4 Home Improvement \& Outdoor Living: 5: Back to School: 8 Back 10 School Safety: 8: Football Tab: 9; Fall \& Winter Car Care Section: 9; 1980 Fall Festival Auto Section: 11; Christmas Greetings: 12.

\section{CHELSEA (K3) Suffolk County}

CHELSEA RECORD ....................... Ind

270 Broadway

Chelsea, MA 02150

617-884-2416

Circulates in Chelsea.

Publication

Circulation

Printed

Daily (PM), no Sat.

Press Rel. Deadline

Adv. Deadline

Adv. Rate PCI

Adv. Page Size

Adv. Col. Wioth

Wire Services

Special Editions: Vacation: Summer; Washington's Birthday: 2

\section{CLINTON (H3) Worcester County}

THE CLINTON DAILY ITEM ...................... Ind.

156 Church Street

Clinton, MA 01510

617-368-0176

Circulation

Printed

Press Rel. Deadline

Adv. Deadline

Adv. Rate $\mathrm{PCl}$

Adv. Page Size

Adv. Col. Width

Wire Services

4.190 paid, PO: 75 Free, PO (10/9/79)

Oifset

$24 \mathrm{hrs}$. before pub.

$24 \mathrm{hrs}$. before pub.

$\$ 2.05 /$ Comb.

8 col. $\times 21^{\prime \prime}$

11 picas $/ 12$ picas

UPI

Special Editions: Car Care: Fall, Spring: Bridal: 1, 6: Home Improvement: 4, 9; Back to School: 8; Christmas Edition: 12. Coulter Press Group

\section{DEDHAM (K4) Norfolk County}

DAILYTRANSCRIPT Ind.

420 Washington Street

Dedham, MA 02026

617-329-5000

Circulates in Dedham. Needham, Norwood. Westwood.

Publication Daily (PM), no Sat

Circulation $\quad 11,019$ ABC $(9 / 30 / 79)$

Printed Olfset

Press Rel. Deadline $24 \mathrm{hrs}$. before pub.

Adv. Deadline $\quad 48 \mathrm{hrs}$. before pub.

Adv. Rate PCl $\$ 6.16$ /Comm./Comb.

Adv. Page Size $9 \mathrm{col} \times 21^{\prime \prime}$

Adv. Col. Width $\quad 9.5$ picas $/ 10.5$ picas

Wire Services UP

Special Editions: Bride \& Groom: 2; Auto Dealer's Open House: 2; Spring Fashion: 3; Newcomer's Magazine: 3; Real Estate Preview: 4: Better Living: 4: Bride \& Groom: 5; Flag Code: 6: Better Living: 9; Business \& Industry Review: 10; Holiday Magazine: 11.

Transcript Newspaper Group

\section{FALL RIVER (K6) Bristol County}

FALL RIVER HERALD NEWS $\ldots \ldots \ldots \ldots \ldots \ldots$ Ind. 207 Pocasset Street

Fall River. MA 02722

617-676-8211

Circulates in Fall River, Freetown. Somerset. Swansea. Westport. Little Compton (RI), Portsmouth (RI), Tiverton (RI).

\section{Publication Daily (PM)}

Circulation $\quad 41.495 \mathrm{ABC}(10 / 79)$

Printed

Press Rel. Deadline $24 \mathrm{hrs}$. before pub.

Adv. Deadline 72 hrs. before pub.

Adv. Rate PCI

Adv. Page Size

Adv. Col. Width

Wire Services

Synd. Mag.

$\$ 4.34$

$8 \mathrm{col} . \times 223 / 4 "$

10 picas 111 picas

New York Times News Service

Family Weekly

Special Editions: Bride: 2; Industrial: 3: Home \& Garden: 5; Automotive: 5,11

\section{FITCHBURG (G2) Worcester County}

FITCHBURG-LEOMINSTER SENTINEL

\& ENTERPRISE $\ldots \ldots \ldots \ldots \ldots \ldots \ldots \ldots \ldots \ldots$. Ind

808 Main Street

Fitchburg. MA 01420

617-343-6911

Circulates in Fitchburg. Leominsler. Ashburnham. Ashby. Ayer. Groton Lunenburg. Shirley, Sterling. Townsend, Westminster. Greenvilte (NH). New Ipswich (NH).

Publication

Circulation

Printed

Press Rel. Deadline

Adv. Deadline

Adv. Rate PCI

Adv. Page Size

Adv. Col Width

Wire Services

Daily (PM)

24,404 ABC $(12 / 31 / 78)$

Offset

24 hrs. before pub.

$72 \mathrm{hrs}$. belore pub.

$\$ 3.82$

$8 \mathrm{col} \times 211 / 2^{\prime \prime}$

10 picas $/ 10$ picas 10 points AP

Special Editions: Progress Edition: 1: Bride's Section: 2: Spring Summer Car Care: 3; Home Improvement: 3, 9; Cookbook: 10 


\section{FRAMINGHAM (J3) Middlesex County}

THE MIDDLESEX NEWS ......................... Ind.

33 New York Avenue

Framingham. MA 01701

617-872-4321

Circulates in Framingham, Acton. Ashland, Bellingham, Boxborough, Concord. Franklin, Holliston. Hopkinton. Hudson, LexingIon. Lincoln. Marlboro. Maynard, Medfield. Medway, Milford, Millis. Northboro. Sherborn. Southboro, Stow. Sudbury. Waltham. Wayland. Westboro, Weston, Upton. Hopedale. Mendon.

Publication Daily (PM). Sat. (AM)

Circulation

Printed 51.050 ABC $(12 / 15 / 79)$

$24 \mathrm{hrs}$. before pub.

Adv. Deadline

Adv. Rate PCl

Adv. Page Size

Adv. Col. Width

Wire Services

72 hrs before pub.

$\$ 7.35$

9 col. $\times 21 "$

9.9 picas $/ 10.5$ picas

AP: UPI: Christian Science Monitor

Special Editions: Bride's: 1, 2; Financial: 3; Fashion: 4.

\section{GARDNER (G2) Worcester County}

THE GARDNER NEWS $\ldots \ldots \ldots \ldots \ldots \ldots \ldots \ldots$ Ind. 309 Central Street

Gardner, MA 01440

617-632-8000

Circulates in Gardner, Ashburnham, Baldwinville. East Templeton, Hubbardston, Otter River. Templeton, Westminster, Winchendon.

Publication

Circulation

Printed

Press Rel. Deadline

Adv. Deadline

Adv. Rate PCI

Adv. Page Size

Adv. Col. Width

Wire Services

Daily (PM)

7.684 ABC $(6 / 30 / 79)$

Offset

Morning of pub

$24 \mathrm{hrs}$, before pub.

$\$ 3.00 /$ Comm.

$8 \mathrm{col} \times 211 / 2 "$

$101 / 2$ picas $/ 111 / 4$ picas AP

C. Auto Care: 6. Back to School: 8

Christmas Guide: 12: Christmas Greetings: 12

\section{GLOUCESTER (M2) Essex County}

THE GLOUCESTER DAILY TIMES ............. Ind.

Whittemore Street

Gloucester. MA 01930

617-283-7000

Circulates in Gloucester, Essex. Manchester, Rockport.

Publication

Circulation

Printed

Daily (PM). Sat. (AM)

Press Rel. Deadline

Adv. Deadline

Adv. Rate PCI

Adv. Page Size

Adv. Col Width

Wire Services

Own Mags.

Published

Oifsel

$48 \mathrm{hrs}$. before pub.

$\$ 3.70 /$ Comb

8 col. $\times 21$ "

11 picas/ 11.5 picas

UPI

Calendar/Cape Ann Summer Sun Saturday'Friday

Content: Weekly Calend ties, restaurants, touring.

Special Editions: Survival: 1. Auto: 2. Wedding: 3: Outdoor: 3 : Home \& Garden: 4: Real Estate: 4: Dining: 4: Guide to North Shore: 6: Back to School: 8: Football: 9: Fall Home Improvement: 9: Car Care: 10: Real Estate: 10: New Car Care: 10: Cook. book: 11

Essex County Newspaper Group

\section{GREENFIELD (D2) Franklin County}

GREENFIELDRECORDER $\ldots \ldots \ldots \ldots \ldots \ldots \ldots$ Ind

14 Hope Street

Greenfield. MA 01301

413-772-0261

Circulates throughout Franklin County. Amherst. Hinsdale (NH). Winchester (NH). Vernon (VT)

Publication Daily (PM). Sat. (AM)

Circulation

Printed

15.286 ABC $(9 / 30 / 79)$

Press Rel. Deadline 24 hrs, before pub.

Adv. Deadline

Adv. Rate PCI

Adv. Page Size

Adv. Col. Width

Wire Services

$24 \mathrm{hrs}$. before pub.
$48 \mathrm{hrs}$. before pub.

$\$ 3.50 / \mathrm{Comm} / \mathrm{Comb}$.

$8 \mathrm{col} \times 213 / 8^{\prime \prime}$

9.6 picas $/ 10$ picas AP

Special Editions: Bridal Section: 1: Auto Section: 2; Cookbook: 3: Home \& Garden: 4: Summer '80: 5; Back to School: 8: Fall Sports: 9; Fall Home Improvement: 10: Christmas Section: 11: Winter Section: 12

\section{HANOVER (L4) Plymouth County}

SOUTH SHORE NEWSDAY ................ Ind. One Mayflower Drive

Hanover, MA 02339

617-878-1111

Circulates in Hanover, Rockland. Pembroke. Hanson, Abington. Norwell, Marshfield, Kingston.

$\begin{array}{ll}\text { Publication } & \text { Daily (PM). No Sat. } \\ \text { Circulation } & 3,842 \text { PD (10/79) } \\ \text { Printed } & \text { Offset } \\ \text { Press Rel. Deadline } & 48 \mathrm{hrs} \text { prior to pub. } \\ \text { Adv. Deadline } & 24 \mathrm{hrs} \text { prior to pub } \\ \text { Adv. Rate PCI } & \$ 3.00 / \text { Comm./Comb. } \\ \text { Adv. Page Size } & 9 \mathrm{col} \times 21^{\circ} \\ \text { Adv. Col. Width } & 91 / 2 \text { picas/10 1/2 picas } \\ \text { Wire Services } & \text { UPI } \\ \text { Special Editions: Spring Gardening: 4: Summer }\end{array}$

Special Editions: Spring Gardening: 4; Summer Sign Post: 6: Back to School: 8: Home Improvement Energy Saving: 9; Wedding: 10: Auto Buying Guide: 10; Christmas: 11. Franklin Publishing Group

\section{HAVERHILL (K1) Essex County}

HAVERHILL GAZETTE ......................... Ind. 447 West Lowell Avenue

Haverhill, MA 01830

617-374-0321

Circulates in Haverhill. Amesbury, Georgetown, Groveland Merrimac. Newburyport. West Newbury, Salisbury. Atkinson (NH). Brentwood (NH). Danville (NH). Exeter (NH). Fremont (NH). Newton (NH). Plaistow (NH). Seabrook (NH). Epping (NH). Raymond $(\mathrm{NH})$, Hampton (NH). North Hampton $(\mathrm{NH})$.

Publication

Circulation

Printed

Press Rel Deadline

$\begin{array}{ll}\text { Press Rel. Deadline } & 24 \mathrm{hrs} \text {. belore pub. } \\ \text { Adv. Deadline } & 72 \mathrm{hrs} \text {. before pub. }\end{array}$

Adv. Rate PCl

Adv. Page Size

Adv. Col. Width

Wire Services

$$
\text { Daily (PM). Sat. (AM) }
$$$$
\text { 19.570 ABC (7/79) }
$$

Offset

54.55

$8 \mathrm{col} \times 211 / 2 "$

10.6 picas $/ 11.6$ picas UPI

Wusiness \& Finance: 1: Washingtons Birthday New Car: 2 . Bridal: 2. Design \& Ady. 4 . Progress 1ssue 4 . Sports Tab: 4: Real Estate: 4: Mother's Day: 5; Outdoors: 5: Vacation Auto Guide: 6: Real Estate Guide: 7: Back To School: 8: Home Improvement-Energy: 9: Car Care: 9: Cooking School. 10: Now Car Announcement: 10: Cookbook: 11: Christmas Special is. sue: 12: Gift Guide (daily): 11: 12. 


\section{HOLYOKE (D4) Hampden County}

TRANSCRIPT-TELEGRAM ................. Ind. 120 Whiting Farms Road

Holyoke. MA 01040

413-536-2300

Circulates in Holyoke. Belchertown. Chicopee. Easthampton, Granby. South Hadley. Southampton

Publication Daily (PM). Sat. (AM)

Circulation 29.590 ABC (9/30/79)

Printed Offset

Press Rel. Deadline $24 \mathrm{hrs}$, before pub.

Adv. Deadline $48 \mathrm{hrs}$. before pub.

Adv. Rate PCl $\$ 4.25$

Adv. Page Size $\quad 8 \mathrm{col} \times 211 / 2^{\prime \prime}$

Adv.Col. Width $\quad 11$ picas $/ 11.5$ picas

Wire Services

Own Mag.

Published

AP: UPI

TV

Content: TV listings.

Special Editions: Bridal: 1: Profiles: 2: Washington's Birthday Automotive Section: 2: Spring Fashion: 3: Spring Car Care: 3 Spring Home Improvement: 4; Vacation \& Travel: 5; Profiles: 6

Back to School: 8: Fall Home Improvement Care: 9: Fall Car Care: 9; New Car: 10; Design an Ad: 10; Christmas: 11.

\section{HUDSON (H3) Middlesex County}

THE HUDSON DAILY SUN ................ ind. 16 Washington Street

Hudson, MA 01749

617-562-5200

Circulates in Hudson, Berlin, Bollon, Maynard, Stow, Sudbury.

Publication

Circulation

Printed

Daily (PM)

2.634 ABC (9/79)

Adv. Rate PCI

Adv. Page Size

Adv, Col. Width

Wire Services

$48 \mathrm{hrs}$. before pub.

$\$ 2.50 /$ Comm./Comb.

8 col. $\times 21 "$

11 picas $/ 12$ picas

UP

Special Editions: Annual Business Review: 1: Spring Auto Buyers Guide: 3; Fall Auto Buyers' Guide: 10.

Enterprise Sun Publications Group

\section{HYANNIS (N6) Barnstable County}

CAPE COD TIMES ........................n.

319 Main Street

Hyannis. MA 0260

617-775-1200

Circulates in Barnstable. Bourne. Brewster. Chatham. Dennis, Eastham. Falmouth, Harwich. Hyannis. Masnpee. Orleans. Provincetown. Sandwich, Truro. Wellifleet. Wareham, Yarmouth. Nantucket. Martha's Vineyard.

Publication

Circulation

Printed

Piess Ret. Deadline

Adv. Deadline

Adv. Rate PCl

Adv. Page Size

Adv. Col. Widen

Wire Services

Daily (PM). Sat. (AM)
34.294 ABC (9/79)

Offset

$24 \mathrm{hrs}$. before pub.

$48 \mathrm{hrs}$, before pub.

$\$ 4.95$

8 col. $\times 21^{\prime \prime}$

9.2 picas $/ 10.2$ picas

Los Angeles Times: Washington Post: New York Times: Ottaway News Service; UPI"

Special Editions: Tax Tips: 1: Create an Ad Contest: 2: Cookbook:

3: Home Improvement: 4: Summer Preview: 5; Back to School

8: Financial Planning: 9; Fall Auto: 10: United Fund: 10: Early

Christmas: 11: Christmas Gift Guide: 11: Christmas Story Book: 12.

Ollaway Newspapers, Inc. (NY)

\section{LAWRENCE (K2) Essex County}

LAWRENCE EAGLE-TRIBUNE Ind. P.O. BOX 100

Lawrence, MA 01842

617-685-1000. Telecopier: 685-1588

Circulates in Lawrence. Andover, Georgetown. Groveland, Methuen. Middleton, Newbury, North Andover, North Reading. Reading. Atkinson (NH), Londonderry (NH), Pelham (NH). Windham $(N H)$. Salem $(N H)$. Derry $(N H)$. Plaistow $(N H)$.

Publication Daily (PM)

Circulation $\quad 51.811$ PD $(9 / 30 / 79)$

Printed

Press Rel. Deadline $24 \mathrm{hrs}$. before pub.

Adv. Deadline $\quad 48 \mathrm{hrs}$. before pub.

Adv Rate PCI

Adv. Page Size

Adv. Col. Width

Wire Services

$\$ 6.10 /$ Comb.

9 col $\times 211 / 4^{\prime \prime}$

9.6 picas $/ 9.75$ picas UP

Special Editions: Accent on Finances: 1: Accent on Brides: 2 . Automotive Section: 2; Washington's Birthday: 2; Fashion: 3; Accent on New Season: 4: Progress Edition: 4: Accent on House and Garden: 5; Accent on Summer: 6: Accent on Brides: 7: Energy Section: 8: Back to School: 8: Home Improvement: 9; Restaurant and Dining Guide: 10; Holiday Cook Book: 11: Gift Guides: 12; Real Estate Tab: Spring-Summer-Fall.

\section{LOWELL (J2) Middlesex County}

THE SUN ................................. Ind. 15 Kearney Stree

Lowell, MA 01852

617-458-7100; Telex: 94-7493

Circulates in Lowell. Acton, Ayer, Bedford, Billerica, Boxborough, Burlington, Carlisle, Chelmsiord. Concord. Dracut, Dunstable, Groton, Harvard, Littleton, Maynard, Pepperell, Tewskbury, Shirley, Townsend, Tyngsboro. Westford. Wilmington.

Publication Daily (PM)

Circulation 56.045 ABC (12/31/79)

Printed Dilitho

Press Rel. Deadline $24 \mathrm{hrs}$. before pub.

Adv. Deadiline $\quad 48 \mathrm{hrs}$. before pub.

Adv. Rate PCl $\$ 6.45 /$ Comb.

Adv. Page Size 9 col. $\times 211 / 2 "$

Adv. Col. Widin $\quad 9$ picas $/ 10$ picas

Wire Services AR: UNI

Special Editions: Financial Review: 1; Valentine's Day: 2: Automobile Section: 2: Bridal: 3; Frozen Food Section: 3: Home Improvement: 3; Spring Real Estate Review: 4: Greater Lowell Chamber of Commerce Section: 5: Truck Section: 6: Salute to Westford, Chelmsford: 6: Salute 10 Littleton. Ayer: 6: Salute to Pelham. NH. Nashua, NH: 7: Salute to Billerica, Tewksbury: 7: Salute to Tyngsboro: 7: Interior Fashions: 8: Teachers Announcements: 8, 9; Fall Car Care: 9: Restaurant Guide: 10: Shopping Around: 10: Industrial In Review: 11: Foolball: 11: Christmas Gift Guide: 12: Christmas Church Page: 12.

\section{LYNN (L3) Essex County}

DAILY EVENING ITEM

38 Exchange Street

Lynn, MA 01903

617-593-7700

Circulates in Lynn. Lynnfield. Marblehead. Nahant. Peabody, Revere, Salem, Saugus. Swampscott. Chelsea. Winthrop.

Publication

Circulation

Printed

Press Rel. Deadline

Adv. Deadline

Adv. Rate PCI

Adv. Page Size

Adv. Col. Width

Wire Services

\section{Daily (PM) \\ $30.663 \mathrm{ABC}(3 / 79)$}

Letterpress

24 hrs. before pub.

$48 \mathrm{hrs}$. before pub.

$\$ 8.50 /$ Comb

$8 \mathrm{col} \times 211 / 4^{\prime \prime}$

10.6 picas $/ 11.3$ picas UPI

Special Editions: Autos: 2: Business Profiles: 2: Brides: 3; Home \& Garden: 4: Car Care: 4. 10; Restaurant Guide: 6; Restaurant Guide: 11. 


\section{MALDEN (K3) Middlesex County}

MALDENEVENINGNEWS .................... Ind.

277 Commercial Sireet

Malden. MA 02148

617-321-8000

Circulates in Malden. Everett, Medford. Melrose.

Publication Daily (PM), no Sat.

Circulation $\quad 9,339$ paid. CAC: 1.861 non-paid, CAC

Printed $\quad(1 / 79)$

Press Rel. Deadline 12 hrs. before pub.

Adv. Deadline $\quad 48 \mathrm{hrs}$. before pub.

Adv. Rate PCl \$3.90/Comm./Comb.

Adv. Page Size 8 col. $\times 21$ "

Adv. Col. Width 11 picas $/ 12$ picas

Wire Services UP

Special Editions: Business Review: 1 Washington's Birthday: 2

Spring Spectacular: 3: Dining Guide: 4: Sidewalk Sale: 6: 7 :

Back to School: 8: Fall Festival Football: 9: Dining Guide: 10;

Thanksgiving Football: 11; Christmas Carol Song Book: 12.

3M Nelwork Group

\section{MARLBORO (H3) Middlesex County}

MARLBOROENTERPRISE ....................... Ind

250 Maple Strebt

Marlboro. MA 01752

$617-481-5441$

Circulates in Mariboro. Northboro. Southboro.

Publication Daily (PM)

Circulation $\quad 4.449 P D(9 / 79)$

Printed Otiset

Press Rel. Deadline 24 hrs. betore pub

Adv. Deadline $48 \mathrm{hrs}$. belore pub.

Adv. Rate PCl $\quad \$ 2.50 /$ Comm./Comb.

Adv. Page Size $8 \mathrm{col} \times 211 / 2^{\prime \prime}$

Adv. Col. Width 11 picas $/ 12$ picas

Wire Services UPI

Special Editions: Annual Business Review: 1: Spring Auto Buyers

Guide: 3: Fall Auto Buyers Guide: 10.

Enterprise Sun Publications Group

\section{MEDFORD (K3) Middlesex County}

MEDFORD DAILY MERCURY ................

Zero Governors Avenue

Medford. MA 02155

$617-321-8000$

Circulates in Medford, Arlington. Malden. Somerville. Winchester. Publication Daily (PM), no Sat.

Circulation $\quad 7.042$ paid. CAC: 1.658 non-paid. CAC Printed (1/79)

Press Rel. Deadline 12 hrs. before pub.

Adv. Deadline $48 \mathrm{hrs}$. before pub.

Adv. Hăle PCl \$3.60/Comm/Comb.

Adv. Page Size $8 \mathrm{col} \times 21^{\prime \prime}$

Adv. Col. Width 11 picas/12 picas

Wire Services UP

Special Editions: Business Review: 1: Washington's Birthday: 2:

Spring Spectacular: 3: Dining Guide: 4: Sidewalk Sale: 6, 7:

Back 1o School: 8: Fall Festival: 9: Footbalt: 9: Dining Guide: 10 :

Thanksgiving: 11: Football: 11: Christmas Carol Song Book: 12 3M Network Group

\section{MELROSE (K3) Middlesex County}

MELROSE EVENING NEWS ....................Ind.

414 Main Street

Melrose. MA 02176

617-321-8000

Circulates in Melrose. Saugus, Wakefield.

Publication Daily (PM), no Sat.

Circulation 2.161 paid. CAC: 1.439 non-paid, CAC

Printed

Press Rel. Deadline 12 hrs. before pub.

Adv. Deadine $48 \mathrm{hrs}$. before pub.

Adv. Rate $\mathrm{PCl} \quad \$ 2.75 /$ Comm./Comb.

Adv. Page Size $8 \mathrm{col} \times 21^{\prime \prime}$

Adv. Col. Width 11 picas/12 picas

Wire Services UPI

Special Editions: Business Review: 1: Washington's Birthday: 2:

Spring Spectacular: 3. Dining Guide: 4. Sidewalk Sale: 6: 7 :

Back to School 8; Fall Festival: 9; Football: 9: Dining Guide: 10:

Thanksgiving: 11; Football: 11: Christmas Carol Song Book: 12. $3 \mathrm{M}$ Nelwork Group

\section{MILFORD (H4) Worcester County}

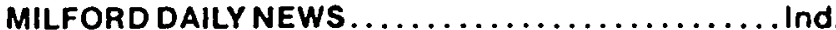

159 S. Main Stree

Millord, MA 01757

617-473-1111

Circulates in Milford, Bellingham, Franklin. Holliston. Hopedale.

Hopkinton. Medfield. Medway, Mendon. Millis. Upton. Uxbridge.

Northbridge, Ashland.

Publication

Circulation

Printed

Daily (PM)

Press Rel Deadline Oitset

Adv. Deadline

Adv. Rate PCI

Adv. Page Size

Adv. Cól. Width

Wire Services

Oifset

$24 \mathrm{hrs}$. before pub.

$48 \mathrm{hrs}$. before pub.

$\$ 3.65$

$9 \mathrm{col} \times 211 / 2$

9.08 picas $/ 10.08$ picas

Special Editions: Spring Bridal: 2: Spring Car Care: 3: Lawn \& Garden: 4: Fall Bridal: 9; Fall Car Care: 10.

Alta Group (ME)

\section{NEW BEDFORD (L6) Bristol County}

THE STANDARD-TIMES .nd.

555 Pleasant Street

New Bedford, MA 02742

617-997-7411

Circulates in New Bedford. Acushnet. Assonet. Buzzards Bay, Carver: Dartmouth. Fairhaven. Freetown. Lakeville, Marion. Mattapoisett. Middleboro. Rochester. Wareham, Westport.

Publication

Circulation

Printed

Daily (PM). Sat. (AM)

Adv. Deadline

Adv. Rate PCI

Adv. Page Size

Adv. Col. Width

Wire Services

24 hrs before pub.

72 hrs. before pub.

$\$ 7.31$

$6 \mathrm{col} \times 211 / 2$

12.4 picas/ 13.4 picas

AP: Dow Jones: Ottaway Newspapers: New York Times

Special Editions: Industrial Business Section: 2: Recipe Contest: 3. Home \& Garden: 4: Seaside: 6 : Bride Pictorial: 7: Back to School: 8: Today's Women: 9: Christmas Layaway: 11: Gift Guide: 12 . 


\section{NEWBURYPORT (L1) Essex County}

THE DAILY NEWS $\ldots \ldots \ldots \ldots \ldots \ldots \ldots \ldots$. Ind.

23 Liberty Street

Newburyport. MA 01950

617-462-6666

Circulates in Newburyoort. Amesbury, Merrimac. Newbury, Rowley. Salisbury. West Newbury. Seabrook (NH), Georgetown. Groveland.

Publication Daily (PM). Sat. (AM)

Circulation $\quad 10.210 \mathrm{ABC}(12 / 79)$

Printed Offset

Press Rel. Deadline $24 \mathrm{hrs}$. belore pub.

Adv. Deadline. $\quad 48 \mathrm{hrs}$ belore pub

Adv. Rate PCl $\$ 3.64 /$ Comm /Comb.

Adv. Page Size B col $\times 21$

Adv. Col. Width 11 picas/ 11.5 picas

Wire Services UPI

Own Mags. Calendar/North Shore

Published Saturday/Saturday

Content: Weekly Calendar of Events/Feature stories, classified. and weekend calendar.

Special Editions: Survival: 1: Auto: 2; Wedding: 3: Outdoor: 3; Home \& Garden: 4: Real Estate: 4: Dining: 4: Guide to North Shore: 6: Back to School: 8; Footbalt: 9: Fall Home Improvement: 9; Car Care: 10; Real Estate: 10; New Car Care: 10; Cookbook: ir.

Essex County Newspapers Group

\section{NORTH ADAMS (B2) Berkshire County}

THE TRANSCRIPT ...................... Ind.

124 American Legion Drive

North Adams. MA 02147

413-663-3741

Circulates in North Adams. Adams. Cheshire, Williamstown, Southwestern Vermont

Publication

Circulation

Printed

Press Rel. Deadline

Adv. Deadline

Adv. Rate PCl

Adv. Page Size

Adv. Col. Width

Wire Sorvioes

Special Editions: Bridal Section: 2: Home \& Garden: 4; Business Review: 4: Interiors: 11: Holiday Gilt Guide: 11 .

\section{NORTHAMPTON (D3) Hampshire} County

DAILY HAMPSHIRE GAZETTE ................. Ind.

115 Conz Street

Northampton. MA 01060

413-584-5000

Circulates throughout Hampshire County.

rublication Daily (PM). Sat. (AM)

Circulation

Printed

Press Rel. Deadline $24 \mathrm{hrs}$. before pub.

Adv. Deadline $48 \mathrm{hrs}$ before pub

Adv. Rate PCI

Adv. Page Size

Adv. Col. Width

Wire Services

Own Mag.

Published

12.967 paid, ABC: 114 Iree ABC (9/30/79)

Oifset

$\$ 4.00$

$6 \mathrm{col} \times 211 / 2$

AP $1 / 2$ picas $/ 131 / 2$ picas Cont

Special Editions: Bridal: 3 : Spring Fashions: 4 : Cookbook: 5 : Back to College: 8; Fall Fashions: 9; Christmas Gilt Guide: 11 :

$8 \mathrm{col}$. $\times 211 / 2$ "

10.9 picas $/ 11.5$ picas

AP

Hampshire Life

Salurday

\section{PEABODY (L2) Essex County}

THE DAILY PEABODY TIMES ............... Ind.

54 Main Street

Peabody, MA 01960

617-532-1005

Circulates in Peabody.

Publication

Circulation

Printed

Daily (PM). Saturday (AM)

$24 \mathrm{hrs}$ before pub.

Adv. Deadline $\quad 48 \mathrm{hrs}$. before pub.

Adv. Rate PCl $\$ 3.43 /$ Comm./Comb.

Adv. Page Size $8 \mathrm{col} \times 21^{\prime \prime}$

Adv. Col. Width 11 picas/11.5 picas

Wire Services UPI

Own Mags. Caldendar/North Shore

Published Saturday/Saturday

Content: Weekly Calendar of events/Feature stories, classified and weekend calendar.

Special Editions: Survival: 1; Auto: 2; Wedding: 3: Outdoor: 3

Home \& Garden: 4; Real Estate: 4; Dining: 4: Guide to Norll

Shore: 6: Back io School: B; Football: 9; Fall Home Improve

ment: 9: Car Care: 10: Real Estate: 10; New Car Care: 10: Coo

Book: 11.

Essex Counity Newspapers Group

\section{PITTSFIELD (A3) Berkshire County}

THE BERKSHIRE EAGLE . .................. Inc

33 Eagle Streel

Pittsfield. MA 01201

413-447-7311

Circulates in Pittsfield. Adams. North Adams. Williamstow! Cheshire, Dalton, Great Barrington. Hinsdale (NH), Lanesbr rough, Lee, Lenox, Richmond, Stockbridge, West Stockbridge

Publication Daily (AM)

Circulation $\quad 31.189$ paid. ABC; 315 free, ABC (9/30/7!

Printed Olfset

Press Rel. Deadline $24 \mathrm{hrs}$. before pub.

Adv. Deadline 4 PM, 4 days before pub.

Adv. Rate PCI $\quad \$ 5.50 /$ Comm./Comb.

Adv. Page Size $\quad 8 \mathrm{col} \times 211 / 4^{\prime \prime}$

Adv. Col. Width 11 picas/11.5 picas

Wire Services UPI: New York Times Wire Sorvioo

Speical Editions: Business \& Industry: 1: Washington's Birthdi Auto Section: 2; Spring Fashion Section: 4; Falt Fashion: 9: Di ing Guide: 10.

The Miller Newspapers Group

\section{QUINCY (K4) Norfolk County}

PATRIOT LEDGER .......................... In

13 Temple Street

Quincy, MA 02169

617-786-7000

Circulates in Quincy. Abington. Braintree. Canton. Cohass Dedham, Duxbury. Foxboro. Hanover, Hanson. Hingha Holbrook, Hull, Kingston. Marshfield. Milton. Needham. Norwe Norwood. Pembroke. Plymouth. Randolph, Rockland. Scitua Sharon, Stoughton, Walpole. Westwood. Weymouth, Whitman

Publication

Circulation

Printed

Adv. Rate PCl

Adv. Page Size

Adv. Col. Width

Wire Services

$$
\text { Daily (PM). Sat.(AM) }
$$

Letterpress

24 hrs. before pub.

48 hrs. before pub.

$\$ 10.50$

8 col. $\times 22 "$

10 picas, 8 points/11 picas AP

Special Editions: Economy Cars: 1: Washington's Birthday $N$ Car: 2: The Wedding: 3; Red Sox Warmup: 4; Spring Garden \& Home Improvement: 4: Leisure Living: 5: Summer Cookbo 6. Fall Fashions \& Back 10 School: 8: New England Patriots $h$ mup: 8; Energy in the BO's: 9; Home Furniture: 10; The Wedd 10: Winter Activities: 11; Holiday Cookbook: 11.

Mirror Communications Group 


\section{SALEM (L2 1/2) Essex County}

THE SALEM EVENING NEWS . Ind

155 Washington Street

Saleni. MA 01970

617-744-0600

Circulates in Salem, Beverly, Danvers, Hamilton, Ipswich, Marble-

mead. Middleton, Peabody, Swampscott, Topsfield, Wenham, Box-

Hord. Rowley, Georgetown

Publication Daily (PM)

Circulation 30.949 A

Press Rel Deadline $24 \mathrm{hrs}$ before pub.

Adv. Deadline $48 \mathrm{hrs}$. before pub.

Adv. Rate PCl

$\$ 9.35 /$ Comb

Adv Page Size $\quad 8 \mathrm{col} \times 21$

Adv. Col. Width

11 picas $/ 12$ picas

AP: UPI

Special Editions: Bridal: 2; Washington's Birthday: 2; Frozen

Food: 3. Industrial Review: 3. Fashion Forecast 3 ; Boating: 4 Home Improvement: 4: Car Care: 5 : Home Buyer's Guide: 5: Leisure Living: 6: Summer Returns: 6; Marblehead Race Week: 7 Heritage Days: 8; Football: 9; Home Improvements: 9; Fall Fashions:9. 100th Anniversary: 10: Car Care: 10: Cars 81: 10: Restaurant Section: it: Cuúkbooki 11; 3 Gift Guides: 12

\section{SOUTHBRIDGE (F4) Worcester County}

THENEWS .Ind.

25 Elm Street

Southbridge, MA 01550

617-764-4325

Circulates in Southbridge, Charlton, Sturbridge.

Publication . Daily (PM). Sat. (PM)

Circulation

Printed

$6.097 \mathrm{PO}(1 / 1 / 80)$

Offset

Press Rel Deadline $24 \mathrm{hrs}$. before pub.

Adv. Deadline $48 \mathrm{hrs}$. before pub.

Adv. Rate $\mathrm{PCl} \$ 3.80 / \mathrm{Comb}$

Adv. Page Size $\quad 8$ col $\times 21$ "

Adv. Col. Width $\quad 91 / 2$ picas/11 picas

Wire Services UPI

Own Mag.

Published

Worcester County

Thursday

Content: Fealure supplement.

Special Editions: Industrial \& Business Review: 2: Spring Fashion: 3: Home Improvement: 4: Fall Fashion: 9: Christmas Gift Guide

Worcester Counly Newspapers Group

\section{SPRINGFIELD (D4) Hampden County}

T

THE DAILY NEWS

.Dem

1060 Main Stre?

Springfield. MA 01101

413-788-1000

Circulates in Springfield. Adams. Agawam. Amherst, Belchertown. Chicopee. Dalton, Deerfield. East Longmeadow. Easthampton, Granby, Greenfield. Hadley, Hampton, Hatfield. Holyoke. Longmeadow. Ludlow. Monson. North Adams, Northampton. Palmer. Pittsfield. South Hadley. Southwick. Turners Falls Ware. West Springfield, Westfield, Wilbraham. Enfield (CT). Suffield (CT).

Publication

Circulation

Printed

Daily (PM)

76.706 ABC (3/31/79)

Press Rel. Deadline 24 hrs. before pub.

* Adv. Deadline

Adv. Rate $\mathrm{PCl}$

Adv. Page Size

24 hrs. before pub

3 days before pub.
$\$ 10.78$ in Comb.

9 col. $\times 211 / 2$

Adv. Col Width

8.25 picas $/ 8.625$ picas

Wire Services

UP: AP; New York. Times News Service

Newhouse Newswire: Chicago Daily

News: Washington Post - Los Angeles Times

Special Editions: Annual Business Review-Forecast: 1, Bride \& Groom: 3: Frozen Food Festival: 3: Spring Spruce-Up: 4: Finan cial Planning and Your Future: 4: Outdoor Living \& Summer Vacation: 5 ; Western MA Football: 8: Furniture-Home Furnishings \& You: 10.

Newhouse Group (NY)

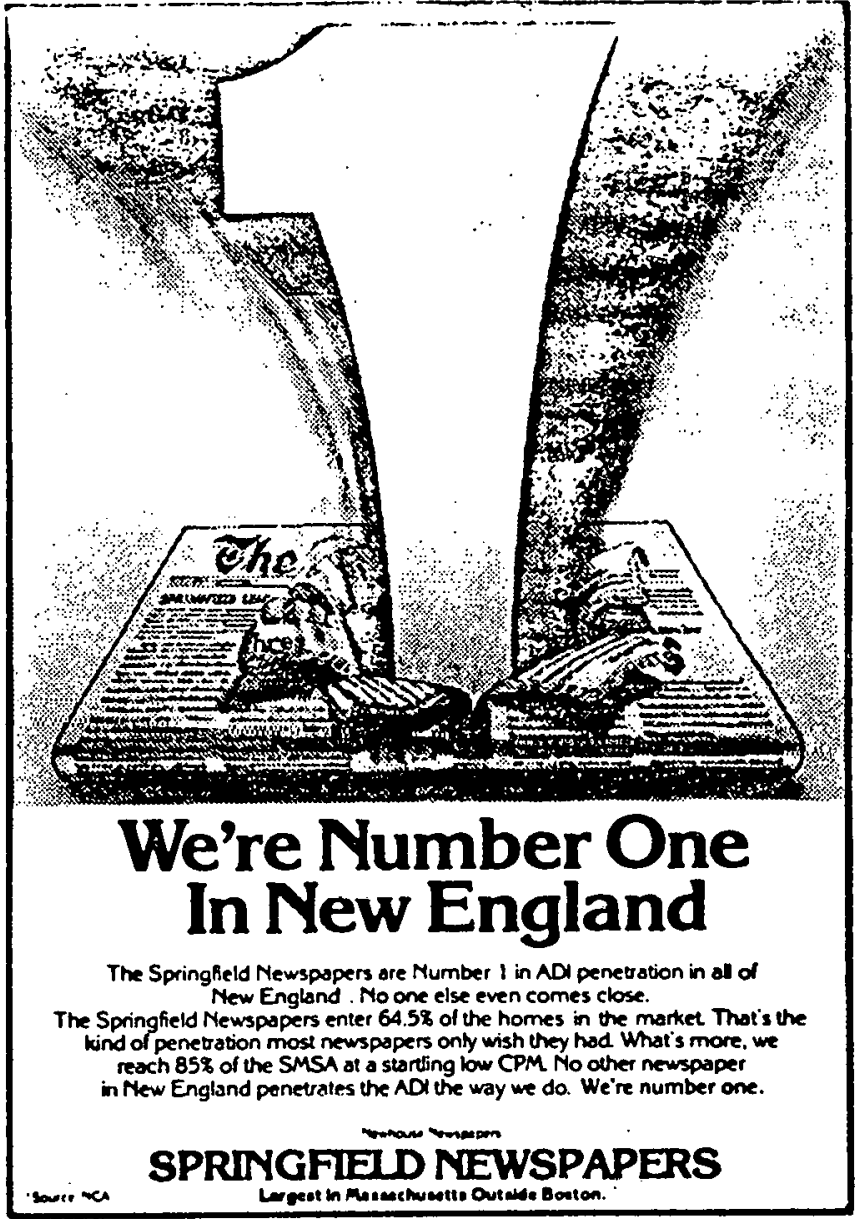

\section{Updated for you}

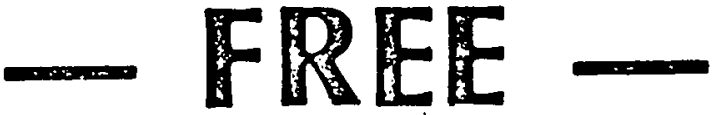

Once a year, approximately 6 months from date of publication, you'll be brought up to date with all the latest additions, deletions or corrections for your directory. You'll receive this information automatically. That way, year-round, you'll have the most accurate media source available ... prepared by people who are specialists in this area.

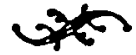




\section{SPRINGFIELD (cont'd)}

THE MORNING UNION. Ind.

1860 Main Street

Springlield. MA 01101

413-788-1000

Circulates in Springlield, Adams, Agawam, Amherst. Belcherlown. Chicopee, Dallon, Deerfield. East Longmeadow. Easthampton. Granby. Greenfield. Hadley, Hampton, Hatfield. Holyoke. Longmeadow. Ludlow, Monson, North Adams. NorthampIon, Palmer. Pittsfield. South Hadley. Southwick. Turners Falls. Ware, West Springfield, Westfield. Wilbraham, Enfield (CT). Suflield (CT)

Publication

Circulation

Printed

Press Rel. Deadline

Adv. Deadline

Adv. Rate PCI

Adv. Page Size

Adv. Col. Width

Wire Services

Daily (AM)

73,684 ABC (3/31/79)

Dilitho

24 hrs. before pub.

4 days before pub.

$\$ 10.78$ in Comb.

9 col. $\times 211 / 2$

8.25 picas $/ 8.625$ picas

UPI: AP: New York Times News Service:

Chicago Daily News: Washington Post Los Angeles Times: Newhouse Newswire

Special Editions: Annual Business Review-Forecast: 1: Bride \& Groom: 3: Frozen Food Festival: 3: Spring Spruce-Up: 4; Financial Planning and Your Future: 4: Outdoor Living \& Summer Vacation: 5: Western MA Football: 8: Furniture-Home Furnishings 8 You: 10 .

Newhouse Group (NY)

\section{TAUNTON (K5) Bristol County}

TAUNTON DAILY GAZETTE ................ Ind.

5-9 Cohannel Street

Taunion. MA 02780

617-822-7121

Circulates in Taunton, Berkley. Dighton, Lakeville, Middleboro, Norton. Raynham. Rehoboth.

Day of Pub

Circulation

Daily (PM)

Printed Olfset

Press Rel. Deadline $24 \mathrm{hrs}$, before pub.

Adv. Deadline $48 \mathrm{hrs}$. before pub.

Adv. Rate PCl \$3.08/Comm./Comb.

Adv. Page Size $8 \mathrm{col} \times 21^{\prime \prime}$

Adv. Col. Width $\quad 9.9$ picas $/ 11$ picas

Wire Services IIPI

Special Editions: Bridal Supplement:1: Progress Edition: 2; Outdoor Recreation: 6: Cookbook: varies-8 or 10: Back To School:

8: Fall Fix-Up: 9: Christmas Shopping Guide: 11

\section{WAKEFIELD (K2 1/2) Middlesex County}

THE WAKEFIELD DAILYITEM Rep.

26 AlbIOn Street

Wakefield. MA 01880

617-245-0080

Circulates in Wakefield. Lynnfield. Melrose. Reading. Stoneham. Publication

Circulation

Printed

Press Rel. Deadline

Adv. Deadline

Adv. Rate PCl

Adv. Page Size

Adv. Col. Width

Wire Services

Daily (PM). no Sal.

6.605 paid. PO: 90 , free, $P O(10 / 12 / 79)$

Offset

$24 \mathrm{hrs}$. belore pub.

24 hrs. before pub.

\$2.75/Comb.

8 col. $\times 21$

$101 / 2$ picas $/ 111 / 2$ picas

UPI

Arial Editions: Washington's Birthday Auto Issue. 2. Spring Has

Arrived: 3: Car Care Issue: 4: Home Improvement Issue: 5 : July

4th Issue: 7: Football Preview Issue: 8; Football, 1980 (High

School Sports): 9; Christmas Gift-Guide: 12.

Wakefieio Daily liem Group

\section{WALTHAM (J3) Middlesex County}

NEWS-TRIBUNE Ind

18 Pine Street

Waltham. MA 02154

617-893-1670

Circulates in Waltham. Belmont. Newton. Watertown. Weston.

Publication

Circulation

Printed

Press Rel. Deadline

Adv. Deadline

Adv. Rate PCl

Adv. Page Size

Adv. Col. Width

Wire Services

Daily (PM), no Sat.

13,756 ABC (9/30/79)

Offset

24 hrs. before pub.

48 hrs. before pub.

$\$ 4.76 /$ Comm./Comb.

$9 \mathrm{col} \times 21^{\prime \prime}$

9.5 picas $/ 10.5$ picas U.5PI

Special Editions: Bride \& Groom: 2; Auto Dealer's Open House: 2 Spring Fashion: 3: Newcomer's Magazine: 3: Real Estate Preview: 4: Bride \& Groom: 5; Flag Code: 6: Better Living: 9; Business \& Industry Review: 10; Holiday Magazine: 11.

Transcript Newspapers Group

\section{WEST SPRINGFIELD (D4) Hampden County}

WEST SPRINGFIELD NEWS Ind

62 School Stre日

Westfield, MA 01085

413-562-4181

Circulates in West Springfield, Westfield, Blandford. Chester. Granville, Huntington, Montgomery, Russell, Southwick.

Publication

Circulation

Printed

Daily (PM), Sat. (AM)

Press Rel. Deadline

Adv. Deadline

Adv. Rate $\mathbf{P C l}$

Adv. Page Size

Adv. Col. Width

Wire Services

Own Mags.

Published Unavallable Offset

$12 \mathrm{hrs}$. before pub.

24 hrs. before pub. $\$ 2.50 /$ Comm./Comb.

8 col. $\times 21$ "

9.5 picas $/ 10.5$ picas

UPI

Food Guide/ Wheels Wednesday/Friday

Content: Homemaking supplement/Automotive information.

Special Editions: Business \& Industry Revipw: 1; Goorge Wasl " ingtuı Auiu Section: 2; Bride's Guide: 5; Home Improvement: 9.

\section{WESTFIELD (C4) Hampden County}

WESTFIELD EVENING NEWS ................... Ind.

62-64 School Street

Westfield, MA 01086

413-562-4181

Circulates in Westfield, Blandford, Chester, Granville, Huntington. Montgomery, Russell, Southwick.

Publication

Circulation

Printed

Press Rel Deadline $24 \mathrm{hrs}$ before pub.

Adv. Deadline $24 \mathrm{hrs}$. before pub.

Adv. Rate PCl $\$ 2.50 /$ Comb

Adv. Page Size $\quad 8 \mathrm{col} \times 21^{\prime \prime}$

Adv. Col Width 9 picas $/ 10.5$ picas

Own Mags. Food Guide/Wheels

Published Wednesday/Friday

Content: Homemaking supplement/automotive information.

Special Editions: Business \& industry Review: 1: George Washington Auto Section: 2; Bride's Guide: 5: Home Improvement: 9. 


\section{WOBURN (K3) Middlesex County}

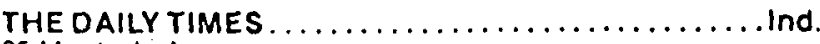
25 Montvale Avenue

Woburn MA 01801

617-933-3700

Circulates in Woburn. Burlington, Winchester.

Publication Daily (PM), no Sat.

Circulation $\quad 11.741$ CAC (6/30/79)

Printed

Press Rel. Deadline $24 \mathrm{hrs}$. before pub.

Adv. Deadline $24 \mathrm{hrs}$. before pub.

Adv. Rale PCl $\$ 2.94 /$ Comm./Comb.

Adv. Page Size 9 col. $\times 21 "$

Adv. Col. Width. $\quad 9.9$ picas $/ 10.4$ picas

Wire Services UP

Own Mag.

Published

Middlesex East

Wednesday

Content: All news covering 9 surrounding communities.

\section{WORCESTER (G3) Worcester County.}

EVENING GAZETTE ....................... ind.

20 Franklin Street

Worcester, MA 01613

617-755-4321; Telecopier: 617-757-2275 (Classified Adv. Dept.)

Circulates throughout Worcester County.

Publication

Circulation

Printed

Daily (PM)

88.732 ABC $(9 / 30 / 79)$

Letterpress

$24 \mathrm{hrs}$. betore pub.

Adv. Deadline $\quad 48 \mathrm{hrs}$. before pub.

Adv. Rate PCl. $\quad \$ 20.30 /$ Comm./Comb.

Adv. Page Size $\quad 9 \mathrm{col} \times 211 / 2^{\prime \prime}$

Adv. Col. Width $\quad 9.9$ picas $/ 11.4$ picas

Wire Services AP. UP

Special Editions: Business Review: 1: Bridal Issue: 1. 9; Spring Fashion Show: 2: George Washington's Aulo Section: 2: Home Improvements: 2; Engineering: 2: Beauly: 3: Energy: 3; Baseball: 5: Travel: 5; Football: 8; Fall Fashion Show: 9; Easketball: 10: Fall Auto Preview: 11.

\section{WORCESTER (cont'd)}

WORCESTERTELEGRAM .

20 Franklin Street

ind.

Worcester MA 01613

617-755-4321; Telecopier: 617-757-2275 (Classified Adv. Depl.)

Circulates throughout Worcester County.

Publication

Circulation

Printed

Press Rel. Deadline

Adv. Deadline

Adv. Rate PCI

Adv. Page Size

Adv. Col. Width

Daily (AM)

55.643 PO (9/30/79)

Letterpress

24 hrs. before pub.

48 hrs. before pub.

\$13.85/Comm./Comb.

9 col. $\times 211 / 2$

Wire Services

AP: UPI

Special Editions: See Evening Gazette (above) 
By lobert Cooke

Globe Stafl

HOUSTON - One of these days it's roing to be so nice' to have finally some good, clean, simple answers to the ques. thori of radiation hazard.

But not yet; so don't hold your breath. Helix, sit back, watch the fuss for awhile, ind try to keep an open mind. For opepiers, you might bone up a bit on the art ine science of statistics.

Some answers, of course, are being iffered, but they're awfully tough to mató sense of. For example:

穴

One gang - made ap of environmentillats, a lew doctors, scientists and hangers-on - insists with evangelistic tervor that all radiation, from chest

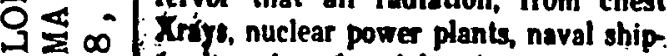
J $\sum \infty$ funde and nuclear laboratories, is worse. $z=-2$ thin inyone ever imagined and is causing

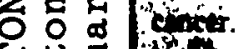

the other gang - consisting of the nuof clexis industry, some government agenElemi othèr scientists and equads of public rollitions experts - goes oround saying. is cintnce: "There, there, it's not as bad as all thit."

3 Sothewhere, still lost in the middle, is fol knth. When it will be found remains inf incertain.

* Xilt present much of the argument re. trotvei around an ultrecontroversial yearcold document knowe os the Mancuse Ifoth, which its suthors say shows that workts at the US Department of Eneryots buge resebrch center at Hanford. Wishig are experiencing higher cancer ritat than they should.

Copponente wy the ropart doesp'l show

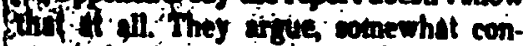
vincingly, that a sample of 25,000 workers at Hanford is far too small, and so the conclusion is invalid.

What then, de we really know ahout the dangers of low-level radiation?

First, most specialists are convinced that radiation at any level is not good for you. New emphassis is being placed on pyoiding Xrays II they're not absolutely. necessary, and ditto for other forms : radiation

Second, whether you can feel if or not all or us are being irradiated all the tim a low levers: by cosmic rays from space by particles from the sun and by radia fion Irom rocks. This means we've lived with radiation for a lone time without serious damare. Toe, il is vell-known that there are some natural mechanisms in the body to repair such damaze.

Third, even though the hazards of high levels of radiation are rather precisely known, much more research is necessary if we're to sort out the effects of tiny amounts of radiation among all the other ailments that plague man.

Ancording to Dr. Charles Land, from the National Cancer Institute, righi now "we probably know more about the carcl nogenic (cancer-causing) effects of ionizing radiation than we do about any other environmental carcinogen." The information about the hazards of high doses, indeed, is solid.

"The argument," he said to tbout en:study. Otherwise, statistical analysis ould be too weak for confisence.

The authors of the Mancuso Report George Kneale, Thomas F.Mancuso and Alice Stewart - contend their sample of 35,000 nuclear loboratory workers at Hanford is ample, that they can get some results that are believable.

Indeed, their claim basically, is that there is an effect 10 times greater than expected and the environmental groups say standards for exposure to radiation should thus be onetenth what they, are. At present, the allowed occupational exi cosure is 5 rads a year.

Stewart, who became controveridail in England for iher study of the effecte of Xrays on unborn babies, sald during a symposium at the annual meeting of the American.Assn. for the Advancement of Sciehce:

"Well, here we are, we've found the cisk. There is a basic fault in the whole idea of a linear hypothesis. II has a basic fault built into it from begin'ning.

"I maintain that until you had a popu. Jation of workers in the nuclear industry to study, no one in the world had a good study."

She was referring to the fact that most of the data on radiation hazard stems from studies of Japanese victims of the bombing of Hiroshima and Nagasaki in Work war it: She contended that other trapolating to low doses, and io do atvd wlinentsicelated to the bomb blast tendies of the elfects of low dowe tequinte "sample sizes that are Imprictleilly large." that if youries

This means, he said, that if yourie romg to study the effects of one rod (i) measure of radiation) on health, you'd need one million or mose penple in the ed to cover up the cancers caused by the radiation, so that hazard is not really. known accurately.

Epidemiologists - the scientisti wo specialist in finding out how diseaces spread through populations - have found that it's very difficult to select out oll of the so-called variables that are important. in cancer and radiation.

In shipyard workers, for example, itis not adequate to just count cancer yeathe among workers who wiere involved with huclear power systems. Other fattor, tuch as exposure to asbestos or othet toxic hiterials, are also important. It's also limpbettint so check for accuracy of cuncer diagndafi to compare similar populátions and to detetmine what kinds of tumion the vicutini died ol.

At Hinford for example, the ayerall; death rites from cancen, would be mis: leading if compired traten in the areas, because of what if khown in the "healthy worker" effect. the wotilti at: Hantord tend to be healthlet that the' general population outside exen in terms of cancer incidence. - because they are hired in part on the basis of good health. receive good health care and are clotely monitored.

For this reason, it's unwise to compare Hanford workers with those in the lifher. al population. They don't imatch. . it: 


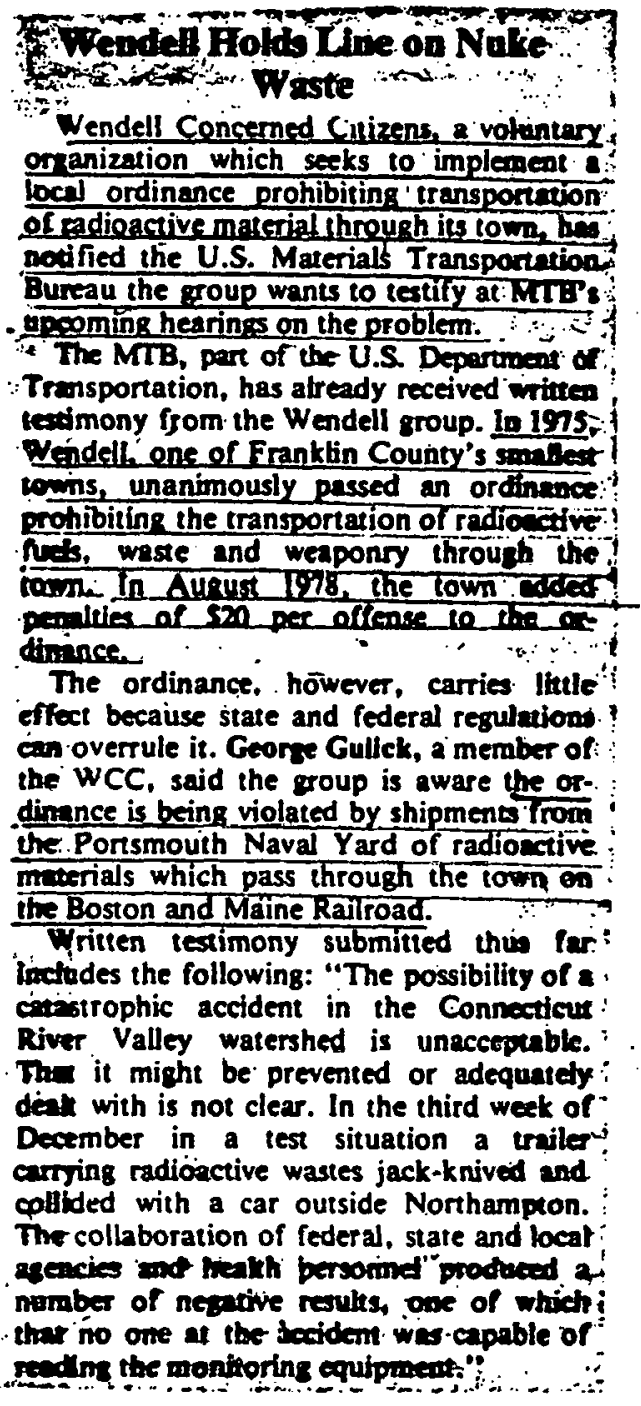


Sout.:.:.idien:

Daily Ner:s

Framinghen, Miz.

D. 45.000

is

SOUTH MIDDLESEX
DAILY NEWS

FEB $\& 1979$ E

Farmingham, MA

Expert

Ne:-

February 9, 1979

will speak on

$\therefore$

\section{radiation}

STOW - In an effort to allay fears and answer technical questions con$\therefore$-cerning microwave radiation the 10-

$\because$ cal Board of Health has invited an

$\rightarrow$ expert from the State Department of

1 Public Health to lead a forum on the subect.

$\therefore$ Al Comproni, from the division of

- v. radiation control, is expected to speak

- Feb. 12 at 7:30 p.m. in the Center School Auditorium.

$\therefore$ Accordling to the health board's sec$\because$ retary, Florence Chandler, members

$\because$ of the "Cltizens for the Protection of

$\therefore$ Stow" will be contacted and urged to attend.

The proup was organized to block: construction ol Radant Systems, Inc. $\therefore$ because of blological dangers feared

$\therefore$ Irom microwave radiation wheh

$\because$ enitted from the on-site testing of i- Sadar antennas.

$\therefore$ The company has proposed the congituction of a three million dollar bullding off kudson Road. -

Comproni was an invited guest at the Health board's regular meeting last Thestay and agreed to come before the town with technical data.

The bulling inspectior Is on the verge of fiving site plan approval to the company pending a legal interpre

tation of an exdsting bylaw bannis radiation trom structures in town.

: "Citizens for the Protection of Stow"

$\therefore$ have threatened a court sult against

. The townli the bylaw is lenored.

t:

$r$. Radant officials have promised to operate on less than one microwatt power but fearful cittzens are saying not enough is known about long term effects to allowit.

The group has initiated a legal fund and retained a lawyer to help them bblock construction of the company. They have aleo appenled to the state iDepartment of Environmental Quallty Engineering for protection. 


\section{U.S. Study Asks Caution On Low-Level Radiation}

Speciel to The Now Yort Tines"

WASEINGTON, Feb. 27- The Carter Administration advised Americans today to be wran ol exposing themselves to low evels of radiation but shied away trom seang to Impose stricter standards on Permissitoleamounts.

Joseph A. Califano Jr., the Secretary of Beaith; Education and Welfare, released

"working papers" prepared by the White Bouse Radiation Interagency Task Force on lonizing Radiation and stressed that more scientific research was needed to settle the issue of hazard.

An increasine number of critiss of Enderal adiation policy have comiended that perroissible levels of radlation expoonre have been set at to. hish a level thus endunsering the health of boith the eneral public and rorkes in the nuclear incuistry

"We do not belleve that the science is idequate to justify urther reductions," Mr. Califano told a news conference at Mis departmental headquarters.

Furber Discussion Sought

The working papers, which do not catry' the weighe of governmental back. tris but are intended to provoke discusston, propose such actions as setting ouddelines that would make it easier for a auclear worker claining radiation injury to fle a damage suit, expanding research into radiation hazards, and widening pubMe information efforts to warn the public of overexposing themselves to X-rays and the llke.

The draft report must be reviewed by other Federal agencies before finally Deing sent to the President who ordered the review last May.

Mr. Califano, whose department was deaigoed by President Carter as the coordinating group for the radiation study croup, directed the Food and Drug Adininistration to expedite guidelines for medical and dental procedures that lead to "promiscuous exposure to radiation."

The Secretary noted that the increased popularity of such devices as so-called CAT scanners, which employ lowilevel radiation for more complete X-rays of the body, is an example of potentially increased bazards.

"I an directing Dr. Donald Kennedy, C.mmisotoner of the Food and DruB Adininistratson, to accelerate F.D.A.'s efforts to reduce umecessary exposure to

radiation from the use of X-ray and puclear medicine procedures," he sald.

Mr. Callifano also said that a departmental study of persons present at the "Smoky" atomic test conducted in Utah 22 years ago had suggested "a higher than normal incidence of leukemia."

While imperfectly defined, the term 10\%-level radiation generally is applied to doses of one rem or less. The term rem itsell is an acronym lor koentren Equvalent Man with mentgen being a stardard. unit of radiation exposure. An ordinary chest $X$-ray delivers from 20 to 500 mill. rems.

About hall the radioactivity to which people are exposed stems froin naturar sources in rocks and sediments and trom such effects as cosmic rays from outer space. Collectively. this is called bectground radiation and varies between so and 200 millirems per person per year. depending upon geography. The medical eftects of both high and low level rediafon may include a variesy of differene forms of cancer, including leukemia.

ine secreta'y noted that research programs dealing with the hazards of radioactivity both to the public in general as well as in speciflc occupations would tate at least a year to be assembled.

"The lone-range health atfers ol expo sure to low-leyel ionizing cadiation consti. ate a serious public heglth isque." Mr: Califano said addine "ne must also remember the benefits society derives rom the use of radiation."

\section{- Eckchardt Plans U.S. Inquiry}

WASHINGTON, Feb. 27 (AP) - Representative Bob Eckhardt, Democrat of Texas said today that his Subcommittee on Oversight and Investigations would begin a "tull-scale investjgation toto all phases of radlation healeh dangers:"

Mr. Eckhardt, who held a news conference with Representatives Gunn Mckay of Utah and Jim Santini of Nevada, also Democrats, said the inquiry would tocus on the cancer deaths that might be associated with testing at the Nevada test site during the 1950's and 1960's.

The hearings will also look into the poessibility that people are now belng exporad

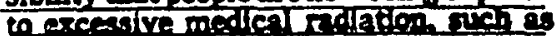
$X$-rave and to harge radiation doces in the wortsplace, Mr. Eckhandt said 
DAILY NEW HAMPSHIRE GAZETTE

Nor thhampton, MA

February $28, \quad i \cdot 79$

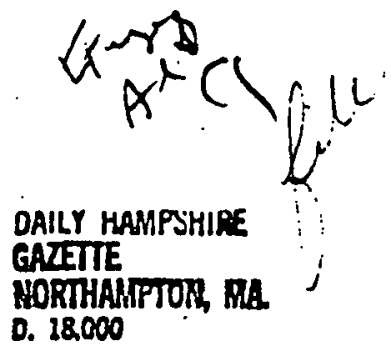

FEB 281979

Englinid

Nerpori:

Radiation hazard here
downplayed by state

Vehicles carrying low-level aminated with radiation during kind of material could be radiagctive. Waste which pass the operation of nuclear power within live miles of some 30 pants.

Western Masssachusetts corn- These materials carried on dangerous if the cask containing the material spilled open.

munities - inclnaling tulcks are not dangemus in the

Northampton and Amherst - event of most accidents said a pose no danger according to the state Department of Public state Department of Public Health radiation scientist. Used, or spent. fuel rods are piling up at many nuclear power plants because the federal government has not decided how to dispose of them.

Health.

A truck would bave to burn

The federal Department of une Finersy Policy Informa- within a bullding, creating tion Center in Boston yesterday poisonous fumes, betore it would relepend a report stating that pose a danger to people, he said some 250 New bngland com critics of nuclear power have munifesare whin tive miles of often expressed concern about 2 rand or which radioactive the shipment of high-level wastes are trapsported. radloactive waste, such as used Most of the shipmeats are of fuel rods, on public highways. Iow-level. wastes, suct as They fear an accident involvclothing and equioment.con: ing a vehicle containing that

Energy Monday issued a report naming five proposed temporary storage sites for spent fuel. One was identified as "Greentield".

However, energy department officials said the name designated an undetermined site and was not the Greenfield in clothing and equipment. 
Noriticin

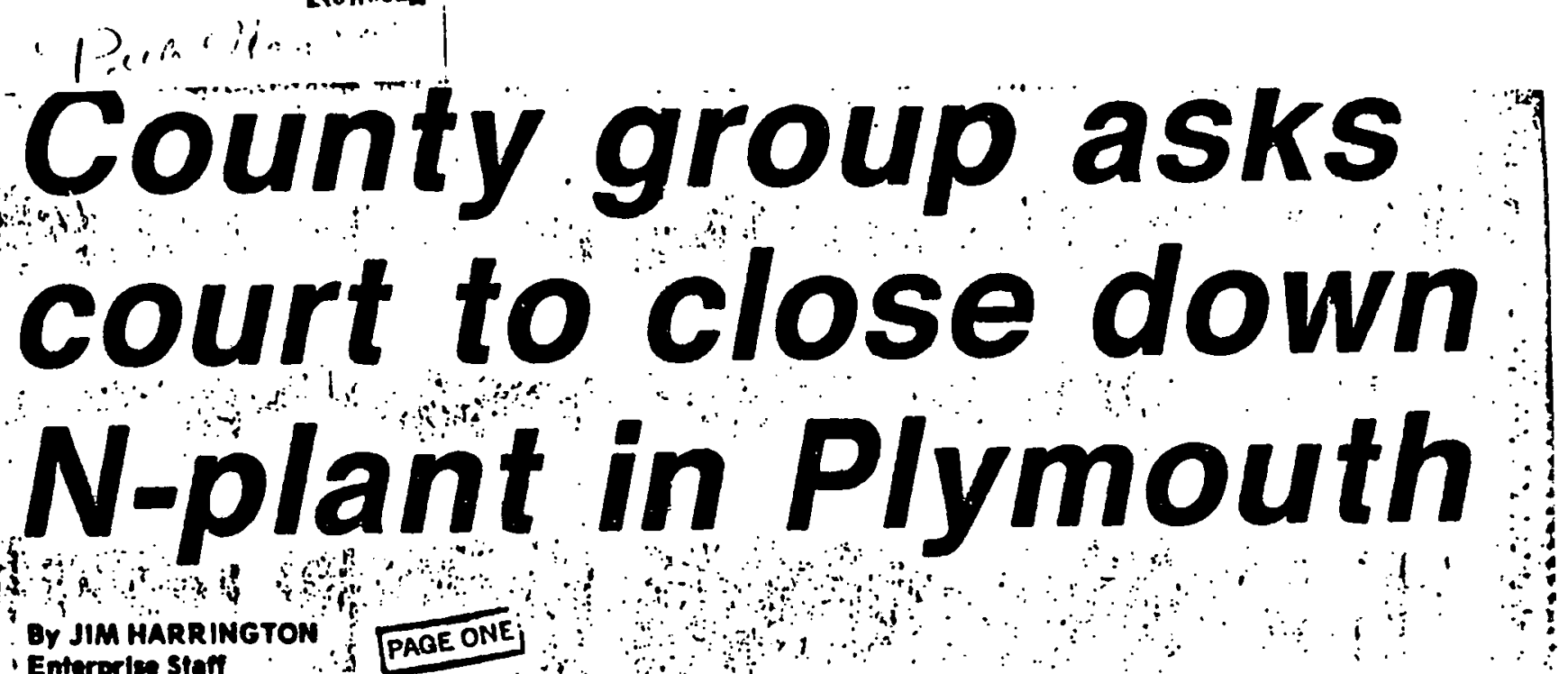

\section{Emverporice Ston}

Claiming that residents were "scared still, Iawyers lor the Plymquth County Nuclear Information

Committee Ine. asked Judge Henry Chmlelinshl Jr. In Brociton Superior Court Wednesday to close Boston Edl. con's Pllgrim nuclear plant until it could be operaled anfely.

The class action complaint in equity by PCNIC names Boston Edison Co. the tate Department of Public Health, state Civll Defense Agency and the Offlce of Emergency Preparedness, the state Department of Pub ilc Works, and the state Departmen. of Environmewtal Quality Engineering as defendants in the sult. Only Boston Edison was represented Wednesday.

The suit accuses the defendants of negligence, assault and battery, Intenthonal trespass, and eminent domain. The suit asts for a preliminary iniuneIton because of the following reasons:
- Until the plant can and will be operated fithout any emisslom of low evel radiction into the blosphere.

- Untll an evacuation plan for a 50 mile radlus aurrounding the plant has been adequately devised, Implemented. pubtished and tested by the Civil Defense Agency and the Orince of Emergency Preparedness.

- Untll the state Department of Public Health personnel are statlowed on the slte 24 hours per day to monitor the radioactlve emissions emanating from the plant.

- Untll the state Department of PubIle Health instltutes offsite monitoring of radiation in a sa-mile radius of the plant 24 houra per day.

- Until Nuclear Regulators Commission personnel are stationed in the control roon of the plant at all times durtng the plant's operation to safeguard ara ant human error and to en- sure that plant operating decislons are made in the public Interest rather than fust in Edison's interest.

- Untll adequate and safe provision has been made for storage of highly rediogctive spent fuel in a remote unpopulated site rather than Plymouth County.

- Untll the transportation of radiascllve waste is monitored on continuous basls over prevlously presy cribed routes and official escorts provided by the Department of Public Works and the Department of Public Health.

- Until the design of the plant conforms to all current Federal safety. standards.

- Until Boston Edison Co. notiftes all clizens within a so-mlle radlus of the plant that low-level radiation if dangerous to their health. BOSTON-See Page 12

$$
\text { - ... ... . . . . . . . . ... }
$$




\section{Boston Edison challenging jurisdiction of Plymouth suit}

$\therefore$ Continued From Pare One)

- Untl Edison agrees to and Imple ments a plan to rinance annual med. cal examinations for anyone $80 \mathrm{re}$ questing same within a lo-mlie radius of the plant.

Judge Chmlelinski sald he planned to do a lot of reading on the subject betore handing down a decision some day next week.

Robert K Grad III, who repre sented Boston Edison, suld that to comply with the demands of the clt1ten group would be Impossible to meet. He also challenged the right of a Supertor Court fudge to take action in the case becuase there was no legal authortty to reconsider the federal goverrment's' deciston allowino pli. grim 1 to operate. He sald only the U.S. Court of Appeals may review that dectsion.

Grad clted a list of court decisions that ruled the federal governmeot has exclustve power to relegate lssues related to radloactivity releases.

However, lawyers for the 600 -mem-

ber citizens group countered with the clatin that 1977 amendmenls to two tederal anti-pollution laws spectilcally allow the stale to limit radloactive re leases. . i

$\because \because \div ;$

The sult blames Edison for belng negligent by allowing radtoactlve particles to clrculate with the area.

The sult states that the plaintifis are in apprehension and fear for an

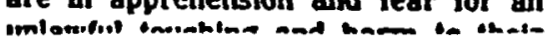

person by the discharge into the blow phere of lonlzing radiation resulting in assault and battery. . . . . . '.. . ....i. .

The plaintiffs in alleging intentional trespass say that radioactive emis. slons and fallout falls upon the plaintIf $8^{\prime}$ property and person.

In alleging eminent domaln, the plantirfs claim that as a direct and proximale result of Edison's release into the atr and water and onto the land of plaintilis of radio active pollu tants, plaintifls have been substan tially deprived of their beneficial us and enjoyment of their property. Th sult also alleges that propertles hay dropped in value because of the

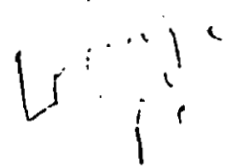




\section{Federal, State Officials Differ Over Possible Ill Effects of Radiation in Norton, Attleboro}

NORTON - II's gelling to be aboul a mile from Chartley as a reactor fuel a familiar tune since the ac. $\frac{\text { center. }}{\text { Martin. chief of the NItC's }}$ nuclear power plant, onfy now Safegunds Branch for this it's being ang about nuclear region, claims lo have narrowed waste discovered in a Norton the possiblities to two: Texas dump.

Instruments, considered the The song could be tibed "is it most likely sauree by Martin, or were inlenested in thinking up Chemicals Corporatlon bissed in tilles.

New Jersey.

According to Nuclear Other waste

According spectite isn. $t$ : According to being analyzed and compared Massechusetts public health alfeet George W. Swibel, ony if two tirms as well as from other you're standing on lop of it. But, inuclear manutacturers.

according to MIT nuclear TI merged with Metals and physicist Henry W. Kendall, yes, Controls Corporation which har and the contaminated dust could been producing fabricated fuet be "enormously loxic". if rods for naval and resentch inhaled. renclors since 1955. Production Even the source isn't really at the plant reportedly dropped known although it is believed to "a very small level" in 1966 that the nuclear wasles were according to company chmoed between 1951 to. 1908 spokesmari Lon Boncest

ecciden By Martin belleves. The The material found at the dump was privately owned and Norton dump consists of closed in 1969 at the death of the radium, uranlum oxide. opeator The sile is now owhed depleted uranium (with fuel $\therefore$ by Mrs, Isadore Shpack and is components removed and localed next to a playground and enriched uranium which is used
Martla raye his theory on how he matcrials came to end up in on the orion sile of Metals and controls had hecon contaminnted by spllage irom an outdoor he ihe fillered incinerator where low-lcvel radloactlve waste was burned of

- Iater, he said, construction on that site might have resulted in the contaminated soil being dug up and hauted to. the Norton dump.

Meanwhile, the staie has been conducting its own tests. With Swibel, a radiation scientist with the DPH. taking samples lor testing.

Swibel has stated that neither the material itself noc the dump generally presents an im. mediale health hazard "The pysical significance is zip. The prychologicil signiflcumes is something signiflcance is

lie added that inesin bulldozer tracks were cvident Friday indicating that the land was indicating that the iand was
Allteboro Landfill, Inc. property. a private, industria the past two months. The disturbance of the arre will mean a ncw serics a tostm can a new serles of testhe mine if any of mine if any of the nuclear wast In the meantimel Kendall In the meanime, Kendall. lounder of the Union of con. emed Scienilsts, clained that he hos seen the NRC repoft on bolh the Norton site and similar wasle found in a swamp adacent to the Finburg Field playgroumd in Alicboro and has concluded that the public should

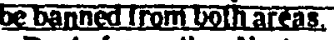

Dust from the Norton site. Kendall charged, brings a risk of lung cancer, birth defects and iming medical problems and similar medical problems and ceing "hol as a pistol."

On the ather hand Public On the nther hand. Public Health Commissioner Allred Fretle said in a statement last night, That Norton radiation levels are "solow" that a person would have to stand in one place for 17 hours before there would be cause for concern. 


\section{'No problem here' Officials clean site of alleged radioactive contamination in city}

BY LEO PELOQQUN Sun Chronicle Staff Writer

ATTLEBORO - Aided by a radiation scientist from the Massi Department of Public Health, Mayor Gerald Keane and severat city workers Monday removed radioactive soil discovered six months ago

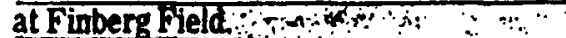

Worting for six houis in a constant rain, themen removed soil from four sites

in wooded area adiacent to the tield's anyone in here but radiation control baseball diamand. The soll filled four. 55- workers.:" :

gallon barrels.

The operation ended a radiation "problem" at the field that local, state, and federal offcials claim neper eristed.

"There's no danger bere;" : said radiation scientist George Swible. "If there was a danger, l'd be wearing. protective clothing and I wouldn't let in
SUN CHRONICLE

Attleboro, MA

June 5,1979
Torking with a sodium iodide crystal a device more sensitive to radiation than a Geiger counter - Swible scanned the soil and directed the worters to collect any that showed the slightest sign of radiation.

"If there is anything bere, I don't want It here." Swible said, but be emphasized several times that the radioactive. material; indentified montbs ago as natural radium, never posed a health hazard.

a

r.-Jince this Thee wille Island thing; this anti-nuke stute has gone crary," be said.

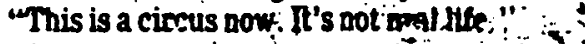
Strible said the highest readro if iom any of the earth collected was 1.15 millirems, far below the federal exposure limit of 500 millirems per year. The materials giving off the highest readings were a molten glass-like substance and some reddish-orange soil.

The soil is being stored at the city's highway department yard on Wall Street as city officials await word from the state heaith department, according to Civil 1 Sec LDEANE, Page 3 
SUN CHRONICLE

Attleboro, MA

June 5, 1979

SUN GAROILER

AmLBODOQ MA

D. 18,000

\section{JUN5 MTP Naglanil \\ Nervsciv}

\section{Keane: City $\because 1$ \\ Continued trom Page 1}

Defense Diréctor William Rollinson.

Keane, dressed in dungarees -and a raincoat and toting a'shovel, said be decided to bave the soil removed because of the publicity it had created last week in the Boston press.

"The local people didn't overreact to the situation, but I really thought that Boston and The Globe overdid it," be said. "So now, Attleboro doesn't bave a problem. It's gone."

Swible said the amount of radioactive substances actually contained in any one of the barrels of soil was "the size of two cigarettes."

He said, "You'd bave to get someone to stand on the exact spot where the substance was located for something like 170 hours before they would even get to the exposure level allowed by regulations."

The radiation was first detected at the field and at a former private landfill site in ty clean

Norton six months ago. Although state health officials and the Nuclear Regulatory Commission have assured local officials that no bealth hazard exists, an MIT professor who is the founder of an anti-nuke group has challeaged their position.

Walter Martin. chief of the NRC's Safeguards Branch for this region said a report on the source respopsible for dumping the material at the two sites is due in two weeks. He said the most likely candidates are Texas Instruments and the Metals and Controls Corp. It mersed with in 1959, and the D.E. Makepeace Company of Plainville, now owned by brgethand Minerals and Chemicals Corp. of New Jersey.

State Radiation Control Director Gerald Parker said a meeting with Norton officials is stated for next week to decide what to do about the landfill site. It is not yet clear who will pay for the clean-up operations at either site, he said. 
Ji. $1<1979$

Sul gipopiles:

Amingoid,

JUH 161978 Nown

Newectio

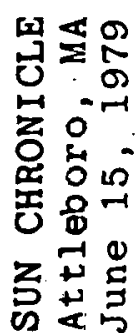

\section{CAnalysis shows Norton water 'well within standards'}

\section{By Lxo priopuivi}

cancroalcke Stat Witter

NORTON - Le Shask's dintings

waler still Jalh well within federal signs of radtosetivky, than it dis th Novemiber

That was the messige lederal and date adiation officiats had for the Boand at Selectmen Tharsday ss seletmen,

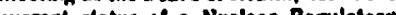
Commisston and state Depl. of Pubir Untom Rosd

mple radloaclive comlamination. The sample dump stte protitem dealt with quickly with

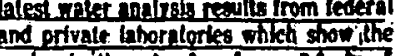

at the diserepancy th seasonal sample its. NAC ofikinls meaniwhle reflerated sos their dance or sover months ago hat the

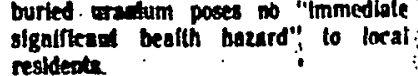
Sellipahe for "stirring op a monet's nes:t."
But. he wamed the lederal and state

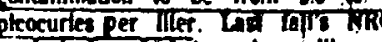
sale waler stamples released wednestay oflirtais. "I don't want to Ret any minre inom_Interex. showed doo otecourles pet informalion from Brown or Harvard or a a sis showed 0. pleocurtes por titer.

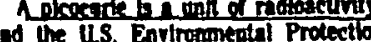
Ato the meeting were Attledoro Mayor Gerild J. Keane and Civil Delense Leos Lembardi. R-Easion. Brown Undverals restearines Robert Settpane, a Axencrisedindard tor enfe in is 15 picocurtes per liter.

Underany reseanciner Robert setlpane. a liter of well waler, but Parter sald he anyone else. Lraot lo sel informaltan

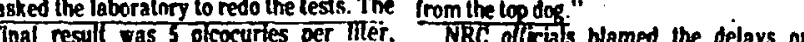

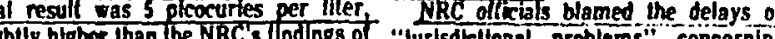

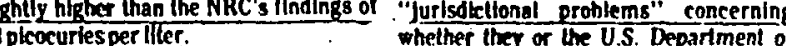
"We're going lo follow up agaln. If represedalive lrom Congresswoman

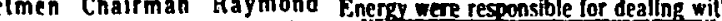
Patenaude sald he was satisfled with the the uranium and also sald they were to

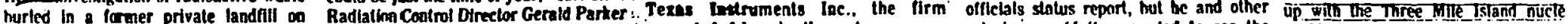
$-. . .$. selectmen satd they. wanled to sce the accioent

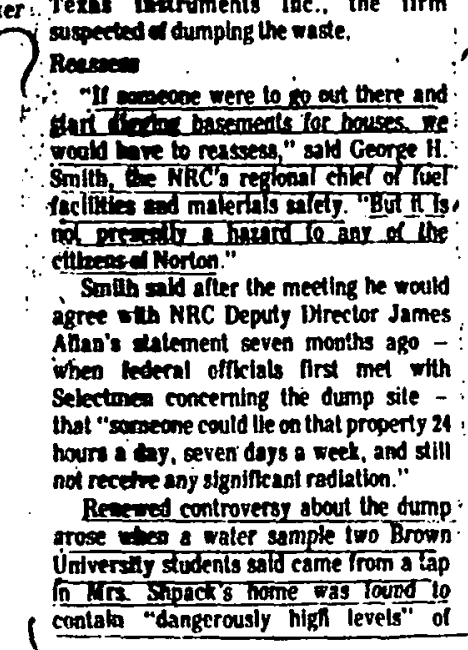


D. 18.000

\footnotetext{
JUN 111979 Nerstirn.
}

Decision on radium expected today

ATTLEBORO - City officials today to be outstde the cily." Kerne said. will decide when and where to dispose of radioactive soll collected last week from Finberg Field. The city will pay for the - cost - about 8200 - of the disposal, ac cording to Mayor Gerald Keane.

Mayor Gerald Keane Thursday discussed with the state Pepartment of Public. Health possible licensed disposal areas - In Natick, Worcester, and $\mathrm{New}$ Yotk - for the four 55-gallon barrels of soil which hive been stored ai the Highway Department yard on Wall Street.

"We're going to dispose of it and it has
State Radiation Costrol.Director

Gerald Parker sald it was up to city oflicials to choose the licensed disposal site.

"We're just giving !hem the information as to where they can take it," he explained. "There are several ways to dispose of It and it's up to them to decide which way they want to do th.

It is unclear presently wbether the state or the city will have to pay for the disposal.

The radioactive material, disco ered seven months ago at the public playground, was removed Tuestay by
Keane, a state radiation specialists, and several cily worters. Locál, state and (ederal officlals have repeatedly stated that the material emilted very low-level radiation and posed no health hazard.

In-a development with no apparent connection with the local radiation story Texas Instruments Inc. has Installed a telephone "hot:line" linking if with the Nuctear Regulatory Commission in Penísylvania.

Company spokeśman Lon Bonczek said two phones have been Installed as part of an NRC program which is an oulgrowth of the Three Mile Island nuclear accident.$$
\text { the Three Mile Island nuclear accident. }
$$

The program requires all firms that do huclear related work to install the lines, he said.

"Il has nothing to do with this local incident," he said. "The program was inillated because of the lack of com. munication during the Three Mile Island crisis.".

Texas Instrumenis this, week was named as the probable source of the radioactive waste found buried at a former private landfill located on Union Road in Norton. 
WORCESTER TELEGRAM

Worcester, MA

Nov. 30, 1979

\section{S- XSTIE?}

IIEs?:日

WORCESTER, MA.

a. SESt

NOV 30 :979

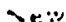

En!lun:d

Nicwocijp

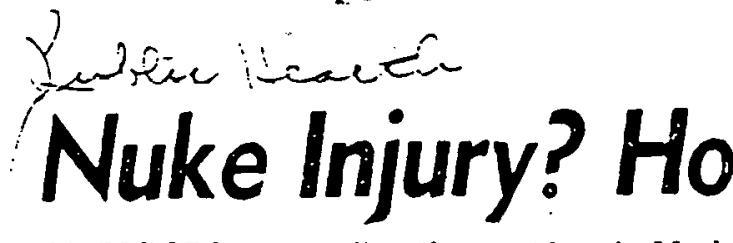

MARLBORO - A radioactive accident in Marlboro is unlikely: but if there is, Marlboro Hosplta will be ready to deal with patients who have been exposed to radiation.

William J. Belt of the state Department of Public Health conducted a program at the hospital this week to prepare emergency room staff for just such patients.

The biggest problem in treating patients who have been exposed to radiation is overcoming the fear the medical staff itsell may feel, he said.

"What happens frequently is everybody gets exciled about radiation and forgets about other health needs," he said.

Other injuries may be more serious than the exposure to radiation, but may not be treated quickly because people overreact when they learn about the radiation. he said.

Patients have been turned away from emergency rooms because the staff thinks the building will be contaminated, he said.

The program was offered to educate the staff in case there is such an emergency. said Rita Wright. director of education at the hospital and a member of the hospital's disaster committee.

"We have to dispel myths," she said.

Serious radiation emergencies are unilkely to be brought to the hospital because there are no industries in the area using large amounts of radiation, she said.

The biggest danger in Marlboro would come from accidents involving trucks transporting radioactive materials through the city or to the hospital itself for medical use, Bell said.

Regulatory agencies require hospitals to hold such meetings and to prepare emergency plans, he said.

The beginning of Bell's discussion sounded like a high school physics class as he explained the types, sources, uses and measurements of different kinds of radiation.

The correct treatment and handling of a radiation patient depends on what kind of radiation the person has been exposed to, he said.

Some types of radiation are like the light frum a nashlight, he'said. When it is on. it is there. and when it is off, it isn't. This is the kind of radiation used for X-rays, he said.

This is called irradiation and needs no treatment, he said.

Patients are conlaminaled when they are corvered with radioactive material. much ds they might be covered by chalk dust he sild.

Because the radiation is in a physical form, it can be transmitted by touching or hy air.

IC there is fime orecautions should be tatien not to touch a contaminated person, but contaminaliun should not stop r.edical persunnel from trealing other injurtes that demand atlention, he said bs: cause the contemination can be wiashid off later.

"There are lots of nice things you cun do." Bell said. but they shouldn't be dune if the persun could die from an untreated wound or lack of medical treatment in the meantime. 


\section{Nuclear waste: A jobs-and-environment problem}

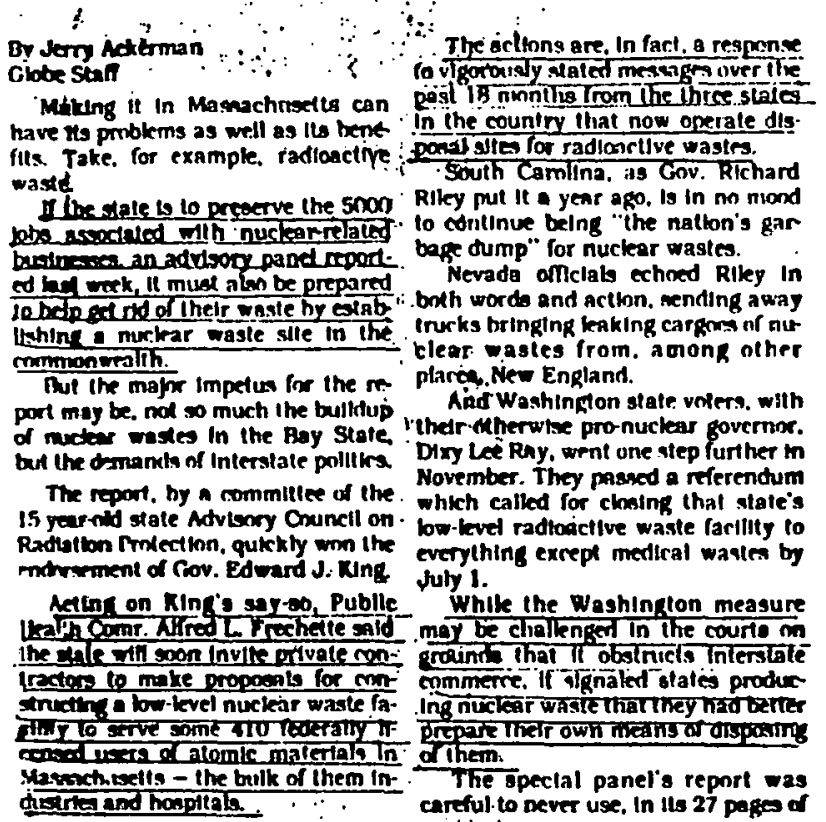

findings and rerommendaitons. the llanford slie be closed to out of state

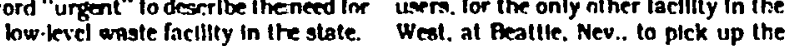
Any urecl waste faclitily in the state.

llkboin plant fabricates urantum stale have firther netuced thetr vof:

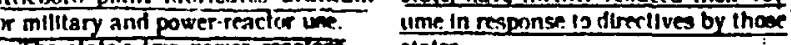
The stales lwo power reacios - stale Any commingoner of publh health, And in South Carolina Herward cald biter. "depends on what happens $G$. Shealy, direetne of the state bureau in the nther three states." mi whether of rndinhereal health. sald that siate's the now abandoned nuclear-waste drective to reduce the volume of dump at Wrst Valley. N.Y.. can be wasten its Bomwell faritity accepts

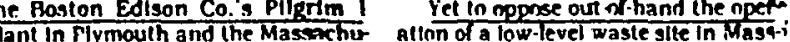

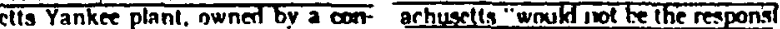
sorlum a 作

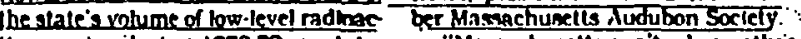
Ule vasics during 1978-79. contair Massachuselts cant rely on ather

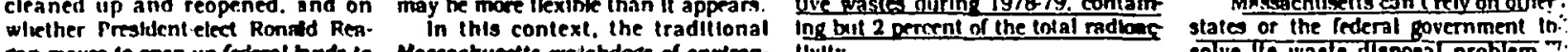

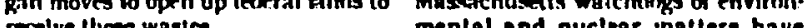

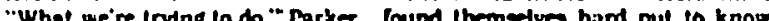

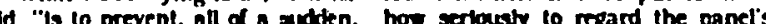
lie governors from the three klates recrommendaition. vily solve lis wasle disposal problem. the Which regularly ship their wastes to this gtele to try to snlue lls own prob::

withi existling slles from seteing to. "I don't really know how to take Rether and sayling. "No more." " II." sald letr Bernsteln, director of the

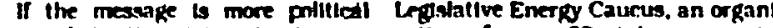
than subnantive. it is mere gong un- bilon of some 60 stale representaTeard in Washinglon sale. In cone. lives and sellators who have mank Lee Gronemeyer, In cturge of the clear they are skeptical of exponston Tansportation and waste manane of murtear power.

ment section of the state's Bepart- The bulk of bor-kvet radionctive

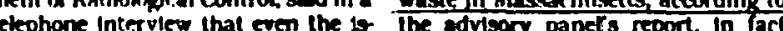
ter

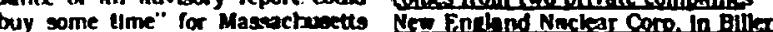
waste genesalors now using the hor tes and Bontoo. a manufacturer of 180 ivel dump in Hanfrud, Wash. It would be difincuin. shousd the and texas insiruments, Ine. whose 